PNL-6723

UC-510

$2 \%$

\title{
West Valley Glass Product \\ Qualification Durability Studies, \\ FY 1987-1988: Effects of \\ Composition, Redox State, Thermal History, and Groundwater
}
M. A. H. Reimus
G. B. Mellinger
G. F. Piepel
L. R. Bunnell

November 1988

Prepared for the U.S. Department of Energy under Contract DE-AC06-76RLO 1830

Pacific Northwest Laboratory Operated for the U.S. Department of Energy by Battelle Memorial Institute 


\title{
DISCLAIMER
}

This report was prepared as an account of work sponsored by an agency of the United States Government. Neither the United States Government nor any agency thereof, nor Battelle Memorial Institute, nor any or theif employees, makes any warranty, expressed or implied, or assumes any legal liability or responsibility for the accuracy, completeness, or usefulnes\$ of any information, apparatus, product, or process disclosed, or represents that its use would not infringe privately owned rights. Reference herein to any specific commercial product, process, or service by trade name, trademark, manufacturer, or otherwise does not necessarily constitute or imply its endorsement, recommendation, or favoring by the United States Government or any agency thereof, or Battelle Memorial Institute. The views and opinions of authors expressed herein do not necessarily state or reflect those of the United States Government or any agency thereof.

\author{
PACIFIC NORTHWEST LABORATORY \\ operated by \\ BATTELLE MEMORIAL INSTITUTE \\ for the \\ UNITED STATES DEPARTMENT OF ENERGY \\ under Contract DE-AC06-76RLO 1830
}

\begin{tabular}{|c|c|}
\hline \multicolumn{2}{|c|}{ Printed in the United State's of America } \\
\hline \multicolumn{2}{|c|}{ Available from } \\
\hline \multicolumn{2}{|c|}{ National Technical Information Service } \\
\hline \multicolumn{2}{|c|}{ Unted SIales Department of Commerct } \\
\hline \multicolumn{2}{|c|}{5285 Porl Royal Road } \\
\hline \multicolumn{2}{|c|}{ Springrield, Virginia 22161} \\
\hline \multicolumn{2}{|c|}{ NTIS Price Codes } \\
\hline \multicolumn{2}{|c|}{ Mic rofiche AOI } \\
\hline \multicolumn{2}{|c|}{ Printed Copy } \\
\hline & Price \\
\hline Pages & Codes \\
\hline $001-025$ & A02 \\
\hline $026-050$ & $\mathrm{~A} 03$ \\
\hline $051-075$ & $A 04$ \\
\hline 076.100 & A05 \\
\hline $101-125$ & $A 06$ \\
\hline $126-150$ & $A 07$ \\
\hline $151 \cdot 175$ & $\mathrm{~A} 08$ \\
\hline $176-200$ & $\mathrm{~A} 09$ \\
\hline $201-225$ & A10 \\
\hline $226-250$ & AlT \\
\hline $251-27.5$ & A12 \\
\hline $276-300$ & A13 \\
\hline
\end{tabular}


PNL-6723

UC -510

WEST VALLEY GLASS PRODUCT QUALIFICATION

DURABILITY STUDIES, FY 1987-1988:

EFFECTS OF COMPOSITION, REDOX STATE, THERMAL HISTORY, AND GROUNDWATER

M. A. H. Reimus

G. F. Piepel

G. B. Mellinger

L. R. Bunnell

November 1988

Prepared for the U.S. Department of Energy

under Contract DE-ACO6-76RLO 1830

Pacific Northwest Laboratory

Richland, Washington 99352 



\section{ABSTRACT}

The product qualification subtask of the West Valley Support Task (WVST) at Pacific Northwest Laboratory (PNL) provides support for the waste form qualification efforts at West valley Nuclear Services Co. Testing is being conducted to determine waste form chemical durability in support of these efforts. The effects of composition, ferrous/ferric ratio (redox state), thermal history, and groundwater are being investigated. Glasses were tested using modified Materials Characterization Center (MCC) -3 and MCC-1 test methods. Results obtained in fiscal years (FY) 1987 and 1988 are presented here. 


\section{SUMMARY}

The product qualification subtask of the West Valley Support Task (WVST) at Pacific Northwest Laboratory (PNL) provides support for the waste form qualification efforts at West Valley Nuclear Services Co. Testing is being conducted to determine waste form chemical durability in support of these efforts. The effects of composition, ferrous/ferric ratio (redox state), thermal history, and groundwater are being investigated. Results obtained in fiscal years (FY) 1987 and 1988 are presented here.

Glasses were tested using modified Materials Characterization Center (MCC) -3 and MCC-1 test methods. Replicates were run for each glass composition. These 7- and 28-day tests are useful for initial studies, and applicable to waste form qualification; however, tests of longer duration are needed to determine the long-term durability of these glasses.

During FY 1987, two sets of compositional variation glasses were fabricated and leach tested with the 7-day MCC-3 test to determine the effect of composition on waste glass chemical durability. The first set of glasses consisted of eight variations of West Valley Ceramic Melter reference glass WVCM-47, while the second set consisted of 16 variations of reference glass WVCM-50. The set of eight glasses was selected to investigate the effects of specific single-component and other variations (from WVCM-47) of interest. The set of $16 \mathrm{glasses}$ was selected using statistical experimental design techniques so as to provide the most information about the effect of varying composition within the specified compositional variation region. Boron releases of the glasses ranged from $34 \%$ above to $29 \%$ below the WVCM- 50 value. A linear mixture model fit the data very well, and demonstrated that varying composition has a statistically significant effect on chemical durability (as quantified by boron release in the 7-day MCC-3 leach test). The fitted linear mixture model can be used to predict the effects on durability of varying the composition within the region investigated.

During FY 1988 , sixteen glasses were fabricated based on statistically selected compositional variations of the WV-B801 composition. The glasses were examined for the presence of secondary (crystalline) phases, and the 
glass compositions were analyzed. The glasses' chemical durabilities were characterized using 28-day MCC-1, and 7- and 28-day MCC-3 leach tests.

All of the glasses tested had observed normalized release rates below the Waste Acceptance Preliminary Specifications (WAPS). The applicable specification states that the normalized release rates of $\mathrm{Na}, \mathrm{Si}, \mathrm{B}, \mathrm{U}$, and Cs must be below $1 \mathrm{~g} / \mathrm{m}^{2}$-day or $28 \mathrm{~g} / \mathrm{m}^{2}$ in a 28 -day MCC-1 test in dejonized water at $90^{\circ} \mathrm{C}$. However, the $95 \%$ upper confidence limit of the release over the compositional region investigated is $29.3 \mathrm{~g} / \mathrm{m}^{2}$, which accounts for shortand long-term within-laboratory variability in the leach testing and chemical analysis procedures. The $95 \%$ upper confidence limit increases to $41.1 \mathrm{~g} / \mathrm{m}^{2}$ when including a $20 \%$ lab-to-lab variability. Both of these latter values are above the proposed limit. Rather than concluding that the compositional region is too large, it may be that the 1 imit needs to be reassessed. It is not clear whether the limit was suggested with statistical characterization of chemical durability in mind. Several options including a smaller composition region, need for statistical variability consideration, reduction in analytical variability, investigation of an additional composition region, or reassessment of the proposed limit should be further investigated. It is clear that lab-to-lab and within-lab uncertainties should not be ignored, either in characterizing the chemical durability of a region of glass compositions, or in the specification of an acceptance criterion.

The results of the microstructural characterization of the sixteen WV-8801 glass variations indicate that the composition changes within the region being characterized by PNL do not produce marked changes in the nonglass phases to be found in these glasses. Though some glass-to-glass variations occur, differences are subtle and the total amount of crystalline materiat is quite smal1. The formation of these crystalline phases during melter processing could cause sludge formation in the melter. Further study of the formation of these crystals should be undertaken.

Four glasses with identical composition (WVCM-50) but with different redox states were tested to determine the effect of redox state on the chemical durability of the reference glass. Analyses of the normalized elemental 
releases from the glasses indicate that redox state does not have a statistically significant effect on the chemical durability.

West Valley reference glass (WVCM-50) was subjected to two types of heat treatment, then leach tested to determine the effects of thermal history on glass chemical durability. Two types of heat treatment were used: slow cooling--simulating glass canister cooling, and isothermal. Cubic spineltype crystals $\left[(\mathrm{Fe}, \mathrm{Ni})(\mathrm{Cr}, \mathrm{Fe})_{2} \mathrm{O}_{4}\right]$ and $\mathrm{ThO}_{2}$ crystals were observed in all treated specimens. Hematite-type crystals $\left[(\mathrm{Cr}, \mathrm{Fe})_{2} \mathrm{O}_{3}\right]$ and $\mathrm{Ru}$ inclusions were observed in most of the specimens. Rapidly cooled glass specimens were more chemically durable than the more slowly cooled specimens. Based on B release, the slow-cool heat treatments caused a maximum decrease in durability of $40 \%$. The isothermal heat treatments caused a maximum decrease of $100 \%$. Isothermal treatments at $725^{\circ} \mathrm{C}$ for $\geq 12 \mathrm{~h}$ caused the most consistent decrease in durability, at $44 \%$.

West Valley reference glass (WVCM-50) was tested in four groundwaters to determine the effect of groundwater on chemical durability. The four groundwaters tested were PBBI and PBB3 (bedded salt site groundwaters), J-13 well water (a tuff groundwater), and GR-4 (a basalt groundwater). Groundwater type was found to have a definite effect on chemical durability, causing up to a factor of 5 increase in durability, based on $B$ release, as compared to durability in DIW. The 7-day $B$ releases from the glass were $0.045 \mathrm{~g} / \mathrm{m}^{2}$ in PBB1, $0.060 \mathrm{~g} / \mathrm{m}^{2}$ in PBB3, $0.076 \mathrm{~g} / \mathrm{m}^{2}$ in $\mathrm{J}-13$ water, $0.092 \mathrm{~g} / \mathrm{m}^{2}$ in $G R-4$, and $0.209 \mathrm{~g} / \mathrm{m}^{2}$ in deionized water. 


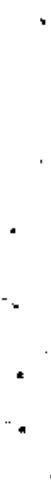




\section{ACKNOWLEDGMENTS}

The authors wish to acknowledge the technical efforts and contributions of the following individuals: John Carroll and Wayne Ross for programmatic guidance, Bill Gerry and Mike Schweiger for glass fabrication, leach testing, and equipment and lab maintenance, Frank Hara and his staff for timely analytical services, Elmer Shade and Valerie Eliason for glass heat treatments, Daryl Parks for glass metallography, Homer Kissinger and Harold Kjarmo for XRD analyses, and Jim Coleman for SEM/EDX analyses. In addition, we thank Terri Gilbride for technical editing and DeDe Johnson for completing the word processing. 


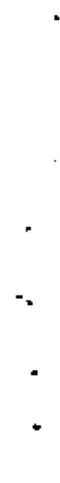




\section{CONTENTS}

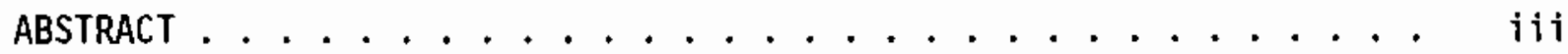

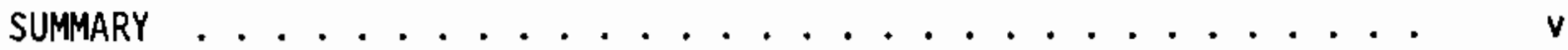

ACKNOWLEDGMENTS ......................... ix

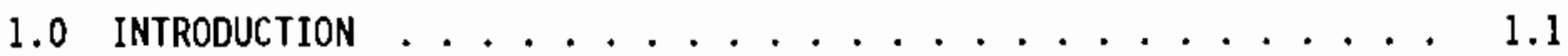

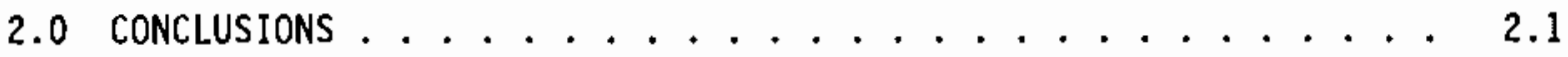

3.0 EXPERIMENTAL METHODS AND APPROACH ............. 3.1

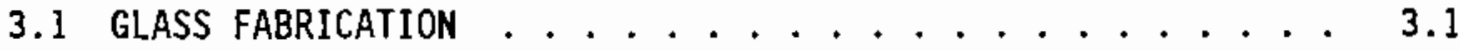

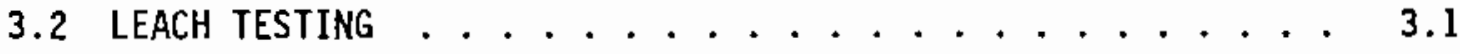

3.2.1 Modified MCC-3 Leach Test Method. ......... 3.1

3.2.2 MCC-1 Leach Test Method ............ 3.4

3.3 GLASS AND SOLUTION ANALYSES . . . . . . . . . . . . 3.5

3.4 COMPOSITION REGIONS--FY $1987 \ldots \ldots . \ldots . \ldots$

3.4.1 First Set of Glasses . . . . . . . . . 3.7

3.4.2 Second Set of Glasses . . . . . . . . . . 3.7

3.5 COMPOSITION REGION--FY $1988 \ldots \ldots \ldots$

3.6 GLASS REDOX ADJUSTMENT . . . . . . . . . . . . . 3.14

3.7 GLASS HEAT TREATMENTS $\ldots \ldots \ldots \ldots \ldots . \ldots . \ldots . \ldots . \ldots$

3.7.1 Simulated Canister Cooling ......... 3.16

3.7.2 Isothermal Heat Treatments . . . . . . . . 3.21

3.8 GROUNDWATER LEACH TESTING . . . . . . . . . 3.23

3.8.1 Groundwater Descriptions . . . . . . . 3.25

3.8.2 Leach Testing and B 1 ank Correction ....... 3.28

4.0 RESULTS AND DISCUSSION . . . . . . . . . . . . 4.1

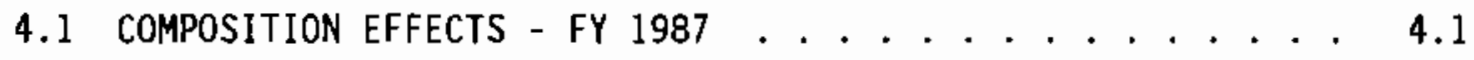


4.1.1 First Set of FY 1987 Glasses--DG-WVI

Through DG-WV8 ................ 4.1

4.1.2 Second Set of FY 1987 Glasses--DG-WV15

Through DG-WV30 ............... 4.4

4.2 EMPIRICAL MODELING AND STATISTICAL ANALYSIS OF FY 1987

NORMALIZED BORON RELEASE DATA ............ 4.11

4.2.1 Empirical Models for Normalized Boron Release . . . . 4.11

4.2.2 Boron Release Data Uncertainty . . . . . . . 4.15

4.2.3 Confidence and Tolerance Bands ......... 4.16

4.2.4 Application of Confidence and Tolerance Bands . . . 4.16

4.3 COMPOSITION EFFECTS - FY $1988 \ldots \ldots \ldots \ldots . \ldots . \ldots . \ldots$

4.4 STATISTICAL ANALYSIS AND EMPIRICAL MODELING OF FY 1988
NORMALIZED RELEASE DATA . . . . . . . . . . 4.22

4.4.1 Linear Mixture Models Fit to Normalized

Boron Release Data . . . . . . . . . . 4.24

4.4.2 Component Effects Plots ........... 4.26

4.4.3 Confidence and Tolerance Statements About Normalized Boron Release Over the Composition Region..... 4.26

4.5 MICROSTRUCTURE OF FY 1988 SET OF GLASSES . . . . . . . 4.31

4.6 GLASS REDOX ADJUSTMENT EFFECTS . . . . . . . . . . 4.36

4.7 THERMAL HISTORY EFFECTS . . . . . . . . . . 4.38

4.7.1 Simulated Canister Cooling .......... 4.38

4.7.2 Isothermal Heat Treatment . . . . . . . . . 4.42

4.8 GROUNDWATER EFFECTS . . . . . . . . . . . 4.46

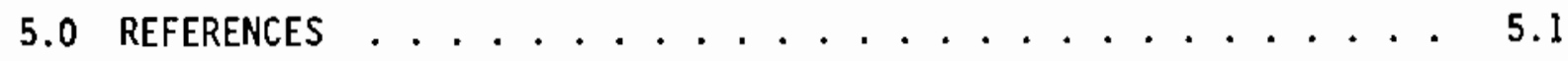

APPENDIX A - AVERAGE NORMALIZED MASS RELEASES OF DG-WV1 . . . . . A.1

APPENDIX B - FORMULAS FOR CONFIDENCE AND TOLERANCE BANDS . . . . B B.1

APPENDIX C - SHORT-TERM, LONG-TERM, AND LAB-TO-LAB VARIATIONS IN GLASS ANALYSES, LEACH TESTING, AND LEACHATE ANALYSES ..... C.1 
APPENDIX D - ESTIMATES OF SHORT- AND LONG-TERM WITHIN-LAB UNCERTAINTIES BASED ON REPEAT GLASS ANALYSES, REPEAT LEACHATE ANALYSES,

AND REPEAT LEACH TESTS ............. D. . . 1 


\section{FIGURES}

3.1 Sample HT-S-1 Cooling History . . . . . . . . . . . . . . . 3.17

3.2 Sample HT-S-2 Cooling History . . . . . . . . . . . . 3.17

3.3 Sample HT-S-3 Cooling History . . . . . . . . . . . 3.18

3.4 Sample HT-S-4 Cooling History . . . . . . . . . . . 3.18

3.5 Sample HT-S-5 Cooling History . . . . . . . . . . . . 3.19

3.6 Sample HT-S-6 Cooling History . . . . . . . . . . . . 3.19

3.7 Thermocouple Locations in Canister TC-18 . . . . . . . 3.20

3.8 Thermocouple Locations in Canister TC-23 . . . . . . . 3.20

4.1 Comparison of $S i$ and $B$ Normal ized Mass Releases
from DG-WV1 Through DG-WVB (7-day MCC-3) . . . . . . . 4.2

4.2 Comparison of $\mathrm{Si}$ and $\mathrm{B}$ Normalized Mass Releases from DG-WV1 Through DG-WVB (28-day MCC-1) . . . . . . . . 4.4

4.3 Comparison of Si and B Normalized Mass Releases of Least Durable of Second Set of FY 1987 Compositional Variabitity Glasses . . . 4.6

4.4 Comparison of Si and B Normalized Mass Releases of Most Durable of Second Set of FY 1987 Compositional Variability Glasses . .

4.5 Comparison of B and Si Normalized Mass Releases of Least Durable of Second Set of FY 1987 Compositional Variability Glasses . . .

4.6 Comparison of B and Si Normalized Mass Releases of Most Durable of Second Set of FY 1987 Compositional Variability Giasses . . .

4.7 Component Effects Plot for Normalized Boron Release from Glasses in the WVCM-50-Based Compositional Region Tested with the 7-day Modified MCC-3 Test . . . . . . . . . . . .

4.8 Component Effects Plot for Normalized Silicon Release from Glasses in the WVCM-50-Based Compositional Region Tested with the 7-day Modified MCC-3 Test . . . . . . . . . . . 4.14

4.9 Comparison of B and Si Average Normalized Releases of Most Durable of FY 1988 Compositional Variability Glasses . . . . .

4.10 Comparison of B and Si Average Normalized Releases of Least Durable of FY 1988 Compositional Variability Glasses .... . 
4.11 Component Effects Plot for Normalized Boron Release from Glasses in the WV-8801-Based Compositional Region Tested with the 28-Day MCC-1 Test ...............

4.12 Component Effects Plot for Normalized Boron Release from Glasses in the WV-8801-Based Compositional Region Tested with the 7-Day MCC-3 Test ............... 4.28

4.13 Optica] Micrograph of DG-WV33 . . . . . . . . . . . 4.34

4.14 SEM Micrograph of DG-WV44 Showing Metallic Surrounded by Acicular Crystals, Plus Spheroids in Surrounding GTass . . . 4.35

4.15 SEM Micrograph of DG-WV47 Showing Abundance of Metallics Surrounded by Acicular Crystals ............ 4.35

4.16 Comparison of Silicon and Boron Normalized Mass Releases from Redox-Adjusted Glasses .............. . 4.38

4.17 Comparison of Silicon and Boron Normalized Mass Releases from Slow-Cool Heat-Treated Glasses . . . . . . . . . . . 4.41

4.18 Time-Temperature-Transformation Diagram for B Releases from Isothermally Heat-Treated Reference Glass . . . . . . . 4.47

4.19 Comparison of B and Si Normalized Mass Releases from Reference Glass in Different Groundwaters . . . . . . . . . . . . . 


\section{IABLES}

3.1 Glass 0xide Sources .................. 3.2

3.2 Composition of West Valley Reference Glasses WVCM-47 and WVCM-50 ................. 3.6

3.3 Compositions of First Set of FY 1987 Compositional Variability Glasses, wt\% ............. 3.8

3.4 Definition of Compositional Variation Region Based on WVCM-50 ................ . 3.9

3.5 Compositions of Second Set of FY 1987 Compositional Variability G1asses: DG-WV15 through DG-WV30, wt\% ......... 3.10

3.6 Definition of Compositional Variation Region Based on WV-8801, wt\% ................. 3.12

3.7 Target and "As Analyzed" Compositions for the 16 WV-8801 Compositional Variation Glasses . . . . . . . . . . . 3.13

3.8 Compositions of Redox Adjusted Glasses . . . . . . . . . 3.15

$3.9 \mathrm{Fe}^{2+} / 3+$ Ratios of $\mathrm{Glasses}$ Tested . . . . . . . . . . 3.16

3.10 Compositions of Slow Coot Heat Treated Glasses . . . . . . . 3.22

3.11 Isothermal Heat Treatment Test Matrix . . . . . . . . . . 3.23

3.12 Compositions of DG-WV31 Batches, wt\% ......... 3.24

3.13 Composition of J-13 Well Water--Tuff Groundwater Used in Groundwater Study ............... 3.25

3.14 Composition of PBB1 Brine Used in Groundwater Study . . . . . . . 3.26

3.15 Composition of PBB3 Brine Used in Groundwater Study . . . . . . . 3.26

3.16 Composition of GR-4 - Basalt Groundwater Used in Groundwater Study .................... 3.27

3.17 Composition of West Valley Reference Glass Used in Groundwater Effects Study, wt\% ............

4.1 Average Normalized Mass Releases of G1asses DG-WV1 Through DG-WV8

4.2 Average Normalized Mass Releases of G1asses DG-WV1 Through DG-WV8 
4.3 Average Normalized Mass Releases of Glasses DG-WV15

Through DG-WV30 ................... 4.5

4.4 Average Normalized Mass Releases of Glasses DG-WV15 Through

DG-WV30 . . . . . . . . . . . . . . 4.8

4.5 Comparison of Observed Normalized Boron Release Values to

Predicted Values and Prediction Intervals . . . . . . . . 4.13

4.6 Average Normalized Releases of Glasses DG-WV33 Through

DG-WV48 . . . . . . . . . . . . . . 4.18

4.7 Average Normalized Releases of Glasses DG-WV33 Through

DG-WV58 . . . . . . . . . . . . . . . 4.19

4.8 Average Normalized Releases of Glasses DG-WV33 Through

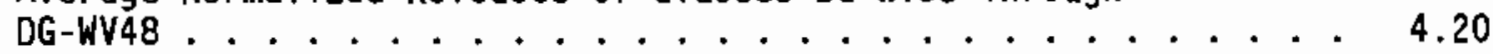

4.9 Relative Standard Deviations and Degrees of Freedom Used

as the Basis for the Confidence and Tolerance Statements . . . 4.25

4.10 Confidence and Tolerance Band Statements for Maximum

Normalized Boron Releases Over the WV-8801-Based

Compositional Variation Region ............ 4.30

4.11 Optica] and SEM Microscopy Observations of Glasses

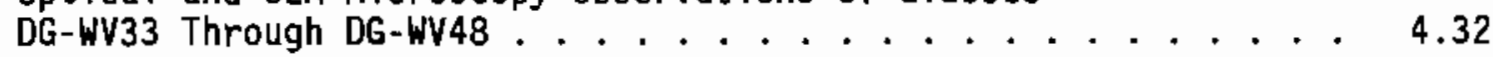

4.12 Average Normalized Elemental Mass Releases of

Redox Adjusted Glasses . . . . . . . . . . . . 4.37

4.13 Amounts of Crystals Identified by XRD in Heat-Treated Glasses ............... . 4.39

4.14 Average Normalized Elemental Mass Releases of Glass Heat-Treated with Simulated Canister Cooling Rates . . . . . 4.40

4.15 Amounts of Crystals Identified by XRD in Heat Treated Glasses Relative to Amounts in Standard Specimen .......... 4.43

4.16 Average Normalized Mass Releases of Specimens Isothermally Treated at 500 and $600^{\circ} \mathrm{C} \ldots \ldots . . \ldots 4.44$

4.17 Average Normalized Mass Releases of Specimens Isothermally Treated at $725^{\circ} \mathrm{C} \ldots \ldots . \ldots . \ldots 4 . \ldots$

4.18 Average Normalized Mass Releases of Specimens Isothermally Treated at 800 and $900^{\circ} \mathrm{C} \ldots \ldots . . . .$. 
4.19 Average Normalized Mass Releases of West Valley Reference Glass in PBB1, PBB3, Reference Tuff and Basa1t Groundwaters and DIW........................... 48 


\subsection{INTRODUCTION}

The Product Qualification Subtask of the West Valley Support Task (WVST) at Pacific Northwest Laboratory (PNL) provides support for the waste form qualification efforts for the West Valley Demonstration Project (WVDP) at West Valley, New York. West Valley was the site of the Nuclear Fuel Services commercial nuclear fuel reprocessing facility until operations terminated in 1972. The State of New York then assumed responsibility for the high-leve] waste (HLW) stored in underground tanks at the site. The Department of Energy (DOE) is assisting, through the WVDP, in retrieving and solidifying these wastes. The site contractor for the WVDP is West Valley Nuclear Services Co., Inc. (WVNS).

The overall objective of PNL's WVST is to provide the technical support. required by the WVDP, including the transfer of DOE-developed HLW treatment technology. Specific objectives include 1) providing characterization data that support the West Valley glass waste form acceptability and 2) assisting WWS with the technology and equipment required to successfully vitrify the high-level waste.

Testing is being conducted by PNL's Product Qualification subtask to determine waste form chemical durability in support of West Valley's waste form qualification efforts. The effects of composition, ferrous/ferric ratio (redox state), heat treatment, and groundwater are being investigated. The results of these studies will he]p determine the limits under which WVNS can operate their melter system to produce glass that is durable enough to meet repository acceptance specifications and provide data needed for demonstrating compliance with these specifications. The chemical durability of the glass within specified composition variation regions was studied with the aid of statistical techniques during FY 1987 and 1988. Studies to determine the effects of redox state, thermal history, and groundwater were conducted during FY 1987. Results obtained from studies conducted during FY 1987 and 1988 are presented here. 


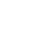

.,

$\cdot$ 


\subsection{CONCLUSIONS}

Based on the results of the studies conducted during FY 1987 and 1988, the following conclusions were reached:

- The linear mixture models developed in FY 1987 may be used to predict how varying composition affects the durability of the reference $\mathrm{glasses}$ (WVCM-47 and -50 ) within the defined composition region.

- Leach test results indicate that the addition of $0.1 \mathrm{wt} \%$ total noble metal oxides does not significantly affect the reference glass durability (FY 1987).

- The linear mixture models developed during FY 1988 may be used to predict how varying composition affects the durability of reference glass WV-8801 within the defined composition region studied.

- The chemical durability of the target composition (WVCM-50 with 1 wt\% less $\mathrm{B}_{2} \mathrm{O}_{3}$ and $1 \mathrm{wt} \%$ more $\mathrm{K}_{2} \mathrm{O}$ ) was not strongly affected by the variation of $\mathrm{glass}$ redox state over the $\mathrm{Fe}^{2+} / \mathrm{Fe}^{3+}$ range of 0.07 to 0.42 . The $\mathrm{pH}$ of the leachate increased with increasing $\mathrm{Fe}^{2+} /$ $\mathrm{Fe}^{3+}$ ratio; however, this rise is probably due to $\mathrm{Fe}^{2+}$ oxidation in the Teachate (FY 1987).

- Certain isothermal heat treatments can cause up to a twofold decrease in the chemical durability of the target composition. However, heat treatments that simulate anticipated canister cooling conditions have no substantial effects on the chemical durability of this glass (FY 1987).

- The target composition is more durable in groundwater than in deionized water by up to a factor of 5 based on $B$ release (FY 1987).

- All glasses tested during FY 1988 had observed normalized B release rates below $1 \mathrm{~g} / \mathrm{m}^{2}$.day or $28 \mathrm{~g} / \mathrm{m}^{2}$ based on the 28 -day MCC-1 tests. However, the $95 \%$ upper confidence 1 imit on maximum $B$ release over the composition region tested in FY 1988 is $29.3 \mathrm{~g} / \mathrm{m}^{2}$ (28-day 
MCC $-1,90^{\circ} \mathrm{C}$, deaerated DIW) which accounts for short- and long-term within-7aboratory variability and $41.1 \mathrm{~g} / \mathrm{m}^{2}$ when including $20 \% 1 \mathrm{ab}-$ to-lab variability.

- The normalized release 1 imit of $1 \mathrm{~g} / \mathrm{m}^{\hat{2}}$.day (28-day $\mathrm{MCC}-190^{\circ} \mathrm{C}$, DIW, leach test conditions) suggested by the Nevada Nuclear Waste Storage Investigations Project needs to be assessed with the statistical characterization of chemical durability in mind (FY 1988).

- Lab-to-1ab and within-lab statistical uncertainties should not be ignored, either in characterizing the chemical durability of a glass composition region, or in selecting an acceptance criterion (FY 1988).

- Crystalline phases were noted in some of the glasses and are a processing concern because of the potential for sludge buildup in the melter. Further study of the formation of these crystalline phases should be undertaken. 


\subsection{EXPERIMENTAL METHODS AND APPROACH}

\subsection{GLASS FABRICATION}

All glasses tested were prepared according to specific target oxide compositions with source chemicals consisting mainly of carbonates and oxides. The source chemicals used are listed in Table 3.1. The sources of the "waste mix" oxides indicated in Table 3.1, were blended together to form a waste mix component. The individual glasses were batched with this waste mix and other oxide sources as appropriate for their target compositions. The $U$ and Th oxide sources were added to the batches at a later time. All batches were blended prior to melting to insure homogeneity. When oxidation state control was required, a small amount of graphite was added to the batch during the melting process.

Each batch was melted at its approximate T100P (temperature at which the glass viscosity is 100 poise) for 1 hour in a Pt crucible with one melt stir at 30-min elapsed time. The glass was air quenched, cooled to room temperature, then ground to approximate $-100+200$ mesh size in a disk mill. The $U$ and Th oxide sources were added to this powdered glass, the mixture was briefly agitated, and then was added to a ceramic crucible. When fabricating a redox-adjusted glass, a small amount of graphite was added to the mixture at this point. The mixture was then melted at its approximate T100P for $2 \mathrm{~h}$. The glass was stirred at 30 -min intervals.

\subsection{LEACH TESTING}

All glasses were tested with a modified MCC-3 (MCC 1986) leach test method. A number of glasses were tested with the MCC-1 leach test method (MCC 1986). Brief descriptions of these methods follow.

\subsubsection{Modified MCC-3 Leach Test Method}

Glass specimens were ground in an automatic mortar and pestle and then sieved to obtain $-100+200$ mesh powders. These specimens were placed in 
TABLE 3.1. Glass 0xide Sources

\begin{tabular}{|c|c|c|}
\hline & Glass 0xide & Oxide Source \\
\hline & $\begin{array}{l}\mathrm{Al}_{2} \mathrm{O}_{3} \\
\mathrm{~B}_{2} \mathrm{O}_{3} \\
\mathrm{Fe}_{2} \mathrm{O}_{3} \\
\mathrm{MnO}_{2}{ }^{\mathrm{*}} \\
\mathrm{P}_{2} \mathrm{O}_{5} \\
\mathrm{PdO}_{2} \\
\mathrm{RhO}_{2} \\
\mathrm{RuO}_{2} \\
\mathrm{SiO}_{2}\end{array}$ & $\begin{array}{l}\mathrm{Al}_{2} \mathrm{O}_{3} \\
\mathrm{H}_{3} \mathrm{BO}_{3} \\
\mathrm{Fe}_{2} \mathrm{O}_{3} \\
\mathrm{MnO}_{2} \\
\left(\mathrm{NH}_{4}\right)_{2} \mathrm{HPO}_{4} \\
\mathrm{PdO} \\
\mathrm{Rh}_{2} \mathrm{O}_{3} \\
\mathrm{RuO}_{2} \\
\mathrm{SiO}_{2}\end{array}$ \\
\hline Actinides & $\begin{array}{l}\mathrm{ThO}_{2} \\
\mathrm{UO}_{2}\end{array}$ & $\begin{array}{l}\mathrm{ThO}_{2} \\
\mathrm{UO}_{2}\end{array}$ \\
\hline $\begin{array}{l}\text { Alkal ine } \\
\text { Earths }\end{array}$ & $\begin{array}{l}\mathrm{BaO}^{*} \\
\mathrm{CaO} \\
\mathrm{Mg0*}\end{array}$ & $\begin{array}{l}\mathrm{CaCO}_{3} \\
\mathrm{CaCO} \\
\mathrm{MgO}+\mathrm{MgSO}_{4}\end{array}$ \\
\hline Alkali & $\begin{array}{l}\mathrm{K}_{2} 0^{*} \\
\mathrm{Li}_{2} 0^{*} \\
\mathrm{Na}_{2} \mathrm{O}^{*}\end{array}$ & $\begin{array}{l}\mathrm{K}_{2} \mathrm{CO}_{3} \\
\mathrm{Li}_{2} \mathrm{CO}_{3} \\
\mathrm{Na}_{2} \mathrm{CO}_{3}\end{array}$ \\
\hline Waste $\operatorname{Mix}(a)$ & 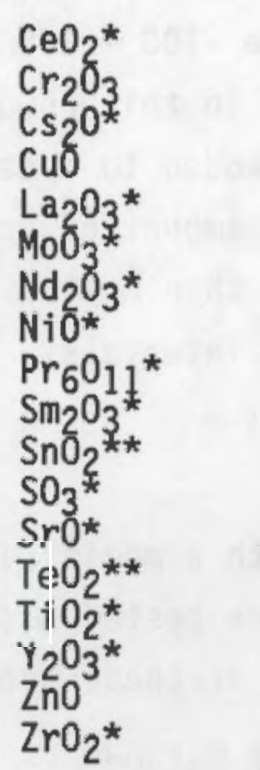 & $\begin{array}{l}\mathrm{CeO}_{2} \\
\mathrm{Cr}_{2} \mathrm{O}_{3} \\
\mathrm{Cs}_{2} \mathrm{CO}_{3} \\
\mathrm{CuO} \\
\mathrm{La}_{2} \mathrm{O}_{3} \\
\mathrm{MoO}_{3} \\
\mathrm{Nd}_{2} \mathrm{O}_{3} \\
\mathrm{NiO} \\
\mathrm{Pr}_{6} \mathrm{O}_{11} \\
\mathrm{Sm}_{2} \mathrm{O}_{3} \\
\mathrm{SnO}_{2} \\
\mathrm{MgSO}_{4} \\
\mathrm{SrCO}_{3} \\
\mathrm{TeO}_{2} \\
\mathrm{TiO}_{2} \\
\mathrm{Y}_{2} \mathrm{O}_{3} \\
\mathrm{ZnO} \\
\mathrm{ZrO}_{2}\end{array}$ \\
\hline
\end{tabular}

(a) Oxides listed here form the waste mix of the West Valley reference glasses WVCM-50 and WV-8801.

* $\quad$ Oxides form the waste mix of WVCM-47 reference glass.

** Additional oxides included in WV-8801 reference glass waste mix. 
Teflon(a) leach containers along with deaerated, deionized water (DIW). The sealed containers were placed in an air-tight enclosure which contained $250 \mathrm{~g}$ of fresh, unused Ascarite ${ }^{(b)}$ (a $\mathrm{CO}_{2}$ sorbent). This enclosure was then placed in a $90^{\circ} \mathrm{C}$ oven for the specified test period ( 7 or 28 days). The containers were briefly removed from the enclosure and gently agitated once a day.

The modifications of the standard MCC-3 leach test method used in these tests included use of deaerated, DIW instead of aerated DIW, and once-daily test container agitation instead of continuous agitation. The solubility of $\mathrm{CO}_{2}$ increases with $\mathrm{pH}$ and $\mathrm{CO}_{2}$ acts as a buffer in solution to prevent $\mathrm{pH}$ rise. As one does not expect a source of $\mathrm{CO}_{2}$ inside waste glass canisters, $\mathrm{CO}_{2}$ is not expected to act as a pH buffer. Deaerated DIW also does not contain $\mathrm{CO}_{2}$ and its use as a reactant prevents against pH buffering effects.

At the conclusion of the leach test period, an aliquot of the leachate was filtered through a $0.45-\mu m$ membrane. An aliquot of the filtered leachate was then filtered through an 18-A filter. The leached glass was removed from the leach containers and the containers were then rinsed with deionized water and filled with $40 \mathrm{~mL}$ of $1 \%$ nitric acid solution (acid strip) and placed in a $90^{\circ} \mathrm{C}$ oven overnight. The filtered aliquots $(0.45 \mu \mathrm{m}$ and $18 \mathrm{~A})$ and the acidstrip solutions were submitted for analysis. Analysis of the 18-A filtered solution, when compared to that of the $0.45-\mu \mathrm{m}$ filtered solution, provides information on dissolution product colloid formation. Analysis of the acidstrip solution is used to determine if dissolution products are plating out on the test container walls.

Normalized elemental mass releases were calculated using the following equation:

$$
N R_{i}=C_{i} /\left(F_{i} \times(S A \times W) / V\right)
$$

(a) Trademark of E. I. du Pont de Nemours \& Co., Inc.

(b) Trademark of Arthur H. Thomas. 
where $N R_{j}=$ normalized mass release of element $i\left(g / \mathrm{m}^{2}\right)$

$c_{i}=$ concentration of element $i$ in leachate $\left(\mathrm{g} / \mathrm{m}^{3}\right)$

$F_{i}=$ fraction of element $i$ in glass (dimensionless)

$S A=$ surface area of glass $/ g$ of glass $\left(m^{2} / g\right)^{(a)}$

$W=$ mass of glass sample leached $(g)$

$v=$ volume of leachant $\left(m^{3}\right)$.

\subsubsection{MCC-1 Leach Test Method}

Monolithic specimens of the glasses were cut on a low-speed diamondblade wafering saw with deionized water used for lubrication. These samples were placed in Teflon jars along with deaerated deionized water. The sealed jars were placed in an air-tight enclosure which contained $250 \mathrm{~g}$ of fresh, unused Ascarite. This enclosure was then placed in a $90^{\circ} \mathrm{C}$ oven for a period of 28 days.

At the conclusion of the leach test period, the $\mathrm{pH}$ of the leachate was determined from an aliquot of the leachate. The test specimens were removed from the test container and sufficient nitric acid was added to the leachate in the container such that a $1 \%$ nitric acid solution resulted. The container was then placed in a $90^{\circ} \mathrm{C}$ oven overnight. An aliquot of the solution was decanted and submitted for analysis.

Normalized elemental mass releases were calculated using the following equation:

$$
N R_{i}=C_{i} /\left[F_{i} \times(S A / V)\right]
$$

where $N R_{i}=$ normalized mass release of element $i\left(g / m^{2}\right)$

$c_{i}=$ concentration of element $i$ in leachate $\left(\mathrm{g} / \mathrm{m}^{3}\right)$

$F_{j}=$ fraction of element $i$ in glass (dimensionless)

$S A / V=$ surface area of glass/volume of leach solution $\left(m^{-1}\right)$. (b)

(a) Value of $0.02 \mathrm{~m}^{2} / \mathrm{g}$ used, SA $\mathrm{V}$ used $=2000 \mathrm{~m}^{-1}$.

(b) Value of $10 \mathrm{~m}^{-1}$ used. 


\subsection{GLASS AND SOLUTION ANALYSES}

All glass specimens were analyzed using inductively coupled plasma (ICP), laser fluorescence, and atomic absorption spectrophotometry techniques. Redox states were determined, when appropriate, with spectrophotometric techniques. Samples were prepared for optical examination by standard metallographic cutting and polishing techniques. Polished specimens were examined optically at various magnifications to obtain both a general view and details of any crystalline phases which might be present. The specimens were then prepared and submitted for scanning electron microscopy (SEM) analysis. Each specimen was first examined generally and with reference to the optical micrographs provided to the operator. Any non-glass phases seen were examined, usually at higher magnifications, and energy dispersive $x$-ray analysis (EDX) was used to provide an elemental analysis of these phases.

Solution analyses were performed with ICP, laser fluorescence, and atomic absorption (AA) techniques. All normalized releases obtained from MCC -3 methods were calculated from the elemental concentrations of the $0.45-\mu \mathrm{m}$ filtered solutions. Analyses of the 18-A and acid-strip solutions are not presented here. Analyses of the 18-A filtered solutions indicated that very few, if any, colloidal dissolution products were formed during the test periods. Analyses of the acid-strip solutions indicated that the dissolution products did not $\mathrm{plate}$ out on the test container walls.

\subsection{COMPOSITIDN REGIONS--FY 1987}

Two sets of glasses were tested at PNL during FY 1987 to investigate the effects of compositional variability. The first set, consisting of glasses designated DG-WVI through DG-WV8, was fabricated and tested from November 1986 to January 1987. The second set, consisting of glasses designated DG-WV15 through DG-WV30, was fabricated and tested from April to June 1987. The first set of eight glasses consisted of WVCM-47 and several, mainly onecomponent, variations of this composition. The second set of $16 \mathrm{glasses}$ consisted of the WVCM-50 reference glass and 15 vertices of a polyhedronal composition region centered around WVCM-50. The compositions of the WVCM-47 
TABLE 3.2. Composition of West Valley Reference Glasses WVCM-47 and WVCM-50

\begin{tabular}{|c|c|c|}
\hline \multirow[b]{2}{*}{$\underline{\text { Oxides }}$} & \multicolumn{2}{|c|}{ Weight Percent } \\
\hline & $\begin{array}{l}\text { DG-WV1; } \\
\text { WVCM-47 }\end{array}$ & $\begin{array}{l}\text { DG-WV30; } \\
\text { WVCM-50 }\end{array}$ \\
\hline $\begin{array}{l}\mathrm{Al}_{2} \mathrm{O}_{3} \\
\mathrm{~B}_{2} \mathrm{O}_{3} \\
\mathrm{BaO} \\
\mathrm{CaO} \\
\mathrm{CeO}_{2}\end{array}$ & $\begin{array}{r}8.05 \\
12.08 \\
0.05 \\
0.60 \\
0.07\end{array}$ & $\begin{array}{r}9.86 \\
12.27 \\
0.19 \\
0.82 \\
0.72\end{array}$ \\
\hline $\begin{array}{l}\mathrm{Cr}_{2} \mathrm{O}_{3} \\
\mathrm{Cs}_{2} \mathrm{O}^{\circ} \\
\mathrm{CuO} \\
\mathrm{Fe}_{2} \mathrm{O}_{3} \\
\mathrm{~K}_{2} \mathrm{O}\end{array}$ & $\begin{array}{r}0.20 \\
0.08 \\
0.00 \\
12.20 \\
1.29\end{array}$ & $\begin{array}{r}0.14 \\
0.07 \\
0.04 \\
11.93 \\
1.61\end{array}$ \\
\hline $\begin{array}{l}\mathrm{La}_{2} \mathrm{O}_{3} \\
\mathrm{Li}_{2} \mathrm{O} \\
\mathrm{MgO} \\
\mathrm{MnO}_{2} \\
\mathrm{MoO}_{3}\end{array}$ & $\begin{array}{l}0.03 \\
2.03 \\
1.33 \\
1.31 \\
0.01\end{array}$ & $\begin{array}{l}0.04 \\
2.22 \\
0.79 \\
1.21 \\
0.04\end{array}$ \\
\hline $\begin{array}{l}\mathrm{Na}_{2} \mathrm{O} \\
\mathrm{Nd}_{2} \mathrm{O} \\
\mathrm{NiO}_{2} \\
\mathrm{P}_{2} \mathrm{O}_{5} \\
\mathrm{PdO}_{2}\end{array}$ & $\begin{array}{l}9.27 \\
0.12 \\
0.28 \\
2.52 \\
0.00\end{array}$ & $\begin{array}{l}9.79 \\
0.14 \\
0.31 \\
2.47 \\
0.00\end{array}$ \\
\hline $\begin{array}{l}\mathrm{Pr}_{6} \mathrm{O}_{11} \\
\mathrm{RhO}_{2} \\
\mathrm{RuO}_{2} \\
\mathrm{SiO}_{2} \\
\mathrm{Sm}_{2} \mathrm{O}_{3}\end{array}$ & $\begin{array}{r}0.03 \\
0.00 \\
0.00 \\
42.59 \\
0.03\end{array}$ & $\begin{array}{r}0.04 \\
0.00 \\
0.00 \\
39.60 \\
0.02\end{array}$ \\
\hline $\begin{array}{l}\mathrm{SO}_{3} \\
\mathrm{SrO} \\
\mathrm{ThO}_{2} \\
\mathrm{TiO}_{2}\end{array}$ & $\begin{array}{l}0.30 \\
0.03 \\
3.61 \\
0.99\end{array}$ & $\begin{array}{l}0.23 \\
0.02 \\
3.52 \\
0.84\end{array}$ \\
\hline $\begin{array}{l}\mathrm{UO}_{2} \\
\mathrm{Y}_{2} \mathrm{O}_{3} \\
\mathrm{ZnO}_{2} \\
\mathrm{ZrO}_{2}\end{array}$ & $\begin{array}{l}0.56 \\
0.02 \\
0.00 \\
0.29\end{array}$ & $\begin{array}{l}0.61 \\
0.02 \\
0.03 \\
0.40\end{array}$ \\
\hline TOTAL & 99.97 & 99.99 \\
\hline
\end{tabular}


and WVCM-50 reference glasses are given in Table 3.2. Both glass compositions were developed by Catholic University of America (CUA).

\subsubsection{First Set of Glasses}

The first set of compositional variability glasses were based on variations about the WVCM-47 reference glass composition. The eight glasses fabricated and tested have the following descriptions:

\begin{tabular}{ll}
$\begin{array}{c}\text { Glass } \\
\text { Code }\end{array}$ & \multicolumn{1}{c}{ Description } \\
\cline { 2 - 2 } DG-WV1 & CUA reference glass - WVCM-47 \\
DG-WV2 & WVCM-47 glass with Ru, Rh, Pd oxides \\
DG-WV3 & Alternate glass (designated ATM-10) \\
DG-WV4 & WVCM-47 with higher $\mathrm{Na}_{2} 0(12.20$ vs. 9.27 wt\%) \\
DG-WV5 & WVCM-47 with lower $\mathrm{Al}_{2} \mathrm{O}_{3}(6.00$ vs. 8.05 wt\%) \\
DG-WV6 & WVCM-47 with higher $\mathrm{P}_{2} \mathrm{O}_{5}(3.50$ vs. 2.52 wt\%) \\
DG-WV7 & WVCM-47 with higher $\mathrm{ThO}_{2}(5.40$ vs. 3.61 wt\%) \\
DG-WV8 & WVCM-47 with lower $\mathrm{B}_{2} \mathrm{O}_{3}(7.30$ vs. 12.08 wt\%)
\end{tabular}

G1asses DG-WV2 and DG-WV4 through DG-WV8 are variations from DG-WV1 which were obtained by choosing higher or lower values of the oxides indicated, and proportionally adjusting the remaining components of DG-WVI to offset the change(s). The target and as-analyzed compositions of these glasses are given in Table 3.3. The as-analyzed compositions are each from a single analysis and are normalized to 100 weight percent (wt\%).

\subsubsection{Second Set of Glasses}

The second set of $16 \mathrm{glasses}$ tested in FY 1987 consisted of the WVCM-50 reference glass and 15 vertices of a polyhedronal composition variation region around WVCM-50. The compositional variation region is given in Table 3.4. The 15 vertex compositions were chosen using computer-aided experimental design techniques (Piepel 1988; Snee 1985) to provide optimum information for fitting linear mixture models (Cornell 1981). The target and as-analyzed compositions of the $16 \mathrm{glasses}$ are given in Table 3.5. 
TABLE 3.3. Compositions of First Set of FY 1987 Compositional Variability Glasses, wt\%

\begin{tabular}{|c|c|c|c|c|c|c|c|c|c|c|c|c|c|c|c|c|}
\hline \multirow[b]{2}{*}{ Oxide } & \multicolumn{2}{|c|}{$D G-L N 1$} & \multicolumn{2}{|c|}{$D G-W / 2$} & \multicolumn{2}{|c|}{$D G-W N 3$} & \multicolumn{2}{|c|}{ DG-WV4 } & \multicolumn{2}{|c|}{ DG-LN5 } & \multicolumn{2}{|c|}{ DG-LNS } & \multicolumn{2}{|c|}{$D G-W N 7$} & \multicolumn{2}{|c|}{ DG-LN8 } \\
\hline & Target & Anslyzed (a) & Terget & Analyzed & Target & Analyzed & Target & Analyzed & Target & Analyzed & Target & Analyzed & Target & Analyzed & Target & Analyzed \\
\hline $\mathrm{Al}_{2}$ & 8.05 & 8.74 & 8.04 & 8.61 & 6.50 & 7.16 & 7.79 & 8.38 & $6 . \infty$ & 6.90 & 7.97 & 8.55 & 7.90 & 8.84 & 8.49 & 9.01 \\
\hline & 12.08 & 12.15 & 12.07 & 12.17 & 9.25 & 9.33 & 11.69 & 11.77 & 12.35 & 12.41 & 11.96 & 12.15 & 11.86 & 12.15 & 7.30 & 7.51 \\
\hline Băo & 0.05 & 0.05 & 0.05 & 0.05 & 0.05 & 0.07 & 0.05 & 0.05 & 0.05 & 0.05 & 0.05 & 0.05 & 0.05 & 0.05 & 0.05 & 0.05 \\
\hline $\mathrm{CaO}$ & 0.60 & 0.68 & 0.60 & 0.83 & 0.56 & 0.63 & 0.58 & 0.68 & 0.61 & 0.68 & 0.59 & 0.69 & 0.59 & 0.65 & 0.63 & 0.67 \\
\hline $\mathrm{CeO}_{2}$ & 0.07 & 0.07 & 0.07 & 0.07 & 0.07 & 0.10 & 0.07 & 0.07 & 0.07 & 0.09 & 0.07 & 0.05 & 0.07 & 0.07 & 0.07 & 0.10 \\
\hline $\mathrm{Cr}_{2} \mathrm{O}_{3}$ & 0.20 & 0.19 & 0.20 & 0.20 & 0.29 & 0.29 & 0.19 & 0.20 & 0.20 & 0.21 & 0.20 & 0.19 & 0.20 & 0.20 & 0.21 & 0.19 \\
\hline $\mathrm{Cs}_{2} \mathrm{O}$ & 0.08 & 0.05 & 0.08 & 0.05 & 0.07 & 0.06 & 0.08 & 0.05 & 0.08 & 0.05 & 0.08 & 0.05 & 0.08 & 0.04 & 0.08 & 0.14 \\
\hline $\mathrm{Fe}_{2}^{2} \mathrm{O}_{3}$ & 12.20 & 11.74 & 12.19 & 11.72 & 11.30 & 10.81 & 11.81 & 11.06 & 12.41 & 11.91 & 12.08 & 11.55 & 11.98 & 11.55 & 12.87 & 12.29 \\
\hline & 1.29 & 1.16 & 1.29 & 0.91 & 3.33 & 1.92 & 1.25 & 1.71 & 1.32 & 1.50 & 1.28 & 0.70 & 1.27 & 1.27 & 1.36 & 1.71 \\
\hline Lă ${ }_{2} \mathrm{O}_{3}$ & 0.03 & 0.04 & 0.03 & 0.04 & 0.03 & 0.05 & 0.03 & 0.04 & 0.03 & 0.04 & 0.03 & 0.04 & 0.03 & 0.04 & 0.03 & 0.03 \\
\hline $\mathrm{Li}_{2}^{2} \mathrm{O}^{\circ}$ & 2.03 & 1.74 & 2.03 & 1.76 & 2.82 & 2.34 & 1.97 & 1.71 & 2.08 & 1.76 & 2.01 & 1.71 & 1.99 & 1.71 & 2.14 & 1.84 \\
\hline Mgס́ & 1.33 & 1.32 & 1.33 & 1.30 & 1.21 & 1.70 & 1.29 & 1.29 & 1.36 & 1.35 & 1.32 & 1.29 & 1.31 & 1.28 & 1.40 & 1.39 \\
\hline $\mathrm{MnO}_{2}$ & 1.31 & 1.30 & 1.31 & 1.32 & 1.22 & 1.76 & 1.27 & 1.30 & 1.34 & 1.36 & 1.30 & 1.30 & 1.29 & 1.29 & 1.38 & 1.37 \\
\hline $\mathrm{MoO}_{3}^{2}$ & 0.01 & 0.01 & 0.01 & 0.01 & $0 . \infty$ & $0 . \infty$ & 0.01 & 0.01 & 0.01 & 0.01 & 0.01 & 0. & 0.01 & 0. & 0.01 & 0.01 \\
\hline $\mathrm{Na}_{2} \mathrm{C}$ & 9.27 & 9.13 & 9.26 & 9.04 & 10.16 & 9.82 & 12.20 & 11.47 & 9.48 & 9.10 & 9.18 & 9.13 & 9.10 & 8.68 & 9.78 & 9.38 \\
\hline $\mathrm{Nd}_{2} \mathrm{O}_{3}$ & 0.12 & 0.12 & 0.12 & 0.11 & 0.17 & 0.16 & 0.12 & 0.14 & 0.12 & 0.12 & 0.12 & 0.11 & 0.12 & 0.09 & 0.13 & 0.13 \\
\hline $\mathrm{Ni \delta}$ & 0.28 & 0.31 & 0.28 & 0.27 & 0.32 & 0.36 & 0.27 & 0.27 & 0.29 & 0.30 & 0.28 & 0.28 & 0.28 & 0.28 & 0.30 & 0.30 \\
\hline $\mathrm{P}_{2} \mathrm{O}_{5}$ & 2.52 & 2.58 & 2.52 & 2.60 & 2.33 & 2.41 & 2.44 & 2.54 & 2.58 & 2.63 & 3.50 & 3.56 & 2.48 & 2.51 & 2.66 & 2.68 \\
\hline $\mathrm{PdO}_{2}$ & $0 . \infty$ & $0 . \infty$ & 0.01 & 0.01 & 0.01 & 0.01 & $0 . \infty$ & 0.00 & $0 . \infty$ & $0 . \infty$ & $0 . \infty$ & 0.00 & 0.00 & 0.00 & 0.00 & 0.00 \\
\hline $\operatorname{Pr}_{6} \mathrm{O}_{11}$ & 0.03 & 0.03 & 0.03 & 0.03 & 0.00 & 0.00 & 0.03 & 0.03 & 0.03 & 0.03 & 0.03 & 0.03 & 0.03 & 0.03 & 0.03 & 0.03 \\
\hline & $0 . \infty$ & $0 . \infty$ & 0.01 & 0.01 & 0.01 & 0.01 & $0 . \infty$ & 0.00 & $0 . \infty 0$ & 0.00 & $0 . \infty$ & $0 . \infty 0$ & 0.00 & $0 . \infty 0$ & 0.00 & 0.00 \\
\hline $\mathrm{RuO}_{2}^{2}$ & 0.00 & 0.00 & 0.08 & 0.08 & 0.07 & 0.07 & $0 . \infty$ & 0.00 & 0.00 & 0.00 & $0 . \infty$ & 0.00 & 0.00 & 0.00 & $0 . \infty$ & 0.00 \\
\hline sion, & 42.59 & 43.25 & 42.55 & 43.60 & 44.87 & 45.46 & 41.22 & 41.94 & 43.54 & 44.43 & 42.16 & 43.42 & 41.80 & 43.03 & 44.91 & 45.83 \\
\hline $\mathrm{Sm}_{2} \mathrm{O}$ & 0.03 & 0.03 & 0.03 & 0.03 & 0.00 & 0.00 & 0.03 & 0.03 & 0.03 & 0.03 & 0.03 & 0.03 & 0.03 & 0.03 & 0.03 & 0.03 \\
\hline $\mathrm{SO}_{3}^{-}$ & 0.30 & 0.30 & 0.30 & 0.30 & 0.27 & 0.27 & 0.29 & 0.20 & 0.31 & 0.31 & 0.30 & 0.30 & 0.29 & 0.29 & 0.32 & 0.32 \\
\hline Sro & 0.03 & 0.03 & 0.03 & 0.03 & 0.03 & 0.04 & 0.03 & 0.03 & 0.03 & 0.03 & 0.03 & 0.03 & 0.03 & 0.03 & 0.03 & 0.03 \\
\hline $\mathrm{ThO}_{2}$ & 3.61 & 2.86 & 3.61 & 2.80 & 3.34 & 2.73 & 3.50 & 2.94 & 3.69 & 3.11 & 3.58 & 2.75 & 5.40 & 3.83 & 3.81 & 2.75 \\
\hline $\mathrm{TiO}_{2}^{2}$ & 0.99 & 0.96 & 0.99 & 0.96 & 0.91 & 1.22 & 0.96 & 0.90 & 1.01 & 0.97 & 0.98 & 0.93 & 0.97 & 0.96 & 1.05 & 1.01 \\
\hline $\mathrm{wO}_{2}{ }^{2}$ & 0.58 & 0.54 & 0.56 & 0.53 & 0.52 & 0.54 & 0.54 & 0.54 & 0.57 & 0.00 & 0.56 & 0.53 & 0.55 & 0.46 & 0.59 & 0.58 \\
\hline $\mathrm{r}_{2} \mathrm{O}_{3}$ & 0.02 & 0.02 & 0.02 & 0.02 & 0.02 & 0.03 & 0.02 & 0.02 & 0.02 & 0.02 & 0.02 & 0.02 & 0.02 & 0.02 & 0.02 & 0.02 \\
\hline $2 \mathrm{rO}_{2}$ & 0.29 & 0.59 & 0.29 & 0.56 & 0.27 & 0.64 & 0.28 & 0.54 & 0.30 & 0.60 & 0.29 & 0.56 & 0.28 & 0.62 & 0.31 & 0.57 \\
\hline Total & 99.97 & 100 & 99.99 & 100 & 100 & 100 & 100.01 & 100 & 99.91 & 100 & 100.01 & 100 & 100.01 & 100 & 99.99 & 100 \\
\hline
\end{tabular}

(a) All glasses analyzed with ICP, AA, and laser fluorescence analysis techniques, compositions normalized to $100 \%$. 
TABLE 3.4. Definition of Compositional Variation Region Based on WVCM-50

Single Component Constraints, wt\%

\begin{tabular}{|c|c|c|}
\hline $9.0 \leq$ & $\mathrm{Al}_{2} \mathrm{O}_{3}$ & $\leq 12.0$ \\
\hline $10.0 \leq$ & $\mathrm{B}_{2} \mathrm{O}_{3}$ & $\leq 14.0$ \\
\hline $1.0 \mathrm{~s}$ & $\mathrm{BaO}+\mathrm{CaO}+\mathrm{MgO}(\mathrm{a})$ & $\leq 3.0$ \\
\hline $9.0 \leq$ & $\mathrm{Fe}_{2} \mathrm{O}_{3}$ & $\leq 15.0$ \\
\hline $11.6 \leq$ & $\mathrm{K}_{2} \mathrm{O}+\mathrm{Li}_{2} \mathrm{O}+\mathrm{Na}_{2} \mathrm{O}(\mathrm{a})$ & $\leq 15.6$ \\
\hline $0.5 \leq$ & $\mathrm{MnO}_{2}$ & $\leq 2.5$ \\
\hline $1.5 \leq$ & $\mathrm{P}_{2} \mathrm{O}_{5}$ & $\leq 3.5$ \\
\hline $36.0 \leq$ & $\mathrm{SiO}_{2}$ & $\leq 44.0$ \\
\hline $2.0 \leq$ & $\mathrm{ThO}_{2}$ & $\leq 5.25$ \\
\hline 0.15 & $\mathrm{UO}_{2}$ & $\leq 1.0$ \\
\hline $1.0 \leq$ & Others & $\leq 8.0$ \\
\hline
\end{tabular}

Multiple Component Constraints, wt\%

$\begin{aligned} 48 & \leq & \mathrm{SiO}_{2}+\mathrm{Al}_{2} \mathrm{O}_{3} & \leq 54 \\ 23.6 & \leq & \mathrm{Alkal} \text { is }+\mathrm{B}_{2} \mathrm{O}_{3} & \leq 27.6 \\ 3.3 & \leq & \left(\mathrm{SiO}_{2}+\mathrm{Al}_{2} \mathrm{O}_{3}\right) / \mathrm{Alkal} \text { is } & \leq 4.1 \\ 3.7 & \leq & \left(\mathrm{SiO}_{2}+\mathrm{Al}_{2} \mathrm{O}_{3}\right) / \mathrm{B}_{2} \mathrm{O}_{3} & \leq 4.7\end{aligned}$

(a) The $\mathrm{BaO}: \mathrm{CaO}: \mathrm{MgO}$ and $\mathrm{K}_{2} \mathrm{O}: \mathrm{Li}_{2} \mathrm{O}: \mathrm{Na}_{2} \mathrm{O}$ wt\% ratios were held constant at their levels in the WVCM-50 glass.

\subsection{COMPOSITION REGION--FY 1988}

The composition region studied during FY 1988 is described in Table 3.6. The region is based on composition variations of the West Valley reference glass composition WV-8801 (composition listed in Table 3.7). A computeraided experimental design approach was used to generate the 16-glass test matrix that was used to characterize the chemical durability of the composition region. The target and as-analyzed compositions of the 16 glasses are given in Tables 3.7a and b. Note that the glass labeled DG-WV33 has the WV-8801 composition. 
TABLE 3.5. Compositions of Second Set of FY 1987 Compositional Variability Glasses: DG-WV15 - DG-WV30, wt\%

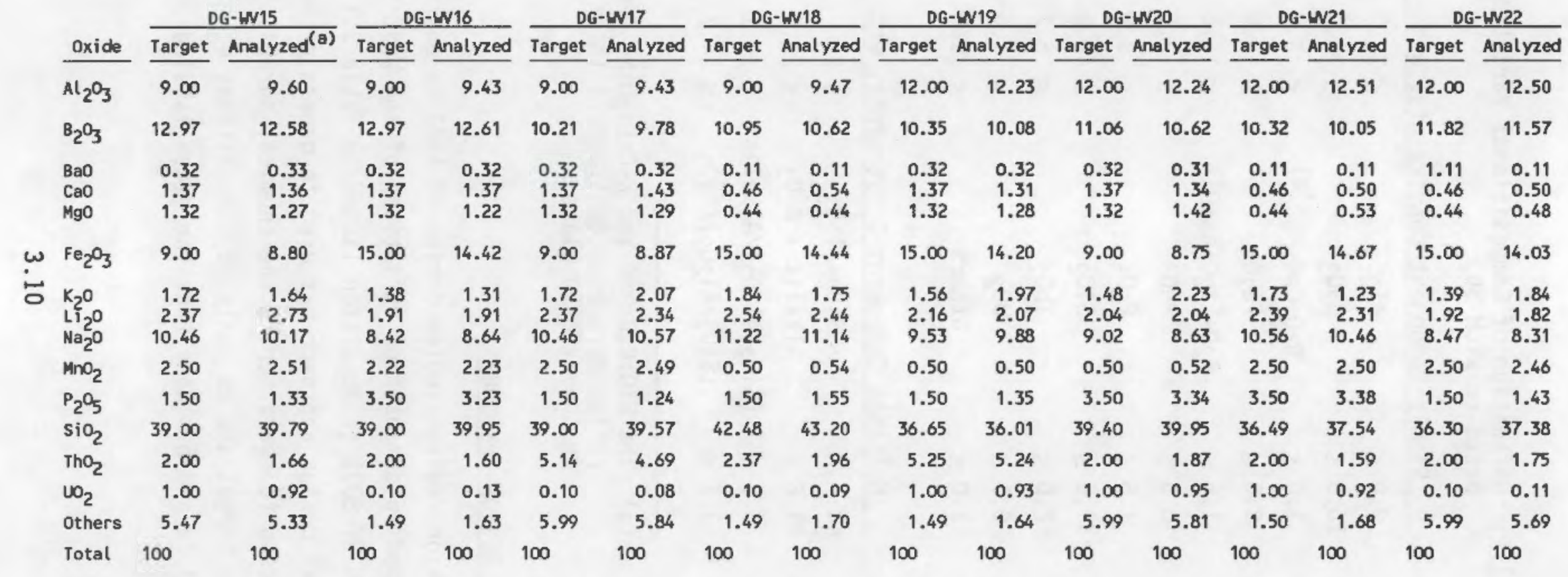


TABLE 3.5. (contd)

\begin{tabular}{|c|c|c|c|c|c|c|c|c|c|c|c|c|c|c|c|c|}
\hline \multirow[b]{2}{*}{ oxide } & \multicolumn{2}{|c|}{ DG-WNZ3 } & \multicolumn{2}{|c|}{ DG-W24 } & \multicolumn{2}{|c|}{ DG-WW25 } & \multicolumn{2}{|c|}{ DG-W26 } & \multicolumn{2}{|c|}{ DG-W27 } & \multicolumn{2}{|c|}{ DG-428 } & \multicolumn{2}{|c|}{ DG-W29 } & \multicolumn{2}{|c|}{$D G-19 \sqrt{30}$} \\
\hline & Target & Analyzed (a) & Target & Analyzed & $\overrightarrow{\text { Target }}$ & Analyzed & Target & Analyzed & Target & Analyzed & Target & Analyzed & Target & Analyzed & Target & Analyzed \\
\hline $\mathrm{Al}_{2} \mathrm{O}_{3}$ & 9.00 & 9.42 & 12.00 & 12.32 & 9.00 & 9.30 & $12 . \infty$ & 12.27 & 12.00 & 12.17 & 9.00 & 9.68 & 9.00 & 9.28 & 9.86 & 10.07 \\
\hline $\mathrm{B}_{2} \mathrm{O}_{3}$ & 12.97 & 12.48 & 14.00 & 13.22 & 11.28 & 10.90 & 14.00 & 13.38 & 13.01 & 12.58 & $11 . \infty$ & 10.66 & $12 . \infty$ & 11.45 & 12.27 & 11.88 \\
\hline $\begin{array}{l}\mathrm{BaO} \\
\mathrm{CaO} \\
\mathrm{MgO}\end{array}$ & $\begin{array}{l}0.11 \\
0.46 \\
0.44\end{array}$ & $\begin{array}{l}0.11 \\
0.50 \\
0.54\end{array}$ & $\begin{array}{l}0.11 \\
0.46 \\
0.44\end{array}$ & $\begin{array}{l}0.11 \\
0.48 \\
0.56\end{array}$ & $\begin{array}{l}0.11 \\
0.46 \\
0.44\end{array}$ & $\begin{array}{l}0.10 \\
0.50 \\
0.53\end{array}$ & $\begin{array}{l}0.32 \\
1.37 \\
1.32\end{array}$ & $\begin{array}{l}0.30 \\
1.34 \\
1.35\end{array}$ & $\begin{array}{l}0.11 \\
0.46 \\
0.44\end{array}$ & $\begin{array}{l}0.11 \\
0.49 \\
0.62\end{array}$ & $\begin{array}{l}0.11 \\
0.46 \\
0.44\end{array}$ & $\begin{array}{l}0.11 \\
0.48 \\
0.62\end{array}$ & $\begin{array}{l}0.32 \\
1.37 \\
1.32\end{array}$ & $\begin{array}{l}0.32 \\
1.33 \\
1.36\end{array}$ & $\begin{array}{l}0.19 \\
0.82 \\
0.79\end{array}$ & $\begin{array}{l}0.20 \\
0.84 \\
1.01\end{array}$ \\
\hline $\mathrm{Fe}_{2} \mathrm{O}_{3}$ & 14.57 & 14.24 & $9 . \infty 0$ & 8.67 & $9 . \infty$ & 8.67 & 9.00 & 8.67 & 9.00 & 8.68 & 12.72 & 12.11 & $9 . \infty$ & 8.74 & 11.93 & 11.48 \\
\hline $\begin{array}{l}\mathrm{K}_{2} \mathrm{O} \\
\mathrm{L}_{1}{ }_{2} \mathrm{O} \\
\mathrm{Na}_{2}{ }^{\mathrm{O}}\end{array}$ & $\begin{array}{l}1.38 \\
1.91 \\
8.42\end{array}$ & $\begin{array}{l}1.86 \\
1.80 \\
8.23\end{array}$ & $\begin{array}{l}1.60 \\
2.22 \\
9.78\end{array}$ & $\begin{array}{l}2.52 \\
2.05 \\
9.56\end{array}$ & $\begin{array}{l}1.53 \\
2.11 \\
9.30\end{array}$ & $\begin{array}{l}2.02 \\
2.03 \\
9.09\end{array}$ & $\begin{array}{l}1.51 \\
2.08 \\
9.18\end{array}$ & $\begin{array}{l}2.64 \\
2.00 \\
9.09\end{array}$ & $\begin{array}{r}1.72 \\
2.38 \\
10.49\end{array}$ & $\begin{array}{r}2.45 \\
2.28 \\
10.14\end{array}$ & $\begin{array}{l}1.49 \\
2.05 \\
9.06\end{array}$ & $\begin{array}{l}1.35 \\
2.05 \\
8.86\end{array}$ & $\begin{array}{r}1.84 \\
2.54 \\
11.22\end{array}$ & $\begin{array}{r}1.84 \\
2.57 \\
10.74\end{array}$ & $\begin{array}{l}1.61 \\
2.22 \\
9.70\end{array}$ & $\begin{array}{l}1.81 \\
2.10 \\
9.63\end{array}$ \\
\hline $\mathrm{MnO}_{2}$ & 0.50 & 0.51 & 2.50 & 2.44 & 2.45 & 2.40 & 0.50 & 0.55 & 0.50 & 0.51 & 0.50 & 0.52 & 0.50 & 0.50 & 1.21 & 1.20 \\
\hline $\mathrm{P}_{2} \mathrm{O}_{5}$ & 3.50 & 3.30 & 1.50 & 1.41 & 3.50 & 3.13 & 1.50 & 1.62 & 3.50 & 3.48 & 1.50 & 1.53 & 3.30 & 3.27 & 2.47 & 2.42 \\
\hline $\mathrm{SiO}_{2}$ & 39.00 & 39.31 & 42.00 & 42.10 & 44.00 & 45.00 & 40.38 & 40.95 & 36.14 & 36.72 & 42.68 & 43.38 & $44 . \infty 0$ & 44.68 & 39.60 & 40.06 \\
\hline $\mathrm{ThO}_{2}$ & 5.25 & 4.95 & 2.00 & 1.88 & 5.25 & 4.36 & 5.25 & 3.80 & 4.16 & 3.46 & 2.00 & 1.72 & 2.00 & 1.93 & 3.52 & 3.26 \\
\hline $\mathrm{uo}_{2}$ & 1.00 & 0.93 & 0.90 & 0.93 & 0.10 & 0.10 & 0.10 & 0.10 & 0.10 & 0.11 & 1.00 & 0.96 & 0.10 & 0.10 & 0.61 & 0.59 \\
\hline others & 1.49 & 1.83 & 1.49 & 1.74 & 1.47 & 1.88 & 1.49 & 1.95 & 5.99 & 6.19 & 5.99 & 5.94 & 1.49 & 1.88 & 3.11 & 3.46 \\
\hline Total & 100 & 100 & 100 & 100 & 100 & 100 & 100 & 100 & 100 & 100 & 100 & 100 & 100 & 100 & 100 & 100 \\
\hline
\end{tabular}

(a) All glasses analyzed with ICP, $M$, and laser fluorescence techniques, compositions normal ized to 100\%.

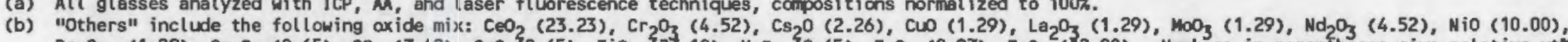

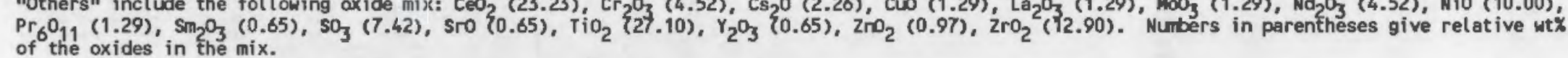


TABLE 3.6. Definition of Compositional Variation Region Based on WV-8801, wt\%

\begin{tabular}{l}
\multicolumn{1}{c}{ Component } \\
\hline $\mathrm{Al}_{2} \mathrm{O}_{3}$ \\
$\mathrm{~B}_{2} \mathrm{O}_{3}$ \\
$\mathrm{BaO}+\mathrm{CaO}+\mathrm{MgO}^{(\mathrm{a})}$ \\
$\mathrm{Fe}_{2} \mathrm{O}_{3}$ \\
$\mathrm{~K}_{2} \mathrm{O}+\mathrm{Li}_{2} \mathrm{O}+\mathrm{Na}_{2} \mathrm{O}(\mathrm{a})$ \\
$\mathrm{MnO}_{2}$ \\
$\mathrm{P}_{2} \mathrm{O}_{5}$ \\
$\mathrm{SiO}_{2}$ \\
$\mathrm{ThO}_{2}$ \\
$\mathrm{UO}_{2}$ \\
$\mathrm{Others}(\mathrm{b})$ \\
\\
$\mathrm{SiO}_{2}+\mathrm{Al}_{2} \mathrm{O}_{3}$ \\
$\mathrm{Alkalis} \mathrm{B}_{2} \mathrm{O}_{3}$ \\
$\left(\mathrm{SiO}_{2}+\mathrm{Al}_{2} \mathrm{O}_{3}\right) / \mathrm{Al}$ kal is \\
$\left(\mathrm{SiO}_{2}+\mathrm{Al}_{2} \mathrm{O}_{3}\right) / \mathrm{B}_{2} \mathrm{O}_{3}$ \\
$\mathrm{SiO}_{2} / \mathrm{Al}_{2} \mathrm{O}_{3}$
\end{tabular}

\begin{tabular}{c} 
WV-8801 \\
\hline 7.75 \\
9.26 \\
1.77 \\
12.04 \\
16.32 \\
1.30 \\
2.48 \\
42.50 \\
3.55 \\
0.54 \\
2.49 (c)
\end{tabular}

Single Component Constraints
Lower Bound $\quad$ Upper Bound

$$
4.5^{(d)}
$$

10.0

$6.0^{(e)}$

13.0

0.5

2.5

10.0

16.0

12.0

$21.0^{(f)}$

0.1

2.0

0.5

4.0

38.0

45.0

2.0

5.0

0.1

2.0

1.0

8.0

Multiple Component Constraints
Lower Bound $\quad$ Upper Bound

50.25

45.0

52.0

25.58

23.0

29.0

3.08

2.6

4.3

5.43

4.0

6.5

5.48

3.8

8.0

(a) The $\mathrm{BaO}: \mathrm{CaO}: \mathrm{MgO}$ and $\mathrm{K}_{2} \mathrm{O}: \mathrm{LiO}_{2}: \mathrm{Na}_{2} \mathrm{O}$ ratios are held constant at their levels in the WV-8801 glass.

(b) Others include the following oxide mix: $\mathrm{CeO}_{2}$ (6.35), $\mathrm{Cr}_{2} \mathrm{O}_{3}$ (5.56), $\mathrm{Cs}_{2} \mathrm{O}(3.57)$, $\mathrm{CuO}(2.38), \mathrm{La}_{2} \mathrm{O}_{3}(1.59), \mathrm{MoO}_{3}(1.98)$, $\mathrm{Nd}_{2} \mathrm{O}_{3}(5.56)$, NiO (9.92), $\mathrm{PdO}_{2}(1.19), \mathrm{Pr}_{6} \mathrm{O}_{11}(1.59), \mathrm{RhO}_{2}$ $(0.79), \mathrm{RuO}_{2}(3.17), \mathrm{Sm}_{2} \mathrm{O}_{3}(0.79), \mathrm{SnO}_{2}(1.19), \mathrm{SO}_{3}(8.73)$, SrO (0.79), $\mathrm{TeO}_{2}(0.40)$, $\mathrm{TiO} 2(35.32), \mathrm{Y}_{2} \mathrm{O}_{3}(0.79)$, $\mathrm{ZuO}_{2}$ $(0.79), \mathrm{ZrO}_{2}(7.54)$. Number in parentheses give relative wt\% of the oxides in this mix.

(c) This level for "Others" was obtained by subtracting from 100 the total weight percent levels of the preceding ten components.

(d) Due to the multiple component constraints, the attainable lower 1 imit for $\mathrm{Al}_{2} \mathrm{O}_{3}$ is $5.0 \mathrm{wt} \%$.

(e) Due to the multiple component constraints, the attainable lower 1 imit for $\mathrm{B}_{2} \mathrm{O}_{3}$ is $6.92 \mathrm{wt \%}$.

(f) Due to the multiple component constraints, the attainable upper 1 imit for alkal is is 20.0 wt\%. 
TABLE 3.7. Target and "As Analyzed" Compositions (by weight perrent) for the 16 WV-8801 Compositional Variation Glasses(a)

\begin{tabular}{|c|c|c|c|c|c|c|c|c|c|c|c|}
\hline Gt & $\mathrm{Al}_{2} \mathrm{O}_{3}$ & $\mathrm{~B}_{2} \mathrm{O}_{3}$ & $\begin{array}{r}\mathrm{BaO} \\
+\mathrm{C}+\mathrm{aO} \\
+\mathrm{MgO} \\
\end{array}$ & $\mathrm{Fe}_{2} \mathrm{O}_{3}$ & $\begin{array}{r}\mathrm{K}_{2} \\
+\mathrm{L}_{2} \\
+\mathrm{N}_{2} \\
+\mathrm{Na}_{2} \\
\end{array}$ & $\mathrm{MnO}_{2}$ & $\mathrm{P}_{2} \mathrm{O}_{5}$ & $\mathrm{SiO}_{2}$ & $\mathrm{O}_{2}$ & $\mathrm{UO}_{2}$ & Oth \\
\hline -WW33 & 75 & 9.26 & 1.77 & 12.04 & 16.32 & 30 & 2.48 & 2.50 & .55 & 0.54 & \\
\hline$-1+\sqrt{34}$ & .00 & .25 & 0.50 & 10.00 & 17.31 & .00 & 4 & 00 & .00 & .00 & \\
\hline - WV35 & 10.00 & & 2.50 & .00 & 3.46 & .00 & 50 & 30 & 15 & .00 & \\
\hline$-w 136$ & & .56 & 0.50 & 6.00 & 2.00 & .10 & 0.50 & 0 & 10 & 0.10 & \\
\hline -WN37 & 10.0 & & 0.50 & 0.00 & 18.80 & .10 & 0.50 & 10 & 00 & 0.10 & 00 \\
\hline -wV38 & 10.0 & & 0.50 & 0.00 & 15.17 & 00 & 0.50 & 1.90 & .00 & 0.10 & 00 \\
\hline -WV39 & 10.00 & .00 & 2.50 & 10.00 & 17.00 & .10 & 4.00 & 3.00 & .00 & .1 & 30 \\
\hline$-W N 40$ & 5 & & 2.50 & 16.00 & 15.32 & 10 & 0.50 & .36 & .00 & $2 . C$ & bo \\
\hline$-W 44$ & 5. & & 0.50 & 0.00 & 19.47 & .10 & 4.00 & 5.00 & .52 & 2.0 & 1.00 \\
\hline -WW42 & 5.0 & & 2.50 & 0.00 & 16.48 & .00 & 4.00 & 0.00 & .00 & 0.10 & 00 \\
\hline$-W 43$ & 10.00 & .00 & 0.50 & 10.00 & 12.09 & .00 & 2.41 & 2.00 & .00 & 2.00 & . \\
\hline$-6 w 4$ & & 1 & .5 & .00 & .52 & .10 & 0.50 & .00 & .00 & 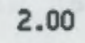 & 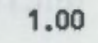 \\
\hline 5 & 10.0 & & 0.5 & 0 & 46 & & 4. & 0 & 10 & 0.10 & 1. \\
\hline & & & 2.5 & 0 & 6.00 & 2.8 & 0 & 00 & 00 & 0 & 1 \\
\hline & & & 0.5 & & 00 & & & 20 & & 0 & 1 \\
\hline 5-W48 & 10.00 & 11.40 & 2.50 & .00 & 2.00 & 0.10 & 4.00 & 38.00 & 2.00 & 2.00 & 0 \\
\hline
\end{tabular}

As-Analyzed (b)

\begin{tabular}{|c|c|c|c|c|c|c|c|c|c|c|c|}
\hline Glass & $\mathrm{Al}_{2} \mathrm{O}_{3}$ & $\mathrm{~B}_{2} \mathrm{O}_{3}$ & $\begin{array}{r}8 \mathrm{aO} \\
+\mathrm{CaO} \\
+\mathrm{HgO} \\
\end{array}$ & $\mathrm{Fe}_{2} \mathrm{O}_{3}$ & $\begin{array}{r}\mathrm{K}_{2} \mathrm{O} \\
+\mathrm{t} \mathrm{L}_{2} \\
+\mathrm{Na}_{2} \mathrm{O} \\
\end{array}$ & $\mathrm{MnO}_{2}$ & $\mathrm{P}_{2} \mathrm{O}_{5}$ & $\mathrm{SiO}_{2}$ & $\mathrm{ThO}_{2}$ & $\mathrm{NO}_{2}$ & Others \\
\hline DG-WW33 & 8.22 & 9.03 & 1.43 & 11.45 & 16.86 & 1.28 & 2.47 & 42.50 & 3.37 & 0.50 & 2.89 \\
\hline$D G-W 34$ & 5.17 & 10.81 & 0.66 & 9.77 & 17.76 & 1.98 & 1.87 & 40.00 & 1.92 & 1.83 & 8.23 \\
\hline DG-W/35 & 10.02 & 7.15 & 2.54 & 14.98 & 18.19 & 1.95 & 0.60 & 38.00 & 2.78 & 2.40 & 1.39 \\
\hline$D G-W \sqrt{36}$ & 5.69 & 10.80 & 0.58 & 14.66 & 12.43 & 0.12 & 0.59 & 41.10 & 5.81 & 0.13 & 8.09 \\
\hline$D G-W \sqrt{37}$ & 9.98 & 7.78 & 0.52 & 9.77 & 19.11 & 0.13 & 0.50 & 42.00 & 2.09 & 0.14 & 7.99 \\
\hline DG-WN38 & 10.24 & 7.58 & 0.57 & 9.67 & 15.96 & 1.97 & 0.60 & 40.90 & 4.13 & 0.09 & 8.29 \\
\hline DG-W39 & 10.05 & 11.22 & 2.40 & 9.28 & 17.72 & 0.11 & 3.81 & 38.00 & 5.11 & 0.10 & 2.20 \\
\hline DG-WN40 & 6.09 & 7.53 & 2.60 & 15.35 & 15.54 & 0.12 & 0.60 & 44.36 & 4.19 & 1.82 & 1.80 \\
\hline OG-WN41 & 5.92 & 7.26 & 0.74 & 9.48 & 18.36 & 0.12 & 3.80 & 45.00 & 5.27 & 1.99 & 2.06 \\
\hline DG-WN42 & 5.55 & 6.75 & 2.44 & 9.53 & 17.01 & 1.95 & 3.68 & 40.00 & 5.00 & 0.12 & 7.97 \\
\hline DG-WN43 & 10.04 & 12.43 & 0.72 & 9.53 & 13.11 & 1.94 & 2.39 & 42.00 & 4.14 & 1.92 & 1.78 \\
\hline DG-WN44 & 8.32 & 11.50 & 0.70 & 15.81 & 17.32 & 0.13 & 0.62 & 38.00 & 3.71 & 2.15 & 1.74 \\
\hline DG-W45 & 10.21 & 7.31 & 0.59 & 15.51 & 18.82 & 2.01 & 3.90 & 38.00 & 1.79 & 0.10 & 1.76 \\
\hline$D G-W N 46$ & 7.00 & 12.23 & 2.44 & 10.39 & 16.53 & 1.96 & 0.59 & 45.00 & 2.16 & 0.11 & 1.59 \\
\hline DG-WN47 & 5.69 & 11.21 & 0.58 & 14.94 & 13.09 & 1.94 & 3.93 & 45.00 & 1.95 & 0.12 & 1.55 \\
\hline DG-W48 & 9.43 & 10.56 & 2.45 & 9.24 & 13.12 & 0.12 & 4.28 & 38.00 & 2.06 & 1.90 & 8.84 \\
\hline
\end{tabular}

(a) DGW-33 is the $W \mathrm{~N}-8801$ reference glass, while glasses DG-WN34 to DG-WN48 are extreme vertices of the compositional region defined in Table 1.

(b) The $\mathrm{SiO}_{2}$ values of the "as analyzed" glass compositions were set to the target values due to a relatively large bias in the ICP analyses of $\mathrm{SiO}_{2}$. 


\subsection{GLASS REDOX ADJUSTMENT}

Four redox-adjusted glasses, DG-WV11R through DG-WV14R, were fabricated for this study. The target composition of the glass varies slightly from the WVCM-50 composition, with approximately 1 wt\% less $\mathrm{B}_{2} \mathrm{O}_{3}$ and 1 wt\% more $\mathrm{K}_{2} \mathrm{O}$. The redox state of the $\mathrm{glass}$, as measured by the $\mathrm{Fe}^{2+} / \mathrm{Fe}^{3+}$ ratio, was varied over a range of 0.07 to 0.42 . This range represents the estimated $\mathrm{Fe}^{2+} / \mathrm{Fe}^{3+}$ variability of glass to be produced by West valley. The target oxide and as-analyzed compositions of these glasses are given in Table $3.8 ; \mathrm{Fe}^{2+} / \mathrm{Fe}^{3+}$ ratios are given in Table 3.9 .

\subsection{GLASS HEAT TREATMENTS}

Nuclear waste glasses can devitrify at temperatures below the melter processing temperature. Devitrification is the formation of crystals in the glass. Crystal formation may lead to inhomogeneity of the glass product and, in some cases, a decrease in chemical durability as was observed when an excessive amount of acmite crystals formed in SRL-165 glass (Jantzen, Bickford, and Karraker 1984). To determine the type and extent of devitrification, the glass may be subjected to temperature conditions representing expected thermal history, e.g., slow cooling conditions simulating the cooling of a glass-filled canister. Devitrification kinetics may also be examined with a method involving heat treating specimens under isothermal conditions so that any thermally activated transformations that occur in the material can be identified and characterized.

To study the effects of thermal history on devitrification and chemical durability, the target composition used in the redox experiments was heat treated, then subjected to leach testing in FY 1987. The determination of these effects provides information regarding the processing conditions, e.g., canister cooling rates and melter idling conditions, necessary for producing a durable product. The data collected support glass qualification efforts. The glass was submitted to two types of heat treatment--slow cooling and isothermal. The slow cooling treatment simulates the thermal history of cooling glass in a recently filled waste canister intended for repository 
TABLE 3.8. Compositions of Redox Adjusted Glasses (in wt\%)

\begin{tabular}{|c|c|c|c|c|c|}
\hline \multirow[b]{2}{*}{ Oxide } & \multirow[b]{2}{*}{ Target } & \multicolumn{3}{|c|}{ As-Analyzed (a) } & \multirow[b]{2}{*}{ DG-WV14R } \\
\hline & & $\underline{\mathrm{OG}-W V 11 R}$ & DG-WV12R & DG-WV13R & \\
\hline $\begin{array}{l}\mathrm{Al}_{2} \mathrm{O}_{3} \\
\mathrm{~B}_{2} \mathrm{O}_{3} \\
\mathrm{BaO} \\
\mathrm{CaO} \\
\mathrm{CeO}_{2}\end{array}$ & $\begin{array}{r}9.99 \\
10.69 \\
0.05 \\
0.60 \\
0.07\end{array}$ & $\begin{array}{l}10.46 \\
10.97 \\
0.05 \\
0.62 \\
0.07\end{array}$ & $\begin{array}{r}10.52 \\
10.82 \\
0.05 \\
0.63 \\
0.07\end{array}$ & $\begin{array}{r}10.58 \\
10.78 \\
0.05 \\
0.61 \\
0.07\end{array}$ & $\begin{array}{r}10.58 \\
10.98 \\
0.05 \\
0.61 \\
0.07\end{array}$ \\
\hline $\begin{array}{l}\mathrm{Cr}_{2} \mathrm{O}_{3} \\
\mathrm{Cs}_{2} \mathrm{O} \\
\mathrm{Fe}_{2} \mathrm{O}_{3} \\
\mathrm{~K}_{2} \mathrm{O} \\
\mathrm{La}_{2} \mathrm{O}_{3}\end{array}$ & $\begin{array}{r}0.18 \\
0.08 \\
12.19 \\
2.44 \\
0.03\end{array}$ & $\begin{array}{r}0.17 \\
0.09 \\
11.90 \\
2.67 \\
0.03\end{array}$ & $\begin{array}{r}0.17 \\
0.10 \\
11.82 \\
2.85 \\
0.03\end{array}$ & $\begin{array}{r}0.17 \\
0.12 \\
11.90 \\
2.87 \\
0.03\end{array}$ & $\begin{array}{r}0.17 \\
0.13 \\
11.99 \\
2.19 \\
0.03\end{array}$ \\
\hline $\begin{array}{l}\mathrm{Li}_{2} \mathrm{O} \\
\mathrm{MgO} \mathrm{O} \\
\mathrm{MnO}_{2} \\
\mathrm{MoO}_{3} \\
\mathrm{Na}_{2} \mathrm{O}\end{array}$ & $\begin{array}{l}2.63 \\
1.33 \\
1.31 \\
0.01 \\
9.58\end{array}$ & $\begin{array}{l}2.63 \\
1.25 \\
1.32 \\
0.01 \\
9.52\end{array}$ & $\begin{array}{l}2.57 \\
1.25 \\
1.31 \\
0.01 \\
9.58\end{array}$ & $\begin{array}{l}2.59 \\
1.26 \\
1.31 \\
0.01 \\
9.38\end{array}$ & $\begin{array}{l}2.61 \\
1.25 \\
1.31 \\
0.01 \\
9.51\end{array}$ \\
\hline $\begin{array}{l}\mathrm{Nd}_{2} \mathrm{O}_{3} \\
\mathrm{NiO} \\
\mathrm{P}_{2} \mathrm{D}_{5} \\
\mathrm{PdO}_{2} \\
\mathrm{Pr}_{6} \mathrm{O}_{11}\end{array}$ & $\begin{array}{l}0.12 \\
0.28 \\
2.52 \\
0.01 \\
0.03\end{array}$ & $\begin{array}{l}0.07 \\
0.31 \\
2.48 \\
0.01 \\
0.03\end{array}$ & $\begin{array}{l}0.08 \\
0.29 \\
2.52 \\
0.01 \\
0.03\end{array}$ & $\begin{array}{l}0.09 \\
0.31 \\
2.50 \\
0.01 \\
0.03\end{array}$ & $\begin{array}{l}0.08 \\
0.29 \\
2.50 \\
0.01 \\
0.03\end{array}$ \\
\hline $\begin{array}{l}\mathrm{RhO}_{2} \\
\mathrm{RuO}_{2} \\
\mathrm{SiO}_{2} \\
\mathrm{Sm}_{2} \mathrm{O}_{3} \\
\mathrm{SO}_{3}\end{array}$ & $\begin{array}{r}0.01 \\
0.08 \\
39.96 \\
0.03 \\
0.30\end{array}$ & $\begin{array}{r}0.01 \\
0.08 \\
40.61 \\
0.03 \\
0.31\end{array}$ & $\begin{array}{r}0.01 \\
0.08 \\
40.16 \\
0.03 \\
0.30\end{array}$ & $\begin{array}{r}0.01 \\
0.08 \\
40.18 \\
0.03 \\
0.31\end{array}$ & $\begin{array}{r}0.01 \\
0.08 \\
40.20 \\
0.03 \\
0.30\end{array}$ \\
\hline $\begin{array}{l}\mathrm{SrO} \\
\mathrm{ThO}_{2} \\
\mathrm{TiO}_{2} \\
\mathrm{UO}_{2} \\
\mathrm{Y}_{2} \mathrm{O}_{3} \\
\mathrm{ZrO}_{2}\end{array}$ & $\begin{array}{l}0.03 \\
3.61 \\
0.99 \\
0.56 \\
0.02 \\
0.29\end{array}$ & $\begin{array}{l}0.03 \\
2.20 \\
0.95 \\
0.63 \\
0.02 \\
0.46\end{array}$ & $\begin{array}{l}0.03 \\
2.53 \\
0.94 \\
0.65 \\
0.01 \\
0.54\end{array}$ & $\begin{array}{l}0.03 \\
2.48 \\
0.96 \\
0.69 \\
0.02 \\
0.52\end{array}$ & $\begin{array}{l}0.03 \\
2.59 \\
0.96 \\
0.64 \\
0.02 \\
0.73\end{array}$ \\
\hline TOTAL & 100.02 & 100.00 & 100.00 & 100.00 & 100.00 \\
\hline $\mathrm{Fe}^{2}$ & & 0.068 & 0.126 & 0.236 & 0.424 \\
\hline
\end{tabular}

(a) ICP, AA, and laser fluorescence analyses, normalized to $100 \%$.

(b) Analyzed with spectrophotometric technique. 


\begin{tabular}{|c|c|c|c|c|}
\hline & $\underline{D G-W V 11 R}$ & $\underline{D G-W V 12 R}$ & DG-WV13R & DG-WV14R \\
\hline & 0.068 & 0.131 & 0.237 & 0.409 \\
\hline & 0.068 & 0.124 & 0.237 & 0.427 \\
\hline & 0.068 & 0.123 & 0.233 & 0.429 \\
\hline & 0.069 & 0.126 & 0.238 & 0.429 \\
\hline Average & 0.068 & 0.126 & 0.236 & 0.424 \\
\hline $\begin{array}{l}\text { Standard } \\
\text { Deviation }\end{array}$ & $5.00 \mathrm{E}-04$ & $3.56 \mathrm{E}-03$ & $2.22 \mathrm{E}-03$ & $9.71 \mathrm{E}-03$ \\
\hline
\end{tabular}

disposal. The isothermal treatments are constant-temperature heat treatments, conducted at different temperatures for varying lengths of time.

\subsubsection{Simulated Canister Cooling}

Glasses were heat treated using programmed furnaces. The furnace controller was "programmed" with a series of 1 inear cooling/heating rates which closely approximate cooling curves. Plots representing the actual cooling history of the glass samples are given in Figures 3.1 through 3.6. The furnace was programmed to shut off and cool down once a temperature of $400^{\circ} \mathrm{C}$ was reached. It took approximately $5 \mathrm{~h}$ for the furnace to reach room temperature $\left(25^{\circ} \mathrm{C}\right)$ from this temperature. The glass structure is essentially frozen at $400^{\circ} \mathrm{C}$ and the subsequent $5-\mathrm{h}$ cooling to $25^{\circ} \mathrm{C}$ does not affect the microstructure of the glass.

The cooling curves used were simulated versions of actual glass cooling curves obtained from two instrumented full-size glass canisters produced by West Valley (designated TC-18 and TC-23). The thermocouple positions in the canisters are illustrated in Figures 3.7 and 3.8. Samples HT-S-1 and 2 were cooled with cooling curves simulating temperatures observed with thermocouples placed approximately 30 in. from the bottom of canister TC-18. These thermocouples happened to be placed near pour batch boundaries; the glass was poured into the canister in batches, not continuously. This is why the glass is seen to cool, then suddenly heat up, then cool again. The cooling scheme used to treat HT-S-1 is the slowest cooling of the six schemes used. 


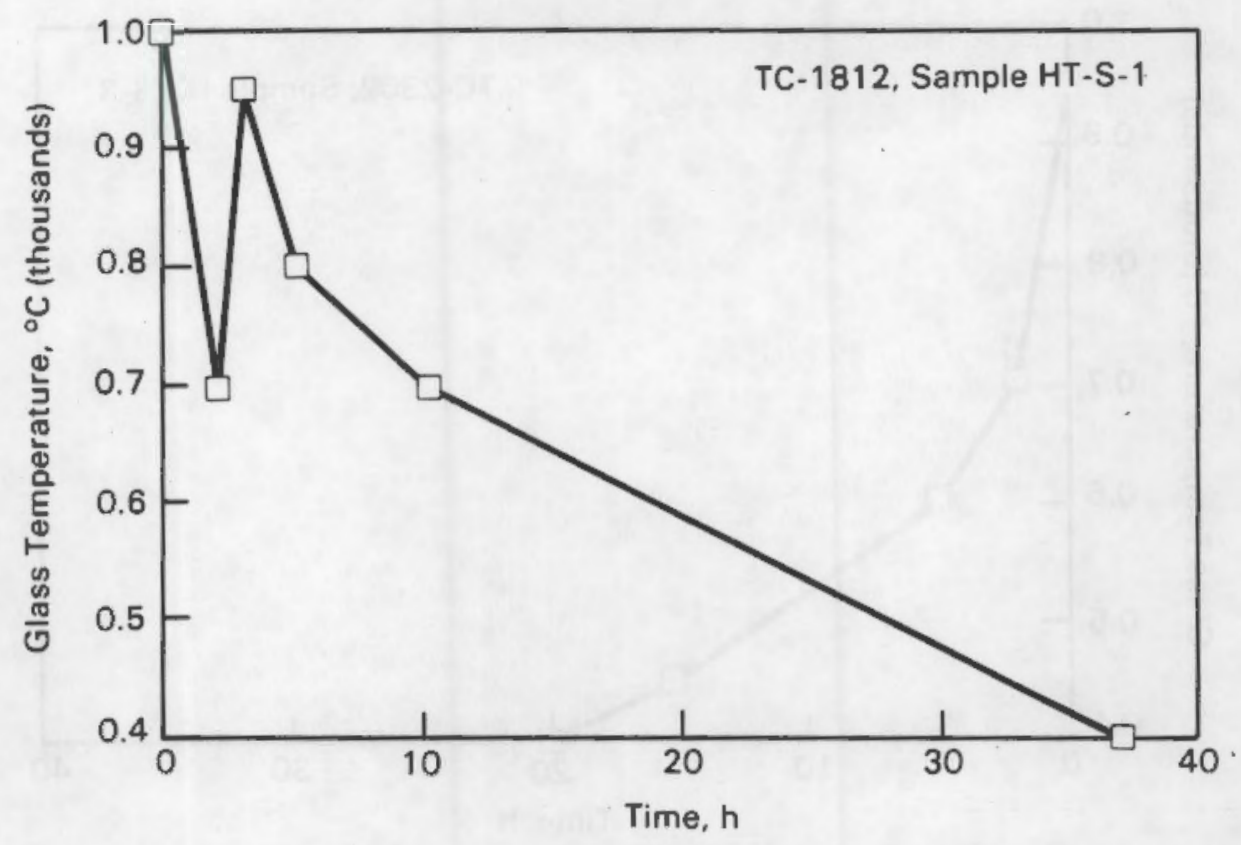

FIGURE 3.1. Sample HT-S-1 Cooling History

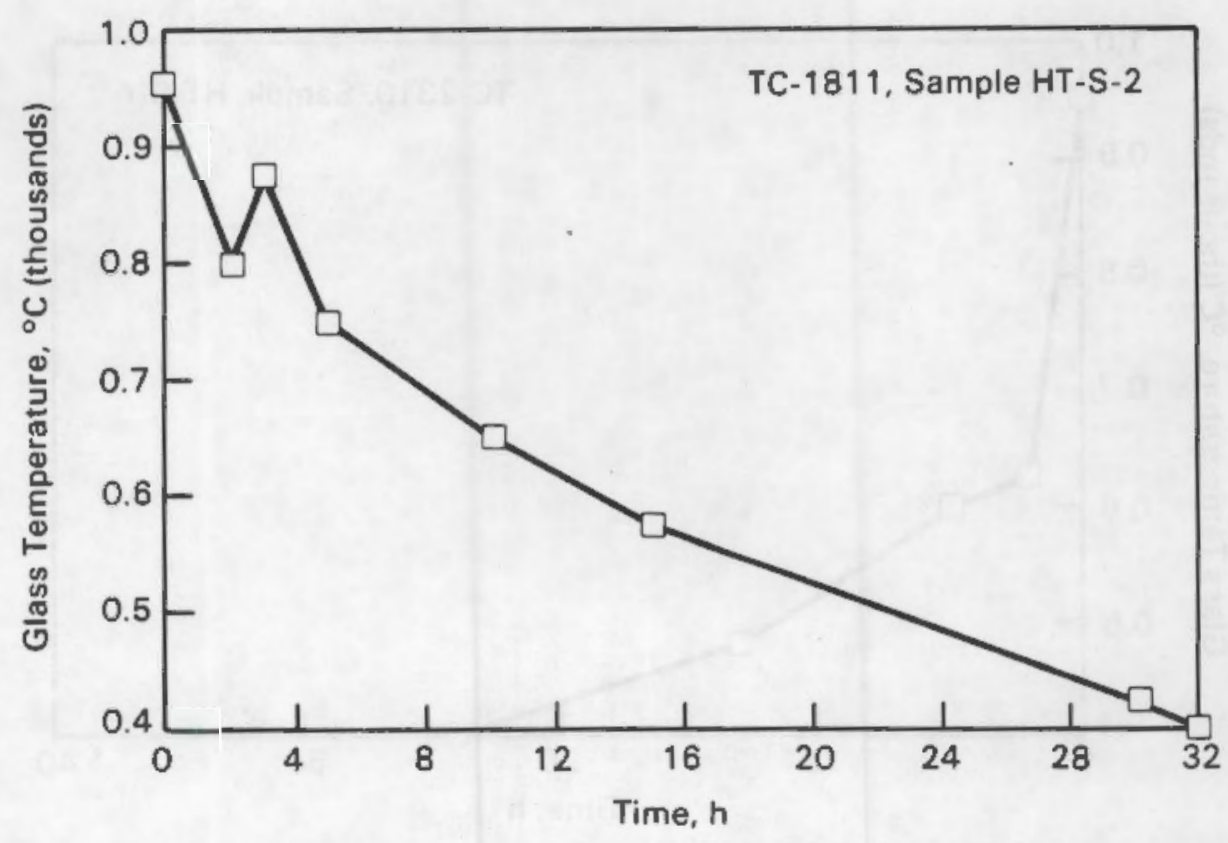

FIGURE 3.2. Sample HT-S-2 Cooling History 


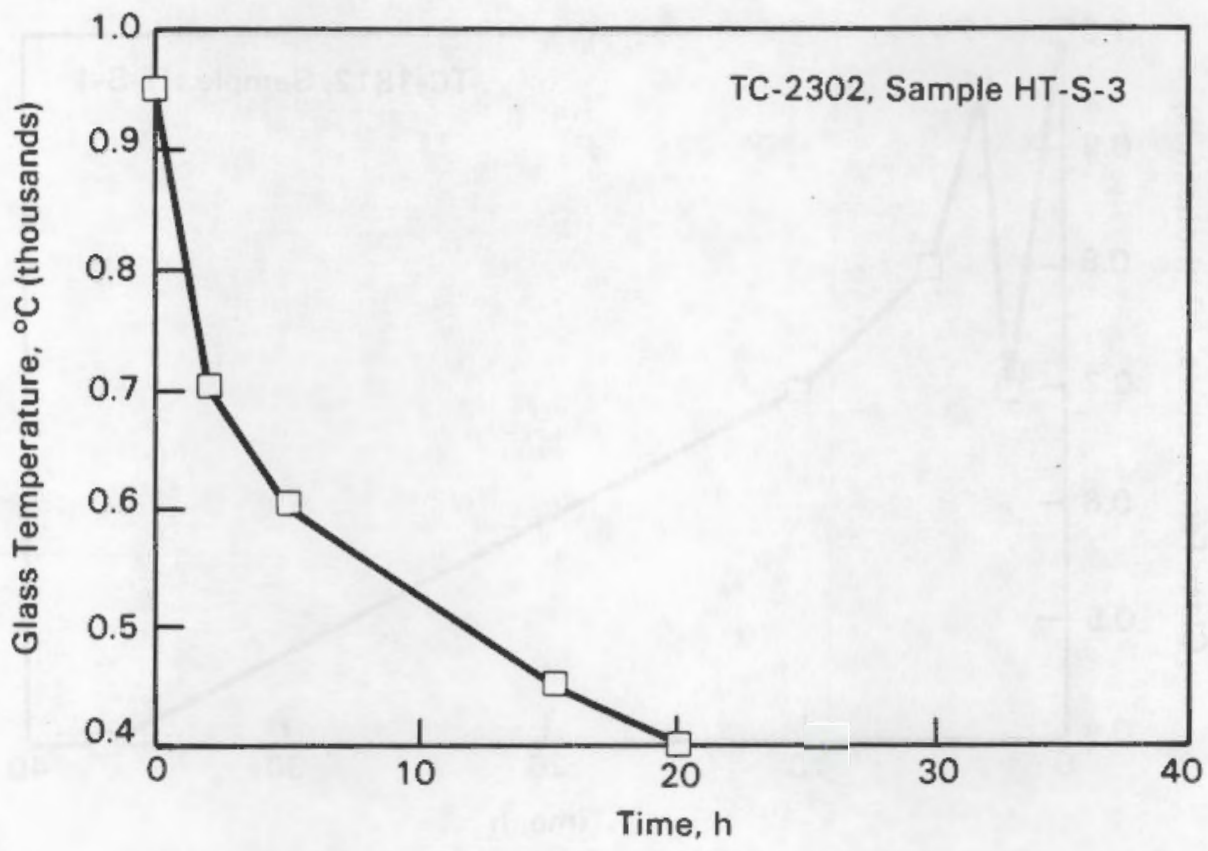

FIGURE 3.3. Sample HT-S-3 Cooling History

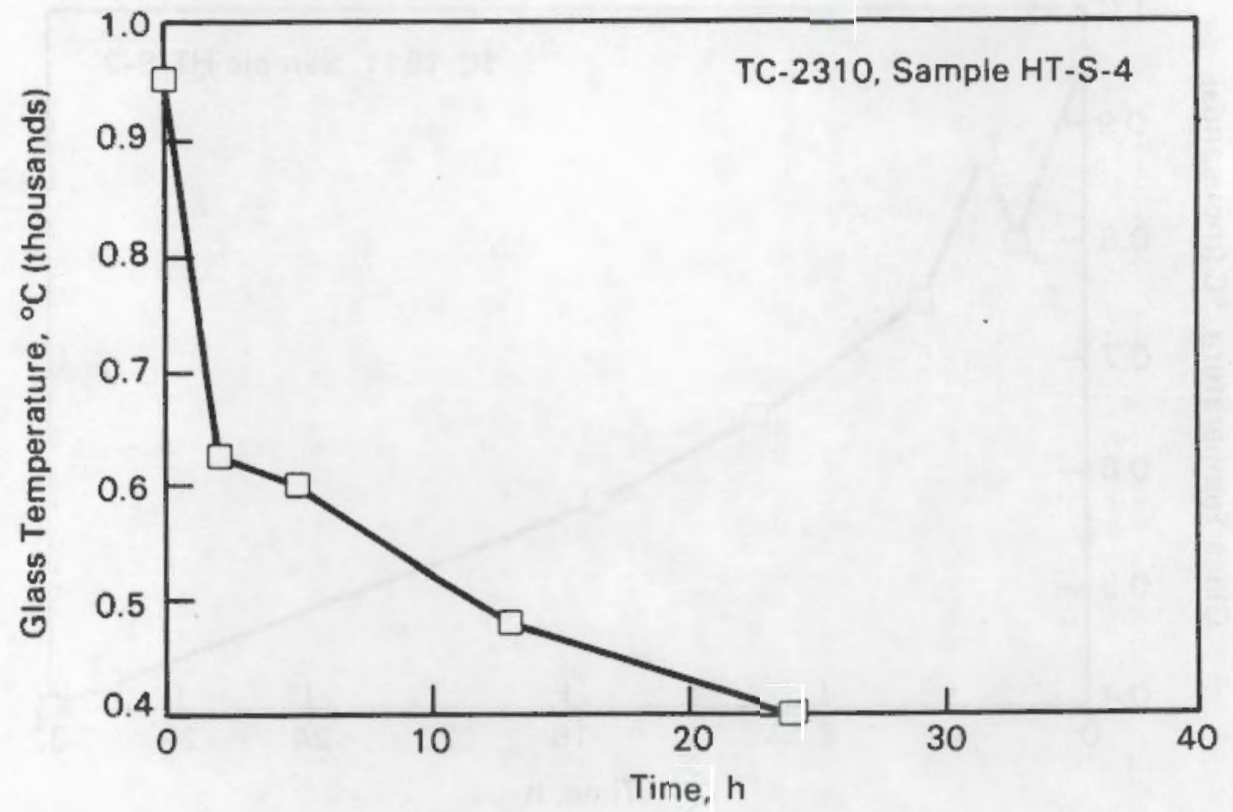

FIGURE 3.4. Sample HT-S-4 Cooling History 


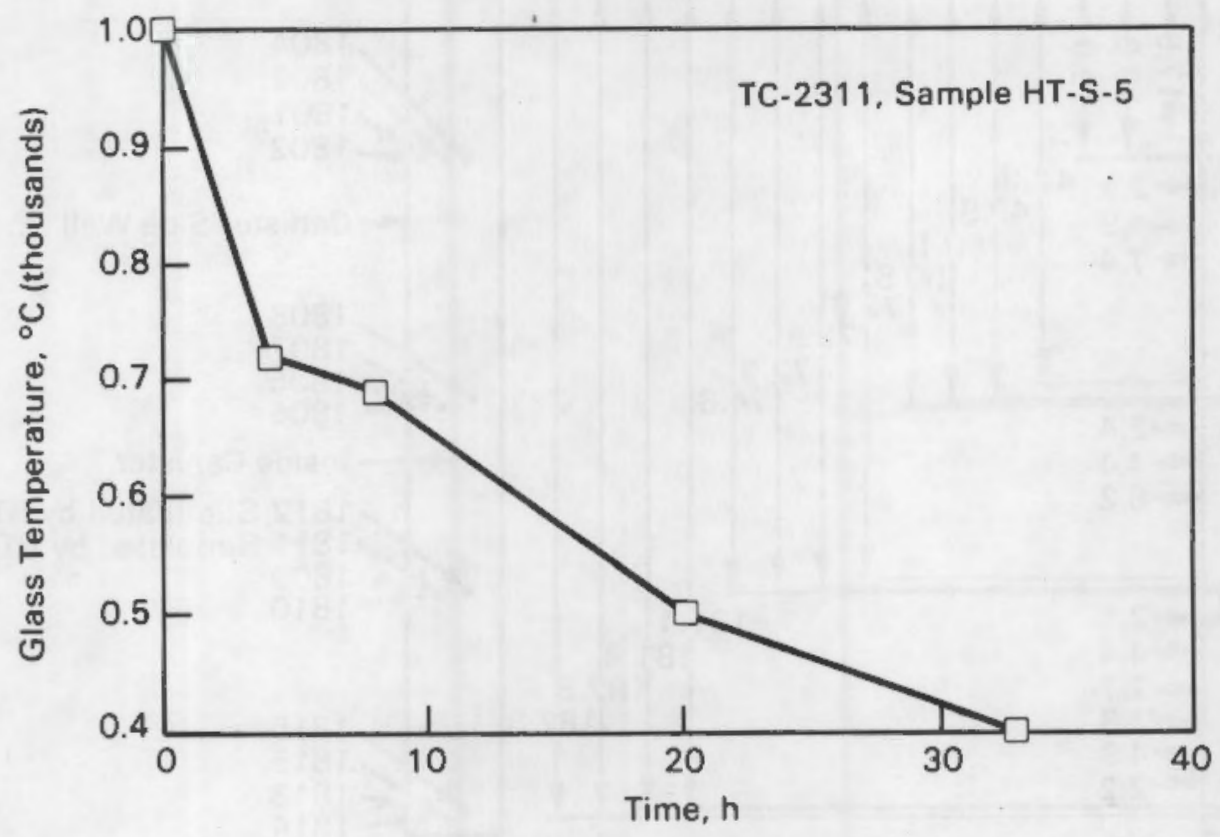

FIGURE 3.5. Sample HT-S-5 Cooling History

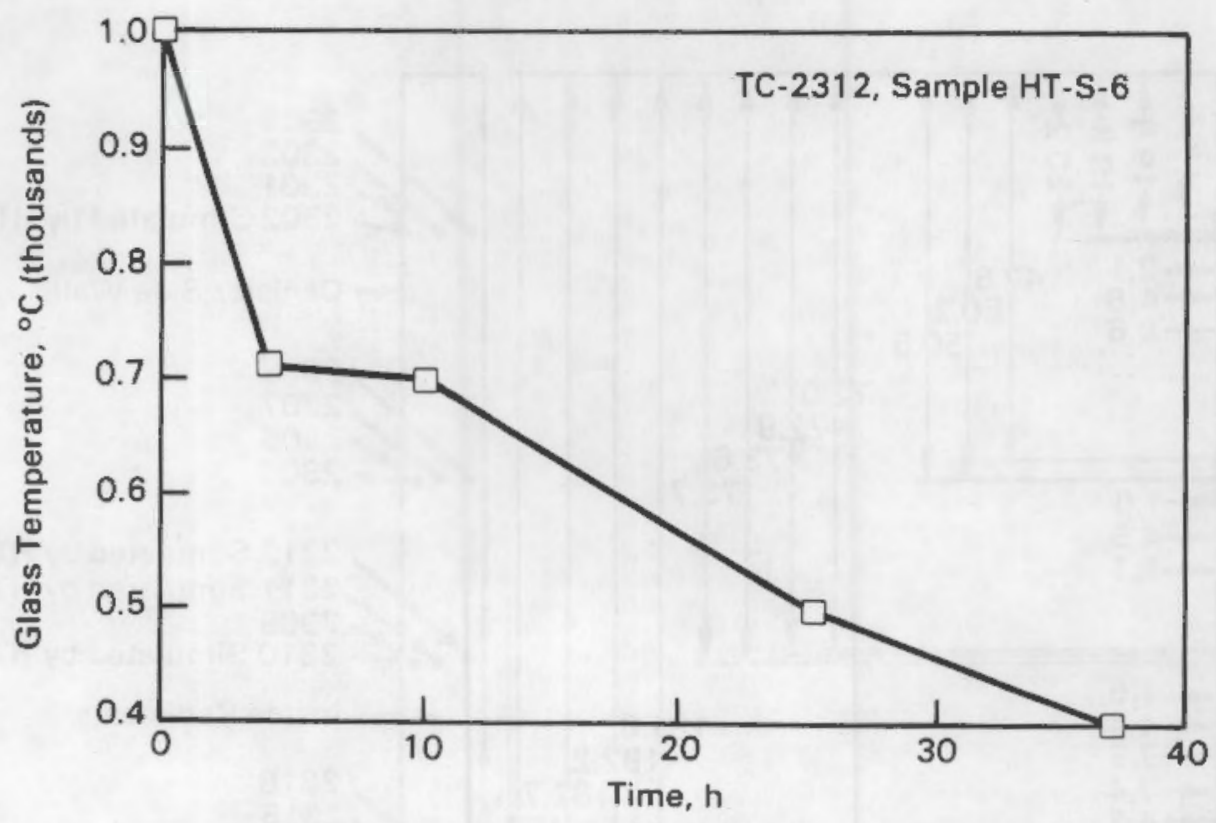

FIGURE 3.6. Sample HT-S-6 Cooling History 


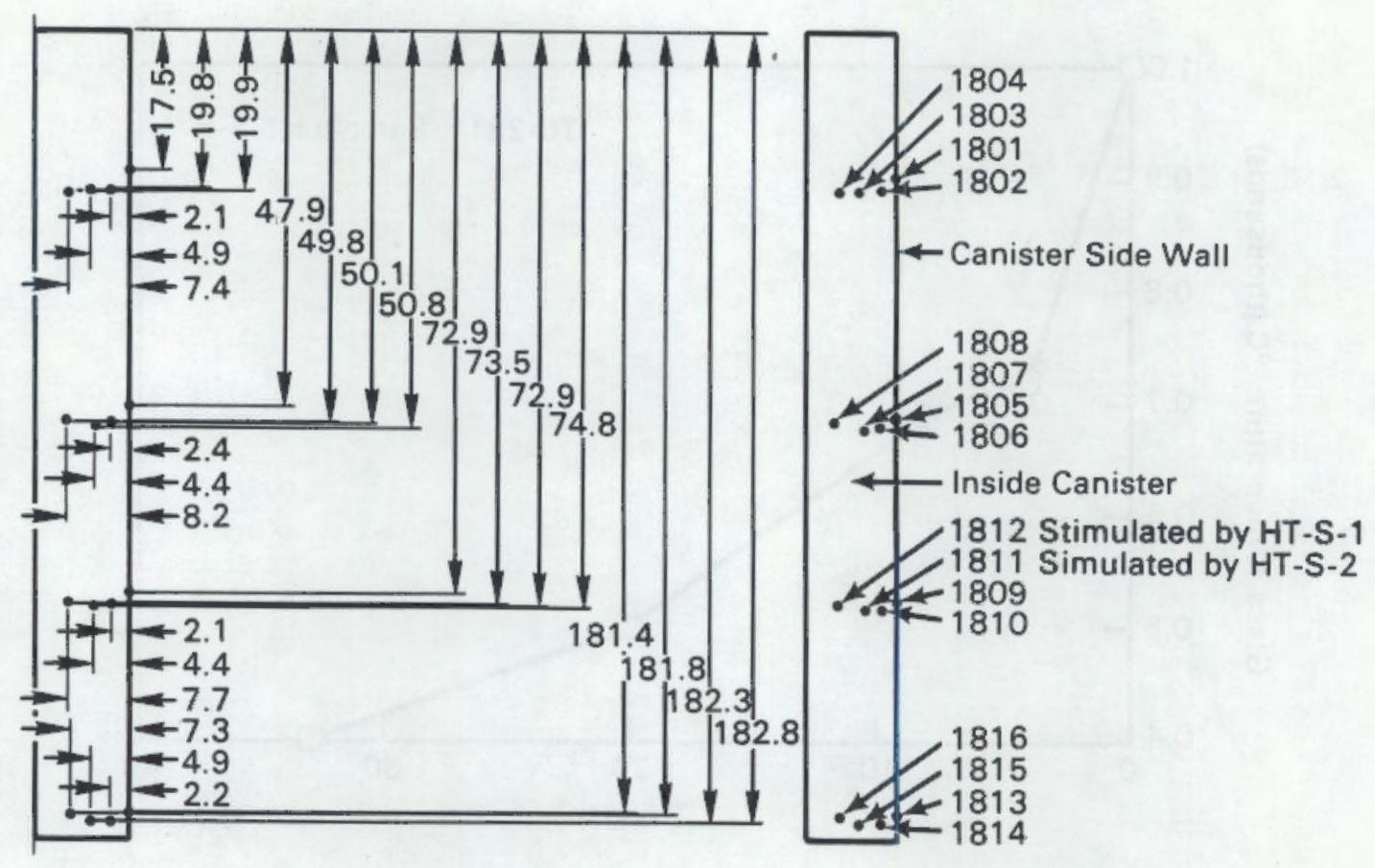

FIGURE 3.7. Thermocouple Locations in Canister TC-18. Simulated by heat-treatment samples HT-S-1 and 2.

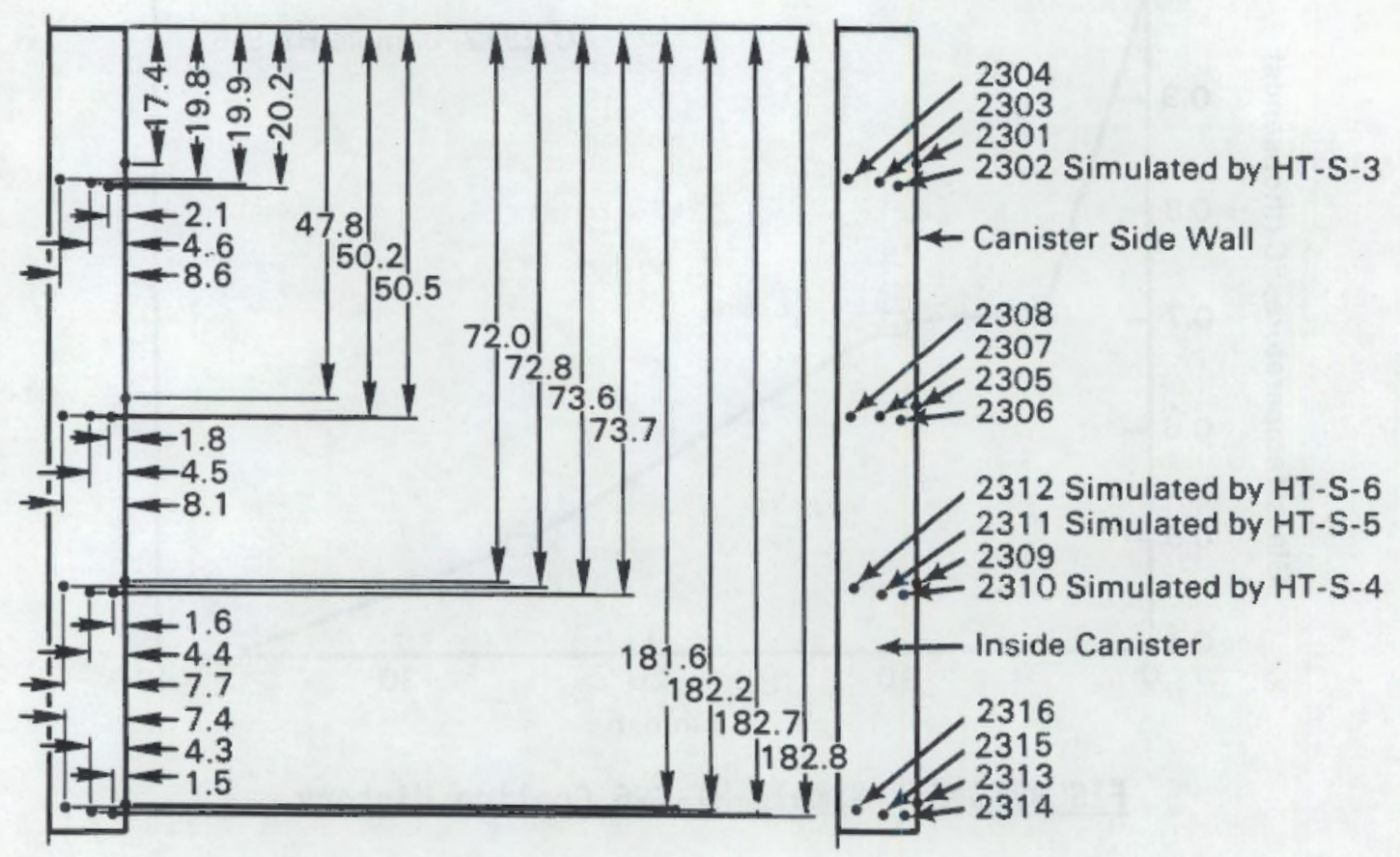

FIGURE 3.8. Thermocouple Locations in Canister TC-23. Simulated by heat-treatment samples HT-S-3, 4, 5, and 6 . 
The cooling scheme used to treat sample HT-S-3 simulates the temperature readings observed approximately $20 \mathrm{in}$. from the top of canister TC-23. This cooling scheme gives the fastest cooling of the six used. Cooling schemes used for samples HT-S-4, 5, and 6 were simulated temperatures observed approximately $30 \mathrm{in}$. from the bottom of canister TC-23.

Six samples of a $1.5 \mathrm{~kg}$ batch of West Valley reference waste glass were heat treated. The composition of the glass is the same as that used in the redox adjustment study. The target oxide and as-analyzed compositions of these glass samples are given in Table 3.10. The glass was treated in the following manner. A specified amount of crushed glass was placed in a fused silica crucible and put in the furnace at $1200^{\circ} \mathrm{C}$. When the glass was in a molten state (after about $20 \mathrm{~min}$ ), the furnace controller program was activated. The temperature of the furnace was monitored over time with a thermocouple with continuous strip chart read-out. The crucible was removed from the furnace at a temperature of rough $7 y 100^{\circ} \mathrm{C}$, allowed to cool to room temperature, then sectioned and a vertical slice removed and polished. The slice was then examined and analyses taken with SEM/EDX and $x$-ray diffraction (XRD). A portion of the remaining glass, not including glass comprising the glass/crucible interface, was crushed and sieved in preparation for leach testing.

\subsubsection{Isothermal Heat Treatments}

West Valley Nuclear Services (WVNS) specified the specific annealing heat treatments to be used in this work. The specified heat treatment test matrix is given in Table 3.11. The matrix consists of five different treatment temperatures and holding times varying from 6 to $240 \mathrm{~h}$. The selection of this matrix was based on work performed at Alfred University.

A total of 15 samples from three $1.25 \mathrm{~kg}$ batches of West Valley reference glass (labeled DG-WV31A, B, and C) were heat treated. The composition of the glass is the same as that used in the simulated canister cooling treatments. Random samples of half of the treated specimens ( 8 samples) were submitted for chemical analysis to determine their compositions. These analyses were used to determine the average compositions of the three glass 
IABLE 3.10. Compositions of S10w Cool Heat Treated Glasses, wt\%

\begin{tabular}{|c|c|c|c|c|c|c|c|}
\hline \multirow[b]{2}{*}{ Oxide } & \multirow[b]{2}{*}{ Terget } & \multicolumn{6}{|c|}{ As-Analyzed ${ }^{(a)}$} \\
\hline & & $\mathrm{HT}-\mathrm{S}-\mathrm{T}$ & $\mathrm{HT}-\mathrm{S}-2$ & $\underline{H T-S-3}$ & HT $-\mathrm{S}-4$ & HIT-S-5 & $\underline{H T-S-6}$ \\
\hline $\mathrm{Al}_{2} \mathrm{O}_{3}$ & 9.99 & 10.60 & 10.32 & 10.41 & 10.37 & 10.33 & 10.35 \\
\hline $\mathrm{B}_{2} \mathrm{O}_{3}$ & 10.69 & 10.81 & 10.93 & 10.82 & 10.87 & 10.96 & 10.90 \\
\hline $\mathrm{BeO}$ & 0.05 & 0.04 & 0.05 & 0.04 & 0.05 & 0.05 & 0.05 \\
\hline $\mathrm{C} \times \mathrm{O}$ & 0.60 & 0.64 & 0.64 & 0.66 & 0.62 & 0.64 & 0.63 \\
\hline $\mathrm{CeO}_{2}$ & 0.07 & 0.07 & 0.07 & 0.07 & 0.07 & 0.07 & 0.07 \\
\hline $\mathrm{Cr}_{2} \mathrm{O}_{3}$ & 0.18 & 0.19 & 0.18 & 0.19 & 0.19 & 0.17 & 0.19 \\
\hline $\mathrm{Cs}_{2} \mathrm{O}$ & 0.08 & 0.08 & 0.07 & 0.07 & 0.06 & 0.07 & 0.07 \\
\hline $\mathrm{Fe}_{2} \mathrm{O}_{3}$ & 12.19 & 11.85 & 11,67 & 11.76 & 11.81 & 11.58 & 11.74 \\
\hline $\mathrm{K}_{2}{ }^{0}$ & 2.44 & 2.30 & 2.33 & 2.42 & 2.20 & 2.43 & 2.21 \\
\hline $\mathrm{Le}_{2} \mathrm{O}_{3}$ & 0.03 & 0.04 & 0.04 & 0.03 & 0.03 & 0.04 & 0.04 \\
\hline$L i_{2} O$ & 2.63 & 2.57 & 2.56 & 2.55 & 2.53 & 2.59 & 2.55 \\
\hline $\operatorname{Mg} 0$ & 1.33 & 1.29 & 1.29 & 1.30 & 1.30 & 1.28 & 1.30 \\
\hline $\mathrm{MnO}_{2}$ & 1.31 & 1.34 & 1.33 & 1.36 & 1.35 & 1.33 & 1.36 \\
\hline $\mathrm{MoO}_{3}$ & 0.01 & 0.01 & 0.01 & 0.01 & 0.01 & 0.01 & 0.01 \\
\hline $\mathrm{He}_{2} \mathrm{O}$ & 9.58 & 9.06 & 9.23 & 9.15 & 9.26 & 9.19 & 9.13 \\
\hline $\mathrm{Nd}_{2} \mathrm{O}_{3}$ & 0.12 & 0.11 & 0.13 & 0.11 & 0.13 & 0.11 & 0.13 \\
\hline Nio & 0.28 & 0.29 & 0.27 & 0.29 & $0.2 B$ & 0.29 & 0.28 \\
\hline $\mathrm{P}_{2} \mathrm{O}_{5}$ & 2.52 & 2.54 & 2.54 & 2.51 & 2.53 & 2.52 & 2.56 \\
\hline $\mathrm{PCD}_{2}$ & 0.01 & 0.01 & 0.01 & 0.01 & 0.01 & 0.01 & 0.01 \\
\hline $\mathrm{Pr}_{6} \mathrm{O}_{11}$ & 0.03 & 0.03 & 0.03 & 0.03 & 0.03 & 0.03 & 0.03 \\
\hline $\mathrm{RhO}_{2}$ & 0.01 & 0.01 & 0.01 & 0.01 & 0.01 & 0.01 & 0.01 \\
\hline $\mathrm{RWO}_{2}$ & 0.09 & 0.12 & 0.13 & 0.12 & 0.13 & 0.11 & 0.13 \\
\hline $\mathrm{SiO}_{2}$ & 39.96 & 41.15 & 41.41 & 41.31 & 41.39 & 41.22 & 41.40 \\
\hline $\mathrm{Sm}_{2} \mathrm{O}_{3}$ & 0.03 & 0.03 & 0.03 & 0.03 & 0.03 & 0.03 & 0.03 \\
\hline $\mathrm{SO}_{3}$ & 0.30 & 0.31 & 0.32 & 0.31 & 0.31 & 0.31 & 0.31 \\
\hline sro & 0.03 & 0.02 & 0.02 & 0.02 & 0.02 & 0.02 & 0.02 \\
\hline Tho, & 3.61 & 2.51 & 2.48 & 2.49 & 2.52 & 2.62 & 2.56 \\
\hline $\mathrm{TiO}_{2}^{2}$ & 0.99 & 0.94 & 0.91 & 0.93 & 0.94 & 0.92 & 0.91 \\
\hline $\mathrm{NO}_{2}$ & 0.56 & 0.49 & 0.49 & 0.49 & 0.49 & 0.51 & 0.50 \\
\hline $\mathrm{Y}_{2} \mathrm{O}_{3}$ & 0.02 & 0.02 & 0.02 & 0.02 & 0.02 & 0.02 & 0.02 \\
\hline $2 \mathrm{rO}_{2}$ & 0.29 & 0.52 & 0.46 & 0.47 & 0.43 & 0.50 & 0.49 \\
\hline TOTAL & 100.02 & $100 . \infty$ & 100.00 & $100 . \infty 0$ & 100.00 & $100 . \infty$ & 100.00 \\
\hline
\end{tabular}

(a) ICP, AA, and laser fluorescence analyses, normalized to $100 x$. 
IABLE 3.11. Isothermal Heat Treatment Test Matrix

\begin{tabular}{lccc}
\multicolumn{1}{c}{ Specimen \# } & Temperature, ${ }^{\circ} \mathrm{C}$ & Holding Iime, $\mathrm{h}$ \\
\cline { 1 - 1 }$-\mathrm{HT}-7-8$ & 500 & & 120,240 \\
HT-S-9 -11 & 600 & $12,48,240$ \\
HT-S-12 -16 & 725 & $6,12,48,120,240$ \\
HT-S-17 -19 & 800 & $12,48,240$ \\
HT-S-20 -21 & 900 & 120,240 \\
HT-S-22 (Test Standard) & 500 & 2
\end{tabular}

batches. No volatility losses of the specimen glasses or other compositional changes due to the heat treatments were observed. The target oxide and asanalyzed compositions of these glass batches are given in Table 3.12.

The glass was treated in the following manner. A portion of crushed $\mathrm{glass}$ was placed in a covered fused silica crucible and put in the furnace at $1200^{\circ} \mathrm{C}$. When the glass was in a molten state (after about 20 minutes), the crucible was removed and placed in a heat-treatment oven heated to the specified temperature. The oven temperature was monitored daily. The crucible remained in the oven for a specified holding time, then was removed and annealed for $2 \mathrm{~h}$ at $500^{\circ} \mathrm{C}$ in an annealing oven. After $2 \mathrm{~h}$ had passed, the oven was turned off and allowed to cool over night. The crucible was removed from the oven, then sectioned and a vertical slice was removed and polished. The slice was analyzed with XRD and SEM/EDX. A test standard, HT-S-22, was prepared in the manner described above except that it was not heat treated prior to the $500^{\circ} \mathrm{C}$ anneal.

A portion of each heat-treated glass, not including glass comprising the glass/crucible interface, was crushed and sieved in preparation for 7-day, MCC -3 leach testing.

\subsection{GROUNDWATER LEACH TESTING}

One West Valley reference glass was leach tested in four different groundwaters. The groundwaters used represent repository groundwaters. 
IABLE 3.12. Compositions of DG-WV31 Batches, wt\%

\begin{tabular}{|c|c|c|c|c|}
\hline \multirow[b]{2}{*}{ Oxide } & \multirow[b]{2}{*}{ Target } & \multicolumn{3}{|c|}{ As-Analyzed (a) } \\
\hline & & Batch $A^{(b)}$ & Batch $\mathrm{B}^{(\mathrm{C})}$ & Batch C \\
\hline $\begin{array}{l}\mathrm{Al}_{2} \mathrm{O}_{3} \\
\mathrm{~B}_{2} \mathrm{O}_{3} \\
\mathrm{BaO} \\
\mathrm{CaO} \\
\mathrm{CeO} \mathrm{O}_{2}\end{array}$ & $\begin{array}{r}9.99 \\
10.69 \\
0.05 \\
0.60 \\
0.07\end{array}$ & $\begin{array}{r}11.10 \\
10.53 \\
0.05 \\
0.77 \\
0.00\end{array}$ & $\begin{array}{r}10.99 \\
10.71 \\
0.05 \\
0.63 \\
0.03\end{array}$ & $\begin{array}{r}11.14 \\
10.32 \\
0.05 \\
0.61 \\
0.06\end{array}$ \\
\hline $\begin{array}{l}\mathrm{Cr}_{2} \mathrm{O}_{3} \\
\mathrm{Cs}_{2} \mathrm{O} \\
\mathrm{CuO} \\
\mathrm{Fe}_{2} \mathrm{O}_{3} \\
\mathrm{~K}_{2} \mathrm{O} \\
\mathrm{La}_{2} \mathrm{O}_{3}\end{array}$ & $\begin{array}{r}0.18 \\
0.08 \\
0.00 \\
12.19 \\
2.44 \\
0.03\end{array}$ & $\begin{array}{r}0.18 \\
0.06 \\
0.01 \\
11.74 \\
2.76 \\
0.03\end{array}$ & $\begin{array}{r}0.18 \\
0.06 \\
0.01 \\
11.93 \\
2.74 \\
0.03\end{array}$ & $\begin{array}{r}0.17 \\
0.06 \\
0.00 \\
11.65 \\
3.04 \\
0.04\end{array}$ \\
\hline $\begin{array}{l}\mathrm{Li}_{2} \mathrm{O} \\
\mathrm{MgO} \\
\mathrm{MnO}_{2} \\
\mathrm{MoO}_{3} \\
\mathrm{Na}_{2} \mathrm{O}\end{array}$ & $\begin{array}{l}2.63 \\
1.33 \\
1.31 \\
0.01 \\
9.58\end{array}$ & $\begin{array}{l}2.55 \\
1.25 \\
1.2 \mathrm{~B} \\
0.00 \\
9.55\end{array}$ & $\begin{array}{l}2.56 \\
1.25 \\
1.31 \\
0.00 \\
9.47\end{array}$ & $\begin{array}{l}2.50 \\
1.29 \\
1.28 \\
0.00 \\
9.24\end{array}$ \\
\hline $\begin{array}{l}\mathrm{Nd}_{2} \mathrm{O}_{3} \\
\mathrm{NiO} \\
\mathrm{P}_{2} \mathrm{O}_{5} \\
\mathrm{PdO}_{2} \\
\mathrm{Pr}_{6} \mathrm{O}_{11} \\
\mathrm{RhO}_{2}\end{array}$ & $\begin{array}{l}0.12 \\
0.28 \\
2.52 \\
0.01 \\
0.03 \\
0.01\end{array}$ & $\begin{array}{l}0.12 \\
0.31 \\
2.52 \\
0.01 \\
0.03 \\
0.01\end{array}$ & $\begin{array}{l}0.12 \\
0.34 \\
2.54 \\
0.01 \\
0.03 \\
0.01\end{array}$ & $\begin{array}{l}0.14 \\
0.32 \\
2.56 \\
0.01 \\
0.03 \\
0.01\end{array}$ \\
\hline $\begin{array}{l}\mathrm{RuO}_{2} \\
\mathrm{SiO}_{2} \\
\mathrm{Sm}_{2} \mathrm{O}_{3} \\
\mathrm{SO}_{3} \\
\mathrm{SrO}\end{array}$ & $\begin{array}{r}0.08 \\
39.96 \\
0.03 \\
0.30 \\
0.03\end{array}$ & $\begin{array}{r}0.08 \\
39.89 \\
0.03 \\
0.30 \\
0.03\end{array}$ & $\begin{array}{r}0.08 \\
40.39 \\
0.03 \\
0.30 \\
0.03\end{array}$ & $\begin{array}{r}0.08 \\
39.77 \\
0.03 \\
0.31 \\
0.03\end{array}$ \\
\hline $\begin{array}{l}\mathrm{ThO}_{2} \\
\mathrm{TiO}_{2} \\
\mathrm{WO}_{2} \\
\mathrm{Y}_{2} \mathrm{O}_{3} \\
\mathrm{ZrO}_{2}\end{array}$ & $\begin{array}{l}3.61 \\
0.99 \\
0.56 \\
0.02 \\
0.29\end{array}$ & $\begin{array}{l}2.68 \\
0.93 \\
0.51 \\
0.02 \\
0.66\end{array}$ & $\begin{array}{l}2.33 \\
0.92 \\
0.45 \\
0.02 \\
0.47\end{array}$ & $\begin{array}{l}3.28 \\
0.92 \\
0.51 \\
0.02 \\
0.51\end{array}$ \\
\hline TOTAL & 100.02 & 100.00 & 100.00 & 100.00 \\
\hline
\end{tabular}

(a) ICP, AA, and laser fluorescence analyses, normalized to $100 \%$.

(b) Average of 3 analyses

(c) Average of 4 analyses 
Leach testing was done to determine the effect of different types of repository groundwaters on the reference glass durability.

\subsubsection{Groundwater Descriptions}

Four leachants representing repository groundwaters were used in this study. Their compositions are given in Tables 3.13 through 3.16. Dne of these, J-13, is actual groundwater recovered from a well at the Yucca Mountain repository site selected by DDE for site characterization. The

TABLE 3.13. Composition of J-13 Wel1 Water--Tuff Groundwater Used in Groundwater Study

\begin{tabular}{|c|c|c|c|}
\hline Species & $\begin{array}{c}\text { As } \\
\text { Analyzed (a) }\end{array}$ & $\begin{array}{c}\text { As } \\
\text { Analyzed (b) }\end{array}$ & Blank $(c)$ \\
\hline $\begin{array}{l}\mathrm{B} \\
\mathrm{Na} \\
\mathrm{K} \\
\mathrm{Ca} \\
\mathrm{Si} \\
\mathrm{Mg}\end{array}$ & $\begin{array}{r}0.20 \\
48.20 \\
6.64 \\
13.30 \\
32.60 \\
2.17\end{array}$ & $\begin{array}{r}0.132 \\
44.70 \\
5.11 \\
12.70 \\
27.10 \\
1.92\end{array}$ & $\begin{array}{c}0.16^{\star} \\
44.90^{\star} \\
4.80^{\star} \\
12.60 \\
27.60^{\star} \\
1.33\end{array}$ \\
\hline $\begin{array}{l}\mathrm{F} \\
\mathrm{Cl} \\
\mathrm{SO}_{4} \\
\left.\mathrm{NO}_{3} \mathrm{~d}\right) \\
\mathrm{ICld})\end{array}$ & $\begin{array}{r}2.30 \\
7.09 \\
17.20 \\
7.64 \\
24.20\end{array}$ & $\begin{array}{c}2.20 \\
0.21 \\
18.70 \\
9.69 \\
\text { NA (e) }\end{array}$ & $\begin{array}{r}2.50 \\
7.10 \\
17.00 \\
8.50 \\
\text { NA }\end{array}$ \\
\hline $\mathrm{pH}$ & 8.12 & $8.20(f)$ & $8.26(g)$ \\
\hline
\end{tabular}

(a) ICP, IC and organic $C$ analyses reported by material custodian.

(b) Averages, reported by Oversby, 1985.

(c) ICP and IC analyses of test blank sample. Concentrations marked with an asterisk were used for correction of test results.

(d) Inorganic carbon.

(e) Not available.

(f) $\mathrm{pH}$ measured immediately preceding test.

(g) $\mathrm{pH}$ measured at test termination. 
IABLE 3.14. Composition of PBB1 Brine Used in Groundwater Study

Concentration, ppm

\begin{tabular}{|c|c|c|}
\hline Species & Target & As Analyzed (a) \\
\hline $\begin{array}{l}\mathrm{Na} \\
\mathrm{Ca} \\
\mathrm{Mg} \\
\mathrm{K} \\
\mathrm{Sr}\end{array}$ & $\begin{array}{r}124000.0 \\
1600.0 \\
134.0 \\
39.0 \\
35.0\end{array}$ & $\begin{array}{r}124000.0 \\
1300.0 \\
104.0 \\
87.9 \\
13.7\end{array}$ \\
\hline $\begin{array}{l}\mathrm{Cl} \\
\mathrm{SO}_{4} \\
\mathrm{Br} \\
\mathrm{HCO}_{3}\end{array}$ & $\begin{array}{r}192000.0 \\
3840.0 \\
32.0 \\
30.5\end{array}$ & $\begin{array}{r}185000.0 \\
3500.0 \\
42.0 \\
16.2\end{array}$ \\
\hline
\end{tabular}

(a) ICP and ion chromatograph (IC) analyses.

TABLE 15. Composition of PBB3 Brine Used in Groundwater Study

Concentration, ppm

\begin{tabular}{lccc}
\cline { 2 - 3 } Species & Target & & As Analyzed (a) \\
$\mathrm{Na}$ & $25000 \pm 5000$ & & 22900 \\
$\mathrm{Ca}$ & $18700 \pm 2000$ & & 18500 \\
$\mathrm{Mg}$ & $62500 \pm 6000$ & 56600 \\
$\mathrm{~K}$ & $11000 \pm 2000$ & 12100 \\
$\mathrm{Cl}$ & $240000 \pm 20000$ & 243000 \\
$\mathrm{SO}_{4}$ & $250 \pm 150$ & 209 \\
$\mathrm{Br}$ & $3400 \pm 700$ & 3550
\end{tabular}

(a) ICP and IC analyses.

other three are synthetic groundwaters, prepared with specific compositions, used in testing the effects of these repository groundwaters on the nuclear waste package. Two of the synthetic groundwaters, PBB1 and PBB3, represent groundwater generated by a bedded salt site. The other, GR-4, represents basalt groundwater. 
IABLE 3.16. Composition of GR-4 - Basalt Groundwater Used in Groundwater Study

\begin{tabular}{|c|c|c|c|}
\hline Species & Target & As Analyzed (a) & Blank ${ }^{(b)}$ \\
\hline $\begin{array}{l}\mathrm{Na} \\
\mathrm{K} \\
\mathrm{Ca} \\
\mathrm{Si}\end{array}$ & $\begin{array}{r}334.0 \\
13.8 \\
2.2 \\
45.0\end{array}$ & $\begin{array}{c}364.5 \\
14.15 \\
2.22 \\
43.45\end{array}$ & $\begin{array}{c}349.5^{\star} \\
13.8^{\star} \\
2.2 \\
36.3 *\end{array}$ \\
\hline $\begin{array}{l}\mathrm{F} \\
\mathrm{Cl}_{1} \\
\mathrm{SO}_{4}(\mathrm{c}) \\
\mathrm{IC}\end{array}$ & $\begin{array}{r}19.9 \\
405.0 \\
4.0 \\
18.1\end{array}$ & $\begin{array}{c}19.9 \\
409.85 \\
4.2 \\
19.25\end{array}$ & $\begin{array}{r}20.0 \\
420.0 \\
N_{A}(d)^{3.8}\end{array}$ \\
\hline $\mathrm{pH}$ & 9.70 & $10.18(\mathrm{e})$ & $9.66(f)$ \\
\hline
\end{tabular}

\footnotetext{
(a) ICP and IC analyses - information supplied by material custodian.

(b) ICP and IC analyses of test blank sample. Concentrations marked with an asterisk were used for correction of test results.

(c) lnorganic carbon.

(d) Information not available.

(e) $\mathrm{pH}$ measured immediately preceding test.

(f) $\mathrm{pH}$ measured at test termination at $25^{\circ} \mathrm{C}$.
}

The J-13 water is obtained from the J-13 well located on the Yucca Mountain site in Nevada. The reference repository horizon is a welded, devitrified portion of the Topopah Spring Member of the Paintbrush Tuff. The water from well J-13 has been adopted as a reference water chemistry for experimental work (Oversby 1985). The composition of J-13 water used in this study is given in Table 3.13.

PBB1 and PBB3 are synthetic brines developed to support PNL laboratory work performed to determine the general corrosion resistance of waste package components in contact with Permian Basin salt and brine derived therefrom. PBB1 represents the brine resulting from dissolution of salt core samples from a Permian Basin salt horizon considered representative of a bedded-saltsite repository. The specific salt core samples were obtained from G. Friemel Hole No. 1 near Amarillo, Texas, and are representative of the Cycle 4 salt horizon in that region. PBB3 represents an inclusion brine 
chemistry, i.e., a brine that exists in inclusions in a bedded salt as opposed to brines resulting from a hypothetical water intrusion, such as PBBl. The chemical composition of PBB3 was supplied to PNL by the Salt Repository Project (SRP) in December 1983. The compositions of the PB81 and PBB3 brines used in this study are given in Tables 3.14 and 3.15, respectively.

GR-4 water is chemically representative of groundwater found in the reference repository location (RRL) area of the Grande Ronde basalt formation underlying the Hanford Site near Richland, Washington (Dill et al. 1985). This reference synthetic groundwater was developed to be used in tests including the interaction of groundwater with basalt rock, waste forms, and engineered barriers. To evaluate the results of these tests, it is imperative that the experiments be carried out using a common groundwater of known stable constituents. Because of the instability of the water system and logistical problems associated with collecting and shipping large volumes of groundwater over long distances, it was deemed necessary to develop a synthetic groundwater "recipe." The composition of this water is given in Table 3.16.

\subsubsection{Leach Testing and Blank Correction}

Four samples of a batch of West Valley reference waste glass were leach tested in the groundwaters. The composition of the glass is the same as that used in the redox adjustment and heat treatment studies. The target oxide and as-analyzed compositions of the glass are given in Table 3.17.

The concentrations of the leachates were corrected with test blanks. This was done with the brine solutions (PBB1 and PBB3) by the analytical laboratory with matrix matching. A sample of the clean brine was run with a sample of the leachate brine for the solution matrix matching. The results reported by the laboratory reflected only those elements which were higher in concentration in the leachate than the clean brine. The concentrations of the tuff and basalt groundwater leachates were corrected by subtracting the concentration of elements found in the blank from the leachate concentrations. This could not be done for ca concentration in basalt groundwater nor 
IABLE 3.17. Composition of West Valley Reference Glass Used in Groundwater Effects Study, wt\%

\begin{tabular}{|c|c|c|}
\hline Oxides & Target & $\begin{array}{c}\text { As } \\
\text { Analyzed (a) }\end{array}$ \\
\hline $\begin{array}{l}\mathrm{Al}_{2} \mathrm{O}_{3} \\
\mathrm{~B}_{2} \mathrm{O}_{3} \\
\mathrm{BaO} \\
\mathrm{CaO} \\
\mathrm{CeO} \mathrm{O}_{2}\end{array}$ & $\begin{array}{r}9.99 \\
10.69 \\
0.05 \\
0.60 \\
0.07\end{array}$ & $\begin{array}{r}11.32 \\
10.72 \\
0.05 \\
0.58 \\
0.07\end{array}$ \\
\hline $\begin{array}{l}\mathrm{Cr}_{2} \mathrm{O}_{3} \\
\mathrm{Cs}_{2} \mathrm{O} \\
\mathrm{CuO} \\
\mathrm{Fe}_{2} \mathrm{O}_{3} \\
\mathrm{~K}_{2} \mathrm{O}\end{array}$ & $\begin{array}{r}0.18 \\
0.08 \\
0.00 \\
12.19 \\
2.44\end{array}$ & $\begin{array}{r}0.00 \\
0.05 \\
0.03 \\
11.52 \\
2.79\end{array}$ \\
\hline $\begin{array}{l}\mathrm{La}_{2} \mathrm{O}_{3} \\
\mathrm{Li}_{2} \mathrm{O}^{2} \\
\mathrm{MgO} \\
\mathrm{MnO}_{2} \\
\mathrm{MoO}_{3}\end{array}$ & $\begin{array}{l}0.03 \\
2.63 \\
1.33 \\
1.31 \\
0.01\end{array}$ & $\begin{array}{l}0.03 \\
2.61 \\
1.26 \\
1.21 \\
0.01\end{array}$ \\
\hline $\begin{array}{l}\mathrm{Na}_{2} \mathrm{O} \\
\mathrm{Nd}_{2} \mathrm{O}_{3} \\
\mathrm{NiO} \\
\mathrm{P}_{2} \mathrm{O}_{5} \\
\mathrm{PdO}_{2}\end{array}$ & $\begin{array}{l}9.58 \\
0.12 \\
0.28 \\
2.52 \\
0.01\end{array}$ & $\begin{array}{l}8.99 \\
0.12 \\
0.00 \\
2.55 \\
0.01\end{array}$ \\
\hline $\begin{array}{l}\mathrm{Pr}_{6} \mathrm{O}_{11} \\
\mathrm{RhO}_{2} \\
\mathrm{RuO}_{2} \\
\mathrm{SiO}_{2} \\
\mathrm{Sm}_{2} \mathrm{O}_{3}\end{array}$ & $\begin{array}{r}0.03 \\
0.01 \\
0.08 \\
39.96 \\
0.03\end{array}$ & $\begin{array}{r}0.03 \\
0.01 \\
0.06 \\
40.62 \\
0.03\end{array}$ \\
\hline $\begin{array}{l}\mathrm{SO}_{3} \\
\mathrm{SrO} \\
\mathrm{ThO}_{2} \\
\mathrm{TiO}_{2} \\
\mathrm{UO}_{2} \\
\mathrm{Y}_{2} \mathrm{O}_{3} \\
\mathrm{ZrO}_{2}\end{array}$ & $\begin{array}{l}0.30 \\
0.03 \\
3.61 \\
0.99 \\
0.56 \\
0.02 \\
0.29\end{array}$ & $\begin{array}{l}0.30 \\
0.03 \\
3.04 \\
0.96 \\
0.52 \\
0.02 \\
0.47\end{array}$ \\
\hline TOTAL & 100.02 & 100.00 \\
\hline
\end{tabular}

(a) ICP, AA, and Taser fluorescence analyses, normalized to $100 \%$. 
Ca and $\mathrm{Mg}$ concentrations in tuff groundwater as these concentrations were higher in the blanks than in the leachates. Both of these must have formed compounds during the leaching process which precipitated from the leaching solution. Tuff and basalt groundwater test blank compositions are given in Tables 3.13 and 3.16 , respectively. 


\subsection{RESULTS AND DISCUSSION}

\subsection{COMPOSITION EFFECTS - FY 1987}

The results from the FY 1987 MCC-3 and MCC-1 leach tests of glasses DGWV1 through DG-WV8 and DG-WV15 through DG-WV30 show how variations in glass composition relate to variations in glass durability. The test results are described in the following sections.

\subsubsection{First Set of FY 1987 Glasses--DG-WV1 Through DG-WV8}

\section{MCC-3, 7-day Leach Testing Results}

Table 4.1 lists the normalized elemental mass releases of $\mathrm{B}, \mathrm{Cs}, \mathrm{Na}, \mathrm{Si}$, Th, $U$, and those elements whose oxide contributed at least 1 wt\% of the glass composition. Each value given represents the average obtained from three replicate tests. The three replicate tests were performed at the same time under the same conditions, and the resulting leachates were chemically analyzed at the same time under the same conditions. Hence the replicates only include short-term variations in the leach testing and leachate analysis processes.

The analysis of these releases shows that the chemical durabilities of the reference glass DG-WV1, and the glass containing noble metal (Rh, Ru, Pd) oxides, DG-WV2, are essentially identical. The least chemically durable glass appears to be the "high $\mathrm{Na}_{2} \mathrm{O}$ glass (DG-WV4), as was expected (increasing amounts of alkali decreases chemical durability). The glasses containing relatively low amounts of $\mathrm{Al}_{2} \mathrm{O}_{3}$ (DG-WV3 and DG-WV5) are less chemically durable than the reference glass, as was also expected (increasing amounts of $\mathrm{Al}_{2} \mathrm{O}_{3}$ increases chemical durability). The "high" $\mathrm{P}_{2} \mathrm{O}_{5}$ and $\mathrm{ThO}_{2}$ (DG-WV6 and DG-WV7) and "low" $\mathrm{B}_{2} \mathrm{O}_{3}$ glasses (DG-WV8) appear to be as chemically durable as the reference glass. This indicates that these variations in $\mathrm{P}_{2} \mathrm{O}_{5}, \mathrm{ThO}_{2}$, and $\mathrm{B}_{2} \mathrm{O}_{3}$ have little, if any, real effect on the product chemical durability.

Graphical representations of $B$ and $S i$ releases are given in Figure 4.1. The error bars represent short-term experimental error of \pm two standard deviations (sds). The sds are based on replicate tests performed at the same time and do not include the time-related component of variability. 
TABLE 4.1. Average Normalized Mass Releases of Glasses DG-WV1 Through DG-WV8 (7-day MCC-3, Deaerated DIW, $90^{\circ} \mathrm{C}$ ), $\mathrm{g} / \mathrm{m}^{2}$

\begin{tabular}{|c|c|c|c|c|c|c|c|c|}
\hline \multirow[b]{2}{*}{ Element } & \multicolumn{8}{|c|}{ Average Nonnal ized Mass Release $\left(\mathrm{g} / \mathrm{m}^{2}\right)$} \\
\hline & $\underline{D G-W N 1}$ & $\underline{D G-W N 2}$ & $\underline{D G-W \sqrt{3}}$ & $\underline{D G-W / 4}$ & $\underline{D G-W N 5}$ & $\underline{D G-W 6}$ & $\underline{D G-L N 7}$ & DG-WWB \\
\hline Al & 0.106 & 0.109 & 0.098 & 0.110 & 0.097 & 0.115 & 0.109 & 0.113 \\
\hline B & 0.186 & 0.191 & 0.237 & 0.239 & 0.229 & 0.188 & 0.188 & 0.187 \\
\hline cs & 0.104 & 0.092 & 0.137 & 0.092 & 0.082 & 0.093 & 0.120 & 0.040 \\
\hline $\mathrm{Fe}$ & 0.002 & 0.003 & 0.004 & 0.003 & 0.003 & 0.003 & 0.003 & 0.003 \\
\hline K. & 0.021 & 0.022 & 0.043 & 0.014 & 0.022 & 0.006 & 0.033 & 0.026 \\
\hline Li & 0.301 & 0.305 & 0.300 & 0.294 & 0.328 & 0.301 & 0.323 & 0.319 \\
\hline Mg & 0.000 & 0.000 & 0.008 & 0.000 & 0.000 & 0.000 & 0.000 & 0.005 \\
\hline Mn & 0.001 & 0.003 & 0.003 & 0.002 & 0.002 & 0.002 & 0.002 & 0.003 \\
\hline $\mathrm{Na}$ & 0.158 & 0.163 & 0.218 & 0.239 & 0.204 & 0.155 & 0.170 & 0.176 \\
\hline r & 0.105 & 0.107 & 0.196 & 0.182 & 0.147 & 0.097 & 0.108 & 0.133 \\
\hline si & 0.116 & 0.117 & 0.129 & 0.123 & 0.127 & 0.123 & 0.119 & 0.118 \\
\hline Th & 0.001 & 0.002 & 0.001 & 0.001 & 0.001 & 0.002 & 0.001 & 0.002 \\
\hline Ti & 0.001 & 0.002 & 0.002 & 0.001 & 0.001 & 0.002 & 0.001 & 0.002 \\
\hline$u$ & 0.026 & 0.031 & 0.031 & 0.029 & 0.030 & 0.033 & 0.038 & 0.037 \\
\hline $\mathrm{pH}^{(a)}$ & 9.15 & 9.27 & 9.41 & 9.22 & 9.37 & 9.02 & 8.78 & 9.33 \\
\hline
\end{tabular}

(a) $\mathrm{pH}$ measured at test termination at $25^{\circ} \mathrm{C}$.

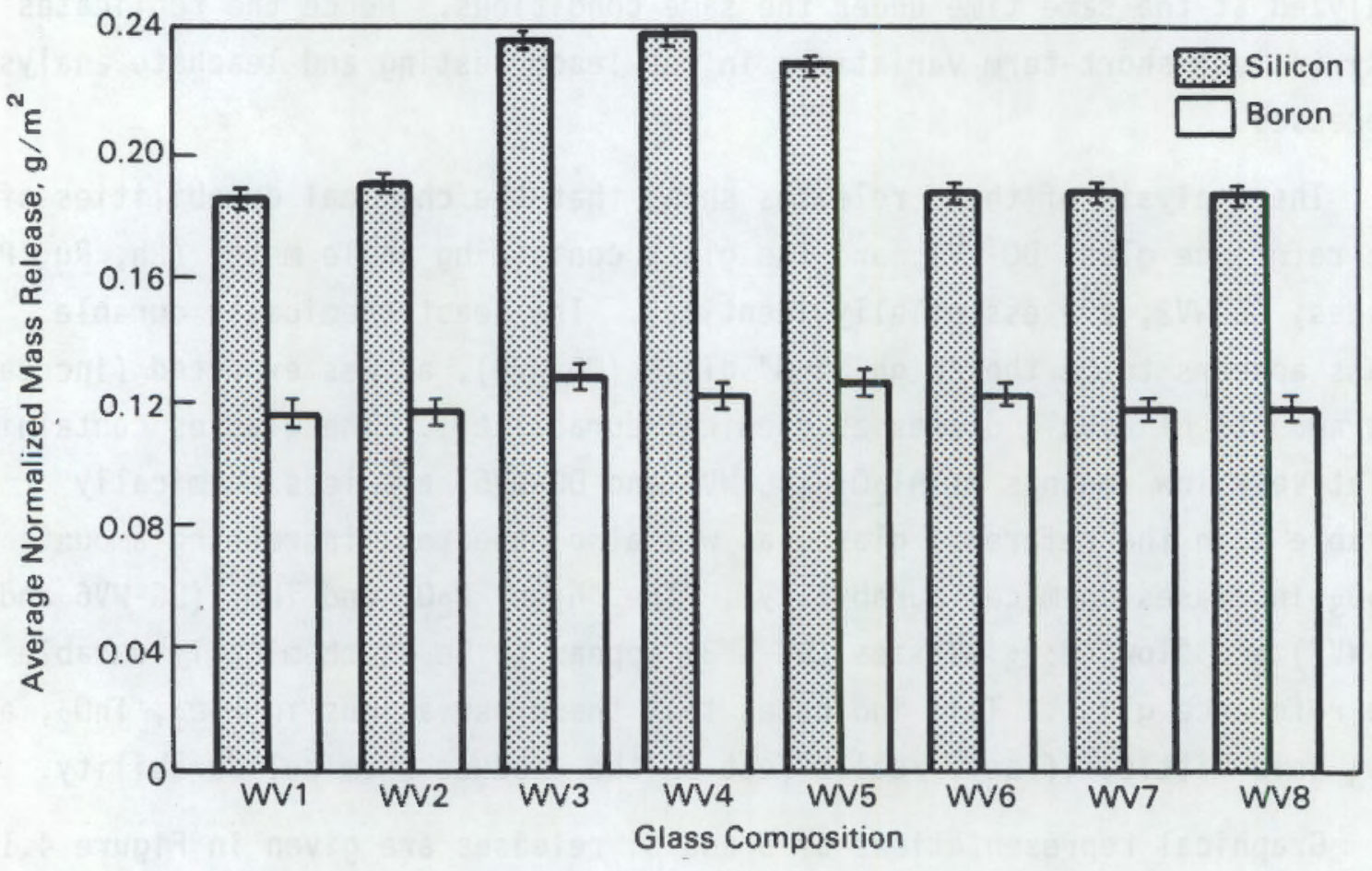

FIGURE 4.1. Comparison of Boron and Silicon Normalized Mass Releases from DG-WV1 Through DG-WV8. Modified MCC -3 test, $90^{\circ} \mathrm{C}$, deaerated deionized water, 7-day. 
Figure 4.1 shows that $S i$ release is relatively consistent among each glass tested, indicating that its solubility limit was reached during the test period. The B release data show that DG-WV3, DG-WV4, and DG-WV5 are the least chemically durable, with the other five compositions exhibiting greater chemical durability.

\section{MCC-1, 28-day Leach Testing Results}

G1asses DG-WV1 through DG-WV8 were also subjected to 28-day MCC-1 leach testing. Table 4.2 lists the normalized elemental mass releases of $B, C_{S}$, $\mathrm{Na}, \mathrm{Si}, \mathrm{Th}, \mathrm{U}$, and those elements whose oxide contributed at least $1 \mathrm{wt} \%$ of the glass composition. Each value given represents the average obtained from three replicate tests. Graphical representations of $\mathrm{Si}$ and $\mathrm{B}$ releases are given in Figure 4.2. The error bars represent \pm two sds. The sds are based on replicate tests performed at the same time and do not include the timerelated component of variability. The results are similar to those observed from MCC -3 leach testing of the glass. A major difference is that no Th release was observed with MCC-1 testing whereas a small amount of Th release

TABLE 4.2. Average Normalized Mass Releases of Glasses DG-WV1 Through DG-WV8 (28-day MCC-1, Deaerated DIW, $90^{\circ} \mathrm{C}$ ), $\mathrm{g} / \mathrm{m}^{2}$

\begin{tabular}{|c|c|c|c|c|c|c|c|c|}
\hline \multirow[b]{2}{*}{ Element } & \multicolumn{8}{|c|}{ Average Normal ized Mass Release } \\
\hline & DG-WN1 & $\underline{D G-W W_{2}}$ & $D G-W 3$ & DG-WN4 & $\underline{D G-W N 5}$ & $\underline{\mathrm{DG}-W V 6}$ & $\underline{D G-W N 7}$ & $\underline{D G-W N 8}$ \\
\hline Al & 7.956 & 8.071 & 8.969 & 9.931 & 7.953 & 8.011 & 7.913 & 7.497 \\
\hline B & 9.499 & 9.940 & 14.066 & 14.011 & 10.908 & 9.330 & 9.530 & 8.672 \\
\hline cs & 20.193 & 20.167 & 34.396 & 28.813 & 26.279 & 22.499 & 27.229 & 6.792 \\
\hline $\mathrm{Fe}$ & 0.043 & 0.046 & 0.095 & 0.049 & 0.080 & 0.109 & 0.063 & 0.047 \\
\hline k & 1.385 & 7.540 & 6.066 & 3.758 & 1.345 & 5.760 & 3.491 & 3.049 \\
\hline Li & 9.230 & 9.952 & 13.839 & 13.935 & 11.169 & 9.171 & 9.604 & 8.605 \\
\hline $\mathrm{Mg}$ & 5.672 & 5.367 & 1.303 & 1.417 & 4.196 & 5.507 & 5.635 & 5.209 \\
\hline $\mathrm{Mn}$ & 0.085 & 0.088 & 0.105 & 0.065 & 0.097 & 0.137 & 0.102 & 0.085 \\
\hline $\mathrm{Na}$ & 9.008 & 9.536 & 13.479 & 13.795 & 10.630 & 8.886 & 9.545 & 8.736 \\
\hline $\mathbf{P}$ & 5.623 & 5.592 & 10.122 & 9.906 & 6.129 & 4.9 & 4.564 & 5.417 \\
\hline si & 8.443 & 8.586 & 11.027 & 10.950 & 9.232 & 8.344 & 8.518 & 7.765 \\
\hline Th & 0.000 & 0.000 & 0.000 & 0.000 & 0.000 & 0.000 & 0.000 & 0.000 \\
\hline $\mathrm{Ti}$ & 0.000 & 0.000 & 0.000 & 0.000 & 0.000 & 0.000 & 0.000 & 0.000 \\
\hline U & 1.508 & 1.411 & 1.441 & 1.518 & 1.265 & 1.168 & 1.725 & 1.334 \\
\hline $\mathrm{pH}{ }^{(a)}$ & 8.95 & 8.70 & 9.10 & 9.08 & 8.82 & 8.48 & 8.58 & 8.79 \\
\hline
\end{tabular}

(a) $\mathrm{pH}$ measured at test termination at $25^{\circ} \mathrm{C}$. 


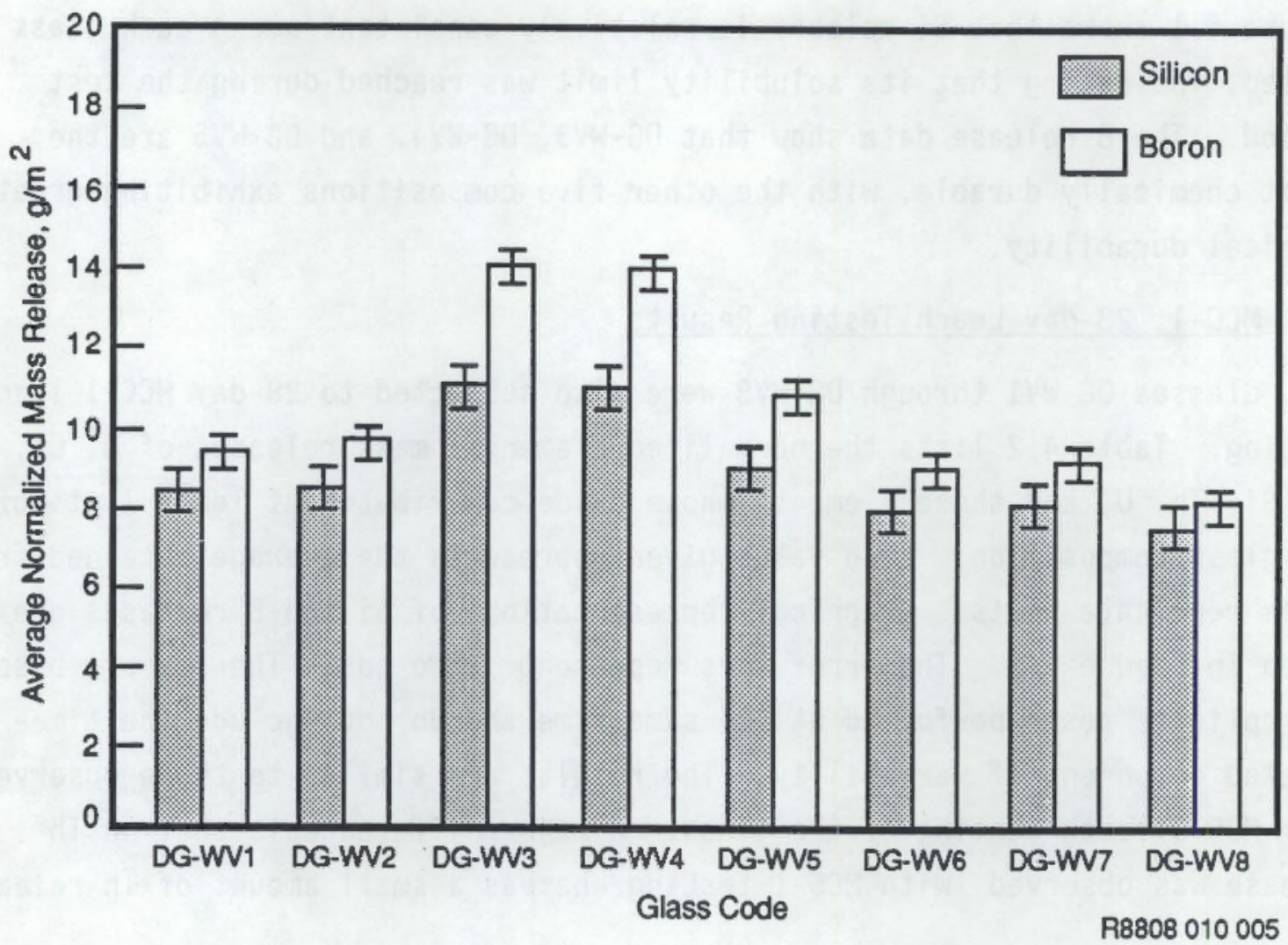

FIGURE 4.2. Comparison of Si and B Normalized Mass Releases from DG-WVI Through DG-WV8 (MCC-1 test, $90^{\circ} \mathrm{C}$, deaerated DIW, 28-day)

was observed with MCC-3 testing. Analysis of these releases shows that the chemical durability of the reference glass, DG-WV1, and reference glass containing noble metal (Rh, Ru, Pd) oxides, DG-WV2, are essentially identical, and that the variations in $\mathrm{P}_{2} \mathrm{O}_{5}, \mathrm{ThO}_{2}$ and $\mathrm{B}_{2} \mathrm{O}_{3}$ have little, if any, real effect on the product chemical durability.

\subsubsection{Second Set of FY 1987 Glasses--DG-WV15 Through DG-WV30}

\section{MCC-3, 7-day Leach Test Results}

Table 4.3 lists the normalized elemental mass releases, obtained through 7-day MCC-3 tests of $\mathrm{B}, \mathrm{Cs}, \mathrm{Na}, \mathrm{Si}, \mathrm{Th}, \mathrm{U}$, and those elements whose oxide contributed at least $1 \mathrm{wt} \%$ of the glass composition. Each value given represents the average obtained from three replicate tests. 
TABLE 4.3. Average Normalized Mass Releases of Glasses DG-WY15 Through DG-WV30 (7-day MCC-3, deaerated DIW, $90^{\circ} \mathrm{C}$ ) $-\mathrm{g} / \mathrm{m}^{2}$

\begin{tabular}{|c|c|c|c|c|c|c|c|c|}
\hline Element & DG-LN15 & DG-WN16 & DG-WN17 & DG-LN18 & DG-LN19 & DG-WN2O & DG-WN21 & DG-WN22 \\
\hline $\begin{array}{l}\mathrm{Al} \\
\mathrm{B} \\
\mathrm{Ce} \\
\mathrm{Ce}\end{array}$ & $\begin{array}{l}0.103 \\
0.264 \\
0.001 \\
0.000\end{array}$ & $\begin{array}{l}0.108 \\
0.181 \\
0.003 \\
0.000\end{array}$ & $\begin{array}{l}0.110 \\
0.273 \\
0.000 \\
0.000\end{array}$ & $\begin{array}{l}0.127 \\
0.210 \\
0.000 \\
0.000\end{array}$ & $\begin{array}{l}0.126 \\
0.207 \\
0.000 \\
0.000\end{array}$ & $\begin{array}{l}0.113 \\
0.148 \\
0.000 \\
0.000\end{array}$ & $\begin{array}{l}0.150 \\
0.205 \\
0.012 \\
0.005\end{array}$ & $\begin{array}{l}0.136 \\
0.185 \\
0.008 \\
0.004\end{array}$ \\
\hline $\begin{array}{l}\mathrm{Cs} \\
\mathrm{Fe} \\
\mathrm{K} \\
\mathrm{Li}\end{array}$ & $\begin{array}{l}0.097 \\
0.002 \\
0.103 \\
0.287\end{array}$ & $\begin{array}{l}0.089 \\
0.002 \\
0.113 \\
0.243\end{array}$ & $\begin{array}{l}0.097 \\
0.002 \\
0.106 \\
0.296\end{array}$ & $\begin{array}{l}0.061 \\
0.005 \\
0.141 \\
0.266\end{array}$ & $\begin{array}{l}0.085 \\
0.002 \\
0.102 \\
0.286\end{array}$ & $\begin{array}{l}0.112 \\
0.002 \\
0.000 \\
0.241\end{array}$ & $\begin{array}{l}0.099 \\
0.006 \\
0.202 \\
0.252\end{array}$ & $\begin{array}{l}0.091 \\
0.003 \\
0.076 \\
0.294\end{array}$ \\
\hline $\begin{array}{l}\mathrm{Mg} \\
\mathrm{Mn} \\
\mathrm{Na} \\
\mathrm{P}\end{array}$ & $\begin{array}{l}0.006 \\
0.002 \\
0.243 \\
0.215\end{array}$ & $\begin{array}{l}0.005 \\
0.002 \\
0.155 \\
0.084\end{array}$ & $\begin{array}{l}0.000 \\
0.002 \\
0.248 \\
0.237\end{array}$ & $\begin{array}{l}0.000 \\
0.004 \\
0.207 \\
0.170\end{array}$ & $\begin{array}{l}0.006 \\
0.002 \\
0.190 \\
0.170\end{array}$ & $\begin{array}{l}0.000 \\
0.001 \\
0.125 \\
0.051\end{array}$ & $\begin{array}{l}0.011 \\
0.005 \\
0.205 \\
0.131\end{array}$ & $\begin{array}{l}0.000 \\
0.003 \\
0.160 \\
0.091\end{array}$ \\
\hline $\begin{array}{l}\text { si } \\
\text { Th } \\
T i \\
U\end{array}$ & $\begin{array}{l}0.115 \\
0.000 \\
0.000 \\
0.023\end{array}$ & $\begin{array}{l}0.111 \\
0.000 \\
0.001 \\
0.022\end{array}$ & $\begin{array}{l}0.117 \\
0.000 \\
0.000 \\
0.019\end{array}$ & $\begin{array}{l}0.126 \\
0.004 \\
0.004 \\
0.042\end{array}$ & $\begin{array}{l}0.112 \\
0.001 \\
0.000 \\
0.036\end{array}$ & $\begin{array}{l}0.105 \\
0.000 \\
0.001 \\
0.006\end{array}$ & $\begin{array}{l}0.136 \\
0.010 \\
0.006 \\
0.044\end{array}$ & $\begin{array}{l}0.128 \\
0.007 \\
0.003 \\
0.036\end{array}$ \\
\hline $\mathrm{pH}^{(a)}$ & 7.88 & 8.56 & 9.26 & 9.18 & 9.03 & 8.57 & 8.86 & 8.44 \\
\hline Element & DG-WN23 & DG-WV24 & DG-WN25 & $\underline{D G-W V 26}$ & DG-WV27 & DG-WV28 & DG-WV29 & $\underline{D G-W \sqrt{3} 0}$ \\
\hline $\begin{array}{l}\mathrm{Al} \\
\mathrm{B} \\
\mathrm{Ca} \\
\mathrm{Ce}\end{array}$ & $\begin{array}{l}0.136 \\
0.232 \\
0.000 \\
0.019\end{array}$ & $\begin{array}{l}0.123 \\
0.193 \\
0.000 \\
0.000\end{array}$ & $\begin{array}{l}0.125 \\
0.179 \\
0.000 \\
0.000\end{array}$ & $\begin{array}{l}0.101 \\
0.172 \\
0.000 \\
0.000\end{array}$ & $\begin{array}{l}0.149 \\
0.250 \\
0.004 \\
0.004\end{array}$ & $\begin{array}{l}0.130 \\
0.188 \\
0.007 \\
0.006\end{array}$ & $\begin{array}{l}0.101 \\
0.207 \\
0.004 \\
0.000\end{array}$ & $\begin{array}{l}0.126 \\
0.205 \\
0.006 \\
0.000\end{array}$ \\
\hline $\begin{array}{l}\text { Cs } \\
\text { Fe } \\
\text { K } \\
\mathrm{Li}\end{array}$ & $\begin{array}{l}0.031 \\
0.020 \\
0.054 \\
0.294\end{array}$ & $\begin{array}{l}0.071 \\
0.004 \\
0.058 \\
0.284\end{array}$ & $\begin{array}{l}0.082 \\
0.005 \\
0.032 \\
0.264\end{array}$ & $\begin{array}{l}0.108 \\
0.002 \\
0.064 \\
0.265\end{array}$ & $\begin{array}{l}0.071 \\
0.008 \\
0.084 \\
0.300\end{array}$ & $\begin{array}{l}0.073 \\
0.009 \\
0.061 \\
0.301\end{array}$ & $\begin{array}{l}0.103 \\
0.005 \\
0.097 \\
0.260\end{array}$ & $\begin{array}{l}0.099 \\
0.002 \\
0.113 \\
0.281\end{array}$ \\
\hline $\begin{array}{l}\mathrm{Mg} \\
\mathrm{Mn} \\
\mathrm{Ne} \\
\mathrm{P}\end{array}$ & $\begin{array}{l}0.012 \\
0.015 \\
0.172 \\
0.078\end{array}$ & $\begin{array}{l}0.000 \\
0.003 \\
0.156 \\
0.141\end{array}$ & $\begin{array}{l}0.000 \\
0.002 \\
0.153 \\
0.085\end{array}$ & $\begin{array}{l}0.000 \\
0.002 \\
0.144 \\
0.094\end{array}$ & $\begin{array}{l}0.000 \\
0.004 \\
0.208 \\
0.105\end{array}$ & $\begin{array}{l}0.000 \\
0.008 \\
0.156 \\
0.103\end{array}$ & $\begin{array}{l}0.012 \\
0.005 \\
0.194 \\
0.201\end{array}$ & $\begin{array}{l}0.003 \\
0.001 \\
0.206 \\
0.123\end{array}$ \\
\hline $\begin{array}{l}\text { Si } \\
\text { Th } \\
T i \\
U\end{array}$ & $\begin{array}{l}0.132 \\
0.023 \\
0.021 \\
0.052\end{array}$ & $\begin{array}{l}0.117 \\
0.003 \\
0.003 \\
0.030\end{array}$ & $\begin{array}{l}0.119 \\
0.002 \\
0.002 \\
0.031\end{array}$ & $\begin{array}{l}0.098 \\
0.000 \\
0.001 \\
0.028\end{array}$ & $\begin{array}{l}0.133 \\
0.007 \\
0.007 \\
0.022\end{array}$ & $\begin{array}{l}0.128 \\
0.011 \\
0.008 \\
0.034\end{array}$ & $\begin{array}{l}0.113 \\
0.000 \\
0.001 \\
0.033\end{array}$ & $\begin{array}{l}0.122 \\
0.001 \\
0.001 \\
0.029\end{array}$ \\
\hline $\mathrm{pH}^{\text {(a) }}$ & 9.29 & 9.39 & 9.50 & 9.43 & 9.48 & 9.49 & 9.80 & 9.66 \\
\hline
\end{tabular}

(a) $\mathrm{pH}$ measured at test termination at $25^{\circ} \mathrm{C}$.

Graphical representation of $\mathrm{Si}$ and $\mathrm{B}$ releases are given in Figures 4.3 and 4.4. Based on B release, the glasses were ordered from least to most chemically durable in these figures. The error bars represent \pm two sds. The sds are based on replicate tests performed at the same time and do not 


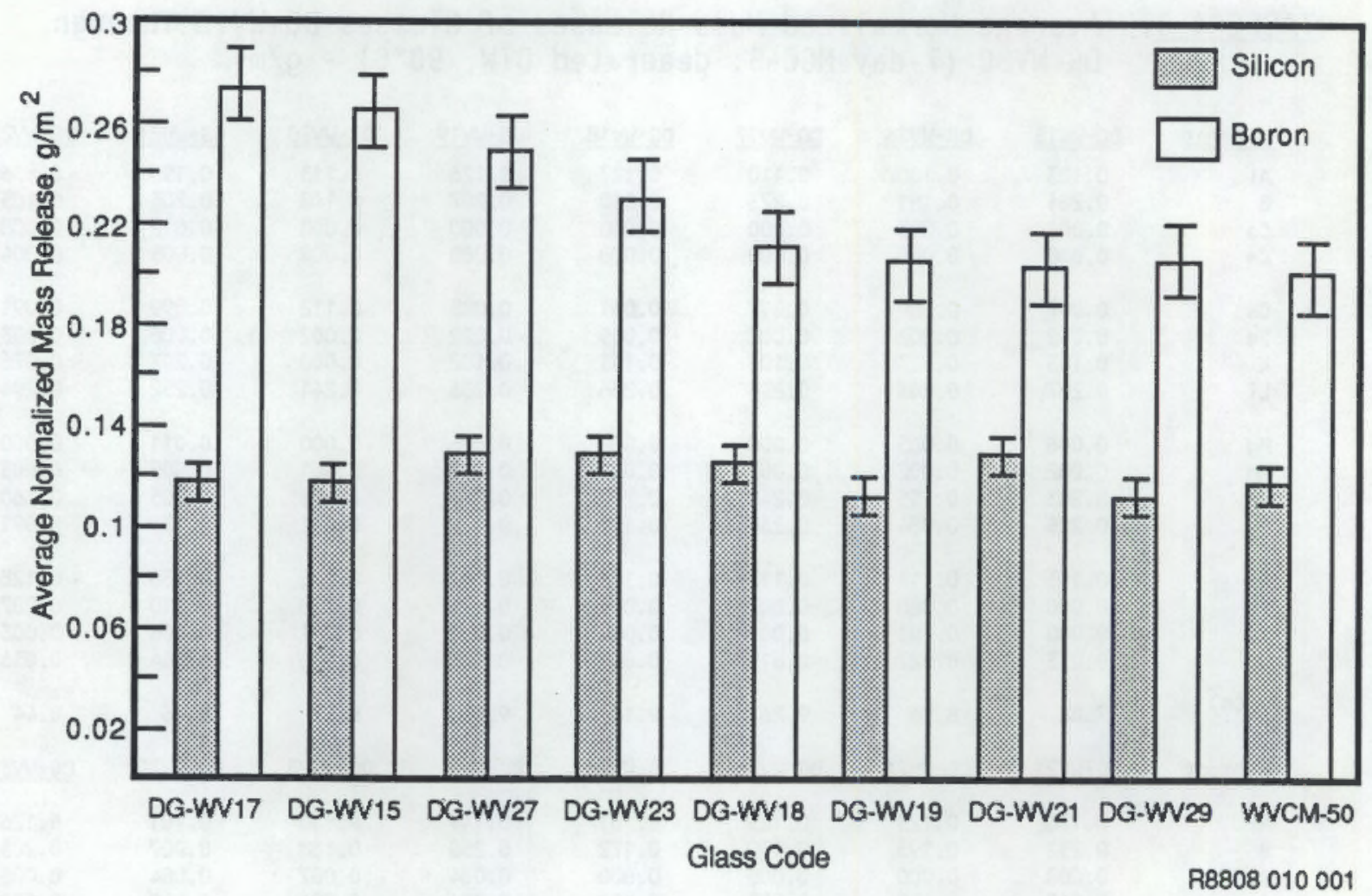

FIGURE 4.3. Comparison of Si and B Normalized Mass Releases of Least Durable of Second Set of Compositional Variability Glasses (Ordered from least to greatest durability based on boron release. Modified MCC -3 test, $90^{\circ} \mathrm{C}$, deareated DIW, 7-day.)

include the time-related component of variability. The releases of the reference glass, WVCM-50 (DG-WV30), are included in each figure for direct comparison.

Roughly half of the glasses tested had greater chemical durability than the nominal WVCM-50 composition. The compositional variation caused maximum $B$ releases of $34 \%$ higher and $29 \%$ lower than WVCM-50. The two least chemically durable glasses, DG-WV17 and DG-WV15, contain low amounts of $\left(\mathrm{Al}_{2} \mathrm{O}_{3}+\right.$ $\mathrm{SiO}_{2}$ ) and high amounts of $\mathrm{Alkaline}$ earths, $\mathrm{MnO}_{2}$, and "other" oxides relative to the nominal WVCM-50 composition. (a) This combination apparently is disrupting the $\mathrm{Si-0}-\mathrm{Si}$ glass network, making $\mathrm{H}_{2} \mathrm{O}$ attack easier and allowing

(a) See footnote on Table 3.5 for complete listing of other oxides. 


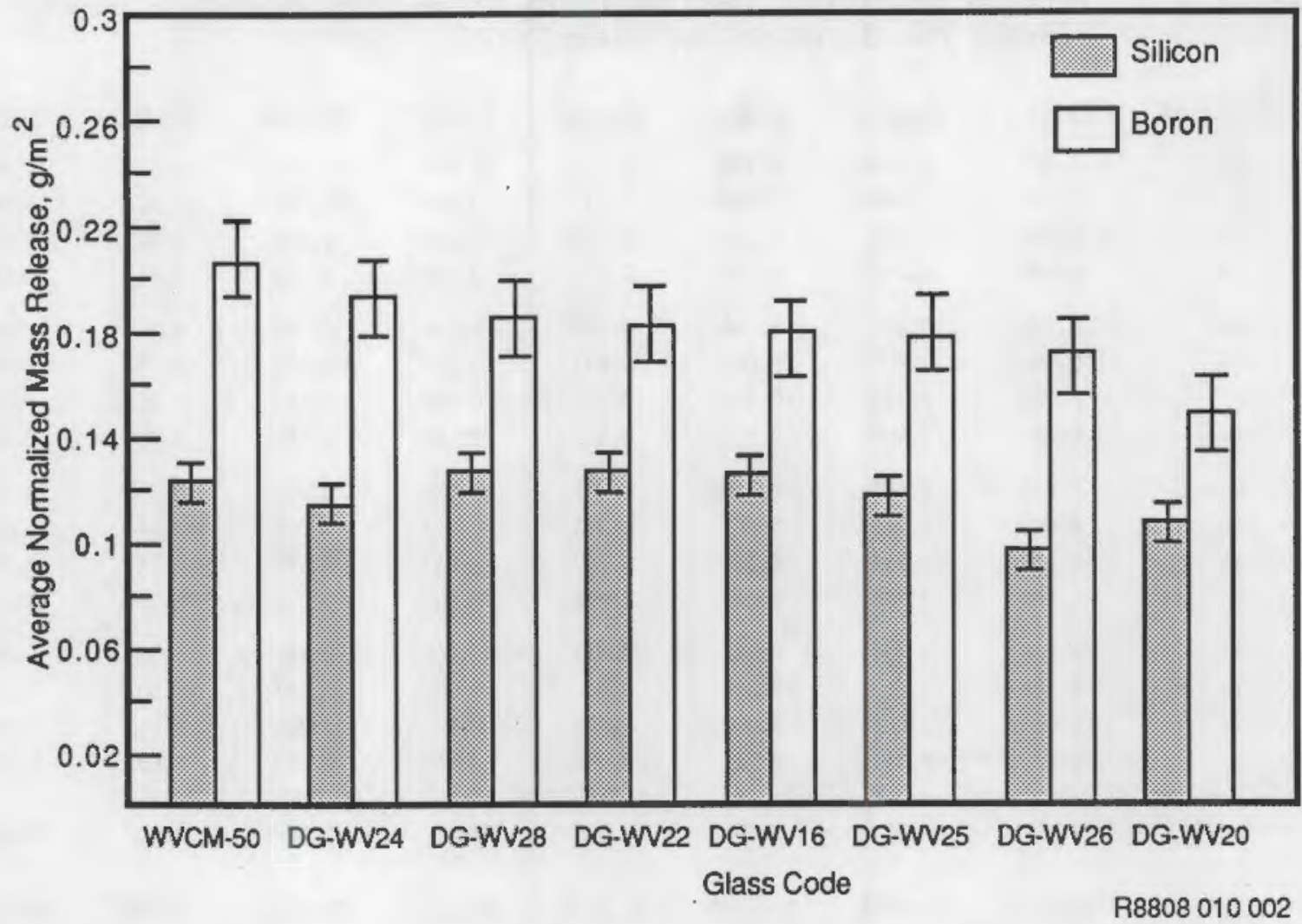

FIGURE 4.4. Comparison of Si and B Normalized Mass Releases of Most Durable of Second Set of Compositional Variability Glasses (Ordered from least to greatest durability based on boron release. Modified MCC -3 test, $90^{\circ} \mathrm{C}$, deareated DIW, 7-day.)

the solution $\mathrm{pH}$ to increase with increased glass dissolution. The most chemically durable glass, DG-WV2O, contains high amounts of $\left(\mathrm{Al}_{2} \mathrm{O}_{3}+\mathrm{SiO}_{2}\right)$ and was observed to have the highest T100P (temperature at which the viscosity of the glass is 100 poise). The structure of this glass is more chemically resistant to $\mathrm{H}_{2} \mathrm{O}$ attack, possibly due to having more bridging oxygens within its random structure.

\section{MCC-3, 28-Day Leach Test Results}

Table 4.4 lists the normalized elemental mass releases of B, Cs, Na, Si, Th, $U$, and those elements whose oxide contributed at least $1 \mathrm{wt} \%$ of the glass composition. Each value given represents the average obtained from three replicate tests. 
TABLE 4.4. Average Normalized Mass Releases of Glasses DG-WV15 - DG-WV30 (28-day MCC-3, Deaerated Water, $90^{\circ} \mathrm{C}$ ), $\mathrm{g} / \mathrm{m}^{2}$

\begin{tabular}{|c|c|c|c|c|c|c|c|c|}
\hline Element & DG-WN15 & DG-LN16 & DG-WN17 & DG-WV18 & DG-WN19 & DG-WV2O & DG-WV21 & $\underline{D G-W N 22}$ \\
\hline Al & 0.121 & 0.126 & 0.118 & 0.151 & 0.155 & 0.141 & 0.176 & 0.161 \\
\hline B & 0.412 & 0.268 & 0.350 & 0.291 & 0.309 & 0.199 & 0.270 & 0.267 \\
\hline $\mathrm{Ca}$ & 0.003 & 0.004 & 0.003 & 0.009 & 0.005 & 0.004 & 0.011 & 0.013 \\
\hline $\mathrm{Ce}$ & 0.000 & 0.000 & 0.000 & 0.000 & 0.000 & 0.002 & 0.007 & 0.011 \\
\hline Cs & 0.114 & 0.054 & 0.146 & 0.105 & 0.144 & 0.100 & 0.111 & 0.073 \\
\hline $\mathrm{Fe}$ & 0.009 & 0.008 & 0.007 & 0.013 & 0.011 & 0.008 & 0.014 & 0.007 \\
\hline K & 0.122 & 0.138 & 0.180 & 0.110 & 0.136 & 0.122 & 0.096 & 0.101 \\
\hline Li & 0.436 & 0.401 & 0.381 & 0.385 & 0.422 & 0.381 & 0.360 & 0.443 \\
\hline $\mathrm{Mg}$ & 0.018 & 0.025 & 0.010 & 0.038 & 0.035 & 0.015 & 0.017 & 0.000 \\
\hline Mn & 0.009 & 0.011 & 0.007 & 0.015 & 0.012 & 0.005 & 0.016 & 0.011 \\
\hline $\mathrm{Na}$ & 0.302 & 0.211 & 0.330 & 0.260 & 0.261 & 0.152 & 0.247 & 0.194 \\
\hline P & 0.261 & 0.148 & 0.238 & 0.216 & 0.253 & 0.059 & 0.161 & 0.087 \\
\hline si & 0.144 & 0.138 & 0.137 & 0.151 & 0.147 & 0.135 & 0.161 & 0.157 \\
\hline Th & 0.001 & 0.002 & 0.000 & 0.004 & 0.002 & 0.001 & 0.003 & 0.003 \\
\hline$T i$ & 0.002 & 0.003 & 0.002 & 0.006 & 0.002 & 0.005 & 0.013 & 0.007 \\
\hline U & 0.029 & 0.035 & 0.021 & 0.050 & 0.065 & 0.013 & 0.053 & 0.048 \\
\hline $\mathrm{PH}^{(\mathrm{a})}$ & 9.45 & 8.88 & 9.69 & 9.66 & 9.47 & 9.40 & 9.03 & 8.86 \\
\hline Element & DG-WN23 & DG-WV24 & DG-WN25 & DG-WN26 & DG-WR27 & DG-WV28 & DG-WN29 & DG-WN30 \\
\hline Al & 0.173 & 0.144 & 0.137 & 0.122 & 0.168 & 0.156 & 0.124 & 0.139 \\
\hline B & 0.423 & 0.282 & 0.213 & 0.255 & 0.449 & 0.229 & 0.297 & 0.271 \\
\hline $\mathrm{Ca}$ & 0.017 & 0.002 & 0.002 & 0.002 & 0.001 & 0.008 & 0.006 & 0.003 \\
\hline $\mathrm{Ce}$ & 0.036 & 0.000 & 0.000 & 0.000 & 0.010 & 0.013 & 0.000 & 0.000 \\
\hline Cs & 0.062 & 0.113 & 0.150 & 0.116 & 0.085 & 0.122 & 0.110 & 0.127 \\
\hline Fe & 0.038 & 0.010 & 0.011 & 0.008 & 0.014 & 0.015 & 0.015 & 0.008 \\
\hline K & 0.071 & 0.134 & 0.245 & 0.105 & 0.088 & 0.118 & 0.156 & 0.166 \\
\hline Li & 0.614 & 0.405 & 0.353 & 0.372 & 0.473 & 0.406 & 0.357 & 0.380 \\
\hline Mg & 0.019 & 0.026 & 0.008 & 0.022 & 0.000 & 0.017 & 0.033 & 0.022 \\
\hline Mn & 0.027 & 0.014 & 0.008 & 0.008 & 0.008 & 0.017 & 0.015 & 0.008 \\
\hline $\mathrm{Na}$ & 0.227 & 0.202 & 0.173 & 0.188 & 0.284 & 0.170 & 0.270 & 0.226 \\
\hline $\mathbf{P}$ & 0.051 & 0.079 & 0.038 & 0.054 & 0.059 & 0.050 & 0.212 & 0.081 \\
\hline si & 0.167 & 0.140 & 0.138 & 0.129 & 0.151 & 0.151 & 0.143 & 0.140 \\
\hline Th & 0.029 & 0.003 & 0.004 & 0.001 & 0.008 & 0.009 & 0.004 & 0.002 \\
\hline Ti & 0.035 & 0.006 & 0.007 & 0.003 & 0.012 & 0.013 & 0.008 & 0.003 \\
\hline$U$ & 0.066 & 0.046 & 0.031 & 0.034 & 0.034 & 0.032 & 0.061 & 0.034 \\
\hline $\mathrm{pH}^{(\mathrm{a})}$ & 8.82 & 8.88 & 9.07 & 8.82 & 9.06 & 9.07 & 9.38 & 9.24 \\
\hline
\end{tabular}

(a) $\mathrm{pH}$ measured at test termination at $25^{\circ} \mathrm{C}$. 
Graphical representation of $\mathrm{B}$ and $\mathrm{Si}$ are given in Figures 4.5 and 4.6. Based on $B$ release, the glasses were ordered from least to most chemically durable in these figures. The error bars represent \pm two sds. The sds are based on replicate tests performed at the same time and do not include the time-related component of variability. Error bars are not given for Si due to their small range. The releases of the reference glass, WVCM-50 (DG-WV30) are included in each figure for direct comparison.

The results of the 28-day testing correspond with what was observed with 7-day testing. The normalized releases are higher than in the 7-day testing (from 10 to $300 \%$ ) as are the test termination leachant $\mathrm{pH}$ values $(0.3$ to $0.5 \mathrm{pH}$ units); however, the relative order of durabilities of the glasses, based on $B$ release, corresponds to the 7 -day test results. Roughly half of

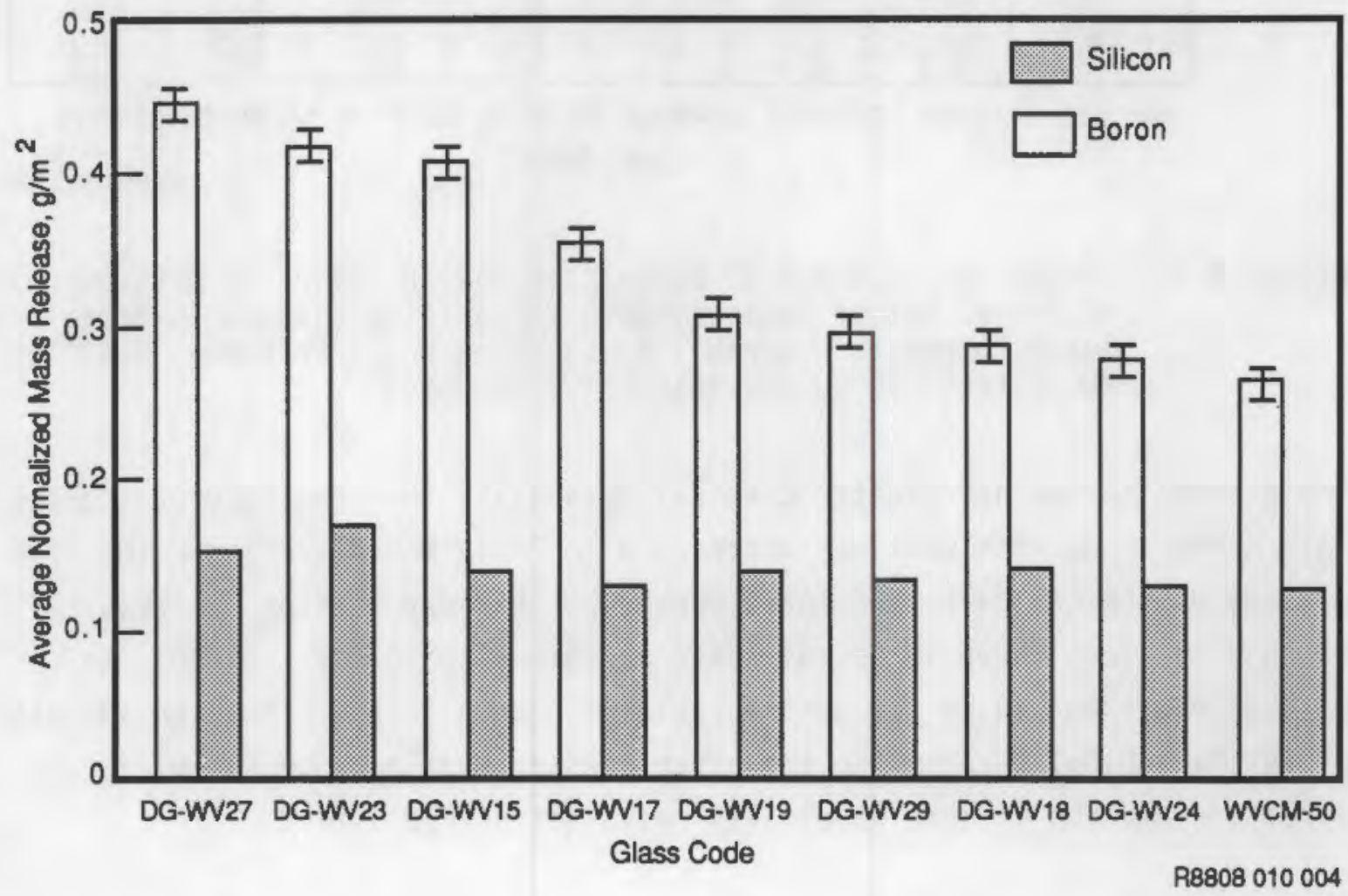

FIGURE 4.5. Comparison of B and Si Normalized Mass Releases of Least Durable of Second Set of Compositional Variability Glasses (Ordered from least to greatest durability based on boron release. Modified MCC -3 test, $90^{\circ} \mathrm{C}$, deareated DIW, 28-day.) 


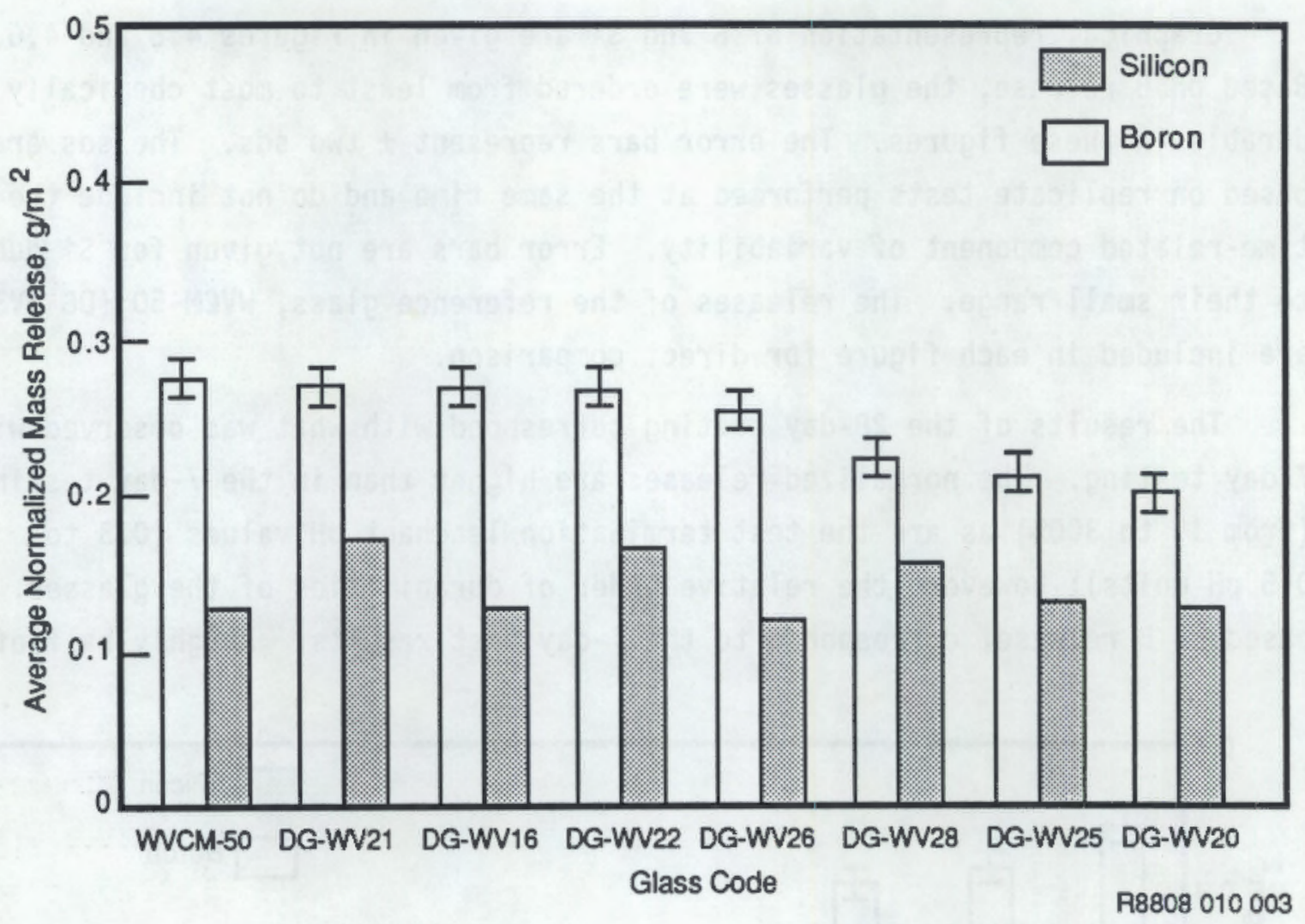

FIGURE 4.6. Comparison of B and Si Normalized Mass Releases of Most Durable of Second Set of Compositional Variability Glasses (Ordered from least to greatest durability based on boron release. Modified MCC -3 test, $90^{\circ} \mathrm{C}$, deareated DIW, 28-day.)

the glasses tested had greater chemical durability than the reference glass. This corresponds with what was observed with 7-day MCC-3 testing. The four glasses determined to be the least durable with 7-day testing, DG-WV15, 17, 23 , and 27 , were shown to be the least durable with 28-day testing also. DG-WV20 was shown to be the most durable with both tests. The high amounts of $\left(\mathrm{Al}_{2} \mathrm{O}_{3}+\mathrm{SiO}_{2}\right)$ relative to the other glasses must enhance the glass structure, making it more chemically resistant to $\mathrm{H}_{2} \mathrm{O}$ attack. 


\subsection{EMPIRICAL MODELING AND STATISTICAL ANALYSIS OF FY 1987 NORMALIZED BORON RELEASE DATA}

\subsubsection{Empirical Models for Normalized Boron Release}

To determine whether or not varying composition within the composition region studied (defined in Table 3.4) has a statistically significant effect on normalized release, i.e., chemical durability, empirical mixture models were fit to the normalized $B$ release data obtained from the 7-day MCC -3 tests. These mixture models account for the fact that the component weight fractions sum to unity. A linear mixture model of the form

$$
\text { Normalized Boron Release (NBR) }=\sum_{i=1}^{11} b_{i} x_{i}
$$

was $f i t$, where $x_{1}, \ldots, x_{11}$ are the weight fractions of the 11 oxide components listed under Single Component Constraints in Table 4 and $b_{1}, \ldots, b_{11}$ are the model parameters estimated via least squares regression. Models of this form are useful in assessing the importance of the components, provided the linear blending effects of the components are large relative to the nonlinear blending effects. Models of this form can indicate whether or not varying composition affects chemical durability, even if they have a moderate lack of fit.

Models were fit to the total 24 compositional variability glasses and al so to the second set of 16 . Least squares regression was used to estimate the parameters of the model. The fitted models for the 16- and 24-glass data sets are given respectively in Equation (4) and Equation (5):

$$
\begin{aligned}
\text { NBR }= & -1.4572 \mathrm{Al}_{2} \mathrm{O}_{3}+1.0393 \mathrm{~B}_{2} \mathrm{O}_{3}-0.3764(\mathrm{BaO}+\mathrm{CaO}+\mathrm{MgO})+ \\
& 0.4039 \mathrm{Fe}_{2} \mathrm{O}_{3}+2.3528\left(\mathrm{~K}_{2} \mathrm{O}+\mathrm{Li}_{2} \mathrm{O}+\mathrm{Na}_{2} \mathrm{O}\right)+0.9566 \mathrm{MnO}_{2}+ \\
& 0.1607 \mathrm{P}_{2} \mathrm{O}_{5}-0.4841 \mathrm{SiO}_{2}+0.9420 \mathrm{ThO}_{2}+1.8447 \mathrm{UO}_{2}+ \\
& 0.7892 \text { Others }
\end{aligned}
$$


and

$$
\begin{aligned}
\mathrm{NBR}= & -1.3200 \mathrm{Al}_{2} \mathrm{O}_{3}+0.6571 \mathrm{~B}_{2} \mathrm{O}_{3}-0.2333(\mathrm{BaO}+\mathrm{CaO}+\mathrm{MgO})+ \\
& 0.3999 \mathrm{Fe}_{2} \mathrm{O}_{3}+2.0574\left(\mathrm{~K}_{2} \mathrm{O}+\mathrm{Li}_{2} \mathrm{O}+\mathrm{Na}_{2} \mathrm{O}\right)+1.0203 \mathrm{MnO}_{2}+ \\
& 0.2260 \mathrm{P}_{2} \mathrm{O}_{5}-0.3245 \mathrm{SiO}_{2}+0.9641 \mathrm{ThO}_{2}+1.7413 \mathrm{UO}_{2}+ \\
& 0.8085 \text { others }
\end{aligned}
$$

where NBR is normalized boron release from the 7 -day MCC-3 leach test, $\mathrm{g} / \mathrm{m}^{2}$. These two models fit their respective data sets well, with respective $\mathrm{R}^{2}$ values (proportion of total variation in NBR explained) of 0.94 and 0.90 . The models do not have a statistically significant lack of fit. Varying composition within the defined composition region (Table 3.4 ) does appear to have a statistically significant effect on chemical durability.

Linear mixture models similar to (4.2) and (4.3) were also fit to normalized Si release, but are not presented here. However, the model fit to the Si release data from all 24 FY 1987 glasses was applied to produce an effects plot to be discussed shortly.

Equation (4.2) was used to predict NBR for the eight glasses of the first set. The results were used to check the usefulness of the models as predictive tools, i.e., to validate the models. Table 4.5 lists the measured and predicted values for each glass. The individual and simultaneous $95 \%$ prediction intervals for each glass are also given in Table 4.5. The individual prediction intervals provide $95 \%$ confidence that the interval will contain a single observed value of NBR for the corresponding glass. The eight simultaneous prediction intervals (Miller 1981) provide $95 \%$ confidence that all eight intervals will contain individual measured NBR values.

As shown by Table 4.5, the predicted NBR values compare well with the observed values, and the observed values all fall within both the individual and simultaneous prediction intervals. This is very good evidence that the models can be reasonably used for prediction purposes within the composition region studied.

Effects plots (Piepel 1982) that demonstrate the effects of varying individual oxide components are presented in Figures 4.7 and 4.8 for $\mathrm{B}$ and $\mathrm{Si}$ releases. In a given effects plot, there is one effect curve for each 
TABLE 4.5. Comparison of Observed Normalized Boron Release Values to Predicted Values and Prediction Intervals (7-day MCC-3), $\mathrm{g} / \mathrm{m}^{2}$

\begin{tabular}{|c|c|c|c|c|c|c|}
\hline \multirow[b]{3}{*}{ lass } & \multirow{3}{*}{$\begin{array}{l}\text { Observed yalues } \\
\left(\mathrm{g} / \mathrm{m}^{2}\right)\end{array}$} & \multirow[b]{3}{*}{$\begin{array}{c}\text { Predicted } \\
\text { Value } \\
\end{array}$} & \multirow{2}{*}{\multicolumn{4}{|c|}{ Individual Simultaneous }} \\
\hline & & & & & & \\
\hline & & & $\begin{array}{l}\text { Lower } \\
\text { Limit }\end{array}$ & $\begin{array}{l}\text { Up } \\
\text { Li }\end{array}$ & $\begin{array}{l}\text { Lower } \\
\text { Limit }\end{array}$ & \\
\hline -WV1 & $1842,0.1855,0.1$ & 1875 & 0.1194 & 0.2557 & 0.0399 & 0.3352 \\
\hline i-WV2 & $892,0.1918$ & 1793 & .1133 & 0.2453 & 0.0363 & 0.3224 \\
\hline i-WV3 & 0.2364 , & 0.2210 & 0.1362 & 0.3059 & 0.0372 & 0.4048 \\
\hline -WV4 & $240^{\circ}$ & 0 & 1642 & 0.3546 & 0.0531 & 0.465 \\
\hline$-W$ & & & 12 & & & 0.700 \\
\hline -WV6 & $?$ & 0.1765 & 107 & 3 & 40 & .3191 \\
\hline -WV7 & $0.1895,0$ & 0 & 0.1168 & 0.2530 & 0.0373 & 0.3326 \\
\hline -WV8 & $.1869,0.1847,0.1865$ & 0.1480 & 0.0871 & 0.2089 & 0.0160 & 0.280 \\
\hline
\end{tabular}

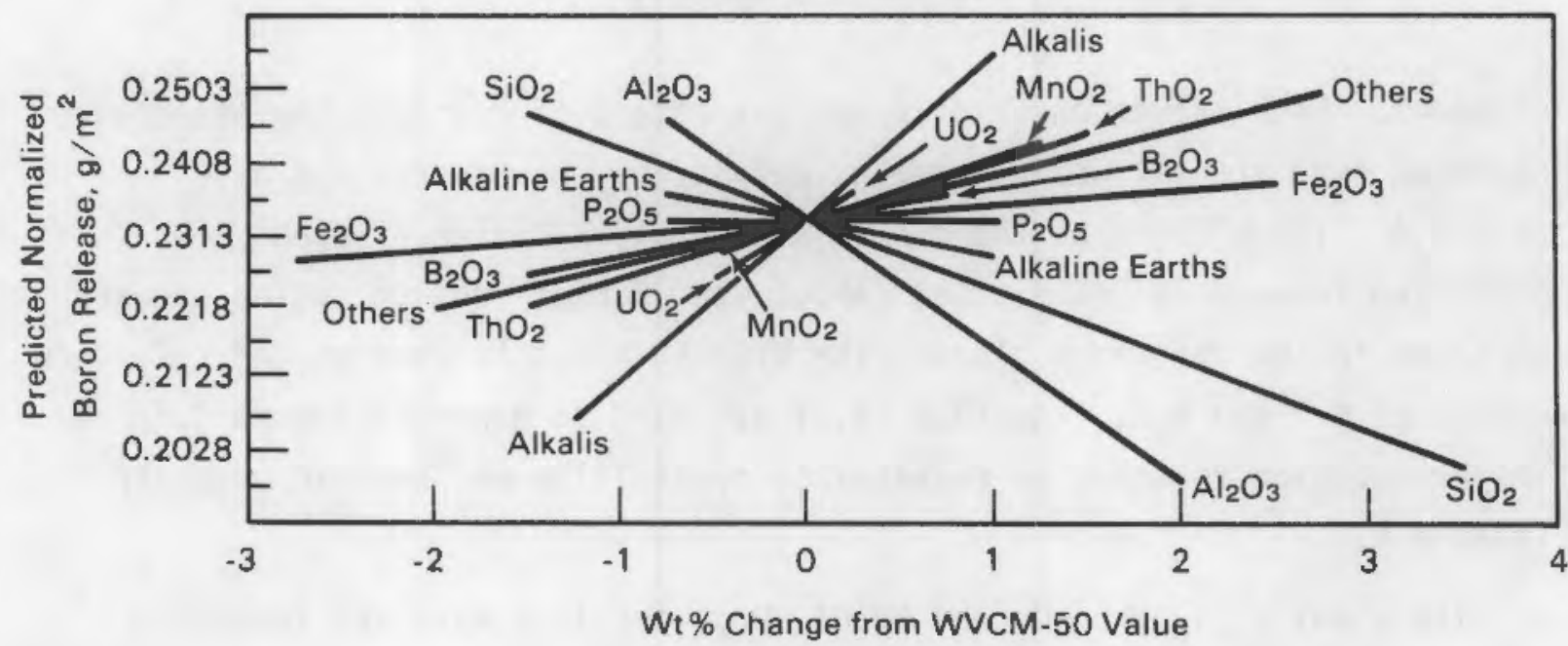

FIGURE 4.7. Component Effects Plot for Normalized Boron Release from Glasses in the WVCM-50-Based Compositional Region Tested with the 7-day Modified MCC-3 Test. (Deaerated DIW, $90^{\circ} \mathrm{C}, 24-\mathrm{gl}$ ass 1 inear mixture model.) 


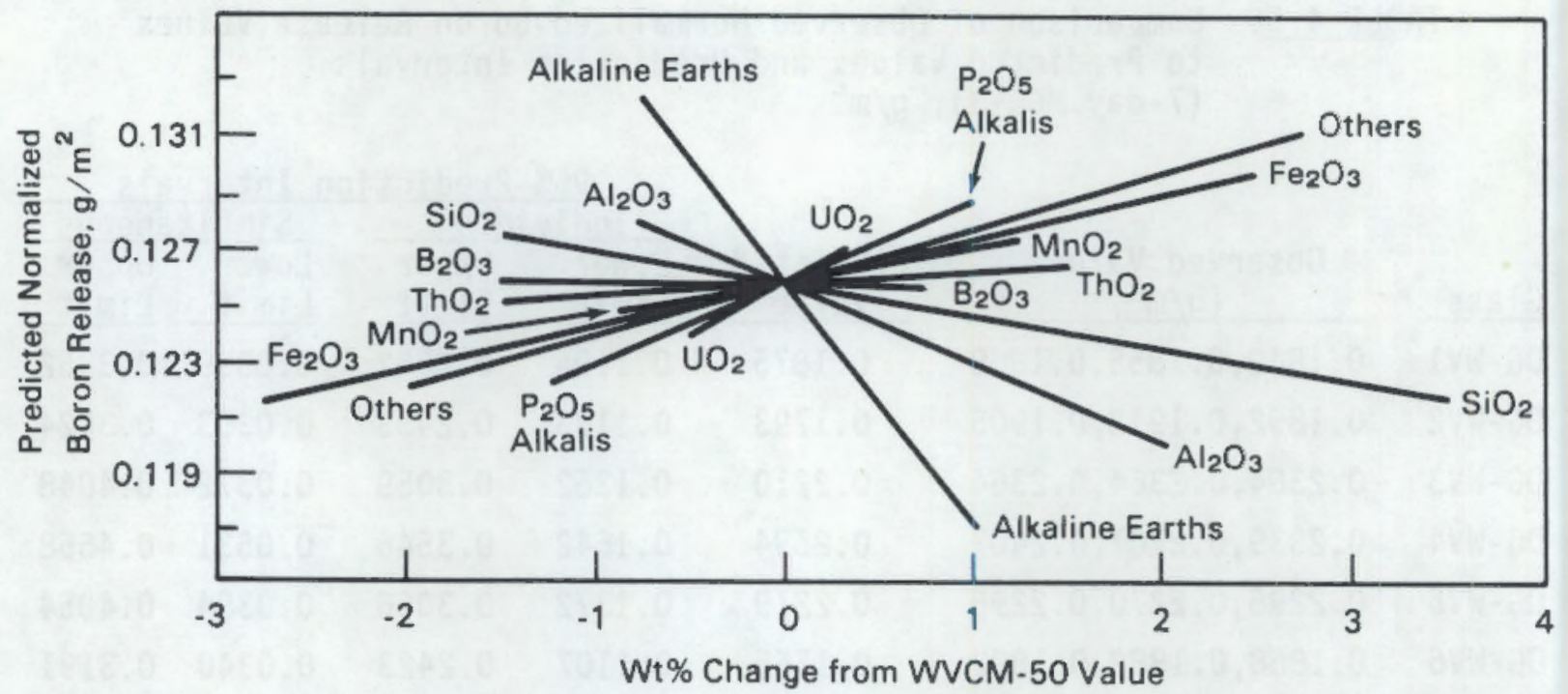

FIGURE 4.8. Component Effects Plot for Normalized Silicon Release from Glasses in the WVCM-50-Based Compositional Region Tested with the 7-day Modified MCC-3 Test. (Deaerated DIW, $90^{\circ} \mathrm{C}$, 24-glass linear-mixture model.)

component. Each effect curve displays the effect of changing the associated component over its allowable range as defined by the constraints of Table 3.4. The effects of the curves are merely a series of predicted normalized release values plotted versus wt\% changes from the value of each component in the reference glass. The WVCM- $50 \mathrm{glass}$ is used as the reference in Figures 4.7 and 4.8. Equation (4.3) was used to generate Figure 4.7. A similar equation relating $S i$ releases to composition was used to generate Figure 4.8.

The alkalis $\left(\mathrm{K}_{2} \mathrm{O}, \mathrm{Li}_{2} \mathrm{O}\right.$, and $\left.\mathrm{Na}_{2} \mathrm{O}\right), \mathrm{UO}_{2}$, and $\mathrm{ThO}_{2}$ have the largest positive effects on $\mathrm{B}$ release per-unit wt\% change. Increasing their levels tends to decrease the glass chemical durability. Conversely, the oxides $\mathrm{Al}_{2} \mathrm{O}_{3}$ and $\mathrm{SiO}_{2}$ have the largest per-unit negative effects on $\mathrm{B}$ release. From a practical standpoint, it may only be the total effects of the components that are of interest. Although the per-unit effect of $\mathrm{UO}_{2}$ is relatively large, its total effect is not as 1 arge as those of $\mathrm{MnO}_{2}$, $\mathrm{ThO}_{2}$, and "other" oxides which have 1 arger ranges. Components such as $\mathrm{P}_{2} \mathrm{O}_{5}, \mathrm{Fe}_{2} \mathrm{O}_{3}, \mathrm{~B}_{2} \mathrm{O}_{3}$, and 
the alkaline earths ( $\mathrm{BaO}, \mathrm{CaO}$, and $\mathrm{MgO})$ that have nearly horizontal effects curves in Figure 4.7 do not appear to have much effect on B release within the region studied.

\subsubsection{Boron Release Data Uncertainty}

The statistical analysis of elemental release data requires an estimation of the uncertainties in the experimentally obtained release values. To estimate these uncertainties, DG-WV1 glass was leached in triplicate four separate times over a 6-month period, which provides for estimating both short- and long-term within-laboratory uncertainties in elemental release results. The normalized releases of DG-WV1 glass and estimates of the test normalized release standard deviations are given in Appendix $A$. Both the size of the estimate of uncertainty and how well it is known are important factors in the statistical tests and confidence and tolerance bands results to be discussed shortly.

The estimate of normalized boron release uncertainty is $0.018 \mathrm{~g} / \mathrm{m}^{2}$ for the DG-WV1 glass, which translates into a $10.8 \%$ relative standard deviation (RSD). The estimate includes short- and long-term variations from 7-day MCC3 sample preparation and leach test procedures, as well as uncertainties from ICP analyses of the leachates. Because all tests were performed by PNL and al1 leachates were analyzed by the same laboratory, the estimate of uncertainty does not include lab-to-lab variation. However, the 6-month time frame over which the four sets of tests were performed may partially simulate the variation from different labs.

An important point to recognize about the above estimate of $B$ release uncertainty is that it is based on a small number of "degrees of freedom" (df), i.e., a small amount of data. Specifically, the estimate has $3 \mathrm{df}$, because the leach tests on DG-WV1 were repeated only four times. Because of the small df, it is not possible to have great confidence in the estimate, which is reflected in the statistical procedures. For example, the confidence and tolerance bands to be discussed below will be wider because of the small number of df. This "problem" can be resolved by carefully devoting a portion of future experimental efforts to properly executed replicate tests (and leachate analyses) so as to obtain an estimate of uncertainty with 
higher df. Specific comments related to the consequences of small df for the estimate of uncertainty are given in the following sections as appropriate.

\subsubsection{Confidence and Tolerance Bands}

The $95 \%$ confidence bands and $95 \% / 95 \%$ tolerance bands on the fitted mixture model are used as a means of characterizing the NBR and corresponding uncertainty over the region of interest. The formulas for these two types of bands are given in Appendix B. Explanations of their interpretations are given below.

95\% Confidence Bands: Provide 95\% confidence that every glass in the region has average NBR within the confidence bands.

95\%/95\% Tolerance Bands: Provide at least $95 \%$ confidence that $95 \%$ of the time every glass in the region will have NBR within the tolerance bands.

Confidence bands make a statement about average NBR behavior for each glass, while tolerance bands make a statement about the range of NBR behavior for each glass.

\subsubsection{Application of Confidence and Tolerance Bands}

Because the 95\% confidence bands and 95\%/95\% tolerance bands for the model are 12-dimensional surfaces (for each lower and upper band), they cannot be easily displayed. However, the bands can be applied to identify the worst predicted NBR within the region of interest. The linearity of the model implies that the largest predicted value of NBR must occur at one of the extreme vertices of the region. The results of applying the model and the upper limit formulas of the corresponding 95\% confidence and $95 \% / 95 \%$ tolerance bands allow the following statements to be made. NBR values from the 7-day MCC -3 test have been divided by 7 in these statements to yield perday release values.

- The largest predicted NBR over the region is $0.044 \mathrm{~g} / \mathrm{m}^{2} \cdot$ day. Many of the extreme vertices have predicted values that approach this level. 
- There is a $97.5 \%$ confidence that every glass in the region has an average NBR less than $0.071 \mathrm{~g} / \mathrm{m}^{2}$.day.

- There is at least a $97.5 \%$ confidence that $97.5 \%$ of the time every glass in the region will have NBR less than $0.114 \mathrm{~g} / \mathrm{m}^{2} \cdot$ day.

The last two statements are one-sided (i.e., they only refer to the worst NBR) $97.5 \%$ confidence statements derived from the two-sided $95 \%$ confidence and $95 \% / 95 \%$ tolerance bands, respectively. One-sided $95 \%$ confidence statements could be produced if desired, and would reduce the size of the 0.071 and 0.114 values in the last two statements.

\subsection{COMPOSITION EFFECTS - FY 1988}

Tables $4.6,4.7$, and 4.8 list the normalized elemental mass releases of $\mathrm{B}, \mathrm{Si}, \mathrm{Th}, \mathrm{U}$, and those elements whose oxides contributed at least $1 \mathrm{wt} \%$ of the glass composition. Each value given represents the average obtained from two replicate tests. The two replicate tests were performed at the same time under the same conditions and the resulting leachates were chemically analyzed at the same time under the same conditions. Hence, the replicates only include short-term variations in the leach testing and leachate analysis processes. Table 4.6 lists the 28 -day MCC -1 normalized elemental mass releases. Tables 4.7 and 4.8 list the 7 -day (Table 4.7 ) and 28 -day (Table 4.8) MCC-3 normalized elemental mass releases.

Graphical representations of the 28-day MCC-1 normalized elemental release rates of $\mathrm{B}$ and $\mathrm{Si}$ from the glasses are given in Figures 4.9 and 4.10. The release rates were obtained by dividing the normalized releases by 28 days; the length of the test. The error bars represent \pm two sds. The sds are based on replicate tests performed at the same time and do not include the time-related component of variability. The glasses are ordered from most to least durable. The reference glass (DG-WV33) durability is roughly in the middle of this ordering. These figures illustrate that all of the glasses tested have observed normalized release rates below the Tuff repository's requirement of $1 \mathrm{~g} / \mathrm{m}^{2} \cdot$ day in a 28 -day $M C C-1$ test. 
TABLE 4.6. Average Normalized Releases of Glasses DG-WV33 Through DG-WV48 (28-day MCC-1, $90^{\circ} \mathrm{C}$, Deaerated DIW), $\mathrm{g} / \mathrm{m}^{2}$

\begin{tabular}{|c|c|c|c|c|c|c|c|c|}
\hline Element & DGIN33 & DGUN34 & DGWV35 & DGIN36 & DGWV37 & DGWM38 & DGIN39 & DGN 40 \\
\hline Al & 9.672 & 13.369 & 12.279 & 6.909 & 11.036 & 7.443 & 8.026 & 7.211 \\
\hline B & 15.201 & 18.947 & 18.661 & 12.008 & 13.920 & 10.901 & 13.489 & 14.352 \\
\hline $\mathrm{Fe}$ & 0.041 & 0.067 & 0.092 & 0.034 & 0.053 & 0.043 & 0.097 & 0.063 \\
\hline K & 9.701 & 11.461 & 11.063 & 6.040 & 9.323 & 5.513 & 6.506 & 7.811 \\
\hline Li & 13.170 & 18.499 & 15.123 & 9.331 & 13.010 & 8.265 & 10.564 & 11.194 \\
\hline Mg & 0.000 & 0.000 & 0.000 & 0.000 & 0.000 & 0.000 & 0.627 & 0.448 \\
\hline Mn & 0.000 & 0.000 & 0.131 & 0.000 & 0.000 & 0.020 & 0.000 & 0.000 \\
\hline $\mathrm{Na}$ & 16.883 & 21.194 & 23.207 & 12.491 & 15.131 & 11.462 & 14.941 & 16.027 \\
\hline P & 12.630 & 17.901 & 11.269 & 7.513 & 11.233 & 5.635 & 10.442 & 9.240 \\
\hline si & 12.703 & 16.515 & 15.707 & 11.285 & 12.721 & 10.340 & 11.672 & 11.938 \\
\hline Th & 0.000 & 0.000 & 0.000 & 0.000 & 0.000 & 0.000 & 0.000 & 0.000 \\
\hline u & 1.869 & 0.732 & 3.308 & 0.960 & 0.980 & 0.882 & 1.475 & 1.983 \\
\hline $\mathrm{pH}^{(\mathrm{a})}$ & 9.48 & 9.55 & 9.89 & 9.16 & 9.66 & 9.30 & 9.25 & 9.62 \\
\hline Element & DGWV41 & DGUV42 & DGN43 & DGWN44 & DGN45 & DGLN46 & DG:N47 & DGWV48 \\
\hline A! & 9.585 & 9.116 & 6.056 & 11.955 & 12.028 & 8.215 & 5.458 & 5.551 \\
\hline$B_{3+}$ & 14.832 & 15.683 & 7.794 & 17.097 & 16.598 & 15.318 & 8.576 & 7.765 \\
\hline $\mathrm{Fe}^{3+}$ & 0.101 & 0.031 & 0.045 & 0.057 & 0.110 & 0.078 & 0.044 & 0.036 \\
\hline K & 8.604 & 10.666 & 4.395 & 11.728 & 10.311 & 7.697 & 3.285 & 2.790 \\
\hline Li & 13.329 & 16.669 & 6.428 & 14.068 & 12.904 & 12.661 & 5.804 & 5.699 \\
\hline $\mathrm{Mg}$ & 0.000 & 0.000 & 0.000 & 0.000 & 0.000 & 0.000 & 0.000 & 4.097 \\
\hline Mn & 0.000 & 0.052 & 0.063 & 0.000 & 0.066 & 0.097 & 0.059 & 0.000 \\
\hline $\mathrm{Na}$ & 17.809 & 16.968 & 7.845 & 20.626 & 19.470 & 16.850 & 9.018 & 7.944 \\
\hline $\mathbf{P}$ & 14.070 & 12.124 & 4.175 & 11.087 & 16.408 & 11.087 & 6.723 & 3.853 \\
\hline Si & 14.110 & 12.338 & 7.835 & 15.635 & 15.402 & 13.117 & 8.730 & 8.119 \\
\hline Th & 0.000 & 0.000 & 0.000 & 0.000 & 0.000 & 0.000 & 0.000 & 0.000 \\
\hline u & 2.564 & 0.615 & 0.745 & 3.031 & 3.347 & 2.579 & 1.135 & 0.152 \\
\hline $\mathrm{pH}^{(\mathrm{a})}$ & 9.66 & 9.59 & 8.69 & 9.61 & 9.53 & 9.43 & 8.80 & 8.59 \\
\hline
\end{tabular}

(a) $\mathrm{pH}$ measured at test termination at $25^{\circ} \mathrm{C}$. 
TABLE 4.7. Average Normalized Releases of Glasses DG-WV33 Through DG-WV48 (7-day MCC $-3,90^{\circ} \mathrm{C}$, Deaerated DIW), $\mathrm{g} / \mathrm{m}^{2}$

\begin{tabular}{|c|c|c|c|c|c|c|c|c|}
\hline Element & DGWN33 & DGWN34 & DGM $\sqrt{35}$ & DGN 36 & DGin37 & DGN $\sqrt{38}$ & DGN 39 & DGWN40 \\
\hline Al & 0.108 & 0.113 & 0.175 & 0.101 & 0.147 & 0.130 & 0.113 & 0.096 \\
\hline B & 0.214 & 0.334 & 0.370 & 0.213 & 0.210 & 0.183 & 0.229 & 0.290 \\
\hline $\mathrm{Fe}$ & 0.003 & 0.003 & 0.008 & 0.001 & 0.007 & 0.003 & 0.002 & 0.003 \\
\hline K & 0.140 & 0.144 & 0.207 & 0.102 & 0.070 & 0.110 & 0.113 & 0.157 \\
\hline Li & 0.323 & 0.451 & 0.483 & 0.360 & 0.335 & 0.334 & 0.328 & 0.401 \\
\hline Mg & 0.006 & 0.000 & 0.015 & 0.000 & 0.000 & 0.000 & 0.003 & 0.007 \\
\hline Mn & 0.003 & 0.002 & 0.005 & 0.000 & 0.006 & 0.002 & 0.001 & 0.002 \\
\hline $\mathrm{Na}$ & 0.255 & 0.328 & 0.411 & 0.210 & 0.266 & 0.210 & 0.256 & 0.310 \\
\hline $\mathbf{P}$ & 0.176 & 0.215 & 0.263 & 0.115 & 0.184 & 0.130 & 0.180 & 0.213 \\
\hline $\mathbf{S i}$ & 0.123 & 0.147 & 0.174 & 0.123 & 0.141 & 0.125 & 0.119 & 0.149 \\
\hline Th & 0.001 & 0.001 & 0.005 & 0.001 & 0.005 & 0.002 & 0.001 & 0.001 \\
\hline U & 0.039 & 0.011 & 0.087 & 0.017 & 0.020 & 0.017 & 0.028 & 0.046 \\
\hline $\mathrm{PH}^{(\mathrm{a})}$ & 10.13 & 10.16 & 10.78 & 9.48 & 10.47 & 10.05 & 9.77 & 10.18 \\
\hline Element & DGWV41 & DGWN42 & DGWN43 & DGWN44 & DGN45 & DGWV46 & DGWN47 & DGWV48 \\
\hline Al & 0.125 & 0.083 & 0.125 & 0.135 & 0.164 & 0.100 & 0.115 & 0.119 \\
\hline B & 0.273 & 0.350 & 0.162 & 0.286 & 0.253 & 0.305 & 0.184 & 0.155 \\
\hline $\mathrm{Fe}$ & 0.011 & 0.002 & 0.028 & 0.004 & 0.009 & 0.006 & 0.025 & 0.003 \\
\hline K & 0.148 & 0.175 & 0.077 & 0.158 & 0.161 & 0.129 & 0.080 & 0.067 \\
\hline Li & 0.382 & 0.480 & 0.306 & 0.418 & 0.365 & 0.392 & 0.307 & 0.316 \\
\hline $\mathrm{Mg}$ & 0.010 & 0.000 & 0.017 & 0.005 & 0.000 & 0.013 & 0.012 & 0.002 \\
\hline Mn & 0.008 & 0.002 & 0.016 & 0.003 & 0.007 & 0.006 & 0.019 & 0.002 \\
\hline $\mathrm{Na}$ & 0.358 & 0.393 & 0.142 & 0.317 & 0.323 & 0.287 & 0.179 & 0.159 \\
\hline P & 0.247 & 0.318 & 0.081 & 0.152 & 0.271 & 0.179 & 0.118 & 0.057 \\
\hline si & 0.157 & 0.162 & 0.126 & 0.129 & 0.153 & 0.133 & 0.130 & 0.120 \\
\hline Th & 0.004 & 0.000 & 0.018 & 0.003 & 0.007 & 0.004 & 0.022 & 0.002 \\
\hline U & 0.062 & 0.015 & 0.048 & 0.039 & 0.047 & 0.049 & 0.040 & 0.004 \\
\hline $\mathrm{PH}^{(a)}$ & 10.34 & 9.19 & 10.19 & 10.29 & 10.37 & 9.83 & 9.15 & 9.13 \\
\hline
\end{tabular}

(a) $\mathrm{pH}$ measured at test termination at $25^{\circ} \mathrm{C}$. 
IABLE 4.8. Average Normalized Releases of Glasses DG-WV33 Through DG-WV48 (28-day MCC $-3,90^{\circ} \mathrm{C}$, Deaerated DIW), $\mathrm{g} / \mathrm{m}^{2}$

\begin{tabular}{|c|c|c|c|c|c|c|c|c|}
\hline Element & DGIN33 & DGN 134 & DGW $\sqrt{35}$ & DGWN36 & DGWV37 & DGN 138 & DGWV39 & DGN40 \\
\hline Al & 0.122 & 0.116 & 0.191 & 0.118 & 0.175 & 0.154 & 0.124 & 0.094 \\
\hline B & 0.317 & 0.689 & 0.538 & 0.313 & 0.287 & 0.229 & 0.420 & 0.411 \\
\hline $\mathrm{Fe}$ & 0.012 & 0.012 & 0.024 & 0.003 & 0.017 & 0.007 & 0.012 & 0.013 \\
\hline K & 0.125 & 0.153 & 0.206 & 0.098 & 0.141 & 0.099 & 0.108 & 0.167 \\
\hline Li & 0.390 & 0.714 & 0.557 & 0.478 & 0.409 & 0.400 & 0.428 & 0.455 \\
\hline Mg & 0.021 & 0.019 & 0.019 & 0.000 & 0.020 & 0.016 & 0.023 & 0.019 \\
\hline Mn & 0.011 & 0.015 & 0.014 & 0.005 & 0.017 & 0.008 & 0.011 & 0.008 \\
\hline Na & 0.342 & 0.578 & 0.591 & 0.263 & 0.369 & 0.263 & 0.379 & 0.419 \\
\hline $\mathbf{P}$ & 0.262 & 0.319 & 0.423 & 0.153 & 0.259 & 0.166 & 0.270 & 0.342 \\
\hline si & 0.166 & 0.199 & 0.230 & 0.151 & 0.185 & 0.157 & 0.151 & 0.195 \\
\hline Th & 0.006 & 0.008 & 0.021 & 0.003 & 0.015 & 0.006 & 0.004 & 0.006 \\
\hline U & 0.058 & 0.016 & 0.053 & 0.039 & 0.032 & 0.026 & 0.037 & 0.086 \\
\hline $\mathrm{pH}^{(\mathrm{a})}$ & 10.27 & 10.35 & 11.06 & 9.69 & 10.82 & 10.40 & 10.01 & 10.39 \\
\hline Element & DGLV41 & DGWV42 & DGWN43 & DGIN44 & DGWV45 & DGWY46 & DGN47 & DGWV48 \\
\hline Al & 0.134 & 0.080 & 0.157 & 0.154 & 0.181 & 0.097 & 0.136 & 0.150 \\
\hline B & 0.385 & 0.483 & 0.282 & 0.509 & 0.343 & 0.850 & 0.312 & 0.225 \\
\hline $\mathrm{Fe}$ & 0.024 & 0.007 & 0.056 & 0.011 & 0.021 & 0.018 & 0.041 & 0.009 \\
\hline$x$ & 0.146 & 0.186 & 0.059 & 0.142 & 0.162 & 0.151 & 0.070 & 0.063 \\
\hline Li & 0.402 & 0.530 & 0.453 & 0.560 & 0.384 & 0.865 & 0.429 & 0.422 \\
\hline Mg & 0.040 & 0.010 & 0.036 & 0.027 & 0.036 & 0.033 & 0.026 & 0.016 \\
\hline Mn & 0.025 & 0.006 & 0.037 & 0.016 & 0.025 & 0.025 & 0.033 & 0.009 \\
\hline $\mathrm{Na}$ & 0.515 & 0.526 & 0.187 & 0.460 & 0.439 & 0.659 & 0.245 & 0.184 \\
\hline $\mathbf{P}$ & 0.314 & 0.443 & 0.114 & 0.213 & 0.343 & 0.305 & 0.162 & 0.081 \\
\hline si & 0.193 & 0.209 & 0.167 & 0.164 & 0.189 & 0.177 & 0.164 & 0.158 \\
\hline Th & 0.010 & 0.001 & 0.039 & 0.008 & 0.019 & 0.026 & 0.038 & 0.009 \\
\hline$u$ & 0.079 & 0.025 & 0.079 & 0.055 & 0.068 & 0.080 & 0.062 & 0.010 \\
\hline $\mathrm{PH}^{(\theta)}$ & 10.63 & 10.52 & 9.36 & 10.50 & 10.64 & 10.08 & 9.40 & 9.43 \\
\hline
\end{tabular}

(a) $\mathrm{pH}$ measured at test termination at $25^{\circ} \mathrm{C}$. 


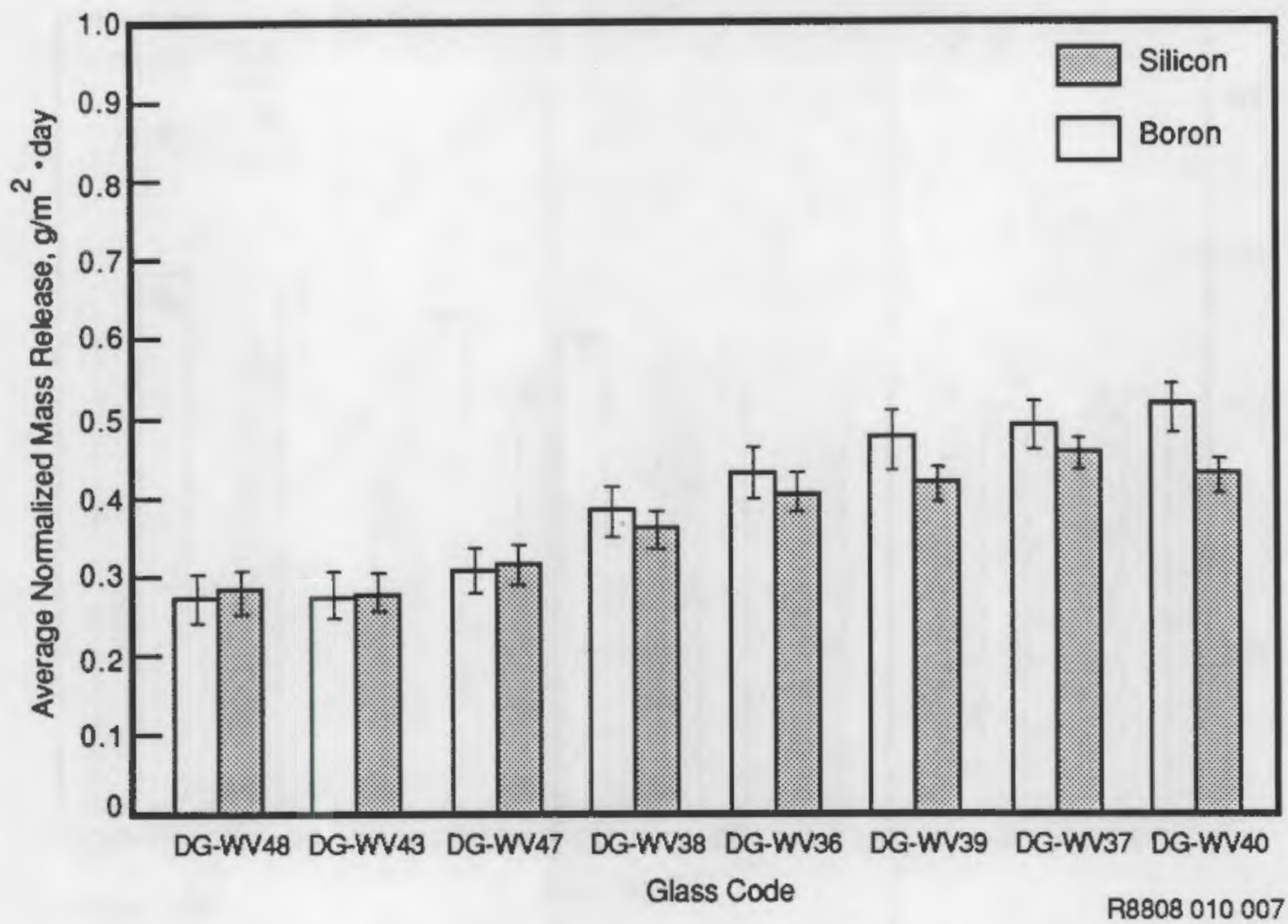

FIGURE 4.9. Comparison of B and Si Average Normalized Releases of Most Durable of FY 1988 Compositional Variability Glasses (Ordered from greatest to least durable based on B release; 28-day MCC-1 test, $90^{\circ} \mathrm{C}$, deaerated DIW)

Some general statements may be made about the leach test results. A few more than half of the glass compositions tested are more durable than the reference composition based on $B$ release. The Th release of the glasses is minimal. Uranium releases were up to 17 times greater than Th releases. The release of alkali follows the $B$ and $\mathrm{Si}$ release trends of the glasses.

The 28 -day MCC-3 releases are roughly 1.5 times as 1 arge as the 7 -day results. If the release rates of the glasses were constant over time, the 28 -day releases would be four times as large. This illustrates the fact that the release rates of the glasses slow considerably with time and leachant saturation with dissolution products.

The MCC-1 release rates are much higher than the MCC -3 release rates. Dissolution rates are a function of glass surface area to leachate volume 


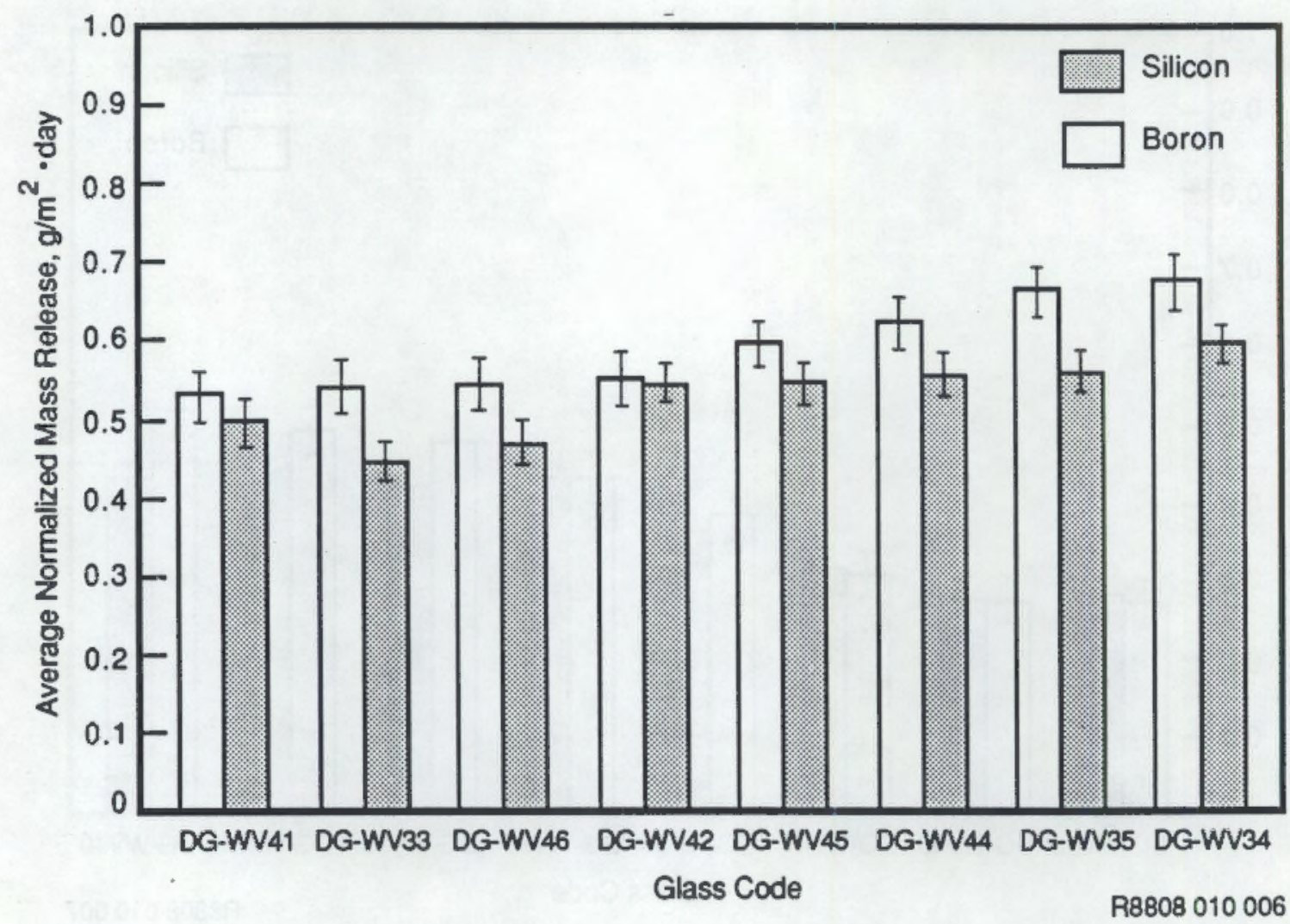

FIGURE 4.10. Comparison of B and Si Average Normalized Releases of Least Durable of FY 1988 Compositional Variability Glasses (Ordered from greatest to least durable based on B release; 28-day MCC-1 test, $90^{\circ} \mathrm{C}$, deaerated DIW)

$(\mathrm{SA} / \mathrm{V})$ ratios as well as test duration $(t)$. At lower values of $(S A / V) \cdot t$, more rapid dissolution is expected to occur. This is reflected in these results.

\subsection{STATISTICAL ANALYSIS AND EMPIRICAL. MODELING OF FY 1988 NORMALIZED RELEASE DATA}

A statistical approach for characterizing chemical durability of glasses within a specified compositional region was applied to the characterization of NBRs from the set of FY $1988 \mathrm{glasses.} \mathrm{Briefly,} \mathrm{the} \mathrm{approach} \mathrm{involved} \mathrm{the}$ following steps: 
- defining the compositional region of glasses to be characterized

- selecting a test matrix of compositions via computer-aided statistical experimental design techniques

- leach testing the test matrix of compositions

- estimating short- and long-term within-1ab and lab-to-1ab uncertainties in the glass analysis, leach testing, and leachate analysis processes

- empirically modeling the leach test results via mixture models

- investigating glass component effects on durability

- constructing statistical confidence and tolerance statements to describe chemical durability over the compositional region.

The statistical confidence and tolerance statements describing durability are made with the fitted empirical models and appropriate estimates of within- and between-lab uncertainty. Although the glass analyses, leach testing, and leachate analyses were all performed by one lab (PNL) at essentially one time, the results are still subject to lab-to-lab variation and short- and long-term within-lab variation. Somewhat different results would have been obtained if the experimental work was performed by PNL or another laboratory at another time. Hence, 1ab-to-lab and short- and long-term within-lab variation must be taken into account in statistically characterizing chemical durability.

In order to construct statistical confidence and tolerance statements about NBR, within- and between-lab variations must be assessed. Specifically, it is necessary to obtain estimates of short-term within-lab, longterm within-lab, and lab-to-lab standard deviations for the leach testing (including test preparation), leachate analysis, and glass analysis processes.

A portion of the FY 1988 experimental effort was directed at replicating leach tests, leachate analyses, and glass analyses to provide estimates of the required short- and long-term within-lab standard deviations. A limited literature review was conducted in order to gather information about within- 
and between-laboratory variations, and the results are summarized in Appendix $C$. The estimates of short- and long-term within-lab standard deviations that resulted from the FY 1988 efforts are summarized in Appendix D.

However, these results were obtained too late to be used in developing the confidence and tolerance bands discussed later in this section. Still, they compare very well with the standard deviations obtained from the literature survey.

Table $C .8$ of Appendix $C$ contains a summary of the percent relative standard deviation (\%RSD) for the various types of uncertainty associated with determining NBR. Although some of the \%RSDs are based on limited data, it is clear that short-term within-lab uncertainty is smaller than long-term within-1ab uncertainty, which in turn is smaller than lab-to-1ab uncertainty. Further, although the relative magnitudes of the various types of uncertainty are somewhat uncertain, it seems apparent that the combined uncertainty is probably at least $20 \%$, and could be considerably higher depending on the actual lab-to-lab uncertainty.

For the purposes of constructing confidence and tolerance statements about the normalized releases, the \%RSDs given in Table 4.9 were used. Because the magnitude of lab-to-lab uncertainty is not well-known at this time, three values were considered, $10 \%, 20 \%$, and $50 \%$, as shown in Table 4.9.

\subsubsection{Linear Mixture Models Fit to Normalized Boron Release Data}

A linear mixture model of the form given by Equation (4.1) was fitted to the NBR data from the 28-day MCC-1 and 7-day MCC-3 tests. The fitted 1 inear mixture model for the 28 -day MCC-1 test is

$$
\begin{aligned}
\mathrm{NBR}= & -78.02 \mathrm{Al}_{2} \mathrm{O}_{3}+26.84 \mathrm{~B}_{2} \mathrm{O}_{3}+56.06(\mathrm{BaO}+\mathrm{CaO}+\mathrm{MgO})+ \\
& 30.86 \mathrm{Fe}_{2} \mathrm{O}_{3}+151.07\left(\mathrm{~K}_{2} \mathrm{O}+\mathrm{Li}_{2} \mathrm{O}+\mathrm{Na}_{2} \mathrm{O}\right)+72.97 \mathrm{MnO}_{2}- \\
& 46.29 \mathrm{P}_{2} \mathrm{O}_{5}-30.00 \mathrm{SiO}_{2}+23.06 \mathrm{ThO}_{2}+35.90 \mathrm{UO}_{2}+ \\
& 5.37 \text { thers, }
\end{aligned}
$$


IABLE 4.9. Relative Standard Deviations and Degrees of Freedom Used as the Basis for the Confidence and Tolerance Statements (WV-8801-Based Compositional Variation Region)

\begin{tabular}{|c|c|c|c|c|}
\hline \multirow{2}{*}{ Source of Uncertainty } & \multicolumn{2}{|c|}{$\frac{M C C-1,28-D a y}{d f}$} & \multicolumn{2}{|c|}{ MCC-3, 7-Day } \\
\hline & $\%$ RSD & $d f$ & $\%$ RSD & $d f$ \\
\hline \multicolumn{5}{|l|}{ Short-term Within-Lab } \\
\hline $\begin{array}{l}\text { - Leach Testing and } \\
\text { Leachate Analysis }\end{array}$ & $3 \%$ & 7 & $3 \%$ & 30 \\
\hline - Glass Analysis $\left(\mathrm{B}_{2} \mathrm{O}_{3}\right)$ & $2.5 \%$ & 17 & $2.5 \%$ & 17 \\
\hline \multicolumn{5}{|l|}{ Long-Term Within-Lab } \\
\hline $\begin{array}{l}\text { - Leach Testing and } \\
\text { Leachate Analysis }\end{array}$ & $6 \%$ & 4 & $11 \%$ & 3 \\
\hline - Glass Analysis $\left(\mathrm{B}_{2} \mathrm{O}_{3}\right)$ & $2 \%$ & 17 & $2 \%$ & 17 \\
\hline Total Within-Lab & $7.5 \%$ & 9 & $11.8 \%$ & 4 \\
\hline \multicolumn{5}{|l|}{ Lab-to-Lab } \\
\hline $\begin{array}{l}\text { - Leach Testing and } \\
\text { Leachate Analysis }\end{array}$ & $\begin{array}{l}10 \% \\
20 \% \\
50 \%\end{array}$ & $\begin{array}{r}6 \\
12 \\
16\end{array}$ & $\begin{array}{l}10 \% \\
20 \% \\
50 \%\end{array}$ & $\begin{array}{r}6 \\
12 \\
16\end{array}$ \\
\hline - Glass Analysis $\left(\mathrm{B}_{2} \mathrm{O}_{3}\right)$ & $5 \%$ & 2 & $5 \%$ & 2 \\
\hline Total Within-Lab \& Lab-to-Lab & $\begin{array}{l}13.5 \% \\
21.9 \% \\
50.8 \%\end{array}$ & $\begin{array}{l}14 \\
16 \\
17\end{array}$ & $\begin{array}{l}16.3 \% \\
23.8 \% \\
51.6 \%\end{array}$ & $\begin{array}{l}10 \\
17 \\
18\end{array}$ \\
\hline
\end{tabular}

Notes 1. The \%RSD and Degrees of Freedom (df) values above were chosen based on the findings in Appendix $B$.

2. Three values for $1 a b-t o-7 a b$ leach testing and leachate analysis uncertainty were chosen because of the extreme range in \%RSD values for the three applicable cases found during the literature review (see Table B.4). The $10 \%, 20 \%$, and $50 \%$ values selected above are somewhat less than the $19 \%, 31 \%$, and $64 \%$ values given in Table B.4, because the latter values also include long-term within-lab variation.

3. The df associated with the total \%RSD of NBR were obtained as a weighted average of the df of each contributing source of variation according to Satterthwaite's formula (Montgomery 1976). 
with an $R^{2}$ value of 0.95 . The fitted 1 inear mixture model for the 7 -day MCC -3 test is

$$
\begin{aligned}
\mathrm{NBR}= & -1.86 \mathrm{Al}_{2} \mathrm{O}_{3}+0.34 \mathrm{~B}_{3} \mathrm{O}_{3}+3.02(\mathrm{BaO}+\mathrm{CaO}+\mathrm{MgO})+ \\
& 0.54 \mathrm{Fe}_{2} \mathrm{O}_{3}+2.24\left(\mathrm{~K}_{2} \mathrm{O}+\mathrm{Li}_{2} \mathrm{O}+\mathrm{Na}_{2} \mathrm{O}\right)+2.84 \mathrm{MnO}_{2}- \\
& 0.77 \mathrm{P}_{2} \mathrm{O}_{5}-0.40 \mathrm{SiO}_{2}+0.88 \mathrm{ThO}_{2}+1.59 \mathrm{UO}_{2}+ \\
& 0.17 \text { Others, }
\end{aligned}
$$

with an $R^{2}$ value of 0.97 . $R^{2}$ measures the proportion of variation in NBR values explained by a fitted model, so it is clear that the linear mixture models (4.4) and (4.5) fit the data quite well. Statistical tests based on short-and long-term within-lab uncertainties indicate that the fitted models do not have a significant lack-of-fit.

\subsubsection{Component Effects Plots}

The effects of varying the 11 individual oxide components are displayed in the effects plots (Piepel 1982) of Figures 4.11 and 4.12 , which correspond respectively to the fitted linear mixture models $(4.4)$ and (4.5). Each effect curve displays the effect of changing the associated component over its allowable range (as defined by the constraints in Table 3.6).

From the practical standpoint of characterizing chemical durability over the compositional region, the total effects are probably of most interest. Figures 4.11 and 4.12 show for both the 28-day MCC-1 and 7-day MCC-3 tests that $\mathrm{Al}_{2} \mathrm{O}_{3}, \mathrm{SiO}_{2}$, and $\mathrm{P}_{2} \mathrm{O}_{5}$ have the largest negative total effects on NBR increasing their levels lowers NBR), while alkalis have the largest positive total effect (i.e., increasing the alkali level raises NBR). The remaining components appear to have less significant or negligible effects within the compositional region of Table 3.6.

\subsubsection{Confidence and Tolerance Statements About Normalized Boron Release Over the Composition Region}

The final step in the statistical approach for characterizing NBR from the $2 \mathrm{~B}$-day MCC-1 and 7-day MCC-3 tests is to construct statistical confidence and tolerance statements from the fitted NBR models and the estimates of 


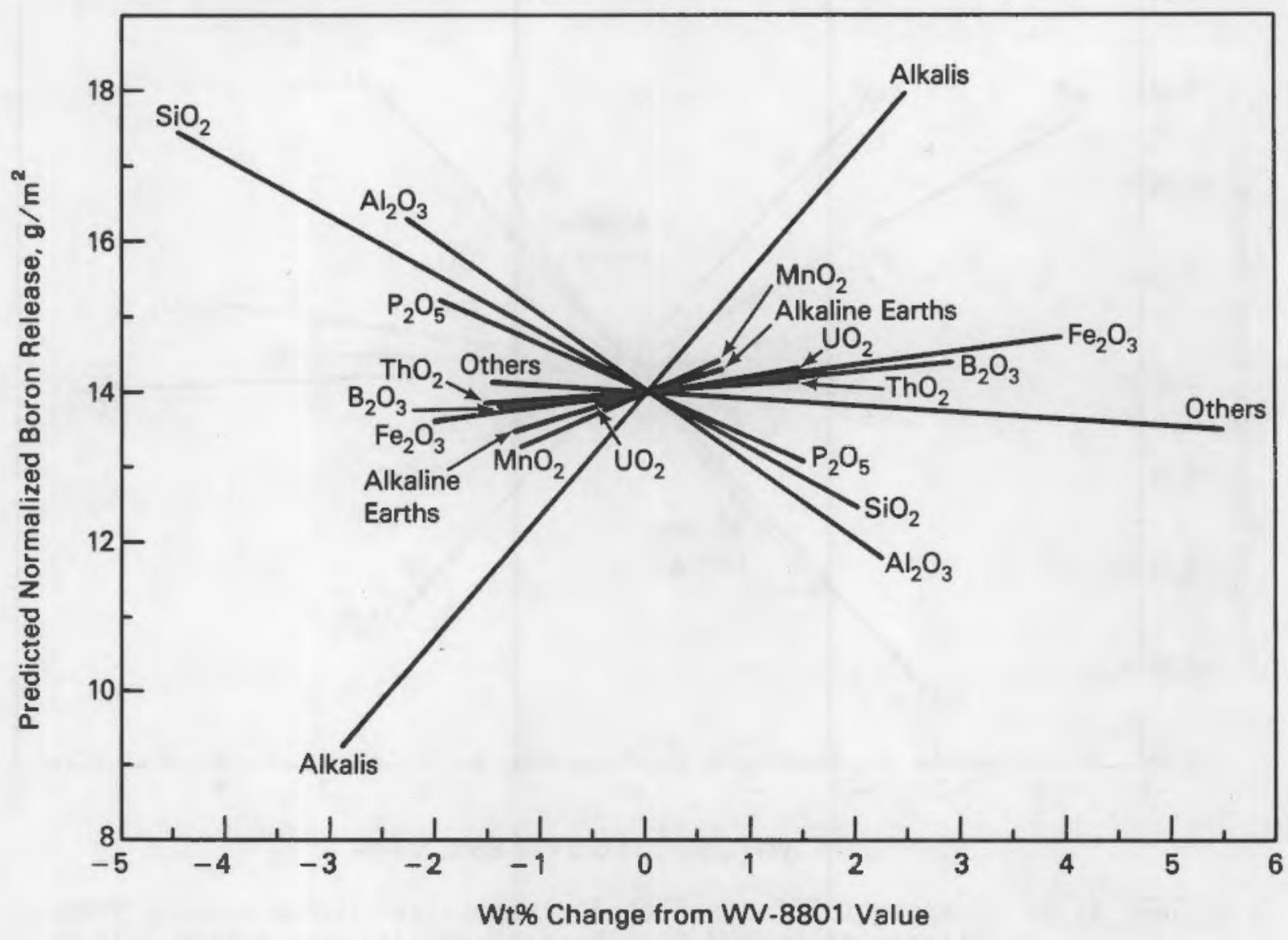

FIGURE 4.11. Component Effects Plot for Normalized Boron Release from Glasses in the WV-8801-Based Compositional Region Tested with the 28-Day MCC-1 Test

short-term within-1ab, 1ong-term within-1ab, and lab-to-lab uncertainties. Specifically, one-sided upper $95 \%$ confidence and $95 \% / 95 \%$ tolerance bands were constructed for the fitted linear mixture models given in Equations (4.4) and (4.5), using the uncertainties given in Table 4.9. The formulas for constructing the confidence and tolerance bands are given in Appendix A.

The interpretation of the one-sided confidence and tolerance bands is as follows:

95\% One-Sided Upper Confidence Band: provides 95\% confidence that

all glasses in the compositional region have true (or average) NBR less than the band. 


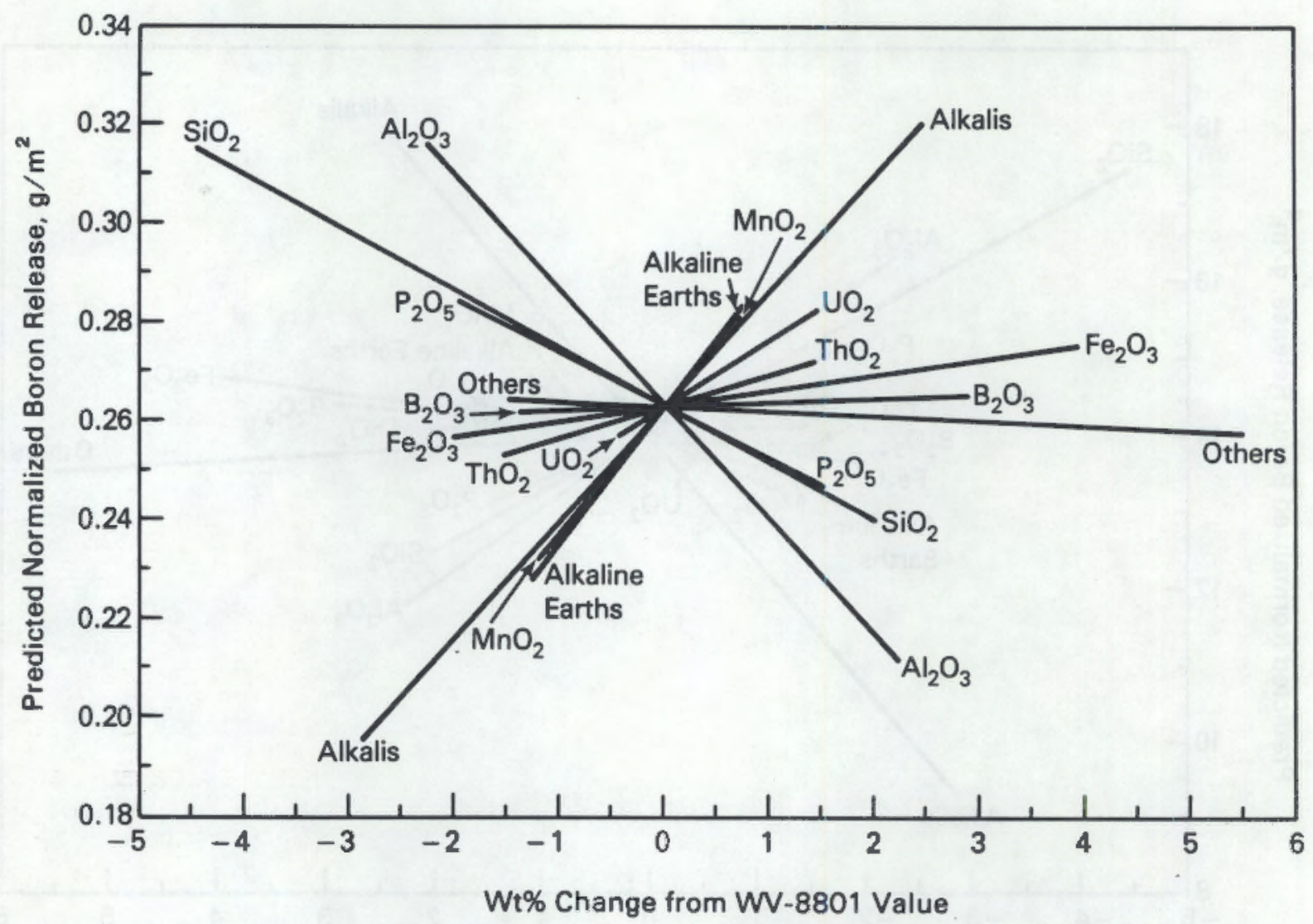

FIGURE 4.12. Component Effects Plot for Normalized Boron Release from Glasses in the WV-8801-Based Compositional Region Tested with the 7-Day MCC-3 Test

95\%/95\% One-Sided Upper Tolerance Band: provides at 1east $95 \%$ confidence that all glasses in the compositional region will have NBR less than the band $95 \%$ of the time.

A confidence band makes a statement about the mean of the NBR distribution for each glass in the region, while a tolerance band makes a statement about the 95th percentile of the NBR distribution for each glass in the region. One-sided upper confidence and tolerance bands are constructed because the concern is only about how large NBR may be, not how small it may be. The fitted models (4.4) and (4.5) can be used to predict the largest NBR over the region, and the confidence and tolerance bands can be applied to yield confidence and tolerance statements about the largest value of NBR over the region. 
Because of the linearity of models (4.4) and (4.5), the maximum values on the fitted, $95 \%$ confidence and $95 \% / 95 \%$ tolerance surfaces occur at one of the extreme vertices of the compositional region. The extreme vertices were generated as one step of selecting the test matrix. The fitted models (4.4) and (4.5) and the corresponding one-sided upper 95\% confidence and 95\%/95\% tolerance band formulas were applied to the extreme vertices using the various combinations of uncertainties in Table 4.9.

The largest values of NBR obtained from the fitted models and the confidence and tolerance band formulas are given in Table 4.10. Although results are given for the case of within-lab uncertainty (i.e., without labto-lab uncertainty), those values are given for comparison purposes only. Lab-to-lab variation/uncertainty cannot be ignored. The results that include $10 \%$ lab-to-lab uncertainty may be viewed as an optimistic or "best case" possibility, and the results that include $50 \%$ lab-to-1ab uncertainty may be viewed as a pessimistic or "worst case" possibility. The results based on $20 \%$ lab-to-lab uncertainty might be considered as a more realistic or "middle ground" possibility.

All of the confidence and tolerance values on NBR for the 28-day MCC-1 test are above $28 \mathrm{~g} / \mathrm{m}^{2}$, the level corresponding to the $1 \mathrm{~g} / \mathrm{m}^{2} \cdot$ day criterion suggested by the Nevada Nuclear Waste Storage Investigations Project. This criterion in listed in the Waste Acceptance Preliminary Specifications (WAPs). The applicable specification states that the normalized release rates of $\mathrm{Na}, \mathrm{Si}, \mathrm{B}, \mathrm{U}$, and $\mathrm{CS}$ must be below $1 \mathrm{~g} / \mathrm{m}^{2}$-day or $28 \mathrm{~g} / \mathrm{m}^{2}$ in a 28 -day MCC- 1 test in DIW at $90^{\circ} \mathrm{C}$. Thus, there are glasses in the WV-8801-based compositional region that may not meet this criterion. Rather than conclude from this that the compositional region around WV-8801 is too large, it may be that the $1 \mathrm{~g} / \mathrm{m}^{2}$.day criterion needs to be reassessed. It is not clear whether the $1 \mathrm{~g} / \mathrm{m}^{2}$.day criterion was suggested with statistical characterization of chemical durability in mind. Several options, including a smaller composition region, need for statistical variability consideration, reduction in analytical variability, investigation of an additional composition region, or reassessment of the proposed limit, should be further investigated. It is clear that lab-to-lab and within-lab uncertainties cannot be ignored, either 
TABLE 4.10. Confidence and Tolerance Band Statements for Maximum Normalized Boron Releases $\left(\mathrm{g} / \mathrm{m}^{2}\right)$ Over the WV-8801-Based Compositional Variation Region

\section{8-Day MCC-1 7-Day MCC-3}

Predicted by Linear Mixture Models

95\% Upper Confidence Band

- Short- and Long-Term Within-Lab Uncertainty

- Short- and Long-Term Within-Lab $+10 \%$ Lab-to-Lab Uncertainty

- Short- and Long-Term Within-Lab $+20 \%$ Lab-to-Lab Uncertainty

- Short- and Long-Term Within-Lab + $50 \%$ Lab-to-Lab Uncertainty

95\%/95\% Upper Tolerance Band

- Short- and Long-Term Within-Lab Uncertainty

- Short- and Long-Term Within-Lab $+10 \%$ Lab-to-Lab Uncertainty

- Short- and Long-Term Within-Lab + 20\% Lab-to-Lab Uncertainty

- Short- and Long-Term Within-Lab $+50 \%$ Lab-to-Lab Uncertainty
22.2

0.46

29.3

34.0

$0.75^{(a)}$

41.1

0.85

66.1 1.31

34.6

42.3

$0.98^{(a)}$

54.1

1.13

95.7

1.91

(a) These values are smaller than the values that only account for within-lab variation because of differences in the degrees of freedom (see Table 4.9).

in characterizing the chemical durability of a region of glass compositions, or in the selection of an acceptance criterion.

Long-term within- $1 a b$ and $1 a b-t o-1 a b$ variations were seen to be significant contributors to the uncertainty of the chemical durability of glasses within the region explored. Additional information on the magnitude of these 
uncertainties is needed to obtain more defensible confidence and tolerance statements. This is especially true of lab-to-lab variation.

\subsection{MICROSTRUCTURE OF FY 1988 SET OF GLASSES}

In this variability study, the compositions are not being varied on a one-at-a-time basis; therefore, there are many possible interactions which confound simple interpretations of the presence of various phases. Instead of intercomparing a 11 of the $16 \mathrm{glasses}$ with each other, it was judged more reasonable to use glass DG-WV33 (WV-8801) as the internal standard for comparison purposes; this is the "target" composition upon which the compositional variability study was based. After first closely examining this glass to ensure that it possessed a fairly typical concentration of phases which had been seen previously, the micrographs for each of the other glasses in the study were placed side-by-side with those for DG-WV33, and any deviations were noted. Table 4.11 summarizes these observations. Figures 4.13 through 4.15 are micrographs of DG-WV33, DG-WV44, and DG-WV47 showing typical crystalline formations.

In general, the glasses contained small amounts of relatively small and widely scattered crystalline phases. Thoria crystallites were present in essentially all of the glasses and it is likely that these crystallites are an artifact of the glass fabrication. Thoria is a very stable oxide and thus slow to dissolve; these inclusions most likely represent incompletely dissolved feed material rather than material precipitated from solution in the glass. Additional phases were provided by noble metals such as Pd and Rh, which have very low solubilities in glasses and are not incorporated in the glass during melting. The remaining crystalline phases, such as various spinels, are typically deposited from glass melts because they are more stable as crystals than when dissolved in the glass.

One exception to this general trend in microstructure was glass DG-WV41, which was free from non-glass phases of any type. It is not clear why this occurred. As shown in Table 3.7, DG-WV41 was relatively low in $\mathrm{Al}_{2} \mathrm{O}_{3}$, probably giving it good fluidity. It was also quite well-fluxed with alkali oxides, which probably also enhanced its fluidity. However, the method by 
TABLE 4.11. Optical and SEM Microscopy Observations of Glasses DG-WV33 Through DG-WV48

Glass \#

DG-WV33

(WV-8801)

DG-WV34

DG-WV35

DG-WV36

DG-WV37

DG-WV38

DG-WV39

DG-WV40

DG-WV41

DG-WV42

DG-WV43
Comments

Widely scattered globular masses of small particles identified as undissolved Th02, not in a cubic habit, plus a low concentration of globular metallics(a) identified as either Rh or Ru and phases containing $\mathrm{Si}, \mathrm{Ru}, \mathrm{Al}, \mathrm{Fe}$, and $\mathrm{K}$. (b) This glass is shown in Figure 4.13.

Has widely scattered metallics, less concentrated than DGWV33. Hexagonal phase containing $\mathrm{Si}, \mathrm{Rh}, \mathrm{Pd}, \mathrm{Cr}, \mathrm{Fe} .(\mathrm{b})$ Also spinel containing $\mathrm{Cr}, \mathrm{Fe}$, and $\mathrm{Ni}$.

Small crystals visible optically at low magnification, mottled background appearance at high magnification. Very welldeveloped cubic $\mathrm{ThO}_{2}$ crystals in globular zones, other scattered small spinel crystals. No composition difference corresponding to mottled appearance visible on SEM.

About same as DG-WV33, but many more very small crystals, mostly acicular but some cubic. Some undissolved $\mathrm{ThD}_{2}$, cubic crystals are $\mathrm{Fe}-\mathrm{Cr}-\mathrm{Nj}$ spinel, with some dissolved $\mathrm{Rh}$. Few $\mathrm{Ru}-\mathrm{Si}-\mathrm{Fe}$ crystals, (b) aciculars mostly $\mathrm{Si}-\mathrm{Fe}$.

Slightly more crystalline than DG-WV33, small and widely distributed. Phases are $\mathrm{Ru}-\mathrm{Pd}$ metallic, $\mathrm{Fe}-\mathrm{Cr}-\mathrm{Ni}$ spinel, $\mathrm{Rh}$ metallic, Ru metallic, Ru-Pd metallic, and acicular $\mathrm{Fe}-\mathrm{Si}(\mathrm{b})$ crystals like DG-WV36.

Crystals smaller and more widely dispersed than DG-WV33. Some mottled appearance at 500X optical. Few large undissolved $\mathrm{ThO}_{2}$ particles, $\mathrm{Fe}-\mathrm{Ni}-\mathrm{Cr}$ spinel, Si-Pd metallic, Ru-Si metallics, spinel containing Ru.

Very few crystalline phases. Widely scattered crystals are mostly Ru or a mixture of Ru crystals and Ru-Rh ones.

Very similar to DG-WV33. Few large undissolyed particles of $\mathrm{ThO}_{2}$, with obvious cubic crystals. Si-Ru-Fe (b) metallic, Ru metâlic.

Specimen is absolutely clean--no crystalline phases.

Less metallics than DG-WV33, mottled background phase, very smal1. Pd metallics, $\mathrm{Cr}-\mathrm{Fe}-\mathrm{Ni}$ spinel, Rh metallics, small number of undissolved $\mathrm{ThO}_{2}$ particles, not well-crystallized.

Appearance and frequency of grystals much like DG-WV33, additional $\mathrm{Si}-\mathrm{Ru}-\mathrm{Fe}$ phase, $(\mathrm{b})$ some undissolved $\mathrm{ThO}_{2}$. 
TABLE 4.11. (contd)

Glass \#

DG-WV44

DG-WV45

DG-WV46

DG-WV47

DG-WV48
Comments

Crystals are very small, fairly prominent mottled appearance. $\mathrm{Si}$-Ru-Fe metallics, with $\mathrm{Si}-\mathrm{Fe}$ acicular crystals attached. Some undissolved $\mathrm{ThO}_{2}$. Glass contains tiny spheroids, possible liquid-liquid separation where spheroids are fainter gray features in background. These features are shown in Figure 4.14.

Crystals appear similar to DG-WV33, but at lower frequency. Some Ru metallics, with attached acicular Fe-Si crystals, some Fe spinels. A few areas of undissolved $\mathrm{ThO}_{2}$, not wellcrystallized.

Very few crystals visible. Rh-Pd metallics, Fe-Rh crystals, $\mathrm{Si}-\mathrm{Ru}$ crystals.

Very few metallics, less than DG-WV33. Main feature is small $\mathrm{Si}-\mathrm{Ru}-\mathrm{Fe}$ metallics, (b) surrounded by radial acicular crystals of $\mathrm{Si}-\mathrm{Fe}$. This feature is shown in Figure 4.15. Glass contains small spheroids. Some undissolved $\mathrm{ThO}_{2}$, well crystallized.

Similar to DG-WV33. Scattered metallics, mottled background. Ru-Rh metallics, Fe-Cr-Ni spinels, Pt-Rh metallics. Some undissolved $\mathrm{ThO}_{2}$, not crystalline. Some small spheroids, like DG-WV44.

(a) In this table, the term "metallic" is used in a common manner which may not be precise, i.e., metallics refer to phases which appear as bright against the glass background in optical microscopy. The high concentration of heavy metals usually makes these phases bright in the electron microscope although, as in the case of the spinels, they may not be actual metals.

(b) $\mathrm{Si}$ in these phases may be caused by electron shine of material in contact with the phase. The electron beam penetrates to a depth of approximately $5 \mu \mathrm{m}$ and therefore the analysis can reflect the composition of material touching the phase in addition to the phase or area being investigated with the electron probe.

which these glasses were made would lessen these fluidity effects, since melting was started at $1150^{\circ} \mathrm{C}$ and temperatures were raised until experienced personnel judged the viscosity to be in the 50 to 100 poise range. Since all the glasses were melted at a comparable viscosity, it is not obvious that these types of compositional differences should have resulted in a glass that 


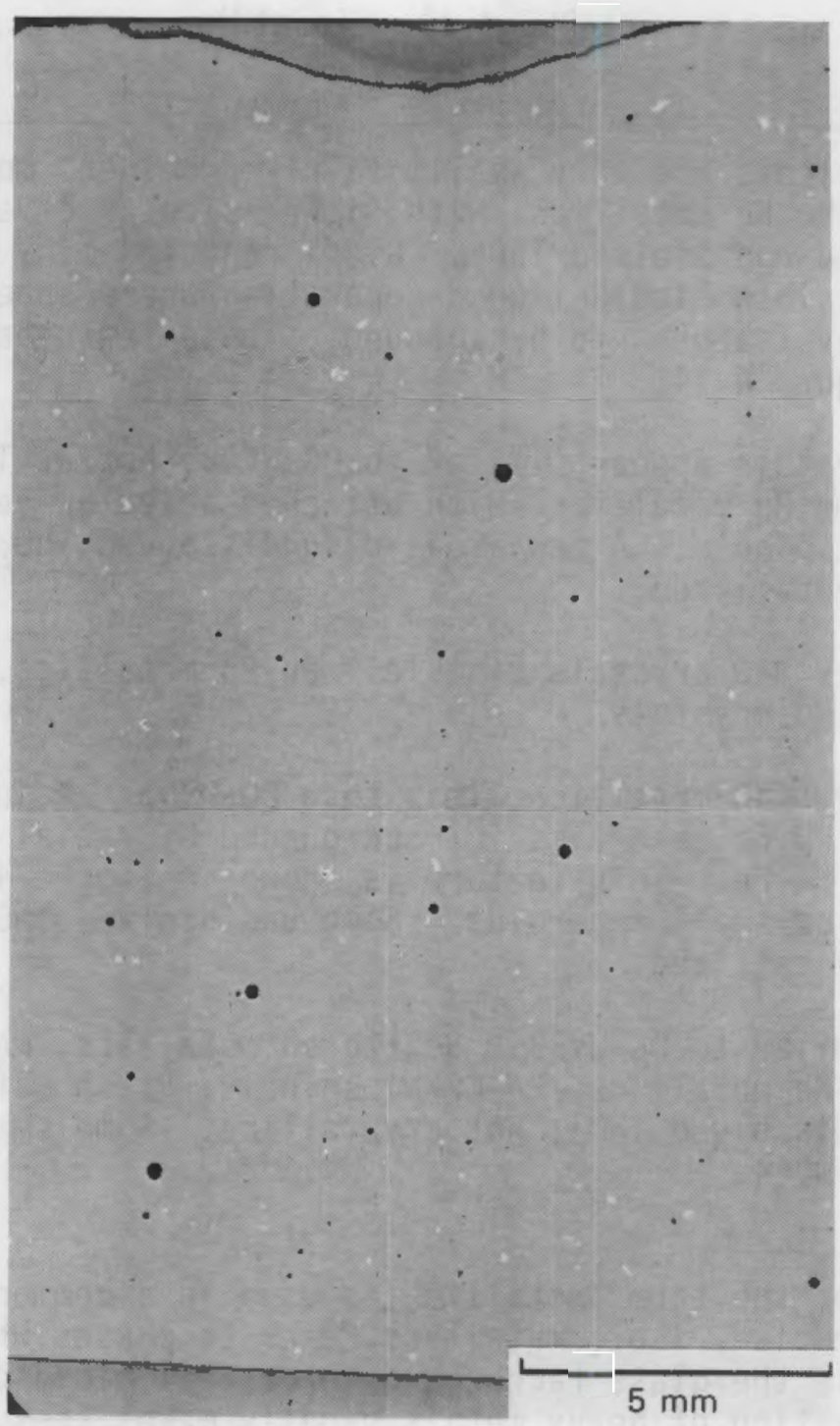

FIGURE 4.13. Optical Micrograph (6.5 X) of DG-WV33 (WV-8801). Black dots are bubbles, white areas are "metallics" mentioned in Table 4.11.

was free from crystals. Also, excessively fluid glasses can be prone to crystallization because of the high diffusion rates thus provided. However, the decrease in $\mathrm{Al}_{2} \mathrm{O}_{3}$ increases the solubility of elements by increasing the number of open sites in the glass matrix.

The lack of crystallinity in glass DG-WV41 may have been due to a greater ability of this lower $\mathrm{Al}_{2} \mathrm{O}_{3}$, higher alkali glass to maintain glass components in solution. Note that although $\mathrm{ThO}_{2}$ was on high in this glass, 


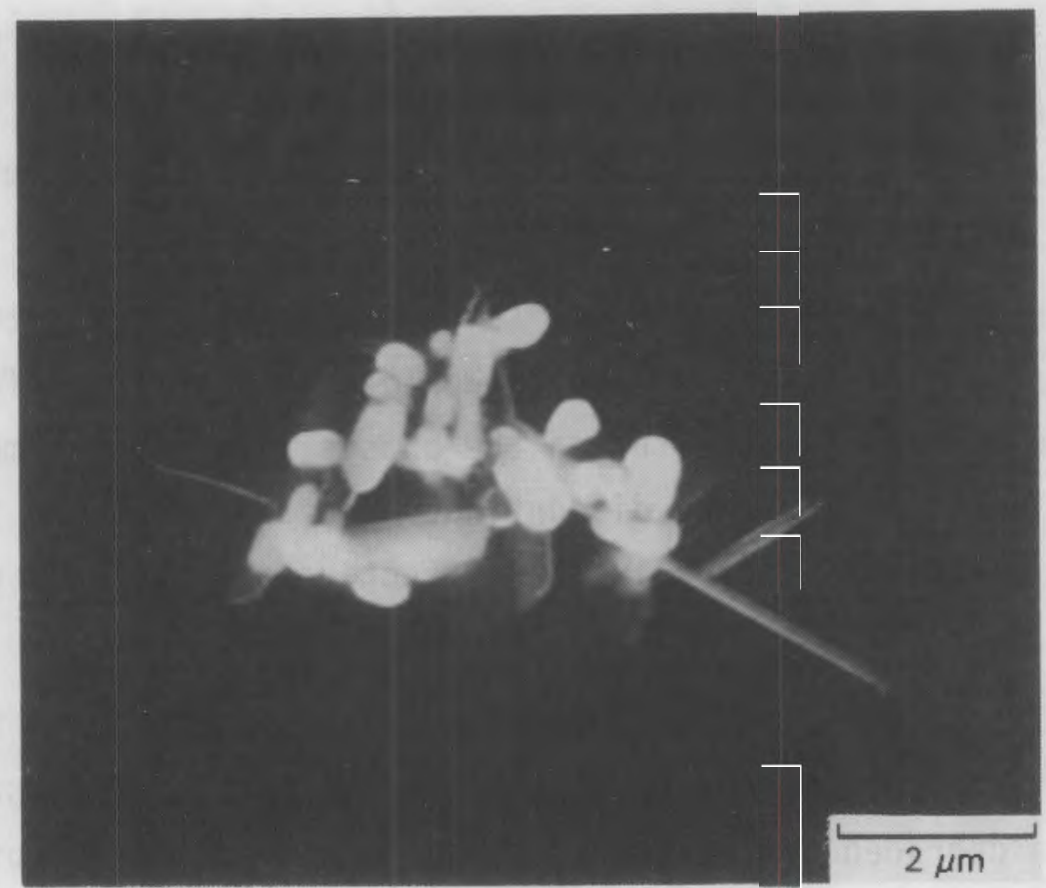

FIGURE 4.14. SEM Micrograph of DG-WV44 Showing Metallic Surrounded by Acicular Crystals, Plus Spheroids in Surrounding Glass Which May be Evidence of Liquid-Liquid Phase Separation $(10,000 \mathrm{X})$

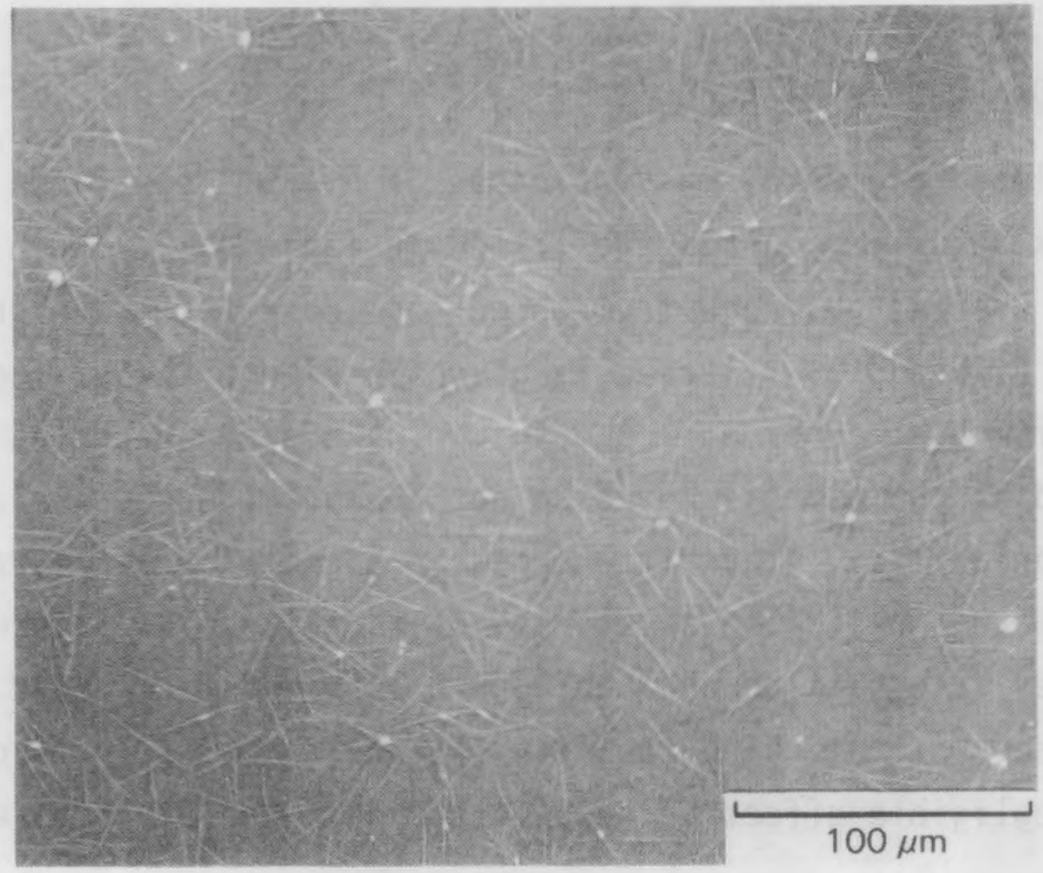

FIGURE 4.15. SEM Micrograph of DG-WV47 Showing Abundance of Metallics Surrounded by Acicular Crystals (300 X) 
all of it was dissolved. Also, this glass was relatively low in $\mathrm{Fe}$, probably decreasing its propensity to form Fe-bearing crystals. The lack of noble of metal phases may be related to the low concentrations of noble metals in the glass (they are part of the "others" component in Table 4.7).

From a practical point of view, it is unlikely that the scattered small crystalline phases noted in these samples would have a marked effect on durability. The materials constituting the phases are probably more durable than the host glass, and they are discontinuous in any event, so they do not provide a means of grossly increasing the effective surface area of the glasses.

However, if a sufficient amount of these phases form during the melting process (rather than during cooling), it is possible that processability of the glass may be degraded or that these phases might settle out of the glass and accumulate in the melter as a sludge. The examination of batch melting sequences and eludge accumulation, which is a complex matter dependent on melter shape and throughput and particle size, shape, and density, are beyond the scope of this work. Further study of the formation of these crystals should be undertaken.

\subsection{GLASS REDOX ADJUSTMENT EFFECTS}

The normalized elemental mass releases of Al, B, Cs, Li, Na, Si, Th, and $U$ for the redox-adjusted glasses are listed in Table 4.12. Each value given represents the average obtained from three replicate tests. A graphical representation of $\mathrm{B}$ and $\mathrm{Si}$ releases is given in Figure 4.16. The error bars represent experimental error of \pm two sds. The sds are based on replicate tests performed at the same time and do not include the time-related component of variability. The differences in $\mathrm{B}$ and $\mathrm{Si}$ releases among the glasses tested are small. The similarity of the $\mathrm{Si}$ and $\mathrm{B}$ releases suggests that the glasses have similar chemical durability and that redox state has negligible effect on chemical durability. Statistical analysis of variance confirms the negligible effect of redox state on $B$ and $S i$ releases.

The final $\mathrm{pH}$ of the leachate appears to increase with the increasing $\mathrm{Fe}^{2+} / \mathrm{Fe}^{3+}$ of the glass leached. This could be caused by the oxidation of 
TABLE 4.12. Average Normalized Elemental Mass Releases of Redox Adjusted Glasses (7-day MCC $-3,90^{\circ} \mathrm{C}$, Deaerated DIW), $\mathrm{g} / \mathrm{m}_{2}$

\begin{tabular}{lllll} 
& \multicolumn{4}{c}{$\mathrm{Fe}^{2+} / \mathrm{Fe}^{3+}$} \\
\cline { 2 - 5 } Element & $\underline{0.068}$ & $\underline{0.126}$ & $\underline{0.236}$ & $\underline{0.424}$ \\
$\mathrm{Al}$ & 0.119 & 0.113 & 0.114 & 0.121 \\
$\mathrm{~B}$ & 0.212 & 0.209 & 0.212 & 0.237 \\
$\mathrm{Cs}$ & 0.092 & 0.101 & 0.081 & 0.067 \\
$\mathrm{Fe}$ & 0.003 & 0.002 & 0.003 & 0.003 \\
$\mathrm{~K}$ & 0.020 & 0.056 & 0.026 & 0.095 \\
$\mathrm{Li}$ & 0.274 & 0.269 & 0.269 & 0.295 \\
$\mathrm{Mg}$ & 0.000 & 0.000 & 0.000 & 0.003 \\
$\mathrm{Mn}$ & 0.002 & 0.002 & 0.002 & 0.003 \\
$\mathrm{Na}$ & 0.209 & 0.203 & 0.215 & 0.249 \\
$\mathrm{P}$ & 0.177 & 0.173 & 0.171 & 0.182 \\
$\mathrm{Si}$ & 0.116 & 0.112 & 0.112 & 0.121 \\
$\mathrm{Th}$ & 0.000 & 0.000 & 0.000 & 0.000 \\
$\mathrm{Ti}$ & 0.001 & 0.001 & 0.000 & 0.001 \\
$\mathrm{U}$ & 0.024 & 0.023 & 0.021 & 0.025 \\
$\mathrm{pH}(\mathrm{a})$ & 9.64 & 9.76 & 9.82 & 9.91
\end{tabular}

(a) $\mathrm{pH}$ measured at test termination at $25^{\circ} \mathrm{C}$.

$\mathrm{Fe}^{2+}$ in the leachate. As $\mathrm{Fe}^{2+}$ goes into solution, it is oxidized by dissolved $\mathrm{O}_{2}$ in the following reaction:

$$
\mathrm{O}_{2}+4 \mathrm{H}^{+}+4 \mathrm{Fe}^{2+} \rightarrow 4 \mathrm{Fe}^{3+}+2 \mathrm{H}_{2} \mathrm{O}
$$

This reaction consumes $\mathrm{H}^{+}$which in turn increases the $\mathrm{pH}$. With greater $\mathrm{Fe}^{2+}$ / $\mathrm{Fe}^{3+}$ ratios, more $\mathrm{Fe}^{2+}$ is available for oxidation. The greater the amount of $\mathrm{Fe}^{2+}$ oxidized, the greater the increase in solution $\mathrm{pH}$. Calculations comparing available $\mathrm{Fe}^{2+}$ concentrations and $\mathrm{H}^{+}$consumption support this theory. 


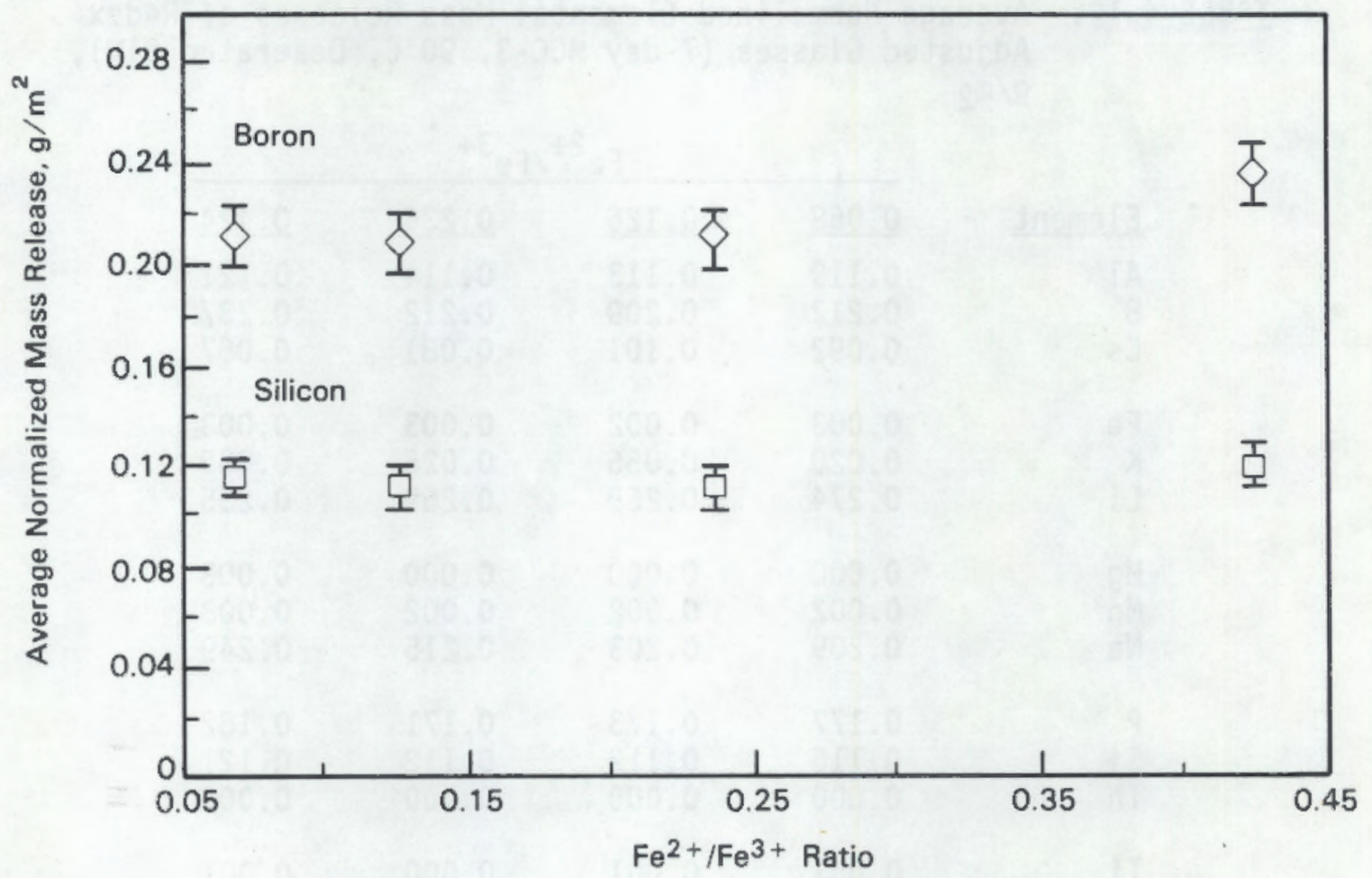

FIGURE 4.16. Comparison of Si and B Normalized Mass Releases from RedoxAdjusted Glasses. Modified MCC -3 test, $90^{\circ} \mathrm{C}$, deaerated deionized water, 7-day.

\subsection{THERMAL HISTORY EFFECTS}

Glasses DG-WV11R through DG-WV14R were heat treated under simulated canister and isothermal conditions and then leach tested to determine glass durability.

\subsubsection{Simulated Canister Cooling}

The glass microstructure and durability were determined from normalized element release data, for glasses subjected to slow-cooling. The glass microstructure and durability results are discussed below.

\section{Glass Microstructure}

Cubic spinel-type crystals [ $\left.(\mathrm{Fe}, \mathrm{Ni})(\mathrm{Cr}, \mathrm{Fe})_{2} \mathrm{O}_{4}\right]$ were observed in all heat-treated glasses with SEM/EDX and verified with XRD. These crystals contained $\mathrm{Cr}, \mathrm{Ni}$, and $\mathrm{Fe}$. Some also contained small amounts of $\mathrm{Mn}$. These crystals were scattered evenly throughout the glass. They ranged in size 
from approximately 5 to $10 \mu \mathrm{m}$. Ruthenium inclusions and fluorite crystals $\left(\mathrm{ThO}_{2}+\mathrm{UO}_{2}\right)$ were also observed in all glasses. The $\mathrm{Ru}$ inclusions appeared to act as nucleation sites for crystal growth. The fluorite crystals measured approximately 25 to $50 \mathrm{\mu m}$ across; the Ru inclusions measured approximately 0.3 to $0.8 \mu \mathrm{m}$. Crystals which appear to be hematite $\left[(\mathrm{Cr}, \mathrm{Fe})_{2} \mathrm{O}_{3}\right]$ were observed in all glasses with SEM/EDX. They were not detected in four of the samples with XRD, probably due to relatively low crystalline concentrations.

The XRD analysis results are given in Table 4.13. This table lists approximate amounts of crystals identified. A total crystalline content of roughly 15 to $20 \mathrm{wt} \%$ was estimated by the analysis to be in the glass samples.

\section{Glass Chemical Durability}

Table 4.14 lists the normalized elemental mass releases of $\mathrm{B}, \mathrm{Cs}, \mathrm{Na}$, $\mathrm{Si}$, Th, U, and those elements whose oxide contributed at least $1 \mathrm{wt} \%$ of the glass composition. Each value given represents the average obtained from three replicate tests. Normalized elemental mass releases of DG-WVIIR and DG-WV14R are given in Table 4.13 also for comparison. DG-WV11R may be treated as a control glass as its redox state is fairly close to that of the heat-treated glasses.

TABLE 4.13. Amounts (of Crystals Identified by XRD in Heat-Treated

\begin{tabular}{|c|c|c|c|}
\hline Sample ${ }^{(b)}$ & $\%$ Spinel (c) & \%Hematite $(d)$ & \%Fluorite (e) \\
\hline HT-S-3 & 12.00 & $<0.75$ & 3.00 \\
\hline HT-S-4 & 12.00 & 1.50 & 1.50 \\
\hline HT-S-2 & 13.50 & $<0.75$ & 1.50 \\
\hline HT -S-5 & 12.75 & $<0.75$ & 1.50 \\
\hline HT $-S-6$ & 14.24 & $<0.75$ & 0.74 \\
\hline HT $-S-1$ & 6.00 & 6.00 & 3.00 \\
\hline
\end{tabular}

(a) Based on total crystalline content of $15.0 \mathrm{wt} \%$.

(b) Ordered from fastest to slowest overall cooling rates.

(c) $(\mathrm{Fe}, \mathrm{Ni})(\mathrm{Cr}, \mathrm{Fe})_{2} \mathrm{O}_{4}$

(d) $(\mathrm{Cr}, \mathrm{Fe})_{2} \mathrm{O}_{3}$, less than values based on 5 wt\% detection

(e) $\mathrm{ThO}_{2}$ 
IABLE 4.14. Average Normalized Elemental Mass Releases of Glasses Heat-Treated with Simulated Canister Cooling Rates (7-Day, MCC-3, $90^{\circ} \mathrm{C}$, Deaerated DIW), $\mathrm{g} / \mathrm{m}^{2}$

\section{Glass Code}

$\begin{array}{lcccccccc}\text { Element } & \text { HT-S-1 } & \text { HT-S-2 } & \text { HT-S-3 } & \text { HT-S-4 } & \text { HT-S-5 } & \text { HT-S-6 } & \text { DG-WV11R } & \text { DG-WV14R } \\ \text { A1 } & 0.144 & 0.131 & 0.121 & 0.114 & 0.148 & 0.142 & 0.119 & 0.121 \\ \text { B } & 0.246 & 0.204 & 0.192 & 0.175 & 0.228 & 0.218 & 0.212 & 0.237 \\ \text { CS } & 0.113 & 0.123 & 0.119 & 0.158 & 0.133 & 0.132 & 0.092 & 0.067 \\ \text { Fe } & 0.005 & 0.003 & 0.002 & 0.002 & 0.005 & 0.005 & 0.003 & 0.003 \\ \text { K } & 0.132 & 0.121 & 0.097 & 0.125 & 0.116 & 0.164 & 0.020 & 0.095 \\ \text { Li } & 1.030 & 0.581 & 0.408 & 0.295 & 1.000 & 0.930 & 0.274 & 0.295 \\ \text { Mg } & 0.025 & 0.015 & 0.007 & 0.006 & 0.022 & 0.023 & 0.000 & 0.003 \\ \text { Mn } & 0.009 & 0.004 & 0.003 & 0.002 & 0.006 & 0.005 & 0.002 & 0.003 \\ \text { Na } & 0.265 & 0.217 & 0.206 & 0.188 & 0.249 & 0.237 & 0.209 & 0.249 \\ \text { P } & 1.472 & 0.749 & 0.461 & 0.294 & 1.450 & 1.329 & 0.177 & 0.182 \\ \text { Si } & 0.142 & 0.124 & 0.117 & 0.109 & 0.141 & 0.136 & 0.116 & 0.121 \\ \text { Th } & 0.009 & 0.004 & 0.003 & 0.003 & 0.007 & 0.007 & 0.000 & 0.000 \\ \text { Ti } & 0.007 & 0.004 & 0.003 & 0.002 & 0.007 & 0.007 & 0.001 & 0.001 \\ \text { U } & 0.062 & 0.045 & 0.039 & 0.048 & 0.070 & 0.073 & 0.024 & 0.025 \\ \text { pH (a) } & 10.14 & 9.89 & 9.81 & 9.77 & 10.20 & 10.14 & 9.64 & 9.91\end{array}$

(a) $\mathrm{pH}$ measured at test termination at $25^{\circ} \mathrm{C}$.

A graphical representation of $B$ and $S i$ releases for the heat-treated glasses is given in Figure 4.17. The error bars represent \pm two sds. The sds are based on replicate tests performed at the same time and do not include the time-related component of variability. The figure demonstrates that the heat treatments have a slight effect on the chemical durability of the glass. A maximum decrease of $15 \%$, based on $B$ release, over that of the reference glass is shown. Furthermore, Figure 4.17 shows the average normalized mass releases of $B$ and $S i$ from the heat-treated samples and DG-V11R and DG-WV14R. The DG-WV11R may be treated as a control glass as its redox state is fairly close to that of the heat-treated glasses. Statistical analyses of variance methods were used to compare the six heat-treated glasses (Specimens HT-S-1 through HT-6-S) with each other and with DG-WV1IR and DG-WV14R. The B and $\mathrm{Si}$ releases for the more quickly cooled specimens (HT-S-2, -3 , and -4 ) 


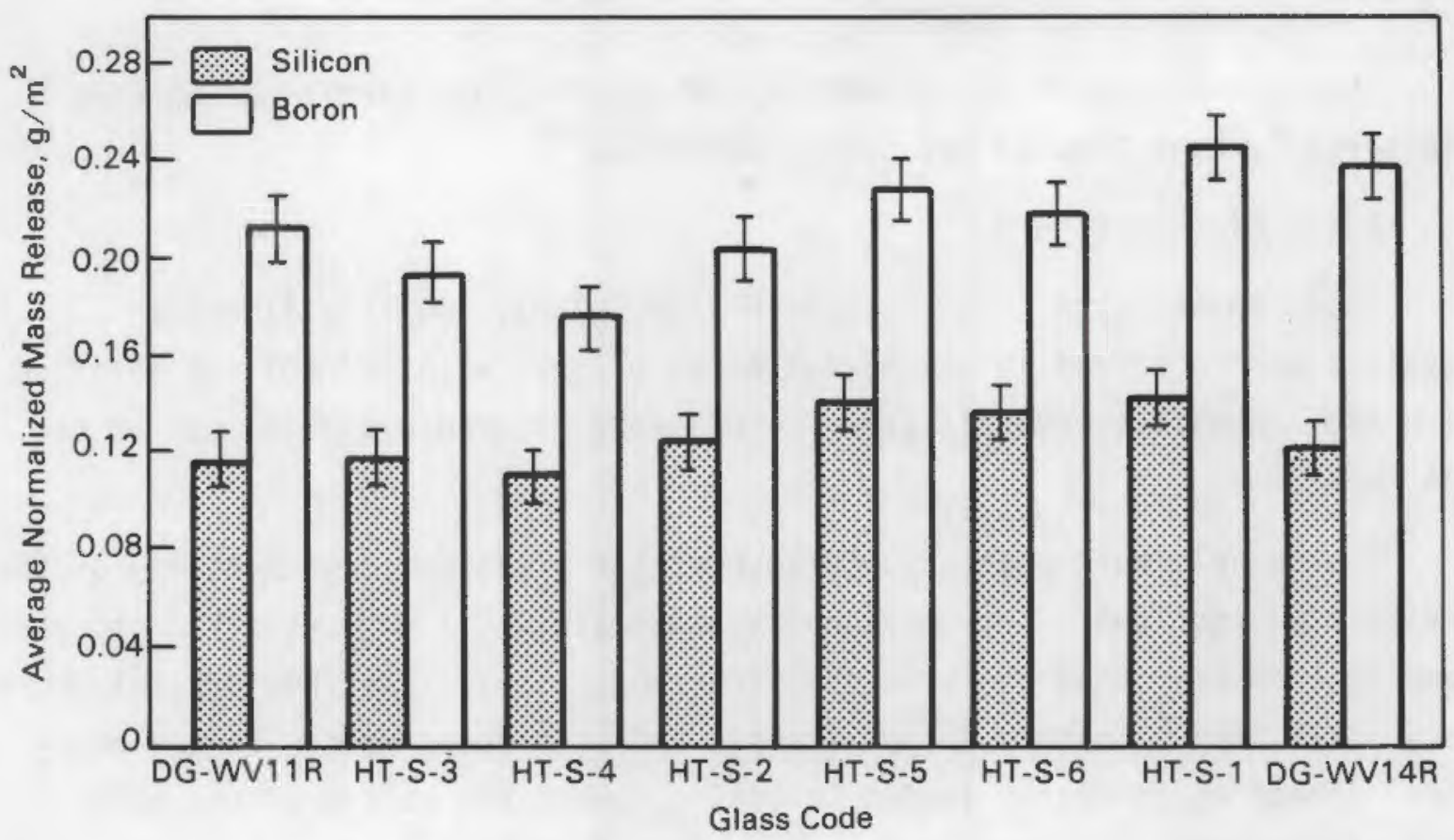

FIGURE 4.17. Comparison of Si and B Normalized Mass Releases from Slow-Cool Heat-Treated Glasses. (Heat-treated glasses are arranged in order from fastest to slowest relative cooling rates. Modified MCC-3 test, $90^{\circ} \mathrm{C}$, deaerated deionized water, 7-day.)

differ significantly from the releases for the more slowly cooled specimens (HT-S-1, -5, and -6 ), but the releases within these two groups do not differ significantly.

The $B$ and Si releases of DG-WVIIR are not significantly different from those for the quickly cooled glasses, indicating that this cooling does not affect chemical durability any more than slight glass reduction does. The $B$ releases of DG-WV14R and the more slowly cooled glasses are similar, which indicates that their chemical durabilities also are not significantly different.

The observed microstructure provides no further insight into the effect of the slow cooling treatments on chemical durability. There appears to be no correlation between type and amount of crystalline formation and chemical durability or heat treatment. 


\subsubsection{Isothermal Heat Treatment}

The microstructure and durability of the $15 \mathrm{glass}$ samples which were isothermally heat treated are described below.

\section{Glass Microstructure}

Cubic spinel-type crystals $\left[(\mathrm{Fe}, \mathrm{Ni})(\mathrm{Cr}, \mathrm{Fe})_{2} \mathrm{O}_{4}\right]$ and $\mathrm{ThO}_{2}$ fluorite crystals were observed in all heat-treated glasses with SEM/EDX and verified with XRD. Hematite crystals $\left[(\mathrm{Cr}, \mathrm{Fe})_{2} \mathrm{O}_{3}\right]$ were also observed in most of the specimens.

The spinels were scattered throughout the glass and some settling of the crystals was noticed. They measured approximately $0.3 \mu \mathrm{m}$ across--an order of magnitude smaller than the slow-cool treated glasses. The $\mathrm{ThO}_{2}$ crystals were very small, approximately $0.1 \mu \mathrm{m}$ across, and were found mainly in agglomerates. These agglomerates tended to settle toward the bottom of the melt. Most of the hematite crystals measured approximately $1.0 \mu \mathrm{m}$ across and appeared in greater amounts at temperatures greater than or equal to $725^{\circ} \mathrm{C}$ and holding times greater than 12 hours.

The glasses treated at $725^{\circ} \mathrm{C}$ for greater than or equal to 12 hours also contained a P-rich phase, possibly $\mathrm{Li}_{3} \mathrm{PO}_{4}$, and a separate calcium phosphate phase $\left(\mathrm{Ca}_{3}\left(\mathrm{PO}_{4}\right)_{2}\right)$, in addition to the crystalline phases described above. The amount of these phases increased with holding time.

The XRD analysis results are given in Table 4.15. This table lists approximate amounts of crystals identified by XRD, by wt\% relative to the standard (HT-S-22). The types of crystals listed are spinel, hematite, and fluorite (contains $\mathrm{ThO}_{2}$ ). The approximate amounts of spinel, hematite, and fluorite crystals in the standard are $7,0.3$, and $1.5 \mathrm{wt} \%$ respectively. The amounts of the crystals relative to the standard were obtained by ratioing specimen peak intensities to those of the standard. Therefore a value over one in Table 4.15 indicates the presence of a greater total amount, by weight, of that crystal than found in the standard and conversely, a value less than one indicates a lesser amount. A value of one indicates that the same $w t \%$ of the particular crystal is present in the specimen and the standard. 
TABLE 4.15. Amounts of Crystals Identified by XRD in Heat Treated G1asses Relative to Amounts in Standard Specimen (HT-S-22)(a)

\begin{tabular}{|c|c|c|c|c|}
\hline Sample & Temp/Time (b) & Spinel (c) & Hematite (d) & Fluorite (e) \\
\hline HT-S-22 & $500^{\circ} \mathrm{C} / 2 \mathrm{~h}$ & 1.0 & 1.0 & 1.0 \\
\hline $\begin{array}{l}\text { HT-S-7 } \\
\text { HT-S-8 }\end{array}$ & $\begin{array}{l}500^{\circ} \mathrm{C} / 120 \mathrm{~h} \\
500^{\circ} \mathrm{C} / 240 \mathrm{~h}\end{array}$ & $\begin{array}{l}0.48 \\
0.70\end{array}$ & $\begin{array}{l}1.01 \\
0.0\end{array}$ & $\begin{array}{l}0.13 \\
0.26\end{array}$ \\
\hline $\begin{array}{l}\text { HT }-S-9 \\
\text { HT-S-10 } \\
\text { HT-S-11 }\end{array}$ & $\begin{array}{l}600^{\circ} \mathrm{C} / 12 \mathrm{~h} \\
600^{\circ} \mathrm{C} / 48 \mathrm{~h} \\
600^{\circ} \mathrm{C} / 240 \mathrm{~h}\end{array}$ & $\begin{array}{l}0.91 \\
1.10 \\
0.88\end{array}$ & $\begin{array}{l}0.77 \\
0.0 \\
0.98\end{array}$ & $\begin{array}{l}0.29 \\
0.34 \\
0.36\end{array}$ \\
\hline $\begin{array}{l}\text { HT-S-12 } \\
\text { HT-S-13 } \\
\text { HT-S-14 } \\
\text { HT-S-15 } \\
\text { HT-S-16 }\end{array}$ & $\begin{array}{l}725^{\circ} \mathrm{C} / 6 \mathrm{~h} \\
725^{\circ} \mathrm{C} / 12 \mathrm{~h} \\
725^{\circ} \mathrm{C} / 48 \mathrm{~h} \\
725^{\circ} \mathrm{C} / 120 \mathrm{~h} \\
725^{\circ} \mathrm{C} / 240 \mathrm{~h}\end{array}$ & $\begin{array}{l}1.25 \\
0.99 \\
1.26 \\
1.03 \\
0.79\end{array}$ & $\begin{array}{l}0.0 \\
0.79 \\
2.26 \\
2.18 \\
2.80\end{array}$ & $\begin{array}{l}0.32 \\
0.61 \\
1.15 \\
0.80 \\
1.24\end{array}$ \\
\hline $\begin{array}{l}\text { HT-S-17 } \\
\text { HT-S-18 } \\
\text { HT-S-19 }\end{array}$ & $\begin{array}{l}800^{\circ} \mathrm{C} / 12 \mathrm{~h} \\
800^{\circ} \mathrm{C} / 48 \mathrm{~h} \\
800^{\circ} \mathrm{C} / 240 \mathrm{~h}\end{array}$ & $\begin{array}{l}0.97 \\
0.79 \\
0.41\end{array}$ & $\begin{array}{l}0.0 \\
5.66 \\
4.77\end{array}$ & $\begin{array}{l}1.04 \\
0.74 \\
0.81\end{array}$ \\
\hline $\begin{array}{l}\text { HT-S-20 } \\
\text { HT-S-21 }\end{array}$ & $\begin{array}{l}900^{\circ} \mathrm{C} / 120 \mathrm{~h} \\
900^{\circ} \mathrm{C} / 240 \mathrm{~h}\end{array}$ & $\begin{array}{l}0.39 \\
0.41\end{array}$ & $\begin{array}{l}2.54 \\
2.93\end{array}$ & $\begin{array}{l}1.13 \\
1.49\end{array}$ \\
\hline
\end{tabular}

(a) Relative amounts = (amount in glass, wt\%)/(amount in HT-S-22, wt\%)

(b) Temperature and holding time of heat treatment.

(c) $(\mathrm{Fe}, \mathrm{Ni})(\mathrm{Cr}, \mathrm{Fe})_{2} \mathrm{O}_{4} ;$ Approximately $7 \mathrm{wt} \%$ in $\mathrm{HT}-\mathrm{S}-22$.

(d) $(\mathrm{Cr}, \mathrm{Fe})_{2} \mathrm{O}_{3} ;$ Approximately $0.3 \mathrm{wt} \%$ in $\mathrm{HT}-\mathrm{S}-22$.

(e) $\mathrm{ThO}_{2}$; Approximately $1.5 \mathrm{wt} \%$ in $\mathrm{HT}-\mathrm{S}-22$.

Table 4.15 shows that, at temperatures of greater than or equal to $725^{\circ} \mathrm{C}$ and holding times of $48 \mathrm{~h}$ or more, hematite crystals are formed to a greater extent than in the standard as observed with SEM/EDX. Treatment temperatures less than $725^{\circ} \mathrm{C}$ appear to either have little effect on the glass crystallinity. The relative amount of fluorite is low and the presence of hematite is not detected in two of the specimens. The relative amount of spinel is less than that of the standard in the $500^{\circ} \mathrm{C}$ treated specimens.

\section{Glass Chemical Durability}

Tables $4.16,4.17$, and 4.18 list the normalized elemental mass releases of $\mathrm{B}, \mathrm{Na}, \mathrm{Si}$, Th, $\mathrm{U}$, and those elements whose oxide contributed at least 
TABLE 4.16. Average Normalized Mass Releases of Specimens Isothermally Treatęd at 500 and $600^{\circ} \mathrm{C}$ (7-day MCC-3, $90^{\circ} \mathrm{C}$, Deaerated DIW) $-\mathrm{g} / \mathrm{m}^{2}$

\begin{tabular}{|c|c|c|c|c|c|c|}
\hline Element & $\begin{array}{c}\mathrm{HT}-\mathrm{S}-22(\mathrm{a}) \\
500^{\circ} \mathrm{C} \\
2 \mathrm{~h} \\
\end{array}$ & $\begin{array}{r}\mathrm{HT}-\mathrm{S}-7 \\
500^{\circ} \mathrm{C} \\
120 \mathrm{~h} \\
\end{array}$ & $\begin{array}{r}H T-S-8 \\
500^{\circ} \mathrm{C} \\
240 \mathrm{~h} \\
\end{array}$ & $\begin{array}{r}\mathrm{HT}-\mathrm{S}-9 \\
600^{\circ} \mathrm{C} \\
12 \mathrm{~h} \\
\end{array}$ & $\begin{array}{l}\mathrm{HT}-\mathrm{S}-10 \\
600^{\circ} \mathrm{C} \\
48 \mathrm{~h} \\
\end{array}$ & $\begin{array}{c}\mathrm{HT}-\mathrm{S}-11 \\
600^{\circ} \mathrm{C} \\
240 \mathrm{~h} \\
\end{array}$ \\
\hline $\begin{array}{l}\mathrm{A} 1 \\
\mathrm{~B} \\
\mathrm{Fe}\end{array}$ & $\begin{array}{l}0.108 \\
0.182 \\
0.002\end{array}$ & $\begin{array}{l}0.110 \\
0.190 \\
0.003\end{array}$ & $\begin{array}{l}0.110 \\
0.187 \\
0.002\end{array}$ & $\begin{array}{l}0.113 \\
0.198 \\
0.002\end{array}$ & $\begin{array}{l}0.120 \\
0.212 \\
0.003\end{array}$ & $\begin{array}{l}0.154 \\
0.364 \\
0.008\end{array}$ \\
\hline $\begin{array}{l}\mathrm{K} \\
\mathrm{Li} \\
\mathrm{Mg}\end{array}$ & $\begin{array}{l}0.087 \\
0.219 \\
0.003\end{array}$ & $\begin{array}{l}0.120 \\
0.250 \\
0.005\end{array}$ & $\begin{array}{l}0.110 \\
0.241 \\
0.005\end{array}$ & $\begin{array}{l}0.109 \\
0.293 \\
0.012\end{array}$ & $\begin{array}{l}0.128 \\
0.367 \\
0.017\end{array}$ & $\begin{array}{l}0.133 \\
0.783 \\
0.013\end{array}$ \\
\hline $\begin{array}{l}\mathrm{Mn} \\
\mathrm{Na} \\
\mathrm{P}\end{array}$ & $\begin{array}{l}0.002 \\
0.186 \\
0.151\end{array}$ & $\begin{array}{l}0.002 \\
0.183 \\
0.182\end{array}$ & $\begin{array}{l}0.002 \\
0.172 \\
0.182\end{array}$ & $\begin{array}{l}0.003 \\
0.192 \\
0.312\end{array}$ & $\begin{array}{l}0.006 \\
0.211 \\
0.441\end{array}$ & $\begin{array}{l}0.021 \\
0.286 \\
1.147\end{array}$ \\
\hline $\begin{array}{l}\text { Si } \\
\text { Th } \\
\text { Ti } \\
U\end{array}$ & $\begin{array}{l}0.120 \\
0.001 \\
0.002 \\
0.031\end{array}$ & $\begin{array}{l}0.119 \\
0.002 \\
0.002 \\
0.034\end{array}$ & $\begin{array}{l}0.119 \\
0.002 \\
0.002 \\
0.032\end{array}$ & $\begin{array}{l}0.126 \\
0.002 \\
0.003 \\
0.039\end{array}$ & $\begin{array}{l}0.131 \\
0.004 \\
0.005 \\
0.051\end{array}$ & $\begin{array}{l}0.145 \\
0.032 \\
0.021 \\
0.123\end{array}$ \\
\hline $\mathrm{pH}^{(\mathrm{b})}$ & 9.22 & 9.18 & 9.21 & 9.39 & 9.42 & 9.36 \\
\hline
\end{tabular}

(a) Prepared standard.

(b) $\mathrm{pH}$ measured at test termination at $25^{\circ} \mathrm{C}$.

$1 \mathrm{wt} \%$ of the glass composition. Each value given represents the average obtained from three replicate tests. The three replicate tests were performed at the same time under the same conditions, and the resulting leachates were chemically analyzed at the same time under the same conditions. Hence, the replicates only include short-term variations in the leach testing and leachate analysis processes.

Figure 4.18 shows the $B$ release data for the isothermally heat-treated glasses plotted as a function of heat treatment time and treatment temperature on a time-temperature-transformation diagram. The $B$ release values for each sample are shown, as well as the approximate locations of a series of constant leaching isopleths. 
TABLE 4.17. Average Normalized Mass Releases of Specimens Isothermally Treated at $725^{\circ} \mathrm{C}$ (7-day MCC $-3,90^{\circ} \mathrm{C}$, Deaerated DIW), $\mathrm{g} / \mathrm{m}^{2}$

\begin{tabular}{|c|c|c|c|c|c|c|}
\hline Element & $\begin{array}{c}\mathrm{HT}-\mathrm{S}-22(\mathrm{a}) \\
500^{\circ} \mathrm{C} \\
2 \mathrm{~h} \\
\end{array}$ & $\begin{array}{c}\text { Glass Co } \\
\mathrm{HT}-\mathrm{S}-12 \\
725^{\circ} \mathrm{C} \\
120 \mathrm{~h} \\
\end{array}$ & $\begin{array}{c}\text { Treatme } \\
\text { HT-S-13 } \\
725^{\circ} \mathrm{C} \\
240 \mathrm{~h} \\
\end{array}$ & $\begin{array}{c}\mathrm{t} \text { Temper: } \\
\mathrm{HT}-\mathrm{S}-14 \\
725^{\circ} \mathrm{C} \\
12 \mathrm{~h} \\
\end{array}$ & $\begin{array}{c}\mathrm{re}, \text { and } \\
\mathrm{HT}-\mathrm{S}-15 \\
725^{\circ} \mathrm{C} \\
48 \mathrm{~h} \\
\end{array}$ & $\begin{array}{c}\text { ding Tim } \\
\text { HT-S-16 } \\
725^{\circ} \mathrm{C} \\
240 \mathrm{~h} \\
\end{array}$ \\
\hline $\begin{array}{l}\mathrm{Al} \\
\mathrm{B} \\
\mathrm{Fe}\end{array}$ & $\begin{array}{l}0.108 \\
0.182 \\
0.002\end{array}$ & $\begin{array}{l}0.124 \\
0.212 \\
0.004\end{array}$ & $\begin{array}{l}0.155 \\
0.261 \\
0.011\end{array}$ & $\begin{array}{l}0.159 \\
0.262 \\
0.014\end{array}$ & $\begin{array}{l}0.160 \\
0.262 \\
0.014\end{array}$ & $\begin{array}{l}0.160 \\
0.263 \\
0.014\end{array}$ \\
\hline $\begin{array}{l}\mathrm{K} \\
\mathrm{Li} \\
\mathrm{Mg}\end{array}$ & $\begin{array}{l}0.087 \\
0.219 \\
0.003\end{array}$ & $\begin{array}{l}0.109 \\
0.582 \\
0.019\end{array}$ & $\begin{array}{l}0.154 \\
1.500 \\
0.035\end{array}$ & $\begin{array}{l}0.176 \\
1.545 \\
0.039\end{array}$ & $\begin{array}{l}0.153 \\
1.515 \\
0.040\end{array}$ & $\begin{array}{l}0.161 \\
1.543 \\
0.039\end{array}$ \\
\hline $\begin{array}{l}\mathrm{Mn} \\
\mathrm{Na} \\
\mathrm{P}\end{array}$ & $\begin{array}{l}0.002 \\
0.186 \\
0.151\end{array}$ & $\begin{array}{l}0.005 \\
0.205 \\
0.791\end{array}$ & $\begin{array}{l}0.014 \\
0.270 \\
2.377\end{array}$ & $\begin{array}{l}0.017 \\
0.267 \\
2.472\end{array}$ & $\begin{array}{l}0.017 \\
0.263 \\
2.309\end{array}$ & $\begin{array}{l}0.018 \\
0.272 \\
2.377\end{array}$ \\
\hline $\begin{array}{l}\text { Si } \\
\text { Th } \\
\text { Ti } \\
\text { U }\end{array}$ & $\begin{array}{l}0.120 \\
0.001 \\
0.002 \\
0.031\end{array}$ & $\begin{array}{l}0.138 \\
0.003 \\
0.004 \\
0.046\end{array}$ & $\begin{array}{l}0.169 \\
0.009 \\
0.020 \\
0.088\end{array}$ & $\begin{array}{l}0.172 \\
0.011 \\
0.026 \\
0.110\end{array}$ & $\begin{array}{l}0.170 \\
0.016 \\
0.028 \\
0.113\end{array}$ & $\begin{array}{l}0.171 \\
0.017 \\
0.025 \\
0.096\end{array}$ \\
\hline $\mathrm{pH}^{(\mathrm{b})}$ & 9.22 & 9.47 & 10.08 & 10.02 & 9.94 & 9.92 \\
\hline
\end{tabular}

(a) Prepared standard.

(b) $\mathrm{pH}$ measured at test termination at $25^{\circ} \mathrm{C}$.

The appearance of this diagram is essentially identical to what would be expected if crystallinity were plotted instead of chemical durability. This similarity is not surprising because devitrification of (growth of crystallinity in) the glass causes the decrease in durability. A maximum decrease in durability by a factor of two was found for the isothermally heat-treated samples $\left(500^{\circ} \mathrm{C}\right.$ for $2 \mathrm{~h}$ versus $600^{\circ} \mathrm{C}$ for $\left.240 \mathrm{~h}\right)$. This type of behavior for a similar glass, SRL-165, was found in another study (Jantzen, Bickford, and Karraker 1984). In that study, the decrease in glass durability was attributed to the formation of acmite, $\mathrm{NaFeSi}_{2} \mathrm{O}_{6}$, as one of the devitrification products. 
TABLE 4.18. Average Normalized Mass Releases of Specimens Isothermally Treated at $800^{\circ} \mathrm{C}$ and $900^{\circ} \mathrm{C}$ (7-day $\mathrm{MCC}-3,90^{\circ} \mathrm{C}$, Deaerated DIW), $\mathrm{g} / \mathrm{m}^{2}$

\begin{tabular}{|c|c|c|c|c|c|c|}
\hline Element & $\begin{array}{c}\text { HT }-\mathrm{S}-22(\mathrm{a}) \\
500^{\circ} \mathrm{C} \\
2 \mathrm{~h} \\
\end{array}$ & $\begin{array}{c}\text { Glass Co } \\
\text { HT-S-17 } \\
800^{\circ} \mathrm{C} \\
120 \mathrm{~h} \\
\end{array}$ & $\begin{array}{c}\text { Treatme } \\
\text { HT-S-18 } \\
800^{\circ} \mathrm{C} \\
240 \mathrm{~h} \\
\end{array}$ & $\begin{array}{c}\text { Tempera } \\
\text { HT-S-19 } \\
800^{\circ} \mathrm{C} \\
12 \mathrm{~h} \\
\end{array}$ & $\begin{array}{c}\mathrm{e}, \text { and } \mathrm{Ho} \\
\mathrm{HT}-\mathrm{S}-20 \\
900^{\circ} \mathrm{C} \\
48 \mathrm{~h} \\
\end{array}$ & $\begin{array}{r}\text { ing Time } \\
\mathrm{HT}-\mathrm{S}-21 \\
900^{\circ} \mathrm{C} \\
240 \mathrm{~h} \\
\end{array}$ \\
\hline $\begin{array}{l}\mathrm{A} 1 \\
\mathrm{~B} \\
\mathrm{Fe}\end{array}$ & $\begin{array}{l}0.108 \\
0.182 \\
0.002\end{array}$ & $\begin{array}{l}0.141 \\
0.238 \\
0.010\end{array}$ & $\begin{array}{l}0.112 \\
0.186 \\
0.003\end{array}$ & $\begin{array}{l}0.124 \\
0.222 \\
0.004\end{array}$ & $\begin{array}{l}0.112 \\
0.203 \\
0.002\end{array}$ & $\begin{array}{l}0.112 \\
0.204 \\
0.002\end{array}$ \\
\hline $\begin{array}{l}\mathrm{K} \\
\mathrm{Li} \\
\mathrm{Mg}\end{array}$ & $\begin{array}{l}0.087 \\
0.219 \\
0.003\end{array}$ & $\begin{array}{l}0.145 \\
1.106 \\
0.032\end{array}$ & $\begin{array}{l}0.113 \\
0.267 \\
0.013\end{array}$ & $\begin{array}{l}0.026 \\
0.537 \\
0.009\end{array}$ & $\begin{array}{l}0.091 \\
0.253 \\
0.005\end{array}$ & $\begin{array}{l}0.102 \\
0.265 \\
0.007\end{array}$ \\
\hline $\begin{array}{l}\mathrm{Mn} \\
\mathrm{Na} \\
\mathrm{P}\end{array}$ & $\begin{array}{l}0.002 \\
0.186 \\
0.151\end{array}$ & $\begin{array}{l}0.011 \\
0.251 \\
1.657\end{array}$ & $\begin{array}{l}0.004 \\
0.187 \\
0.231\end{array}$ & $\begin{array}{l}0.005 \\
0.219 \\
0.643\end{array}$ & $\begin{array}{l}0.003 \\
0.186 \\
0.164\end{array}$ & $\begin{array}{l}0.003 \\
0.193 \\
0.172\end{array}$ \\
\hline $\begin{array}{l}\text { Si } \\
\text { Th } \\
\text { Ti }\end{array}$ & $\begin{array}{l}0.120 \\
0.001 \\
0.002 \\
0.031\end{array}$ & $\begin{array}{l}0.154 \\
0.007 \\
0.014 \\
0.070\end{array}$ & $\begin{array}{l}0.122 \\
0.001 \\
0.003 \\
0.034\end{array}$ & $\begin{array}{l}0.135 \\
0.002 \\
0.003 \\
0.045\end{array}$ & $\begin{array}{l}0.120 \\
0.001 \\
0.002 \\
0.031\end{array}$ & $\begin{array}{l}0.122 \\
0.001 \\
0.002 \\
0.033\end{array}$ \\
\hline $\mathrm{pH}^{(\mathrm{b})}$ & 9.22 & 9.87 & 9.26 & 9.40 & 9.22 & 9.42 \\
\hline
\end{tabular}

(a) Prepared standard.

(b) $\mathrm{pH}$ measured at test termination at $25^{\circ} \mathrm{C}$.

\subsection{GROUNDWATER EFFECTS}

Table 4.19 lists the normalized elemental mass releases of $\mathrm{B}, \mathrm{Cs}, \mathrm{Na}$, $\mathrm{Si}$, Th, U, and those elements whose oxide contributed at least $1 \mathrm{wt} \%$ of the glass composition. Calcium and $\mathrm{Mg}$ releases are not included because corrections of the leachate concentrations could not be made with the test blanks see above). Each value given represents the average obtained from three replicate tests. The average normalized mass releases of DG-WV11R are given in Table 4.19 to provide a comparison.

Graphical representation of $B$ and Si releases are given in Figure 4.19. The error bars represent \pm two sds. The sds are based on replicate tests performed at the same time and do not include the time-related component of variability. The releases of DG-WV11R are included in the figure to provide 


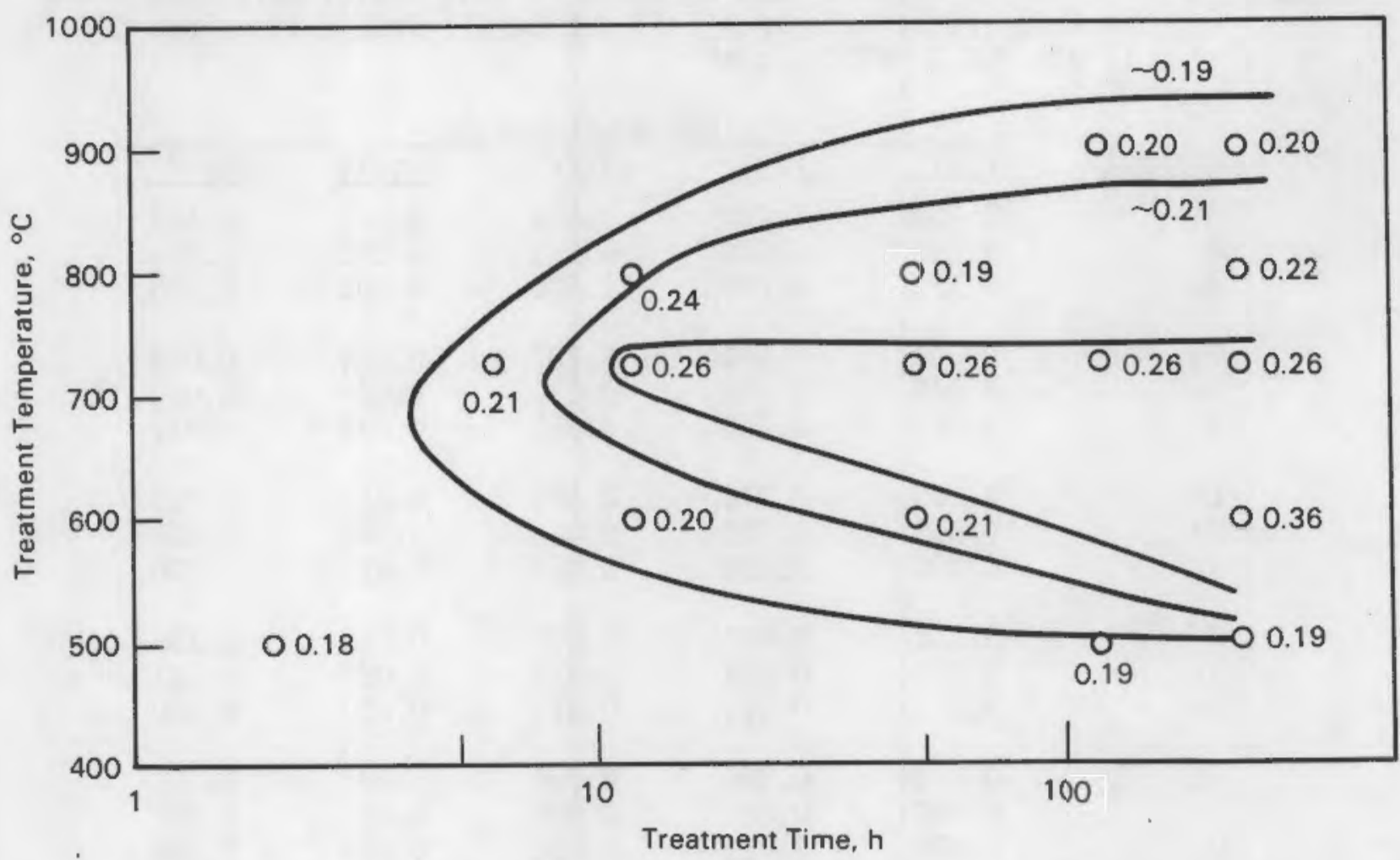

FIGURE 4.18. Time-Temperature-Transformation Diagram for B Releases from Isothermally Heat-Treated Reference Glass (WVCM-50). (Numbers in graph are B releases in $\mathrm{g} / \mathrm{m}^{2}$.) 7-day MCC-3, deaerated DIW, $90^{\circ} \mathrm{C}$.

a comparison between glass chemical durability in DIW versus groundwater. The tests were conducted under the exact same conditions except that the redox adjusted glass was leached under $\mathrm{CO}_{2}$-free conditions, while the groundwater leached glass was leached in a standard air atmosphere.

Figure 4.19 shows that groundwater type has a definite effect on the chemical durability of the glass and that the glass appears to be more chemically durable in the groundwaters tested than in deaerated DIW, under $\mathrm{CO}_{2}$-free conditions. Specifically, Figure 4.19 demonstrates that the glass is most chemically durable in PBBI and least chemically durable in DIW. The difference in durability, based on B release, is greater than in DIW by approximately a factor of 5 in PBB1, 4 in PBB3, 3 in $\mathrm{J}-13$ well water, and 2 in GR-4. 
TABLE 4.19. Average Normalized Mass Releases of West Valley Reference Glass in PBB1, PBB3, Reference Tuff and Basalt Groundwaters and DIW (7-day $\left.M C C-3,90^{\circ} \mathrm{C}\right), \mathrm{g} / \mathrm{m}^{2}$

\begin{tabular}{|c|c|c|c|c|c|}
\hline \multirow[b]{2}{*}{ Element } & \multicolumn{5}{|c|}{ Groundwater Type } \\
\hline & PBBI & PBB3 & Tuff & Basalt & DIW(a) \\
\hline $\begin{array}{l}\mathrm{A} 1 \\
\mathrm{~B} \\
\mathrm{Ba}\end{array}$ & $\begin{array}{l}0.000 \\
0.045 \\
0.127\end{array}$ & $\begin{array}{l}0.000 \\
0.060 \\
0.206\end{array}$ & $\begin{array}{l}0.014 \\
0.076 \\
0.000\end{array}$ & $\begin{array}{l}0.028 \\
0.092 \\
0.000\end{array}$ & $\begin{array}{l}0.113 \\
0.209 \\
0.000\end{array}$ \\
\hline $\begin{array}{l}\mathrm{Cs} \\
\mathrm{Fe} \\
\mathrm{K}\end{array}$ & $\begin{array}{l}0.000 \\
0.000 \\
0.252\end{array}$ & $\begin{array}{l}0.000 \\
0.000 \\
0.000\end{array}$ & $\begin{array}{l}0.107 \\
0.000 \\
0.055\end{array}$ & $\begin{array}{l}0.114 \\
0.009 \\
0.044\end{array}$ & $\begin{array}{l}0.069 \\
0.000 \\
0.017\end{array}$ \\
\hline $\begin{array}{l}\mathrm{Li} \\
\mathrm{Mn} \\
\mathrm{Na}\end{array}$ & $\begin{array}{l}0.205 \\
0.000 \\
0.000\end{array}$ & $\begin{array}{l}0.216 \\
0.000 \\
0.000\end{array}$ & $\begin{array}{l}0.191 \\
0.000 \\
0.094\end{array}$ & $\begin{array}{l}0.214 \\
0.008 \\
0.025\end{array}$ & $\begin{array}{l}0.259 \\
0.000 \\
0.200\end{array}$ \\
\hline $\begin{array}{l}\mathrm{P} \\
\mathrm{Si} \\
\mathrm{Sr}\end{array}$ & $\begin{array}{l}0.000 \\
0.010 \\
0.311\end{array}$ & $\begin{array}{l}0.000 \\
0.025 \\
0.000\end{array}$ & $\begin{array}{l}0.000 \\
0.015 \\
0.013\end{array}$ & $\begin{array}{l}0.058 \\
0.027 \\
0.000\end{array}$ & $\begin{array}{l}0.168 \\
0.111 \\
0.000\end{array}$ \\
\hline $\begin{array}{l}\text { Th } \\
\text { Ti } \\
\text { U }\end{array}$ & $\begin{array}{l}0.000 \\
0.000 \\
0.006\end{array}$ & $\begin{array}{l}0.000 \\
0.000 \\
0.022\end{array}$ & $\begin{array}{l}0.000 \\
0.000 \\
0.032\end{array}$ & $\begin{array}{l}0.001 \\
0.002 \\
0.045\end{array}$ & $\begin{array}{l}0.000 \\
0.000 \\
0.019\end{array}$ \\
\hline $\mathrm{pH}$ (b) & 8.25 & 6.47 & 8.85 & 9.84 & 9.91 \\
\hline
\end{tabular}
(a) Normalized mass release of DG-WVIlR glass, slightly redox adjusted glass, leached in deaerated water, $\mathrm{CO}_{2}$-free conditions.

(b) $\mathrm{pH}$ measured at test termination at $25^{\circ} \mathrm{C}$.

That the brines, PBB1 and PBB3, caused the lowest amount of leaching is consistent with a known decreased solubility of $\mathrm{SiO}_{2}$-bearing solids in solutions of high ionic strength. The relative saturation fraction of silicic acid in the leachant plays an important role in determining the glass reactivity (Strachan, Pederson, and Lokken 1985). This explains why the groundwater (composition close to that of GR-4), and to a smaller extent in brine at $90^{\circ} \mathrm{C}$. The glass was found to leach more readily in DIW than the synthetic groundwater at $40^{\circ} \mathrm{C}$. The results reported here also agree with this outcome. 


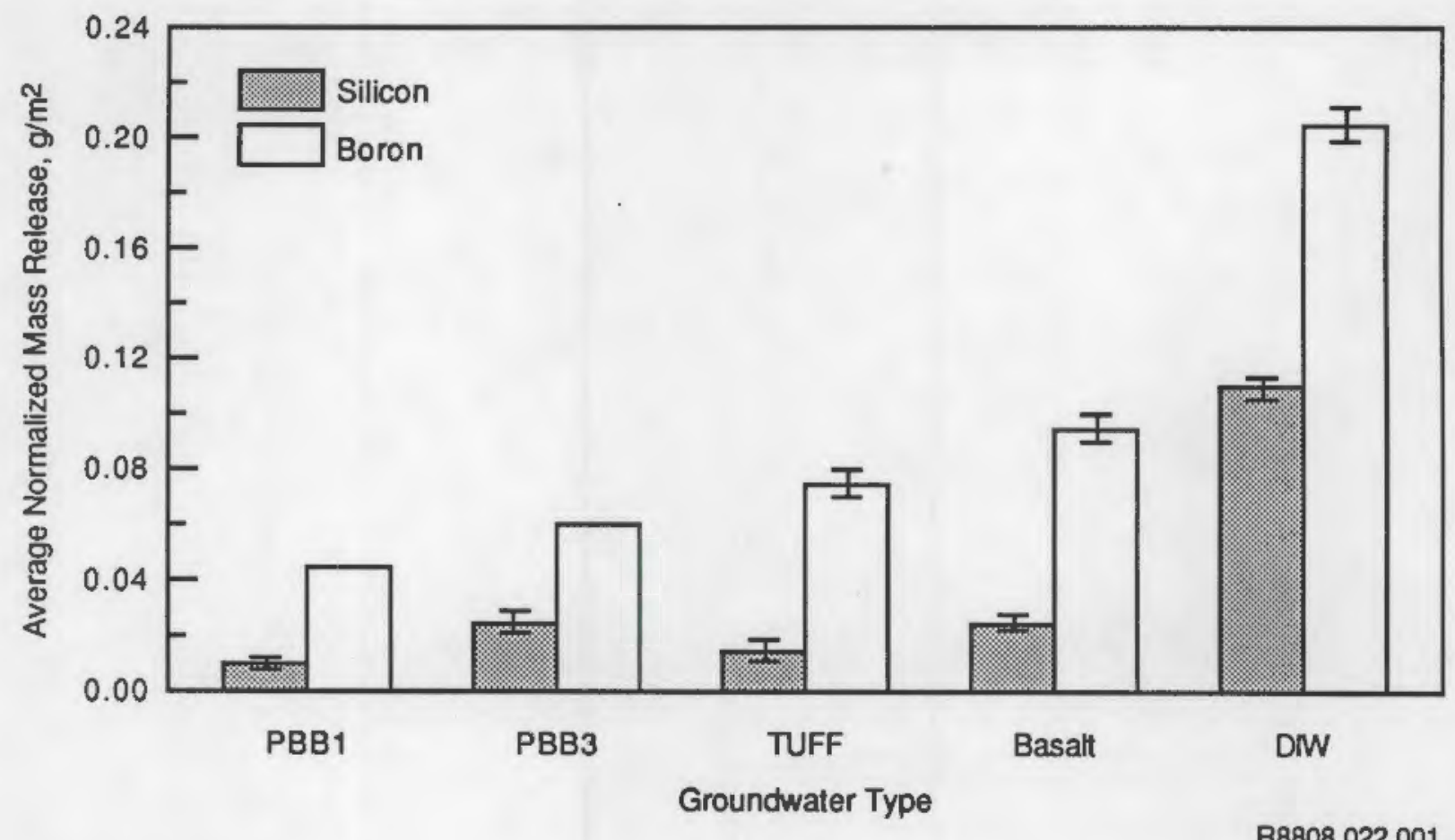

FIGURE 4.19. Comparison of B and Si Normalized Mass Releases from Reference G1 ass in Different Groundwaters (7-day MCC-3, deaerated DIW, $\left.90^{\circ} \mathrm{C}\right)$

Figure 4.19 also demonstrates that glass dissolution is greater in PBB3 than PBBI and that dissolution is greater in basalt groundwater than in tuff groundwater. The brine-caused durability difference agrees with results found in the literature. The major difference between the brine compositions is $\mathrm{Mg}$ concentration, which is higher in PBB3. Early leaching studies conducted in brine solutions (Braithwaite 1980) concluded that glass dissolution increases with an increasing $\mathrm{Mg}$ content in the brine. The researchers attributed this effect to $\mathrm{Mg}$ causing a decrease in $\mathrm{pH}$ and substituting for divalent oxides 1 ike $\mathrm{CaO}$ and $\mathrm{SrO}$ in the glass matrix. However, other brine leaching studies (McGrail and Reimus 1987) have shown that the kinetics of dissolution of a defense waste glass were not affected by the difference in brine composition. The difference in durability observed between basalt and tuff groundwater is most probably caused by the higher initial $\mathrm{pH}$ of the basalt groundwater (10.18 versus 8.20$)$ allowing for greater glass network attack. 



\subsection{REFERENCES}

Braithwaite, J. W. 1980. "Brine Chemistry Effects on the Durability of a Simulated Waste Glass." Sci. Basis Nuc. Waste Manag. 2:199, ed. C. J .M. Northrup, Plenum Press, New York.

Corne11, J. A. 1981. Experiments With Mixtures: Designs, Models, and the Analysis of Mixture Data, John Wiley and Sons, New York.

Dill, J. A., et al. 1985. An Evaluation of the Stability of Synthetic Groundwater Formulations GR-3 and GR-4. SD-BWI-TD-013, Rev. 0, Rockwe11 Hanford Operations, Richland, Washington.

Jantzen, C. M., D. F. Bickford, and D. G. Karraker. 1984. "Time-

Temperature-Transformation Kinetics in SRL Waste Glass." In Nuclear Waste Management. Advances in Ceramics. Vol. 8, eds. G. C. Wicks and W. A. Ross, pp. 30-38, American Ceramic Society, Columbus, Ohio.

Materials Characterization Center (MCC). 1986. Test Methods Submitted for Nuclear Waste Materials Handbook. PNL-3990, Pacific Northwest Laboratory, Richland, Washington.

McGrail, B. P. and M. A. Reimus. 1987. Salt Repository Project - Glass Studies Program: FY 1986 Annual Report. PNL/SRP-6389, Pacific Northwest Laboratory, Richland, Washington.

Miller, R. G., Jr. 1981. Simultaneous Statistical Interference. 2nd Edition, Springer-Verlag, New York.

Montgomery, D. C. 1976. Design and Analysis of Experiments, John Wiley and Sons, New York, New York.

Oversby, V. M. 1985. The Reaction of Topopah Spring Tuff with $\mathrm{J}-13$ Water at $150^{\circ} \mathrm{C}$--Samples from Dril1 Cores USW G-1, USW GU-3, USH G-4, and UE-25h\# 1 . UCRL-53629, Lawrence Livermore National Laboratory, Livermore, California.

Piepe], G. F. 1982. "Measuring Component Effects in Constrained Mixture Experiments," Technometrics 24:29-39.

Piepel, G. F. 1988. "Programs for Generating Extreme Vertices and Centroids of Linearly Constrained Experimenta] Regions," Journal of Quality Technology, 20:125-139.

Snee, R. D. 1985. "Computer-Aided Oesign of Experiments - Some Practical Experiences," Journal of Ouality Technology, 17:222-236.

Strachan, 0. M., L. R. Pederson, and R. 0. Lokken. 1985. Results from the Long-Term Interaction and Modeling of SRL-131 Glass with Aqueous Solutions. PNL-5654, Pacific Northwest Laboratory, Richland, Washington. 


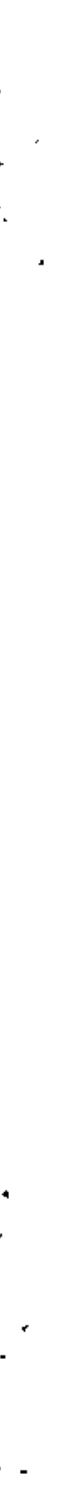


APPENDIX A

AVERAGE NORMALIZED MASS RELEASES OF DG-WVI 
APPENDIX A

\section{AVERAGE NORMALIZED MASS RELEASES OF DG-WYI}

TABLE A.1. DG-WV1 Average Normalized Mass Releases and Corresponding Uncertainties (7-day MCC-3, deaerated DIW, $90^{\circ} \mathrm{C}$ )

Normalized Mass Release, $\mathrm{g} / \mathrm{m}^{2}$ Test

\begin{tabular}{|c|c|c|c|c|c|c|}
\hline \multirow[b]{2}{*}{ Element } & & \multirow{2}{*}{$\begin{array}{l}\text { Standard } \\
\text { Deviation }(f)\end{array}$} & \multirow[b]{2}{*}{$\%$ RSD $^{(g)}$} \\
\hline & $A^{(a)}$ & ${ }_{B^{(b)}}^{(b)}$ & $c^{(c)}$ & $\mathrm{D}^{(\mathrm{d})}$ & & \\
\hline $\begin{array}{l}\mathrm{Al} \\
\mathrm{B} \\
\mathrm{Ba} \\
\mathrm{Ca} \\
\mathrm{Ce}\end{array}$ & $\begin{array}{l}0.106 \\
0.186 \\
0.000 \\
0.002 \\
0.000\end{array}$ & $\begin{array}{l}0.096 \\
0.148 \\
0.000 \\
0.002 \\
0.000\end{array}$ & $\begin{array}{l}0.103 \\
0.154 \\
0.000 \\
0.009 \\
0.000\end{array}$ & $\begin{array}{l}0.107 \\
0.177 \\
0.001 \\
0.005 \\
0.000\end{array}$ & $\begin{array}{c}4.94 \mathrm{E}-03 \\
1.80 \mathrm{E}-02 \\
\text { (h) } \\
3.40 \mathrm{E}-03 \\
0.00 \mathrm{E}+00\end{array}$ & $\begin{array}{c}4.8 \\
10.8 \\
(\mathrm{~h}) \\
76.4 \\
0.0\end{array}$ \\
\hline $\begin{array}{l}\mathrm{Cr} \\
\mathrm{Cs} \\
\mathrm{Fe} \\
\mathrm{K} \\
\mathrm{La}\end{array}$ & $\begin{array}{l}0.000 \\
0.104 \\
0.002 \\
0.021 \\
0.000\end{array}$ & $\begin{array}{l}0.000 \\
0.107 \\
0.002 \\
0.081 \\
0.000\end{array}$ & $\begin{array}{l}0.000 \\
0.073 \\
0.003 \\
0.082 \\
0.000\end{array}$ & $\begin{array}{l}0.000 \\
0.108 \\
0.003 \\
0.045 \\
0.000\end{array}$ & $\begin{array}{l}0.00 \mathrm{E}+00 \\
1.81 \mathrm{E}-02 \\
0.56 \mathrm{E}-03 \\
3.06 \mathrm{E}-02 \\
0.00 \mathrm{E}+00\end{array}$ & $\begin{array}{r}0.0 \\
18.3 \\
23.6 \\
53.5 \\
0.0\end{array}$ \\
\hline $\begin{array}{l}\mathrm{Li} \\
\mathrm{Mg} \\
\mathrm{Mn} \\
\mathrm{Mo} \\
\mathrm{Na}\end{array}$ & $\begin{array}{l}0.301 \\
0.000 \\
0.001 \\
0.181 \\
0.158\end{array}$ & $\begin{array}{l}0.221 \\
0.003 \\
0.001 \\
0.082 \\
0.134\end{array}$ & $\begin{array}{l}0.214 \\
0.007 \\
0.003 \\
0.149 \\
0.139\end{array}$ & $\begin{array}{l}0.263 \\
0.000 \\
0.002 \\
0.149 \\
0.156\end{array}$ & $\begin{array}{l}4.06 \mathrm{E}-02 \\
3.40 \mathrm{E}-02 \\
0.57 \mathrm{E}-03 \\
5.16 \mathrm{E}-02 \\
1.22 \mathrm{E}-02\end{array}$ & $\begin{array}{r}16.2 \\
142.6 \\
31.2 \\
36.5 \\
8.3\end{array}$ \\
\hline $\begin{array}{l}\text { P } \\
\text { Si } \\
\text { Sr } \\
\text { Th }\end{array}$ & $\begin{array}{l}0.105 \\
0.116 \\
0.000 \\
0.001\end{array}$ & $\begin{array}{l}0.063 \\
0.103 \\
0.000 \\
0.002\end{array}$ & $\begin{array}{l}0.055 \\
0.109 \\
0.000 \\
0.003\end{array}$ & $\begin{array}{l}0.088 \\
0.117 \\
0.000 \\
0.002\end{array}$ & $\begin{array}{l}2.32 \mathrm{E}-02 \\
6.58 \mathrm{E}-03 \\
0.00 \mathrm{E}+00 \\
0.83 \mathrm{E}-03\end{array}$ & $\begin{array}{r}29.9 \\
5.9 \\
0.0 \\
38.9\end{array}$ \\
\hline $\begin{array}{l}T i \\
U \\
Z r\end{array}$ & $\begin{array}{l}0.001 \\
0.026 \\
0.032\end{array}$ & $\begin{array}{l}0.001 \\
0.039 \\
0.002\end{array}$ & $\begin{array}{l}0.002 \\
0.038 \\
0.003\end{array}$ & $\begin{array}{l}0.002 \\
0.034 \\
0.003\end{array}$ & $\begin{array}{l}0.35 \mathrm{E}-03 \\
6.22 \mathrm{E}-03 \\
1.47 \mathrm{E}-02\end{array}$ & $\begin{array}{r}24.5 \\
18.0 \\
145.0\end{array}$ \\
\hline $\mathrm{pH}(e)$ & 9.15 & 9.22 & 8.42 & 9.38 & & \\
\hline
\end{tabular}

(a) Average of triplicate data, test run began 1-15-87.

(b) Average of triplicate data, test run began 4-13-87.

(c) Average of triplicate data, test run began 5-21-87.

(d) Average of triplicate data, test run began 6-3-87.

(e) $\mathrm{pH}$ at test termination at $25^{\circ} \mathrm{C}$.

(f) Combined short- and long-term variation in the leach testing and leachate analysis processes.

(g) The test standard deviation expressed as a percentage of the overall

(h) Not computed. 
' 
APPENDIX B

FORMULAS FOR CONFIDENCE AND TOLERANCE BANDS 
APPENDIX B

FORMULAS FOR CONFIDENCE AND TOLERANCE BANDS

Formulas for (1- $\alpha) 100 \%$ one-sided upper and two-sided confidence bands and $(1-\alpha) 100 \% /(1-\gamma) 100 \%$ one- and two-sided upper tolerance bands on a fitted (least squares) model are presented here.

In general, let the model be represented in vector notation by

$$
y=\underline{x}^{\prime} \underline{b}
$$

where $y=$ normalized boron release (NBR)

$\underline{b}=a p \times l$ column vector of estimated parameters

$\underline{x}^{\prime}=$ a $1 \times p$ row vector whose elements are functions of the oxide component proportions.

For the linear mixture models given by Equations (4), (5), (6), and (7) in this report, $\underline{x}$ is just the vector of the eleven oxide component weight fractions, and $p=11$.

Now let $\underset{\sim}{x}$ represent the $n \times p$ matrix of $\underset{\sim}{x}$ vectors for which we have data, where $n$ is the number of data points. The matrix $\underline{x}$ is sometimes referred to as the design or test matrix. Then, for the design matrix $\underset{\sim}{X}$, Eq. (B.1) can be written in the form

$$
\underline{y}=\underset{\sim}{x} \underset{\sim}{b}
$$

where $\underline{x}$ is an $n \times 1$ column vector containing the NBR value for each data point. The least squares estimate of the parameter vector is

$$
\hat{\underline{b}}=\left(\underline{x}^{\prime} \underline{\sim}\right)^{-1} \underline{x}^{\prime} \underline{y}
$$


and the predicted NBR at any composition $\underline{x}$ is given by

$$
\hat{y}(\underset{\sim}{x})=\underline{x}^{\prime} \underline{\underline{b}}
$$

The (1- $\alpha$ ) $100 \%$ one-sided upper and two-sided confidence bands on the fitted models are given by Equations (B.4) and (B.5) respectively,

$$
\begin{aligned}
& \hat{y}(x)+\sqrt{p F_{1-2 \alpha}(p, q) x^{\prime}\left(x^{\prime} x\right)^{-1} x \hat{\sigma}^{2}} \\
& \hat{y}(x) \pm \sqrt{p F_{1-\alpha}(p, q) x^{\prime}\left(x^{\prime} x\right)^{-1} \times \hat{\sigma}^{2}}
\end{aligned}
$$

where $\hat{y}(x)=$ the predicted value from the fitted model at composition $\underline{x}$ $\underline{x}=\mathbf{a} \times \mathbb{1}$ vector of oxide component weight fractions corresponding to any glass within the compositional region

$F_{1-2 \alpha}(p, q)=(1-2 \alpha) 100$ th percentile of the central F-distribution with $p$ numerator and $q$ denominator degrees of freedom

$F_{1-\alpha}(p, q)=(1-\alpha) 100$ th percentile of the central F-distribution with $p$ numerator and $q$ denominator degrees of freedom

$p=$ the number of parameters in the model

$q=$ the degrees of freedon associated with the estimate of $\sigma$ $\hat{\sigma}^{2}=$ estimate of experimental error variance.

The $(1-\alpha) 100 \% /(1-\gamma) 100 \%$ one-sided upper and two-sided tolerance bands on the fitted models are given by Equations (B.6) and (B.7) respectively,

$$
\hat{y}(\underline{x})+\hat{\sigma}\left\{\sqrt{p F_{1-\alpha}(p, q) \underline{x}^{\prime}\left(\underline{x}^{\prime} \underline{x}\right)^{-1} \underline{x}}+z_{1-\gamma}\left(\frac{q}{\underline{x}_{\alpha}^{2}(q)}\right)^{1 / 2}\right\}
$$




$$
\hat{y}(\underline{x}) \pm \hat{\sigma}\left\{\overline{p F_{1-\alpha / 2}(p, q) \underline{x}^{\prime}\left(\underline{x}^{\prime} \underline{x}\right)^{-1} \underline{x}}+z_{1-\gamma / 2}\left(\frac{q}{\underline{x}_{\alpha / 2}^{2}(q)}\right)^{1 / 2}\right\}
$$

where $z_{1-\gamma}=$ the $(1-\gamma) 100$ th percentile of the standard normal

$$
\begin{aligned}
& \chi_{\alpha}^{2}(q)=\text { the }(\alpha t h) \text { percentile of the central chi-square distribution } \\
& \text { with q degrees of freedom } \\
& \begin{aligned}
z_{1-\gamma / 2}= & \text { the }(1-\gamma / 2) 100 \text { th percentile of the standard normal } \\
& \text { distribution }
\end{aligned} \\
& x_{\alpha / 2}^{2}(q)=\text { the }(\alpha / 2 \text { th }) \text { percentile of the central chi-square distribution }
\end{aligned}
$$

Formulas (B.4) through (B.7) are extensions of the formulas given by Miller (1981, p. 124).

For $95 \%$ one-sided upper and two-sided confidence bands and $95 \% / 95 \%$ onesided upper and two-sided tolerance bands, $\alpha=0.05$ and $\gamma=0.05$. The quantity $\hat{\sigma}$ in equations (B.4) through (B.7) used to produce the confidence and tolerance band-based results given in Table 27 of this report were obtained via

$$
\hat{\sigma}=\hat{y}(x) * \% R S D
$$

where \%RSD is either the within-1ab or within-lab and lab-to-1ab \%RSD from Table 4.9 of this report. 

APPENDIX C

SHORT-TERM, LONG-TERM, AND LAB-TD-LAB VARIATIONS IN

GLASS ANALYSES, LEACH TESTING, AND LEACHATE ANALYSES 
APPENDIX $C$

\begin{abstract}
SHORT-TERM, LONG-TERM, AND LAB-TO-LAB VARIATIONS IN
GLASS ANALYSES, LEACH TESTING, AND LEACHATE ANALYSES
\end{abstract}

\title{
C.1 INTRODUCTION
}

In order to carry out the statistical approach for characterizing normalized boron release over the WV-8801-based compositional region, it was necessary to obtain estimates of the short-term within-1ab, long-term withinlab, and lab-to-lab standard deviations for the leach testing (including test preparation), leachate analysis, and glass analysis processes. To obtain information on the three lab-to-lab standard deviations and additional information on the six short- and long-term within-lab standard deviations, a limited "literature review" was performed. The results of the review are summarized in this appendix and an evaluation made regarding the uncertainty in normalized boron releases.

\section{C.2 STANDARD DEVIATION OF NORMALIZED BORON RELEASE}

The normalized boron releases (NBR) from the 7-day MCC-3 and 28-day MCC-1 and tests were computed as per Equations (1) and (2), respectively. The basic formula is repeated here for convenience:

$$
\mathrm{NBR}=C /(F *(W * S A) / V)
$$

where $\mathrm{NBR}=$ normalized boron release $\left(\mathrm{g} / \mathrm{m}^{2}\right)$

$\mathrm{C}=$ concentration of boron in the leachate $\left(\mathrm{ppm}\right.$ or $\mathrm{g} / \mathrm{m}^{3}$ )

$\mathrm{F}=$ fraction of boron in glass $=\left(.311 \mathrm{~g} \mathrm{~B} / \mathrm{g} \mathrm{B}_{2} \mathrm{O}_{3}\right) * w t \% \mathrm{~B}_{2} \mathrm{O}_{3}$ in glass)

$W=$ weight of glass sample leached

$\mathrm{SA}=$ surface area of $\mathrm{glass} / \mathrm{g}$ of $\mathrm{glass}\left(\mathrm{m}^{2} / \mathrm{g}\right)$

$V=$ volume of leachant $\left(\mathrm{m}^{3}\right)$.

Within the West Valley Support Task (WVST), it has been the practice to use the nominal SA/V value selected for the tests $\left(10 \mathrm{~m}^{-1}\right.$ for $M C C-1$ tests and 
$2000 \mathrm{~m}^{-1}$ for MCC -3 tests). This is acceptable provided the actual SA/V values vary randomly around the nominal value, in which case the variation in $S A / V$ in different tests will be observed as a variation in the elemental release concentrations, $C$, and thus be accounted for in the standard deviation formula below. However, the variability of NBR due to variations in $S A / V$ cannot be separately estimated.

The standard deviation of a single normalized release value (i.e., the value from a single analysis of leachate from a single leach test performed at a single 1ab) can be obtained via the general formula:

$$
S D(N B R)=N B R\left[[S D(C) / C]^{2}+[S D(W) / W]^{2}\right\}^{0.5}
$$

The quantity $S D(C)$ in (C.2) is given by the formula

$$
\mathrm{SD}(\mathrm{C})=\left(\mathrm{s}_{1}^{2}+\mathrm{s}_{2}^{2}+\cdots+\mathrm{s}_{6}^{2}\right)^{0.5}
$$

where $s_{1}=$ short-term leach test standard deviation

$s_{2}=$ long-term leach test standard deviation

$s_{3}=1 a b-t o-1 a b$ leach test standard deviation

$s_{4}=$ short-term leachate analysis standard deviation

$s_{5}=$ long-term leachate analys is standard deviation

$s_{6}=1 a b-t o-l a b$ leachate analysis standard deviation.

and it is assumed that the short-term, long-term, and lab-to-lab random errors in the leach testing (including sample preparation) and leachate anatysis processes are independent.

The quantity $S D(W)$ in (C.2) is given by the formula

$$
\mathrm{SD}(W)=\left(s_{7}^{2}+s_{8}^{2}+s_{9}^{2}\right)^{0.5}
$$

where $s_{7}=$ short-term glass analysis standard deviation for $\mathrm{B}_{2} \mathrm{O}_{3}$ in the glass

$\mathrm{s}_{8}=$ long-term gTass analysis standard deviation for $\mathrm{B}_{2} \mathrm{O}_{3}$ in the glass 


$$
\begin{aligned}
& \mathrm{s}_{9}=\text { lab-to-lab glass analysis standard deviation for } \mathrm{B}_{2} \mathrm{O}_{3} \\
& \text { in the glass }
\end{aligned}
$$

and it is assumed that the short-term, long-term, and lab-to-lab random errors in the $g$ lass analysis process are independent. Note that $s_{7}, s_{8}$, and $s_{9}$ have values for each oxide component in the glass, but only $\mathrm{B}_{2} \mathrm{O}_{3}$ is of concern here relative to computing the uncertainty in normalized boron releases.

In the following section, the results of the literature review to collect information on previous estimates of $s_{1}$ through $s_{9}$ are given.

\section{C.3 RESULTS OF LITERATURE REVIEW}

Tables C.I to C.7 contain the results of the literature review for estimates of short-term within-1ab, long-term within-1ab, and lab-to-lab standard deviations. Leach testing (including specimen preparation) and leachate analysis standard deviations are given in Tables C.1 to C.4, while glass analysis standard deviations are given in Tables C.5 to C.7. Results in Tables $C .1$ to $C .4$ are given for "as-analyzed" concentrations and normalized releases of boron. Because boron is the element of most interest, literature review efforts focused on collecting $B$ information. The "as-analyzed" B concentration values are the ones directly applicable to Equation ( $C .3$ ), but the normalized release values can also be used when working with \% relative standard deviation (\%RSD) versions of Equations (C.2) and (C.3). Specific discussions of each table are given below.

Tables C.1 and C.2 summarize short-term within-lab standard deviations for the leach testing and leachate analysis processes. Table C.l presents results for MCC-1 testing of several glasses, while Table C.2 presents results for MCC-3 testing of several glasses. The "Proc. SD" and "Ana1. SD" columns in Tables $C .1$ and $C .2$ contain estimates of $s_{1}$ and $s_{4}$, respectively. 
IABLE C.1. Short-Term Procedural and Analytic Uncertainties in Boron Concentrations from MCC-1 Testing at $90^{\circ} \mathrm{C}$ in DIW

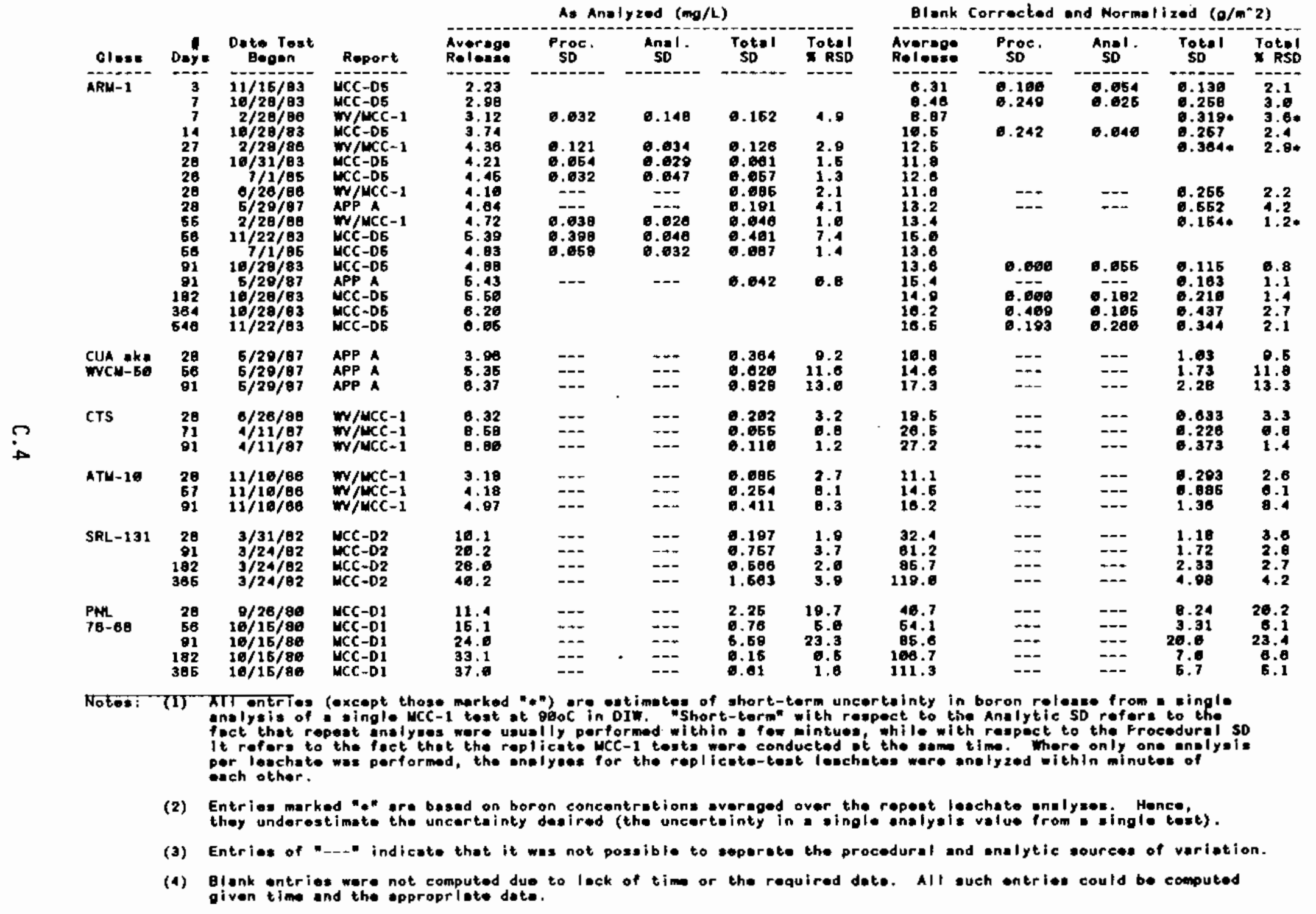


IABLE C.2. Short-Term Procedural and Analytic Uncertainties in Boron Concentrations from MCC-3 Testing at $90^{\circ} \mathrm{C}$ in DIW

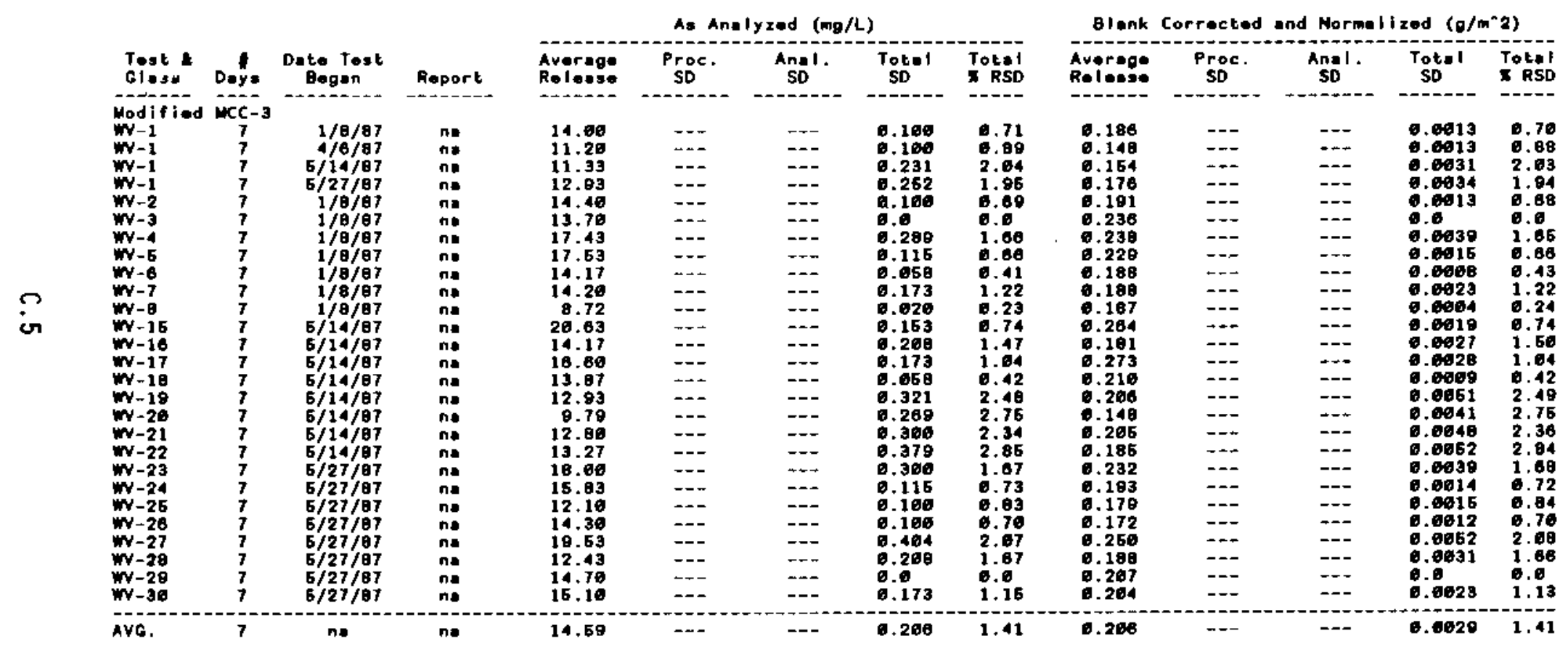


TABLE C.2. (contd)

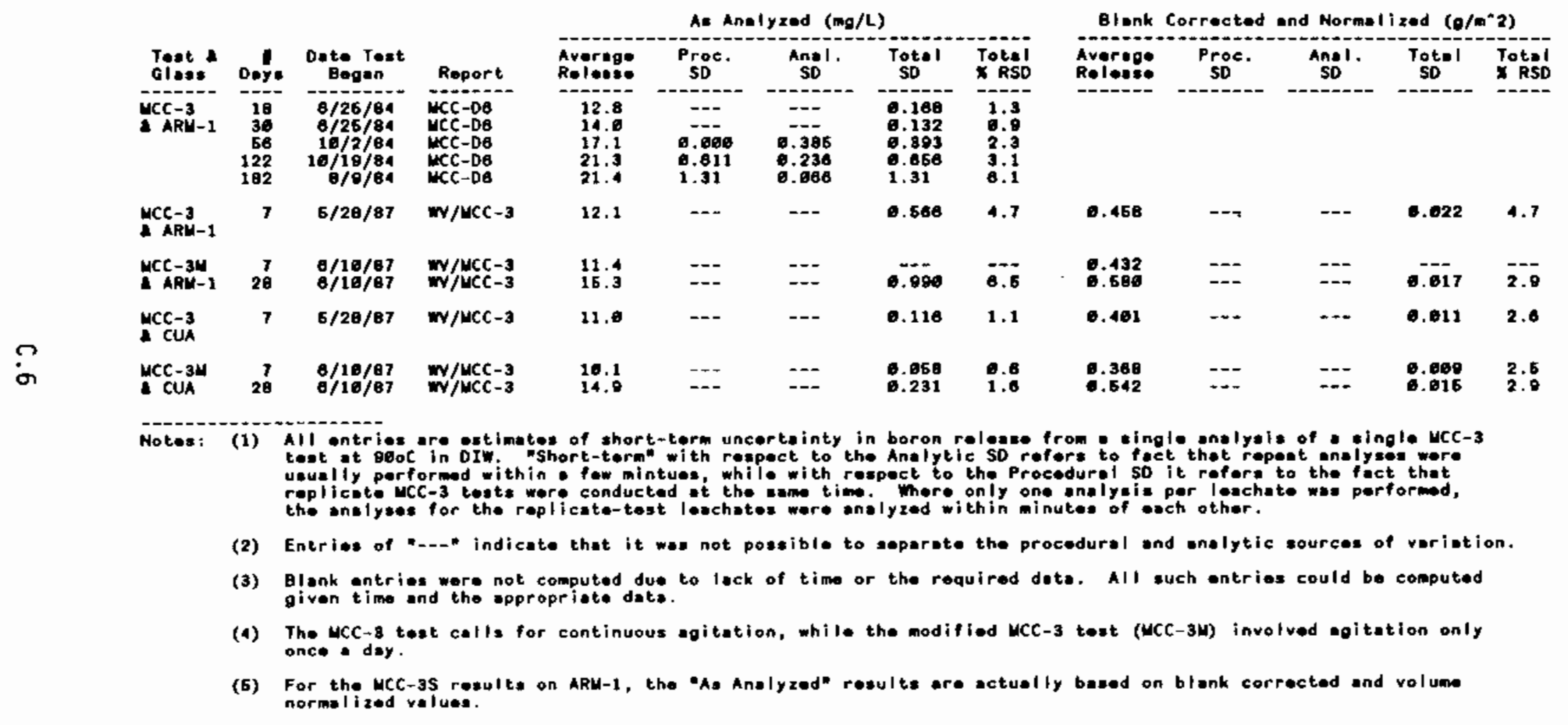


TABLE C.3. Long-Term Procedural Plus Analytic, Short-Term Procedural, and Short-Term Analytic Uncertainties in Boron Concentrations from MCC-1 and MCC-3 Testing at $90^{\circ} \mathrm{C}$ in DIW

\begin{tabular}{|c|c|c|c|c|c|c|c|c|c|c|c|c|c|}
\hline \multirow[b]{2}{*}{$\begin{array}{l}\text { Te*t L } \\
\text { Glos: }\end{array}$} & \multirow[b]{2}{*}{ Doy: } & \multicolumn{6}{|c|}{$A=$ Anelyzod $(\mathrm{mg} / \mathrm{L})$} & \multicolumn{6}{|c|}{ Blank Corrected and Normatlued $\left(0 / m^{\wedge} 2\right)$} \\
\hline & & $\begin{array}{l}\text { Averego } \\
\text { Rolessose }\end{array}$ & $\begin{array}{l}\text { Long-Torm } \\
\text { SD }\end{array}$ & $\begin{array}{l}\text { Proc. Short } \\
\text { Pro }\end{array}$ & Anermi. SD & $\begin{array}{c}\text { Totol } \\
\text { SD }\end{array}$ & $\begin{array}{l}\text { Jatel } \\
\times \text { RSD }\end{array}$ & Avarage & Long Torm & Proc. So & Anst. SD & $\begin{array}{c}\text { Tot=1 } \\
\text { SD }\end{array}$ & $\begin{array}{l}\text { Totel } \\
\text { N RSD }\end{array}$ \\
\hline $\begin{array}{c}\text { MCC } 11 \\
\text { ARM-1 }\end{array}$ & $\begin{array}{r}7 \\
28 \\
58 \\
91\end{array}$ & $\begin{array}{l}1.33 \\
4.98\end{array}$ & $\begin{array}{l}0.176 \\
6.317\end{array}$ & $\begin{array}{l}0.604 \\
0.264\end{array}$ & $\begin{array}{l}0.638 \\
6.63 \mathrm{E}\end{array}$ & $\begin{array}{l}0.193 \\
0.378\end{array}$ & 4.6 & & & & & & \\
\hline$\underset{W-1}{M C C-3}$ & 7 & 12,37 & 1.340 & ---- & $185----$ & 1.352 & 16.8 & 6.186 & 0.018 & $---\infty . \infty$ & $326-----$ & 6.018 & 10.0 \\
\hline
\end{tabular}

Notes: (1) Long-torm SDs ore estimates of the uncerteinty in boron rolesse due to tibo-reloted randon variations in the Long-term SOs ore ostimates of the uncerteinty in boron relesse due to tibo-reloted randon variations in the and the resulting leachate snalyzed once, the boron relense is stił aubject to lono-term variation. The foct

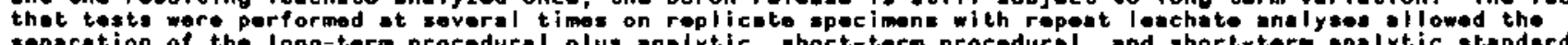

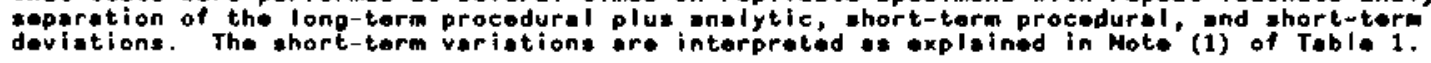

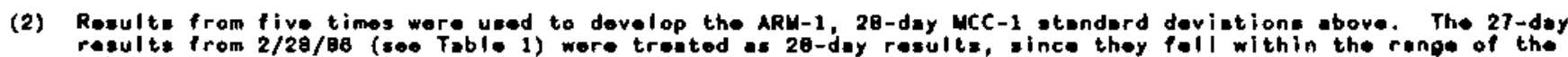
reavitio Prom $2 / 28 / B 8$

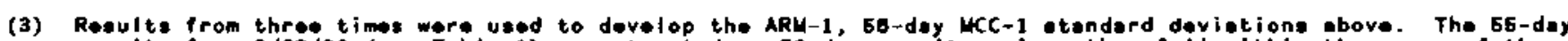
resultg from $2 / 28 / 86$ (900 Table 1) wore treeted as be-day results, since they foll within the range of the othar s6-day rasults.

(4) Resulte from four timas wore used to develop the W-1, 7-day ucc-3 atendard devintions above.

(5) Entries merked by "---" indicoto thet the short-term procedural and analytle senderd devietions could not bo seperately estimated bocauso only ono onalyais per leachate was performad.

(6) Blenk entries were not computed due to leck of time or the required dots. All wuch ontrias could be compuled given time and the appropriote dats. 
TABLE C.4. Lab-to-Lab Uncertainties in Boron Concentrations from 28-Day MCC-1 Testing of NBS Glass, MCC 76-68 Glass, and UK209 G1ass at $90^{\circ} \mathrm{C}$ in $\mathrm{DIH}$

\begin{tabular}{|c|c|c|c|c|c|c|c|c|}
\hline $\begin{array}{l}\text { Round } \\
\text { Robin (v) }\end{array}$ & $\begin{array}{l}\text { Concentralion } \\
\text { Range (ppm) }\end{array}$ & $\begin{array}{l}\text { Average Norm. } \\
\text { Ro lose }\left(g / m^{-} 2\right)\end{array}$ & WD $_{\text {With }}$ & -Leb & $\begin{array}{l}\text { Betwee } \\
\text { SD }\end{array}$ & -Labs & so ${ }^{T_{0}}$ & 'xRSD \\
\hline $\begin{array}{l}\text { YCC } 78-68 \\
\text { MCC NOS }\end{array}$ & $7.5-18.6$ & $\begin{array}{l}38.6 \\
17.8\end{array}$ & $\begin{array}{l}3.08 \\
2.88\end{array}$ & $\begin{array}{r}8.4 \\
18.2\end{array}$ & 11.2 & 81.0 & $\begin{array}{l}11.0 \\
11.8\end{array}$ & 60.1 \\
\hline CEC UK 260 & $2.4-4.0$ & 10.6 & 6.42 & 4.6 & 2.6 & 10.0 & 2.1 & 18.4 \\
\hline
\end{tabular}
Notes: (1) The concentretion range end overage relesse information is with respect to all labe
porticipeting in the round robin.

(2) The within-tab SD and XRSD above involves only short-term voriation to the oxtent thet the replicate toste performed by given lab wore conducted and lenchaten onalyzod ot the same timo. The round robin test plon did not provide for ostimating the long-tare within-lab veriation. Thus an unknown portion of the between-labe so ond wRSD may be ittributeble 
IABLE C.5. Short-Term Uncertainties in Boron Glass Analyses by ICP(a)

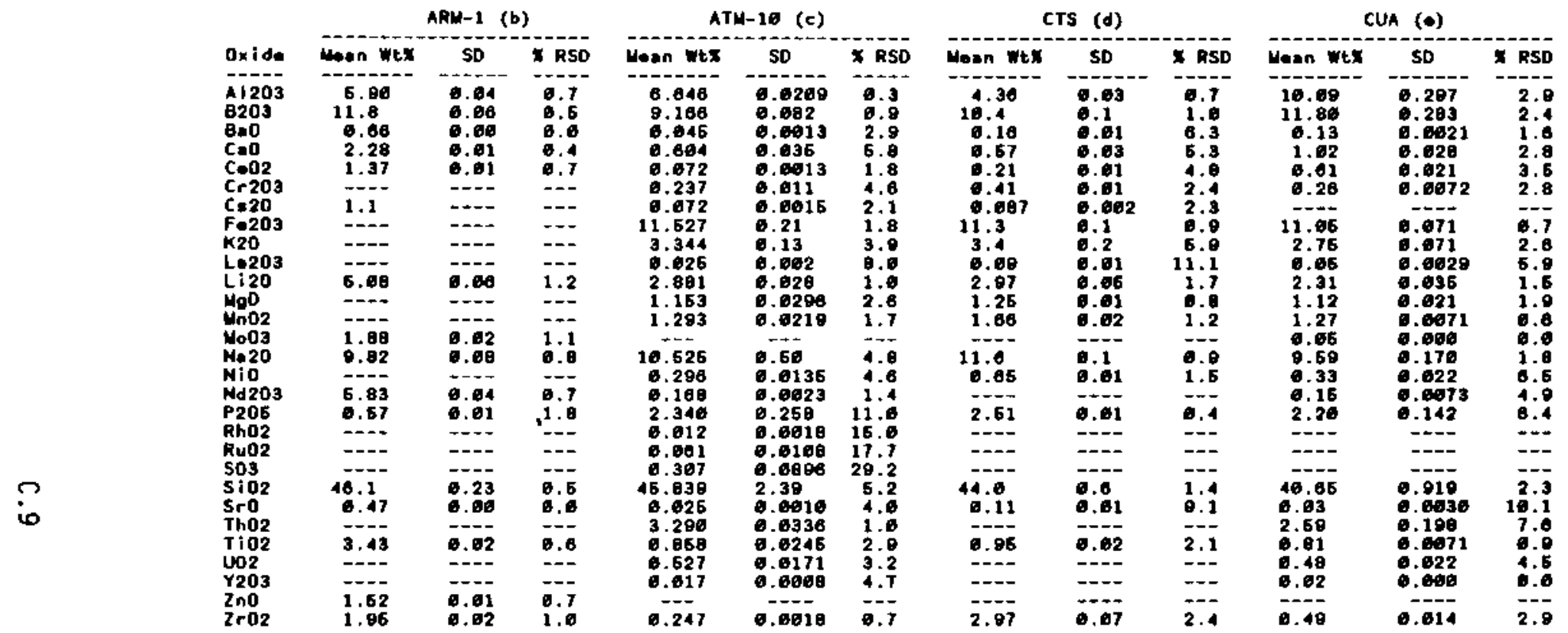

(6) Result: in this teble are besed on ex-analyzed wo ight porcent values, obtoined by ICP. In o fow cases the results worb obteinod by AA or EDXFF.

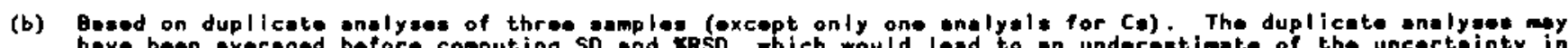
heve been averaped bofore computing SO ond XRSO, which would lead to on underestimate of the uncertainty in

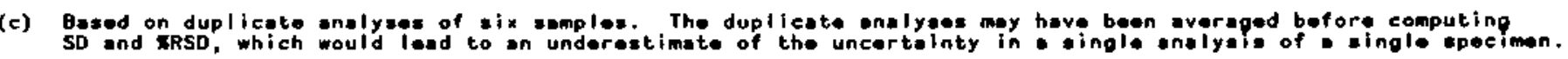

(d) Bused on one ansiyais each of three samples.

(a) Besed on one analyeis each of two eamplas. 
IABLE C.5. (contd)

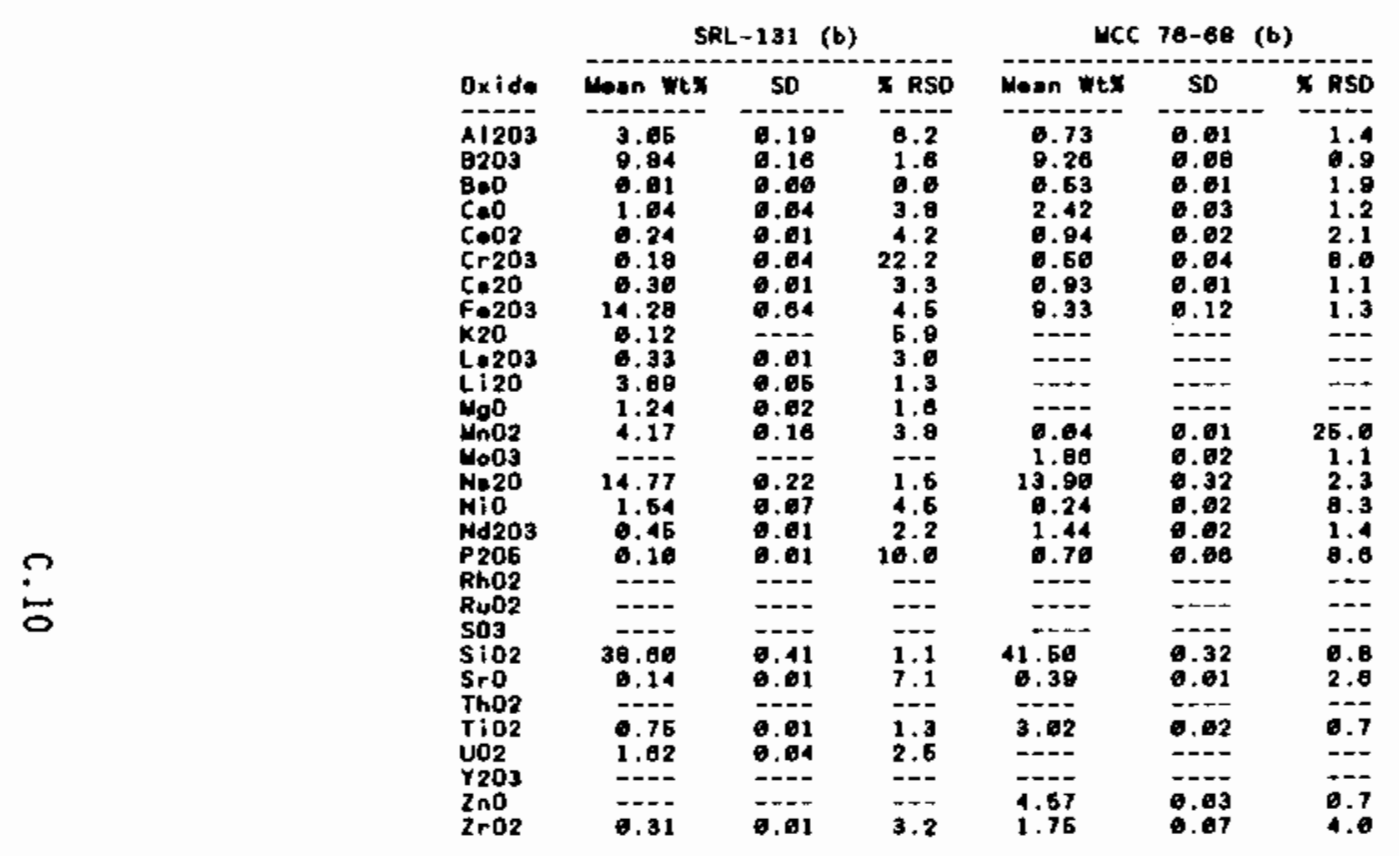

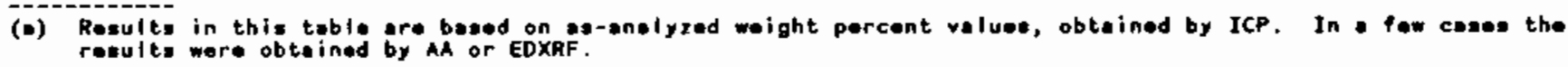

(b) Based on aingle analysis of each of three samples. 
TABLE C.6. Combined Short- Plus Long-Term(a) Within Lab Uncertainties in Normalized(b) Glass Analyses for Glasses WV-1, WV-2, and WV-15 to WV-30

\begin{tabular}{|c|c|c|c|c|c|}
\hline Oxide & $\begin{array}{l}\text { WVCM-50/ } \\
\text { WV-30 Wt\% }\end{array}$ & $\begin{array}{l}\text { Largest } \\
\text { SD (c) }\end{array}$ & $\begin{array}{l}\text { Pooled } \\
\text { SD }\end{array}$ & $\begin{array}{l}\text { Largest } \\
\text { \%RSD (c) }\end{array}$ & $\begin{array}{l}\text { Pooled } \\
\text { \%RSD (d) }\end{array}$ \\
\hline---- & --n-- & - - & ----- & --n--.- & --n-n \\
\hline A1203 & 10.265 & 0.438 & 0.196 & 3.6 & 1.8 \\
\hline B203 & 11.820 & 0.233 & 0.126 & 1.7 & 1.1 \\
\hline $\mathrm{BaO}$ & 0.200 & 0.007 & 0.005 & 9.7 & 5.4 \\
\hline $\mathrm{CaO}$ & 0.825 & 0.177 & 0.049 & 21.2 & 6.7 \\
\hline $\mathrm{CeO} 2$ & 0.670 & 0.085 & 0.043 & 39.9 & 22.7 \\
\hline $\mathrm{Cr} 203$ & 0.145 & 0.035 & 0.012 & 20.2 & 8.0 \\
\hline $\operatorname{cs} 20$ & 0.045 & 0.014 & 0.009 & 28.3 & 18.1 \\
\hline Fe203 & 11.470 & 0.375 & 0.159 & 3.1 & 1.4 \\
\hline $\mathrm{K} 20$ & 1.810 & 0.643 & 0.395 & 59.8 & 24.3 \\
\hline Li20 & 2.125 & 0.205 & 0.066 & 12.4 & 3.7 \\
\hline $\mathrm{MgO}$ & 0.945 & 0.106 & 0.053 & 13.8 & 6.3 \\
\hline $\mathrm{MnO} 2$ & 1.205 & 0.071 & 0.025 & 2.9 & 1.2 \\
\hline $\mathrm{Na} 20$ & 9.640 & 0.757 & 0.422 & 7.9 & 4.4 \\
\hline NiO & 0.340 & 0.240 & 0.055 & 68.7 & 16.1 \\
\hline P205 & 2.465 & 0.318 & 0.160 & 20.4 & 7.8 \\
\hline $\mathrm{SiO} 2$ & 40.040 & 0.566 & 0.282 & 1.5 & 0.7 \\
\hline Th02 & 3.125 & 0.848 & 0.239 & 22.6 & 7.4 \\
\hline $\mathrm{TiO}$ & 0.820 & 0. & 0.024 & 7.1 & 2.6 \\
\hline UO2 & 20 & 0 . & 0.047 & 22.3 & 8.7 \\
\hline $2 \mathrm{r} 02$ & 0.615 & 0.198 & 0.088 & 26.6 & 14.9 \\
\hline
\end{tabular}

(a) WV-1 (WVCM-47) was analyzed twice each on $1 / 2 / 87$ and $6 / 3 / 87$, and once each on $6 / 11 / 87$ and $7 / 7 / 87$. WV-2 was analyzed twice on $1 / 2 / 87$. G1asses WV-15 to WV-22 were analyzed once each on $6 / 3 / 87$ and $6 / 11 / 87$. Glasses WV-23 to WV-30 were analyzed once each on $6 / 3 / 87$ and $7 / 7 / 87$. While it is possible to separately estimate short-term (i.e., within day) uncertainty for WV-1 and WV-2, it is not possible to do so for the other glasses. For simplicity, all analyses for each giass were treated as if they incorporate both short- and long-term uncertainty. This results in a combined estimate of short-plus long-term uncertainty for each oxide component.

(b) Results in this table are based on normalized (to 100\%) weight percent values obtained from the as-analyzed weight percents. The results are quite similar for the as-analyzed (unnormalized) data.

(c) The largest values of SD and \%RSD indicate the range of values for each quantity over the 18 glasses considered. The \%RSD values are relative to the mean composition of each glass, not relative to the WVCM-50 (WV-30) composition given above. The WVCM-50 (WV-30) composition is listed as representative of the region of compositions covered by these glasses.

(d) The pooled SD and \%RSD values are "combined" estimates over the individual SDs and \%RSDs for each glass. 
TABLE C.7. Lab-to-Lab Uncertainties in ARM-1 Glass Analyses at Three PNL Labs

\begin{tabular}{|c|c|c|c|c|c|c|c|}
\hline oxide & Mean wt\% & $\begin{array}{l}\text { SD } \\
\text { Labs }\end{array}$ & $\begin{array}{l}\text { \%RSD } \\
\text { Labs }\end{array}$ & $\begin{array}{c}\text { SD } \\
\text { Days }\end{array}$ & $\begin{array}{l}\text { \%RSD } \\
\text { Days }\end{array}$ & $\begin{array}{l}\text { Total } \\
\text { SD }\end{array}$ & $\begin{array}{r}\text { Total } \\
\text { \%RSD }\end{array}$ \\
\hline---- & - - - & ----・-- & ---- & ------- & $=---$ & 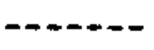 & ----- \\
\hline A 1203 & 5. B9 & 0.128 & 2.2 & 0.102 & 1.7 & 0.164 & 2.8 \\
\hline B203 & 11.85 & 0.459 & 3.9 & 0.225 & 1.9 & 0.511 & 4.3 \\
\hline $\mathrm{BaO}$ & 0.66 & 0.013 & 2.0 & 0.009 & 1.4 & 0.016 & 2.4 \\
\hline $\mathrm{CaO}$ & 2.22 & 0.050 & 2.2 & 0.036 & 1.6 & 0.062 & 2.8 \\
\hline $\mathrm{CeO} 2$ & 1.27 & 0.0 & 0.0 & 0.121 & 9.5 & 0.121 & 9.5 \\
\hline Li20 & 4.95 & 0.237 & 4. $B$ & 0.074 & 1.5 & $0.24 B$ & 5.0 \\
\hline MoO3 & 1.83 & 0.0 & 0.0 & 0.036 & 2.0 & 0.036 & 2.0 \\
\hline $\mathrm{Na} 20$ & 9.55 & 0.220 & 2.3 & 0.377 & 3.9 & 0.436 & 4.6 \\
\hline $\mathrm{Nd} 203$ & 5.80 & 0.064 & 1.1 & 0.074 & 1.3 & 0.098 & 1.7 \\
\hline P205 & 0.55 & 0.033 & 6.1 & 0.079 & 14.4 & 0.086 & 15.6 \\
\hline Si02 & 44.52 & 1.41 & 3.2 & 0.800 & 1.8 & 1.62 & 3.6 \\
\hline Sro & 0.46 & 0.006 & 1.4 & 0.007 & 1.5 & 0.009 & 2.0 \\
\hline Ti02 & 3.36 & 0.095 & 2.8 & 0.054 & 1.6 & 0.109 & 3.3 \\
\hline & 1.4 & 0.012 & 0.8 & 0.027 & 1.8 & 0.030 & 2.0 \\
\hline ( & 1.9 & 0.093 & 4.7 & 0.048 & 2.4 & 0.105 & 5.3 \\
\hline
\end{tabular}

Note: Results in this table are based on as-analyzed (not normalized to 100) weight percent values. Each lab analyzed ARM-l glass several times a day on four or five days over a two week period during April 1986. The results were not previously published, and it is unclear whether the "Days SD" includes within day uncertainty with respect to single determinations, or with respect to the average for the day. Thus, although it is clear that the Total SD and Total \%RSD contain lab-to-lab and long-term (between days) uncertainty, it is not ciear whether the short-term (within day) uncertainty is fully represented.

Where it was not possible to separately estimate $s_{1}$ and $s_{4}$, the "Total SD" column contains combined estimates of $\left(s_{1}^{2}+s_{4}^{2}\right)^{0.5}$.

Table C. 3 contains estimates of long-term within-lab standard deviations for the leach testing and leachate analysis processes. It was not possible to separately estimate the long-term standard deviations for these two processes, so a combined estimate [i.e., $\left.\left(s_{2}^{2}+s_{5}^{2}\right)^{0.5}\right]$ is given in the "LongTerm SD" column. The "Short-Term" column contains pooled estimates of $s_{1}$ and $s_{4}$ (over the multiple times a given glass was tested).

Table C. 4 contains results on lab-to-lab standard deviations from 28-day MCC -1 tests at $90^{\circ} \mathrm{C}$ in DIW (or the equivalent thereof in the case of the CEC 
results). The results are for normalized releases, and do not separate out the leach testing, leachate analysis, and glass analysis standard deviations. Because each lab only performed the leach testing (including specimen and leachant preparation) and leachate analysis, the results in Table C.4 do not include an estimate of glass analysis uncertainty. Roughly speaking then, the "Between-Labs" columns in Table C.4 provide estimates of the contributions of $s_{3}$ and $s_{5}$. However, it is not clear to what extent this lab-to-lab variation (which is very large) is actually composed of long-term within-lab variation. The "Within-Lab" columns only deal with short-term within-1ab variation.

Table C.5 contains short-term glass analys is standard deviations (i.e., $s_{7}$ ) by oxide for six glasses. Although some of the glasses contain similar weight percents of certain oxides, the standard deviations vary quite a bit (e.g., the $\mathrm{SiO}_{2}$ values range from approximately 39 to $46 \%$, but have relative standard deviations ranging from 0.5 to $5.2 \%$ ).

Table C. 6 contains combined estimates of short- and long-term glass analysis standard deviations [i.e., $\left(s_{7}^{2}+s_{8}^{2}\right)^{0.5}$ ]. Seventeen different glasses were analyzed twice each at different times, and another glass was analyzed six times. The maximum standard deviation (for each oxide component) over the $18 \mathrm{glasses}$ is 1 isted (the minimum was nearly always zero). The results were also "pooled" over the 18 glasses to give an idea of the "average" standard deviation for each oxide.

Table $C .7$ contains estimates of lab-to-lab glass analysis standard deviations (i.e., $s_{g}$ ) by oxide. The estimates are based on analyses of ARM-1 glass by three different PNL labs. Because the three labs used similar procedures and performed the analyses in the same time frame, the variation observed may be less than what would have been observed if the labs were not "re1ated" and the analyses were spread further apart in time.

\section{C.4 EVALUATION OF LITERATURE REVIEW RESULTS}

Table $C .8$ contains a summary of the standard deviations contained in Tables C.1 through C.7, presented as \%RSDs to simplify the presentation. The results vary quite a bit from study to study and glass to glass, so ranges 
TABLE C.8. Sunmary of Relative Standard Deviations from Tables C.1-C.7 and Estimation of the Uncertainty in a Single Normalized Boron Release Value

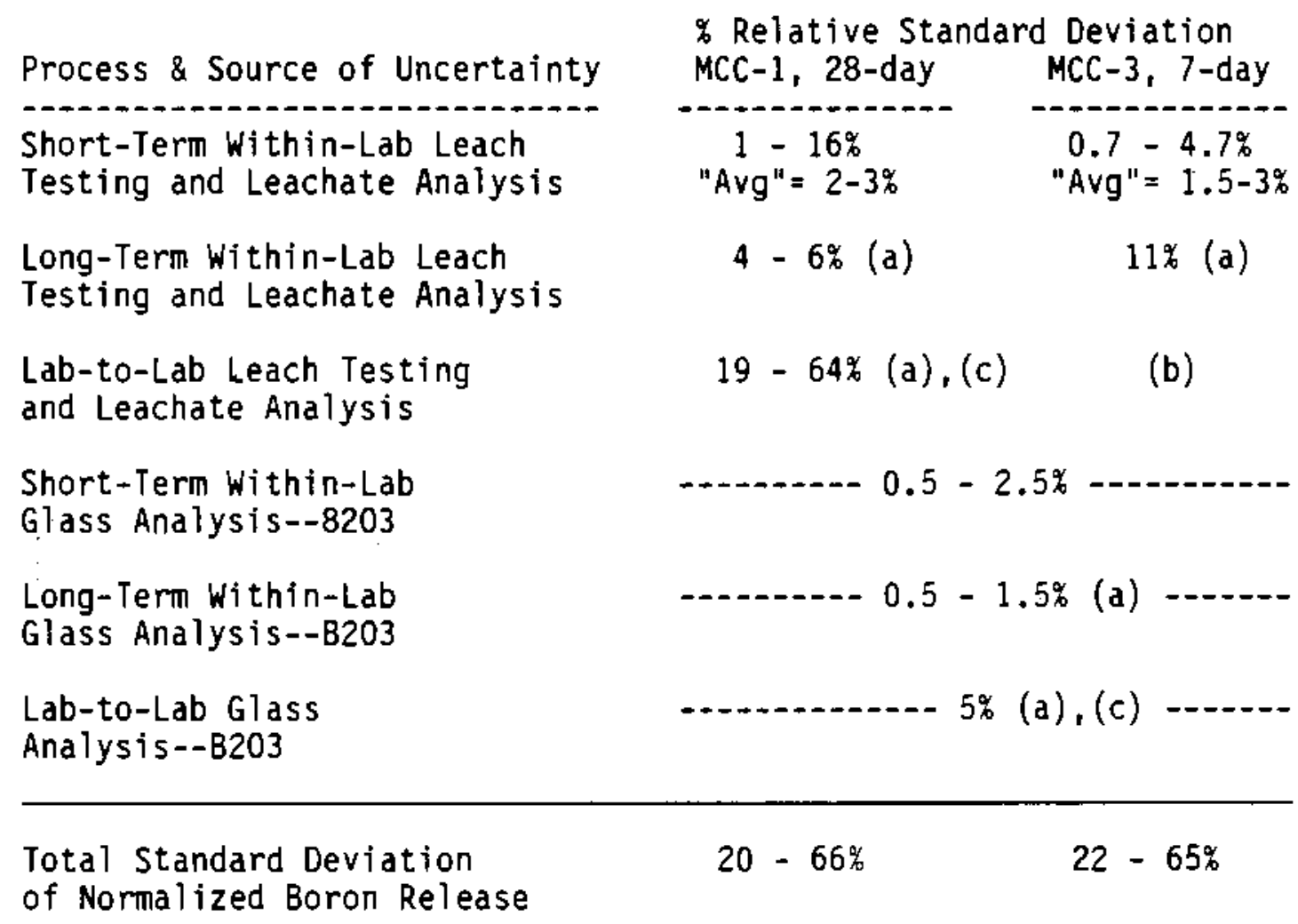
(a) These values are fairly uncertain as they are based on limited data.
(b) No studies with multiple labs conducting MCC-3 tests have been performed. For purposes of computing the normalized boron release total standard deviation, the range of $19-64 \%$ from the MCC -1 tests was used.
(c) The lab-to-lab variation may also include long-term within-lab variation. It was not possible to separately estimate these two sources of variation.

have been presented in Table C.8. It is clear that the total uncertainty (including all short- and long-term within-lab and lab-to-lab variations) in normalized boron release is probably at least $20 \%$ for both the 28 -day MCC-1 and 7-day MCC-3 tests. The total uncertainty may be as high as 60 to $70 \%$. 
Analyzing glasses more than once, performing leach tests on a glass more than once, and performing more than one analysis per leachate--and then averaging the normalized releases--can be done to reduce the uncertainty. However, these repeated activities would have to be performed at different times at different labs to reduce the long-term within-lab and lab-to-lab contributions to the total uncertainty. The usual practice of repeating leach tests and leachate analyses at the same time at the same lab (and averaging the results) only reduces short-term within-lab uncertainties, which appear to be a small contributor to the total uncertainty. Lab-to-lab and long-term within-lab variations are the main contributors to the total uncertainty. 



\section{APPENDIX D}

ESTIMATES OF SHORT - AND LONG-TERM WITHIN-LAB UNCERTAINTIES BASED ON REPEAT GLASS ANALYSES, REPEAT LEACHATE ANALYSES, AND REPEAT LEACH TESTS 
APPENDIX D

\section{ESTIMATES OF SHORT - AND LONG-TERM WITHIN-LAB UNCERTAINTIES BASED ON REPEAT GLASS ANALYSES, REPEAT_LEACHATE_ANALYSES, AND REPEAT LEACH TESTS}

This appendix contains estimates of short- and long-term within-lab percent relative standard deviations (\%RSD) associated with the glass analysis, leachate analysis, and leach testing processes. These results were obtained from FY 1988 work in which certain glass analyses, leachate analyses, and leach tests were repeated over time.

Tables 0.1 through 0.3 contain \%RSDs from repeated compositional analyses of three glasses: Corning-A, ARM-1, and NBS-SRM-1411. These results are not of direct interest, but provide supporting information for the \%RSDs of the repeat analyses of three FY 1988 composition variation glasses, DG-WV33, DG-WV34, and DG-WV44. The \%RSDs for these three glasses are given in Table 0.4. Details on the number of repeat analyses and the interpretation of the \%RSDs reported are given as footnotes in Tables 0.1 through 0.4 .

Table 0.5 contains the \%RSDs from repeat analyses of leachates from 7-day MCC-3 and 28-day MCC-1 tests of glasses DG-WV33, DG-WV34, and DG-WV44. Note that aliquots of the same leachate for each glass were analyzed repeatedly, so that only leachate analysis uncertainty is estimated.

On the other hand, Table 0.6 contains \%RSDs from repeat 7 -day MCC-3 and 28-day MCC-1 leach tests. Hence, these \%RSDs include variations in the leach testing procedures as well as in the leachate analysis procedure. It is interesting to observe that the \%RSDs in Table 0.6 are of approximately the same magnitude as those in Table D.5. This indicates that the variation in results due to the leach testing process is very small compared to the variation in leachate analys is results. 
IABLE D.1. Short-Term, Long-Term, and Total Within-Lab \%RSD in As-Analyzed (Unnormalized) ICP Anatyses of Corning-A Glass

\begin{tabular}{|c|c|c|c|c|c|}
\hline $\begin{array}{c}\text { Oxide } \\
\text { Component }\end{array}$ & $\begin{array}{c}\operatorname{Mean}(\mathrm{a}) \\
\mathrm{Wt} \% \\
\end{array}$ & $\begin{array}{l}\text { Short-Term } \\
\text { Within-Lab } \\
\text { \%RSD (b) }\end{array}$ & $\begin{array}{l}\text { Long-Term } \\
\text { Within-Lab } \\
\text { \%RSD (c) }\end{array}$ & $\begin{array}{c}\text { Total } \\
\text { Within-Lab } \\
\text { \%RSD (d) } \\
\end{array}$ & $\begin{array}{c}\text { Total } \\
\text { Within-Lab } \\
\text { \%RSE }(\mathrm{e}) \\
\end{array}$ \\
\hline $\mathrm{Al}_{2} \mathrm{O}_{3}$ & 10.53 & 0.00 & 1.10 & 1.10 & 0.64 \\
\hline $\mathrm{B}_{2} \mathrm{O}_{3}$ & 8.77 & 0.14 & 1.33 & 1.34 & 0.77 \\
\hline $\mathrm{CaO}$ & 0.48 & 0.84 & 14.31 & 14.33 & 8.27 \\
\hline $\mathrm{Fe}_{2} \mathrm{O}_{3}$ & 12.75 & 0.32 & 2.17 & 2.20 & 1.26 \\
\hline $\mathrm{K}_{2} \mathrm{O}$ & 1.08 & 19.02 & 35.81 & 40.55 & 22.08 \\
\hline $\mathrm{Li}_{2} \mathrm{O}$ & 2.01 & 0.61 & 2.74 & 2.80 & 1.60 \\
\hline $\mathrm{MgO}$ & 0.82 & 0.50 & 5.64 & 5.66 & 3.26 \\
\hline $\mathrm{MnO}_{2}$ & 1.30 & 0.31 & 2.10 & 2.13 & 1.22 \\
\hline $\mathrm{Na}_{2} \mathrm{O}$ & 7.79 & 1.64 & 4.90 & 5.17 & 2.91 \\
\hline $\mathrm{P}_{2} \mathrm{O}_{5}$ & 2.35 & 3.88 & 4.91 & 6.26 & 3.25 \\
\hline $\mathrm{SiO}_{2}$ & 45.08 & 0.49 & 1.03 & 1.14 & 0.63 \\
\hline $\mathrm{TiO}_{2}$ & 0.81 & 1.13 & 0.50 & 1.24 & 0.54 \\
\hline $\mathrm{ZrO}_{2}$ & 2.20 & 0.87 & 6.99 & 7.05 & 4.05 \\
\hline
\end{tabular}

(a) The glass was analyzed for composition two times on each of three dates $(5 / 24 / 88,7 / 15 / 88$, and $8 / 15 / 88)$ for a total of six analyses. The mean weight percent oxides are averages of the six values obtained for each oxide.

(b) The short-term within-lab percent relative standard deviation quantifies the variation in analyses performed on the same day. The standard deviation of an individual analysis is reported, not the standard deviation of the mean weight percent oxide. Also, note that the short-term \%RSDs are based on only three degrees of freedom (i.e., duplicate analyses were performed on only three days), and hence are uncertain.

(c) The long-term within-1ab percent relative standard deviation quantifies the variation in analyses performed over the space of a few months. The standard deviation of an individual analysis is reported, not the standard deviation of the mean weight percent oxide. Also, note that the long-term \%RSDs are based on only two degrees of freedom (i.e., analyses were only made on three different dates), and hence are quite uncertain.

(d) The total within-lab percent relative standard deviation includes both short- and long-term within-lab variation in glass analyses, and quantifies the total within-lab uncertainty in a single ICP analysis.

(e) The total within-lab percent relative standard error includes both short- and long-term within-lab variation in glass analyses, and quantifies the total within-lab uncertainty in the estimated Corning-A composition (obtained as an average of six analyses). 
TABLE D.2. Short-Term, Long-Term, and Total Within-Lab \%RSD in As-Analyzed (Unnormalized) ICP Analyses of ARM-1 Glass

\begin{tabular}{|c|c|c|c|c|}
\hline $\begin{array}{c}\text { Oxide } \\
\text { Component }\end{array}$ & $\begin{array}{c}\operatorname{Mean}(\mathrm{a}) \\
\text { Wt\% } \\
\end{array}$ & $\begin{array}{l}\text { Short-Term (b) } \\
\text { Within-Lab \%RSD }\end{array}$ & $\begin{array}{l}\text { Long-Term }(c) \\
\text { Within-Lab \%RSD }\end{array}$ & $\begin{array}{c}\text { Total (d) } \\
\text { Within-Lab \%RSD }\end{array}$ \\
\hline $\mathrm{Al}_{2} \mathrm{O}_{3}$ & 5.68 & 0.28 & 3.18 & 3.19 \\
\hline $\mathrm{B}_{2} \mathrm{O}_{3}$ & 11.68 & 1.35 & 1.97 & 2.39 \\
\hline $\mathrm{BaO}$ & 0.64 & 1.58 & 3.42 & 3.77 \\
\hline $\mathrm{CaO}$ & 2.35 & 0.48 & 5.63 & 5.65 \\
\hline $\mathrm{Ce}_{2} \mathrm{O}$ & 1.44 & 1.10 & 2.95 & 3.15 \\
\hline $\mathrm{Cs}_{2} \mathrm{O}$ & 1.11 & 3.23 & 6.97 & 7.69 \\
\hline $\mathrm{Li}_{2} \mathrm{O}$ & 4.70 & 0.75 & 7.55 & 7.59 \\
\hline $\mathrm{MoO}_{3}$ & 1.91 & 0.78 & 1.66 & 1.83 \\
\hline $\mathrm{Na}_{2} \mathrm{O}$ & 9.55 & 1.48 & 4.26 & 4.51 \\
\hline $\mathrm{Nd}_{2} \mathrm{O}_{3}$ & 5.39 & 1.60 & 4.34 & 4.62 \\
\hline $\mathrm{P}_{2} \mathrm{O}_{5}$ & 0.56 & 8.51 & 41.76 & 42.62 \\
\hline $\mathrm{SiO}_{2}$ & 44.98 & 1.75 & 3.01 & 3.48 \\
\hline Sro & 0.46 & 0.00 & 3.96 & 3.96 \\
\hline $\mathrm{TiO}_{2}$ & 3.29 & 0.48 & 2.05 & 2.11 \\
\hline $\operatorname{ZnO}$ & 1.52 & 1.04 & 5.95 & 6.04 \\
\hline $\mathrm{ZrO}_{2}$ & 1.91 & 2.07 & 8.18 & 8.44 \\
\hline
\end{tabular}

(a) The glass was analyzed for composition two times each on $4 / 1 / 88$ and $5 / 13 / 88$, and once each on $5 / 24 / 88,6 / 8 / 88,7 / 15 / 88$, and $8 / 15 / 88$, for a total of eight anaiyses. The mean weight percent oxides were obtained by computing the mean for each day, and then averaging the values from the six days.

(b) The short-term within-lab percent relative standard deviation quantifies the variation in analyses performed on the same day. The standard deviation of an individual analysis is reported, not the standard deviation of the mean weight percent oxide. Also, note that the short-term \%RSDs are based on only two degrees of freedom (i.e., analyses were repeated on only two days), and hence are quite uncertain.

(c) The long-term within-lab percent relative standard deviation quantifies the variation in analyses performed over the space of a few months. The standard deviation of an individual analys is is reported, not the standard deviation of the mean weight percent oxide. Also, note that the long-term \%RSDs are based on only 5 degrees of freedom (i.e., analyses were repeated on only 6 different dates), and hence are uncertain.

(d) The total within-lab percent relative standard deviation includes both the short- and long-term within-lab variation in glass analyses. 
TABLE D.3. Short-Term, Long-Term, and Total Within-Lab \%RSD in As-Analyzed (Unnormalized) ICP Analyses of NBS-SRM-1411 Glass

\begin{tabular}{|c|c|c|c|c|}
\hline $\begin{array}{c}\text { Oxide } \\
\text { Component }\end{array}$ & $\begin{array}{c}\operatorname{Mean}(\mathrm{a}) \\
\mathrm{Wt} \% \\
\end{array}$ & $\begin{array}{c}\text { Short-Term (b) } \\
\text { Within-Lab \%RSD }\end{array}$ & $\begin{array}{c}\text { Long-Term }(c) \\
\text { Within-Lab \%RSD } \\
\end{array}$ & $\begin{array}{c}\text { Total (d) } \\
\text { Within-Lab \%oRSD }\end{array}$ \\
\hline $\mathrm{AI}_{2} \mathrm{O}_{3}$ & 5.63 & 0.48 & 6.28 & 6.30 \\
\hline $\mathrm{B}_{2} \mathrm{O}_{3}$ & 10.65 & 0.94 & 1.51 & 1.78 \\
\hline $\mathrm{BaO}$ & 4.68 & 0.11 & 3.81 & 3.81 \\
\hline $\mathrm{CaO}$ & 2.18 & 1.17 & 4.79 & 4.93 \\
\hline $\mathrm{Fe}_{2} \mathrm{O}_{3}$ & 0.11 & 22.73 & 14.32 & 26.86 \\
\hline $\mathrm{K}_{2} \mathrm{O}$ & 3.90 & 6.54 & 19.91 & 20.96 \\
\hline $\mathrm{MgO}$ & 0.33 & 1.52 & 11.41 & 11.51 \\
\hline $\mathrm{Na}_{2} \mathrm{O}$ & 9.55 & 1.11 & 3.16 & 3.35 \\
\hline $\mathrm{SiO}_{2}$ & 55.64 & 0.58 & 3.19 & 3.24 \\
\hline $\mathrm{TiO}_{2}$ & 0.45 & 35.14 & 34.18 & 49.02 \\
\hline Zno & 3.84 & 0.39 & 1.88 & 1.92 \\
\hline
\end{tabular}

(a) The glass was analyzed for composition two times each on $4 / 1 / 88$ and $5 / 13 / 88$, and once each on $5 / 24 / 88,6 / 8 / 88,7 / 15 / 88$, and $8 / 15 / 88$, for a tota] of eight analyses. The mean weight percent oxides were obtained by computing the mean for each day, and then averaging the values from the six days.

(b) The short-term within-lab percent relative standard deviation quantifies the variation in analyses performed on the same day. The standard deviation of an individual analysis is reported, not the standard deviation of the mean weight percent oxide. Also, note that the shortterm \%RSDs are based on only two degrees of freedom (i.e., duplicate analyses were made on only two dates), and hence are very uncertain.

(c) The long-term within-lab percent relative standard deviation quantifies the variation in analyses performed over the space of a few months. The standard deviation of an individual analysis is reported, not the standard deviation of the mean weight percent oxide. Also, note that the long-term \%RSDs are based on only five degrees of freedom (i.e., analyses were repeated on six different dates), and hence are uncertain.

(d) The total within-lab percent relative standard deviation includes both the short- and long-term within-lab variation in glass analyses. 
TABLE D.4. Short-Term, Long-Term, and Total Within-Lab \%RSD in As-Analyzed (Unnormalized) ICP Analyses of West Valley Glasses DG-WV33, DG-WV34, and DG-WV44

\begin{tabular}{|c|c|c|c|c|c|c|c|c|c|}
\hline \multirow[t]{2}{*}{$\begin{array}{c}\text { Oxide } \\
\text { Component }\end{array}$} & \multicolumn{3}{|c|}{$\begin{array}{c}\operatorname{Meen}^{(a)} \\
W_{t}\end{array}$} & \multicolumn{3}{|c|}{$\begin{array}{c}\text { Short-Term } \\
\text { Within-Lab XRSD } \\
\text { Withe }\end{array}$} & \multicolumn{3}{|c|}{$\begin{array}{l}\text { Long-Term }{ }^{(c)} \\
\text { Within-Lab XRSD }\end{array}$} \\
\hline & DG-WV33 & DG-W $\sqrt{34}$ & DG-WN44 & $06-1 \sqrt{33}$ & DG- $-1 \sqrt{34}$ & $\mathrm{DG}-\mathbf{W} \times 4$ & $0 G-1+\sqrt{33}$ & DG-WN34 & DG-WN44 \\
\hline 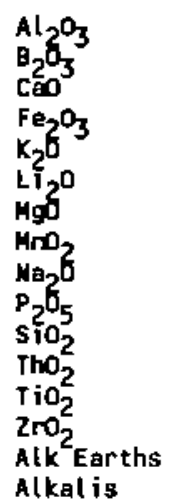 & $\begin{array}{c}8.22 \\
9.09 \\
0.54(e) \\
11.66 \\
4.82 \\
2.63 \\
1.25 \\
1.30 \\
9.78 \\
2.54 \\
40.40 \\
3.34 \\
0.86 \\
0.51 \\
1.87 \text { (e) } \\
17.24\end{array}$ & $\begin{array}{r}5.34 \\
11.14 \\
0.21 \\
9.82 \\
4.84 \\
2.82 \\
0.44 \\
2.00 \\
10.22 \\
2.02 \\
38.54 \\
1.83 \\
2.78 \\
1.89 \\
0.68 \\
17.88\end{array}$ & $\begin{array}{c}8.30 \\
11.30 \\
0.20^{(e)} \\
15.46 \\
4.76 \\
2.80 \\
0.54 \\
0.13 \\
10.33 \\
0.66 \\
37.16 \\
3.56 \\
0.38(\mathrm{e}) \\
1.86 \\
0.74(\mathrm{e}) \\
17.89\end{array}$ & $\begin{array}{l}2.23 \\
0.67 \\
7.86 \\
0.00 \\
1.04 \\
7.97 \\
3.12 \\
0.54 \\
4.19 \\
0.00 \\
1.67 \\
4.55 \\
1.16 \\
7.78 \\
4.54 \\
3.89\end{array}$ & $\begin{array}{l}0.47 \\
0.00 \\
7.21 \\
1.77 \\
4.38 \\
1.67 \\
4.64 \\
1.95 \\
4.32 \\
0.00 \\
1.20 \\
4.40 \\
1.21 \\
5.64 \\
4.74 \\
2.18\end{array}$ & $\begin{array}{r}0.79 \\
1.40 \\
8.11 \\
1.02 \\
13.70 \\
1.82 \\
1.87 \\
3.79 \\
2.23 \\
10.71 \\
0.00 \\
0.20 \\
1.85 \\
5.44 \\
3.42 \\
2.21\end{array}$ & $\begin{array}{r}2.32 \\
2.45 \\
7.10 \\
1.29 \\
15.81 \\
0.00 \\
0.00 \\
2.69 \\
2.84 \\
2.41 \\
1.08 \\
3.94 \\
1.74 \\
0.00 \\
0.00 \\
3.97\end{array}$ & $\begin{array}{r}3.19 \\
2.42 \\
13.65 \\
0.00 \\
15.29 \\
4.40 \\
5.66 \\
0.00 \\
1.46 \\
6.06 \\
1.99 \\
0.00 \\
1.07 \\
3.45 \\
4.39 \\
0.57\end{array}$ & $\begin{array}{r}3.35 \\
2.42 \\
20.99 \\
0.97 \\
12.38 \\
5.47 \\
3.16 \\
0.00 \\
4.85 \\
0.00 \\
4.13 \\
6.10 \\
1.85 \\
7.06 \\
7.20 \\
4.51\end{array}$ \\
\hline
\end{tabular}

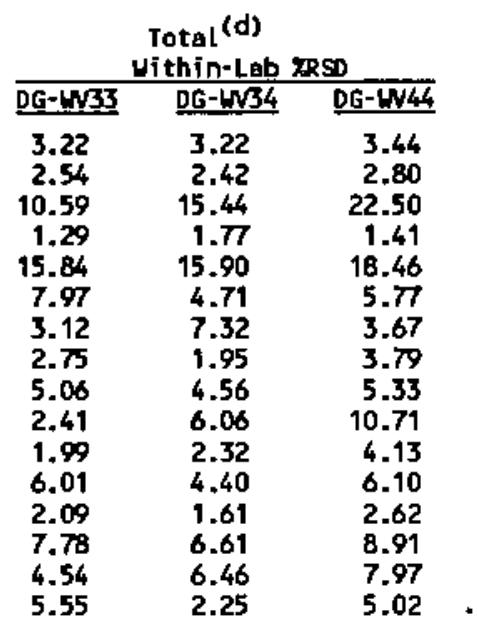

(a) The three glasses were enalyzed for composition two times each on $4 / 1 / 88$ and $5 / 13 / 88$, and once on $6 / 8 / 88$, for a total of five analyses. The mean weight percent oxides are averages of the five values obtained for each oxide.

(b) The short-term within-lab percent relative standard deviation quantifjes the variation in analyses performed on the same day. The standard deviation of an individual analysis is reported, not the stenderd deviation of the mean weight percent oxide. Also, note that the short-term XRSDB are based on only two degrees of freedom (i.e., dupticate analyses were performed on only two dates), and hence are cuite tncertain.

(c) The long-term within-lab percent relative standard deviation quantifies the variation in analyses performed over the space of a few months. The standard deviation of an individual analysis is reported, not the standard deviation of the mean weight percent oxide. Also, note that the Iong-term XRSDs are based on only two degrees of freedom (i.e., analyses were reperted on only three different dates), and hence are quite incertain.

(d) The total within-lab $X$ RSD inctudes both the short- and tong-term within-lab variation in glass analyses.

(e) An outlier was deleted from the data prior to abtaining the mean and standard deviations. 
TABLE D.5. Short-Term, Long-Term, and Total Within-7ab \%RSD of Elemental Boron Releases from Repeated Leachate Analyses of Leachates from 7-Day MCC-3 and 28-Day MCC-1 Leach Tests of West Valley Glasses DG-WV33, DG-WV34, and DG-WV44

I. REPEAT LEACHATE ANALYSES ${ }^{(e)}$

\begin{tabular}{|c|c|c|c|}
\hline \multirow{2}{*}{ Leach Iest } & \multicolumn{3}{|c|}{$\begin{array}{l}\text { Mean Boron Release }{ }^{(a)} \\
\text { pom and (normal ized) }\end{array}$} \\
\hline & DG-LN33 & $D G-W \times 34$ & DG-W/4 \\
\hline $\mathrm{MCC}-3,7$ & $\begin{array}{r}14.51 \\
(0.251)\end{array}$ & $\begin{array}{l}24.15 \\
(0.351)\end{array}$ & $\begin{array}{c}21.30 \\
(0.294)\end{array}$ \\
\hline $\mathbf{m}$ & 4.60 & 6.83 & 6.84 \\
\hline
\end{tabular}

Short-Term
Within-Lab KRSD Within-Lab KRSD

1.46

1.17

$\frac{\mathrm{DG}}{17}$

Long-Term (c)
Within-Lab YRSD
N33 DG-LN34 DG-

$\frac{9-1.64}{7.99}$

$0.46 \quad 0.21 \quad 0.31$

(a) The three leachstes from each test were analyzed for composition two times each on $5 / 16 / 8 B$, and once each on three other dates (appraximately 5/2/88,5/5/88, and $7 / 25 / 88$ for the MCC- 1 leachates and $3 / 19 / 8 B, 5 / 5 / 88$, and $7 / 25 / 8 B$ for the MCC-3 leachates), for total of five analyses per leachate. The mean boron releases were obtained by averaging the two $5 / 16 / 88$ values and then averaging the resulting value with the single values (for each leachate) from the other three days.

(b) The short-term with in-lab percent relative standard deviation quantifies the variation in leachate analyses performed on the same dey. The standard deviation of an individul analysis is reported, not the standard devietion of the mean boron release. Note that the XRSOs apply to boron release in both ppn and normalized units. Also, note that the short-term XRSDS are based on only one degree of freedom ( $i, e .$, computed from two values), and hence ore very uncertain.

(c) The long-term within-lab percent reletive standard deviation quantifies the variation in leachate analyses performed over the space of a fey months. The standerd deviation of an individual snelysis is reported, not the standard deviation of the mean boron release. Note that the KSDs apply to boron release in both pm and normelized units. Also, note thet the long-term XRSDs are based on only three degrees of freedom (data from four times were used), and hence are incertain.

(d) The total within-lab percent relative standard deviation includes both the short- and long-term within-lab variation in leachate analyses.

(e) The XRSDs in this table are based on repeated leachate analyses of leachate from a single leach test for each of the glass and leach test combinetions. Hence, the ZRSDs contain veriation only from the leachete analysis process, and not from the leach testing process. 
TABLE D.6. Short-Term, Long-Term, and Total Within-Lab \%RSD of Elemental Boron Releases from Repeated 7-Day MCC-3 and 28-Day MCC-1 Leach Tests of West Valley Glasses DG-WV33, DG-WV34, and DG-WV44

II. REPEAT LEACH TESTS

\begin{tabular}{|c|c|c|c|c|c|c|c|c|c|c|c|c|}
\hline \multirow[t]{2}{*}{ Leach Test } & \multicolumn{3}{|c|}{$\begin{array}{l}\text { Meen Boron Release }{ }^{(a)} \\
\text { pom and (normal ized) }\end{array}$} & \multicolumn{3}{|c|}{$\begin{array}{l}\text { Short-Term }{ }^{(b)} \\
\text { within-Lab XRSD }\end{array}$} & \multicolumn{3}{|c|}{$\begin{array}{c}\text { Long-Term }{ }^{(c)} \\
\text { Within-Lab XRSD }\end{array}$} & \multicolumn{3}{|c|}{$\begin{array}{c}\text { Total (d) } \\
\text { Within-Lob XRSD }\end{array}$} \\
\hline & DG-1N33 & $\mathrm{DG}-1 \mathrm{N34}$ & DG-WV44 & DG-W133 & $D G-W \sqrt{34}$ & DG-WV44 & $D G-W \sqrt{33}$ & DG-WN34 & DG-WW4 & $D G-1 \sqrt{33}$ & $D G-W \sqrt{34}$ & DG-WN4 \\
\hline MCL-3, 7-day & $\begin{array}{c}12.72 \\
(0.220)\end{array}$ & $\begin{array}{c}23.53 \\
(0.342)\end{array}$ & $\begin{array}{l}21.52 \\
(0.297)\end{array}$ & 0.72 & 1.59 & 1.79 & 6.02 & 6.16 & 7.28 & 6.06 & 6.37 & 7.50 \\
\hline MCC-1, 28-day & $\begin{array}{c}4.64 \\
(16.07)\end{array}$ & $\begin{array}{c}6.92 \\
(20.11)\end{array}$ & $\begin{array}{l}6.71 \\
(18.56)\end{array}$ & 3.68 & 2.98 & 3.05 & 4.02 & 4.63 & 6.66 & 5.45 & 5.51 & 7.33 \\
\hline
\end{tabular}

(a) The two leach tests (for each of the three glasses) were performed starting at three different times. At each of the three times, the tests were run in duplicate. Hence, there were a total of six runs for each olass and leach test combination. The three different times each test was performed mere approximately equally spaced over a three month periad. The mean boron releases were obtained by averaging the six boron release values for each glass and leach test conbination.

(b) The short-term within-lob percent relative standard deviation quantifies the variation in teach tests performed at the same time and in leachate analyses performed on the same day. The standard deviation of an individual analysis is reported, not the standerd deviation of the meen boron release. Note that the XRSDs apply to boron release in both ppm and normalized units. Also, note that the short-term zRSDs are based on only three degrees of freedom (i.e., the tests were performed in duplicate three times), and hence ore quite uncertain.

(c) The long-term within-lab percent relative standard deviation quantifies the variation in leach tests and leachate analyses performed over the space of a few months. The standard deviation of an individual boron release is reported, not the standard deviation of the mean boron release. Note thet the XRSDs apply to borcon release in both

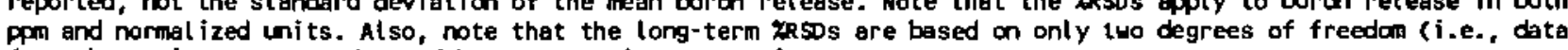
from three times were used), and hence are quite uncertain.

(d) The total within-lab percent relative standerd deviation includes both the short- and long-term within-lab variation in the leach testing and leachate analysis processes. 
. 


\section{DISTRIBUTION}

No. of

Copies

\section{OFFSITE}

10 DOE/Office of Scientific and Technical Information

4 DOE Office of Civilian Radioactive Waste Management Forrestal Building

Washington, DC 20585

ATTN: L. H. Barrett, RW-33

S. H. Kale, RW-20

D. E. Shelor, RW-32

R. Stein, RW-23

2 OOE Office of Defense Waste \& Transportation Management GTN Washington, DC 20545

ATTN: K. A. Chacey, DP-123

T. B. Hindman, DP-12

4 DOE Office of Remedial Action GTN

\& Waste Technology

Washington, DC 20545

ATTN: J. E. Baublitz, NE-20

J. A. Coleman, NE-24

T. W. McIntosh, NE-24

H. F. Walter, NE-24

\section{A. T. Clark}

Division of FueT Material Safety Nuclear Regulatory Commission Washington, DC 20555

V. Stello

Office for the Executive

Director for Operations

Mail Station 6209

Nuclear Regulatory Commission

Washington, DC 20555
No. of

Copies

Sheldon Meyers

Environmental Protection Agency

Office of Radiation Programs (ANR-458)

401 M Street S.W.

Washington, DC 20460

J. M. McGough

DOE Albuquerque Operations Office

P.0. Box 5400

Albuquerque, NM 87185

P. G. Hagan

Joint Integration Office

Carimont Executive 1

4308 Carlisle N.E.

Suite 101

Albuquerque, NM 87107

E. Maestas

DOE West Valley Project

P.0. Box 191

West Valley, NY 14171

3 DOE Idaho Operations Office

550 Second Street

Idaho Falls, ID 83401

ATTN: M. W. Shupe

J. P. Hamric

C. R. Enos

F. T. Fong

DOE San Francisco Operations

1333 Broadway

Oakland, CA 94612

M. R. Jugan

DOE Oak Ridge Operations Office P.0. Box E

Oak Ridge, TN 37830

H. T. Goldston

DOE Savannah River Operations Office

P.0. Box A

Aiken, SC 29801 
No. of

Copies

M. J. Steindler

Argonne National Laboratory

9700 South Cass Avenue

Argonne, IL 60439

C. S. Abrams

Argonne National Laboratory

P.0. Box 2528

Idaho Falls, ID 83401

3 Battelle Memorial Institute

Project Management Division

505 King Avenue

Columbus, $\mathrm{OH} 43201$

ATTN: W. A. Carbeiner

R. A. Nathan

Technical Library

L. D. Ramspott

Lawrence Livermore National Laboratory

University of California

P.0. Box 808

Livermore, CA 94550

D. T. Oakley, MS 619

Los Alamos Scientific Laboratory P.0. Box 1663

Los Alamos, NM 87544

4 Oak Ridge National Laboratory

P.0. Box $Y$

Oak Ridge, TN 37830

ATTN: W. D. Burch

R. T. Jubin

L. J. Mezga

D. W. Turner

2 Sandia Laboratories

P.0. Box 5800

Albuquerque, NM 87185

ATTN: R. W. Lynch

Technical Library
No. of

Copies

J. R. Berreth

Westinghouse Idaho Nuclear

Co., Inc.

P.0. Box 4000

Idaho Falls, ID 83401

6 E. I. du Pont de Nemours Company

Savannah River Laboratory

Aiken, SC 29801

ATTN: R. G. Baxter

M. D. Boersma

J. G. Glasscock

J. R. Knight

M. J. Plodinec

C. T. Randall

A. D. Rodgers

Mail Stop 2411

EG\&G Idaho

P.0. Box 1625

Idaho Falls, ID 83415

R. Shaw

Electric Power Research Institute

3412 Hillview Avenue

P.0. Box 10412

Palo Alto, CA 94303

5 West Valley Nuclear Services Company

P.0. Box 191

West Valley, NY 14171

ATTN: S. M. Barnes

R. R. Borisch

R. A. Humphrey

J. M. Pope

R. A. Thomas

J. L. White, Chairman

Energy Research \& Development Authority

Empire State Plaza

ATbany, NY 12223 
No. of

Copies

ONSITE

6 DOE Richland Operations office
R. W. Brown
C. E. Collantes
M. J. Furman
R. E. Gerton
P. E. Lamont
E. C. Norman

8 Westinghouse Hanford Company

J. M. Henderson

T. L. Jones

R. E. Lerch

H. E. McGuire

J. L. Scott

D. A. Turner

D. D. Wodrich

B. A. Wolfe

40 Pacific Northwest Laboratory

C. R. Allen

W. W. Ballard, Jr.

S. 0. Bates
No. of

Copies

Pacific Northwest Laboratory (contd)

L. A. Bray

R. L. Bunnell

H. C. Burkholder

c. C. Chapman

T. T. Claudson

R. E. Einziger

T. L. GiTbride

R. W. Goles

W. 0 . Heath

L. K. Holton

W. L. Kuhn

J. L. McElroy

G. B. Mellinger

J. M. Perez

M. E. Peterson

G. F. Piepel

M. A. Reimus (10)

P. W. Reimus

W. A. Ross

J. M. Seay

S. C. Slate

J. H. Westsik, Jr.

Publishing Coordination

Technical Report Files (5) 
1 